\title{
National parliaments in the aftermath of the Lisbon Treaty : adaptation to the 'New Opportunity Structure'
}

Citation for published version (APA):

Strelkov, A. (2015). National parliaments in the aftermath of the Lisbon Treaty : adaptation to the 'New Opportunity Structure'. [Doctoral Thesis, Maastricht University]. Datawyse / Universitaire Pers Maastricht. https://doi.org/10.26481/dis.20150212as

Document status and date:

Published: 01/01/2015

DOI:

10.26481/dis.20150212as

Document Version:

Publisher's PDF, also known as Version of record

\section{Please check the document version of this publication:}

- A submitted manuscript is the version of the article upon submission and before peer-review. There can be important differences between the submitted version and the official published version of record. People interested in the research are advised to contact the author for the final version of the publication, or visit the DOI to the publisher's website.

- The final author version and the galley proof are versions of the publication after peer review.

- The final published version features the final layout of the paper including the volume, issue and page numbers.

Link to publication

\footnotetext{
General rights rights.

- You may freely distribute the URL identifying the publication in the public portal. please follow below link for the End User Agreement:

www.umlib.nl/taverne-license

Take down policy

If you believe that this document breaches copyright please contact us at:

repository@maastrichtuniversity.nl

providing details and we will investigate your claim.
}

Copyright and moral rights for the publications made accessible in the public portal are retained by the authors and/or other copyright owners and it is a condition of accessing publications that users recognise and abide by the legal requirements associated with these

- Users may download and print one copy of any publication from the public portal for the purpose of private study or research.

- You may not further distribute the material or use it for any profit-making activity or commercial gain

If the publication is distributed under the terms of Article $25 \mathrm{fa}$ of the Dutch Copyright Act, indicated by the "Taverne" license above, 


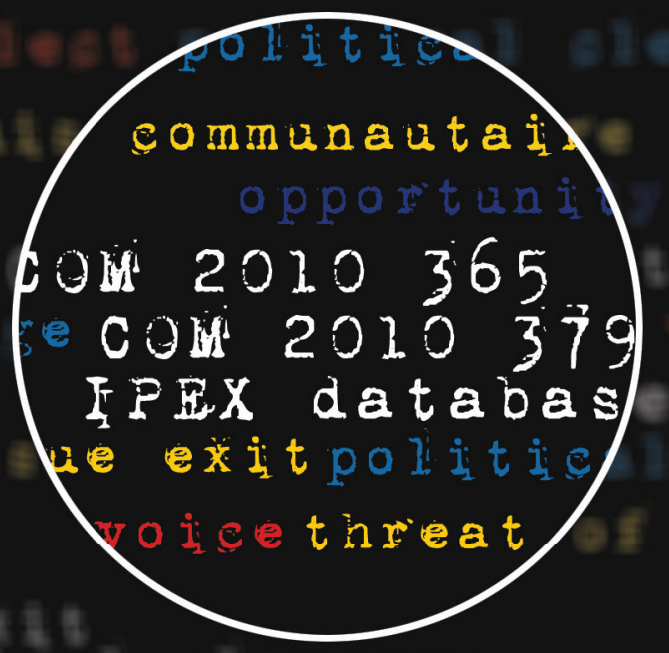

\section{NATIONAL PARLLAMENTS IN THE AFTERMATH OF THE LISBON TREATY ADAPTATION TO THE 'NEWOPPORTUNTTYSTRUGCUUE'}


(C) Copyright Alexander Strelkov, Maastricht 2015

ISBN 9789461594044

Omslag ontworpen door Jean Scheijen 


\title{
National Parliaments in the Aftermath of the Lisbon Treaty
}

Adaptation to the 'New Opportunity Structure'

\author{
PROEFSCHRIFT
}

ter verkrijging van de graad van doctor aan de Universiteit Maastricht, op gezag van de Rector Magnificus, Prof dr. L.L.G.Soete, volgens het besluit van het College van Decanen, in het openbaar te verdedigen op donderdag 12 februari 2015 om 16:00 uur

door

Alexander Strelkov

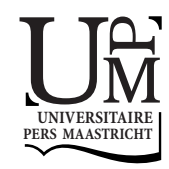




\section{Promotores}

Prof.dr. Tannelie Blom

Prof.dr. Christine Neuhold

\section{Beoordelingscommissie}

Prof.dr. Sophie Vanhoonacker (voorzitter)

Prof.dr.Thomas Christiansen

Prof.dr. Johannes Pollak, Institute for Advanced Studies, Vienna

Prof. Michael Shackleton

Prof.dr. Wolfgang Wessels, University of Cologne 


\section{Contents}

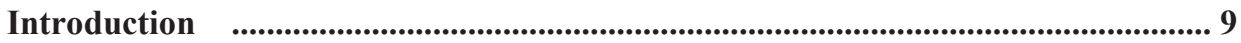

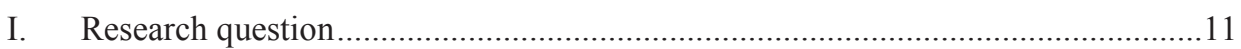

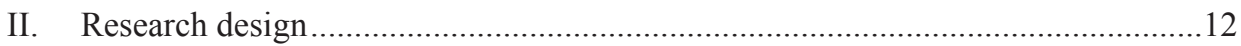

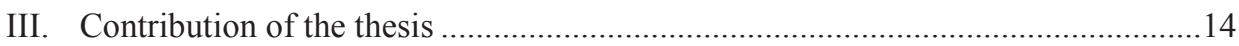

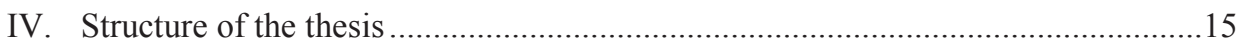

\section{CHAPTER 1: Review of the literature on parliamentary scrutiny of EU}

affairs

1.1 Evolution of the academic literature on the role of national parliaments in

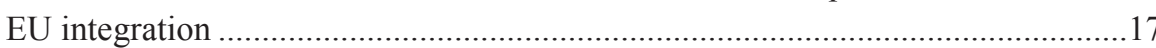

1.2 Key strands of the literature on the role of national parliaments in EU integration.

1.3 The shortcomings of the academic literature on the role of national

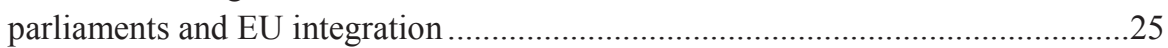

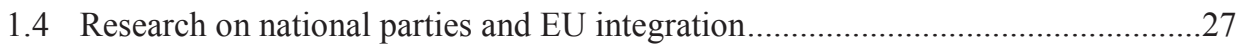

1.5 Contribution of the dissertation to the field of EU studies .....................................29

CHAPTER 2: Concepts, theories and methods .................................................................31

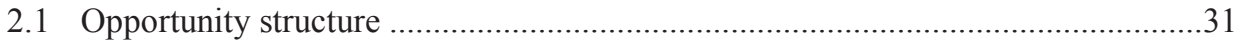

2.2 Types of actor reactions to the new opportunity structure..........................................33

2.3 The concepts of 'party cartel' and 'EU political cleavage' .......................................35

2.4 Parliamentary scrutiny, political influence and parliamentary strength ...................37

2.5 Expectations about behaviour of parliamentary actors in the new

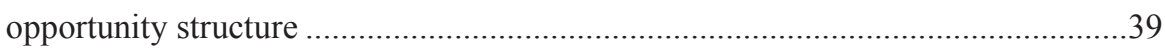

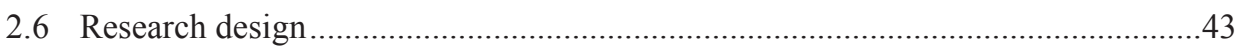

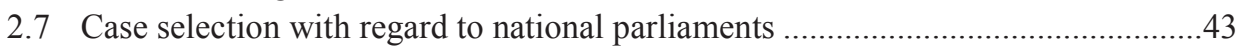

2.8 Case selection with regard to EU proposals ........................................................47

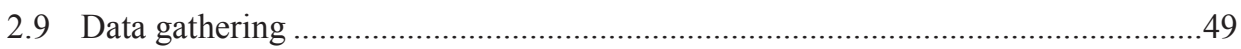

2.10 Data interpretation through process-tracing .........................................................52

2.11 Limitations and challenges of the research design .................................................54

CHAPTER 3: The evolution of the role of national parliaments in the process of EU integration .........................................................................57

3.1 National parliaments and European EU integration before the Maastricht Treaty . 
3.2 National parliaments and EU integration in the aftermath of the Maastricht

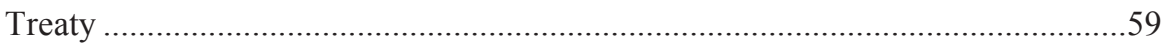

3.3 The provisions of the Lisbon Treaty on national parliaments

\section{CHAPTER 4: National and EU policies in the domains of pension provision} and low-skilled labour migration .....................................................65

4.1 The context of EU involvement in pensions policy ............................................65

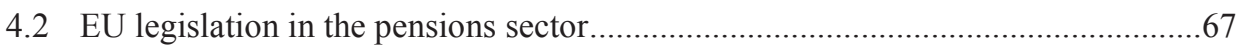

4.3 Overview of the Green Paper towards adequate, sustainable and safe European pension systems..........................................................................68

4.4 Overview of the White Paper "Agenda for adequate, safe and sustainable

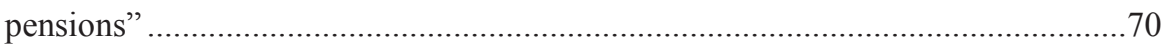

4.5 Pension policy in Sweden.................................................................................. 71

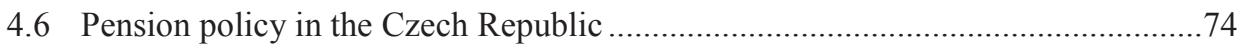

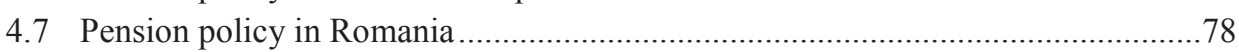

4.8 The evolution of EU competences in the field of low-skilled labour

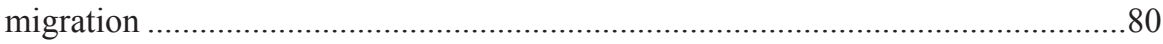

4.9 Overview of the Proposal for a directive on seasonal labour migrants .................82

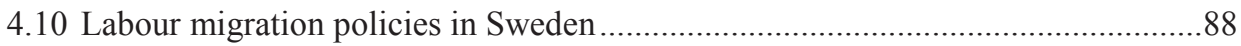

4.11 Labour migration policies in the Czech Republic ..............................................92

4.12 Labour migration policies in Romania ............................................................93

CHAPTER 5: Parliamentary scrutiny of EU affairs in the Swedish Riksdag ........95

5.1 Evaluation of EU proposals on pensions and labour migration policies in

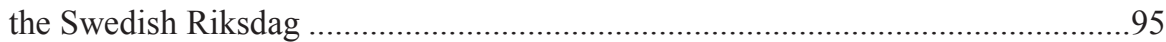

5.2 Domestic rules of procedure, material and temporal constraints..........................97

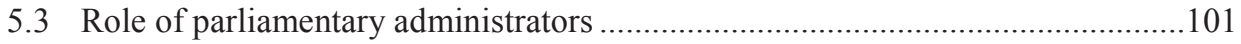

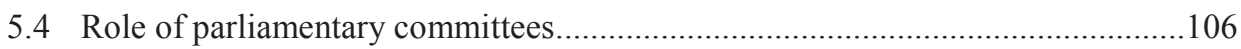

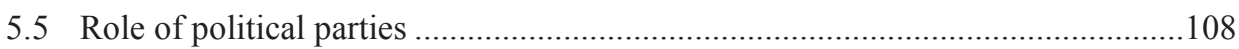

5.6 Evaluation of Swedish parliamentary practice .................................................. 114

CHAPTER 6: Parliamentary scrutiny of EU affairs in the Czech Parliament.....119

6.1 Evaluation of EU proposals on pensions and labour migration policies in the Czech Parliament...................................................................................... 119

6.2 Domestic rules of procedure, material and temporal constraints.......................... 124

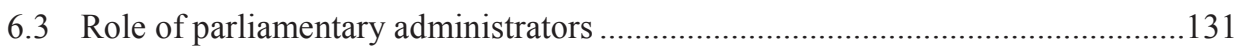

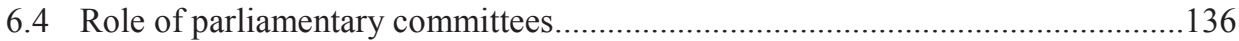

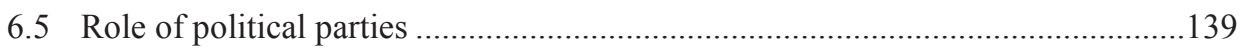

6.6 Evaluation of the Czech parliamentary practice ................................................ 146 


\section{CHAPTER 7: Parliamentary scrutiny of EU affairs in the Romanian}

Parliament

7.1 Evaluation of EU proposals on pensions and labour migration policies in the Romanian parliament................................................................................149

7.2 Domestic rules of procedure, material and temporal constraints..........................151

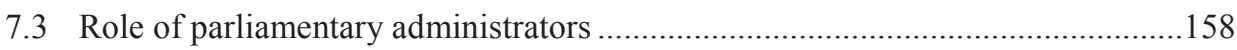

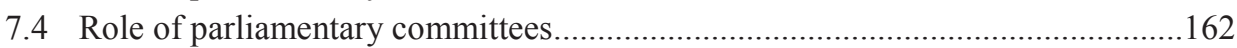

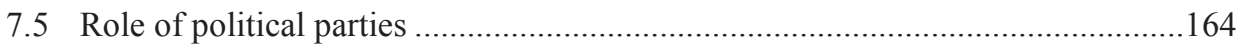

7.6 Evaluation of Romanian parliamentary practice ............................................... 167

CHAPTER 8: Analysis of the adaptation of national parliaments to the Lisbon Treaty .............................................................................171

8.1 Domestic rules of procedure, material and temporal constraints.........................173

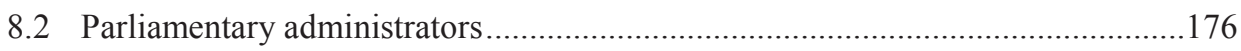

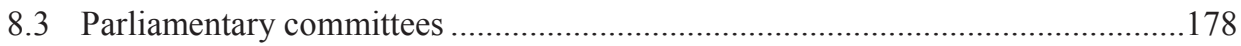

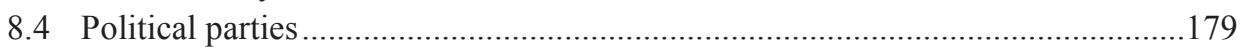

8.5 Reactions of parliamentary actors to the new opportunity structure .....................183

8.6 Explaining the behaviour of political parties through party cartel thesis and

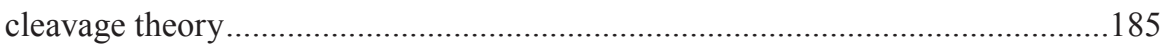

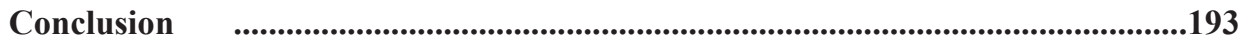

I. Factors affecting the use of the new opportunity structure ................................193

II. Expectations about the behaviour of parliamentary actors in the new opportunity structure

III. Typology of reactions by parliamentary actors to the new opportunity structure

IV. Expectations about the causes of neglect of the content of EU proposals by

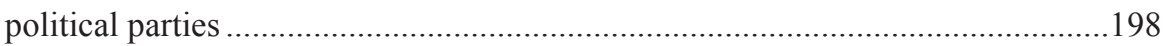

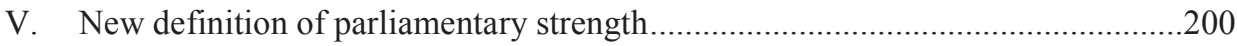

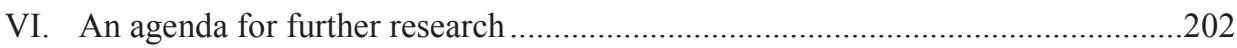

Bibliography ......................................................................................................................207

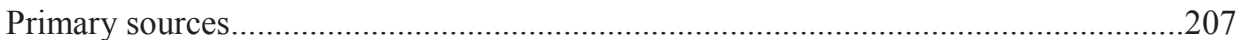

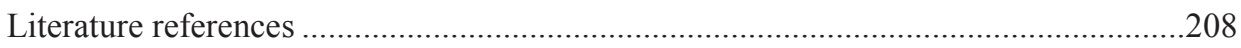


ANNEX 1: List of respondents........................................................................................227

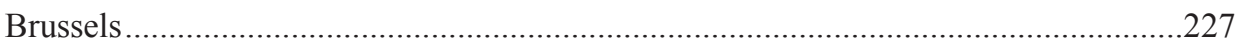

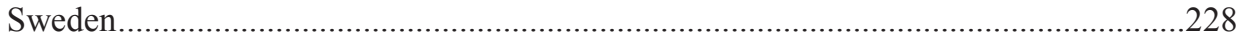

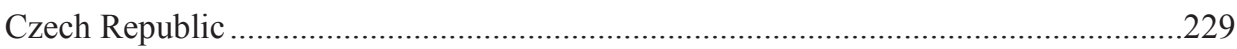

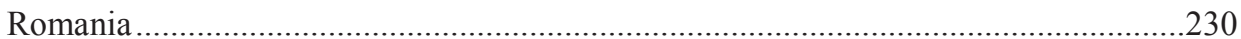

ANNEX 2: Questionnaire templates..............................................................................231

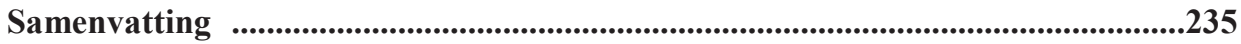

Valorization addendum ..................................................................................................237

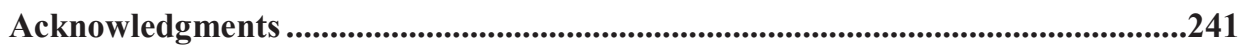

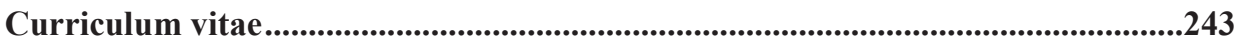




\section{Introduction}

The Lisbon Treaty marks a nodal point in the history of European Union (EU) integration. New structures have been created, such as the posts of the President of the European Council and the High Representative of the Union for Foreign Affairs and Security Policy. The competences of EU institutions have been enhanced, as in the case of the European Parliament, which can now play an even greater role in EU policy-making due to the extension of the Ordinary Legislative Procedure (OLP). All these changes have been carried out in order to achieve the goals of the so-called Laeken Declaration by the EU Heads of State and Government (European Council 2001, pp.18-26), to make the EU more transparent, democratic and efficient.

At the same time, however, the evolution of the European Union cannot be reduced to Treaty change and the development of EU institutions. European integration profoundly influences the functioning of domestic political structures, such as national executives, constitutional courts and diplomatic services. National parliaments have also been affected by the EU, although this process has contributed to what Andersen and Eliassen (1996) call 'systematic erosion' of the role of national parliaments ${ }^{1}$. Several factors - the spread of qualified-majority voting (QMV), direct elections to the European Parliament and the growing complexity of negotiations within the EU - mean that national parliaments have found it increasingly difficult to scrutinize and control the policies of their respective governments in the EU political arena. This has led a number of academics (Moravcsik 1994, Maurer and Wessels 2001) to conclude that national parliaments are largely incapable of effectively adapting to the challenges of European integration.

Nonetheless, both EU officials ${ }^{2}$ and experts (Bausili 2002, p.16; Jans and Piedrafita 2009, pp.19-20; Christiansen, Högenauer and Neuhold 2014) believe that the latest constitutional reform in the EU by way of the Lisbon Treaty can turn national parliaments into active participants in the EU policymaking process. For the first time in the history of European integration national parliaments can have a direct impact on policymaking at the EU level. In fact, one of the new procedures, the Early Warning System (EWS), which allows national parliaments to block EU legislation on the grounds of

\footnotetext{
${ }^{1}$ For an excellent overview of the debate on the 'decline of parliaments' see Costa, Kerrouche and Magnette (2004); and Blondel (1974). For counter arguments to the 'parliamentary decline' thesis see Elgie and Stapleton (2006), Kelso (2007), Flinders and Kelso (2011).

${ }^{2}$ See, for example, the speech by J. Buzek at the University of Strasbourg, 8 March 2011 (http://www.sitepres.europarl.europa.eu/president/en/press/speeches/sp-2011/sp-2011-March/speeches-2011-March-

4.html); Buzek (2011); Interview of M. Wallström in Euractiv, 9 September 2009 (http://www.euractiv.com/priorities/wallstroem-mulls-exit-strategy-e-news-222527); Speech by Maros Sefcovic of 22 October 2010 on the role of national parliaments after the Lisbon Treaty (http://europa.eu/rapid/pressrelease_SPEECH-10-584_en.htm).
} 
noncompliance with the principle of subsidiarity $^{3}$, has already forced the European Commission to withdraw a controversial proposal, the so-called Monti II regulation ${ }^{4}$, and triggered a debate about the regulation establishing the European Public Prosecutor's Office ${ }^{5}$.

All these changes mean that with the entry into force of the Lisbon Treaty a new political environment has been created for national parliaments. This environment will be considered under the analytical category of the 'opportunity structure'. An 'opportunity structure' can be defined as "various types of channels of access to the public sphere and to the policy-making and implementation processes (Nentwich 1996, p.2) ${ }^{6}$. The concept implies that the 'room for manoeuvre' for national parliaments increases as they acquire new competences and formal mechanisms of influence. The concept of the opportunity structure not only addresses the adoption of new formal rules and procedures. It also implies that the relationship among parliamentary actors can be redressed because the distribution of resources and competences is altered, putting some types of actors in a privileged position in relation to others.

In the case of a national parliament, the transformation of the opportunity structure affects existing relations between key types of parliamentary actors, such as committees, political parties and parliamentary administrators. Strøm (in Döring 1995, p.64) argues that committees and political parties are the crucial element of a parliament's organization. However, Olson (in Shaw 1998, p.228) argues that "parties and committees... are contradictory and even mutually exclusive means of internal organization [in a legislature]. The importance of each is inversely proportional to the other. The importance of committees can go to the detriment of the role that political parties play (and vice versa)". In contrast to the US Congress, national legislatures in Europe have been described as parliaments with weak committees and strong parties (Damgaard in Döring 1995, pp.308-309; Shaw 1998, p.227). In other words, the logic of committee work is often framed by partisan interests while the chances of developing a distinct committee identity (as opposed to a partisan identity) are slim. Nonetheless, few studies, the work of Bellamy and Kröger (2014) being one notable exception, have attempted to take into account the role of political parties in analysing the impact of EU integration on national parliaments. Most studies have predominantly focused on the role of European Affairs Committees (EACs). It has not been comprehensively taken into account, however, that the behaviour of EACs can be affected by different partisan compositions during vari-

\footnotetext{
${ }^{3}$ Within the framework of the Early Warning System, national parliaments can issue so-called 'yellow cards' and 'orange cards' against EU policy proposals. The procedure will be addressed in Chapter 3

${ }^{4}$ Brussels drops plans for EU law limiting right to strike // EurActiv. 14 September 2012

${ }^{5}$ National democracy pushing back: European Commission shown its second 'yellow card' // OpenEurope blog. 29 October 2013;Commission's dismissal of national parliaments' concerns over EPPO shows why a red card is needed // OpenEurope blog. 28 November 2013; COM (2013) 0851.

${ }^{6}$ To a large extent the opportunity structure concept, which underlines the ability of political actors to choose the various 'arenas' to best pursue their interests, is similar to 'venue shopping'. For example, see Guiraudon V. (2000).
} 
ous parliamentary terms, the saliency of EU issues in inter-party debates and the electoral benefits that a parliamentarian can obtain from committee membership. Moreover, while EACs have received a lot of scholarly attention, the role of sectoral committees in dealing with EU affairs remains less clear (Christiansen et al. 2014, p.6; Kropp, Buche and Buzogány 2011, pp.228-229).

Given that one of the key tasks of parliamentary committees is securing information and expertise (for example, Krehbiel 1991), it can be argued that the role of parliamentary administrators should also be taken into account when considering the functioning of the scrutiny process. Parliamentary administrators draft policy documents and provide advice, which might affect the content of decisions taken by members of parliament (MPs) (Egeberg et al. 2013, p.496). Bearing in mind that the Lisbon Treaty has increased the access of national parliaments to EU documentation, it could be argued that without the support of parliamentary staff, EACs would not be able to make an effective selection of EU proposals to receive further scrutiny. Ultimately, the behaviour of committees, parliamentary administrators and political parties has to be taken into account in order to fully understand the functioning of parliamentary scrutiny of EU affairs. However, there is almost no research that investigates how the behaviour of these parliamentary actors is being transformed in the post-Lisbon environment. At the same time, previous research (Bergman 1997, Saalfeld 2005 and Raunio 2005b) has shown that attitudes to European integration can have an important effect on the development of parliamentary scrutiny of EU affairs ${ }^{7}$.

\section{Research question}

The abovementioned observations on the impact of EU integration on national parliaments as well as on different types and behaviour patterns of parliamentary actors lead to the research question of the dissertation: Which factors determine the use national parliaments make of the 'new opportunity structure'? This gives rise to a number of related sub-questions:

1. What is the focus of national parliamentary scrutiny of EU affairs under the new opportunity structure? The first sub-question addresses the rationale of the scrutiny process. Many of the tools acquired by national parliaments in the aftermath of the Lisbon Treaty can be considered 'restrictive', as they are meant to keep the spread of EU competences in check. Hence, the scrutiny process primarily addresses the division of 'spheres of influence' between EU and national institutions. On the other hand, parliaments can 'interpret' the Lisbon Treaty provisions in order to focus more on domestic executive-legislative relations or use the EU's proposals to address the content of certain national public policies.

\footnotetext{
${ }^{7}$ I will consider this issue under the title of "political cleavage" in Chapter 2
} 
2. Are some parliamentary actors more prone to use the new opportunity structure than others; and, if so, why? How has the relationship between parliamentary committees, parliamentary staff and political parties developed in the aftermath of the Lisbon Treaty? Greater cooperation might be expected between EACs and standing committees in order to exchange expertise and provide timely analysis of EU proposals, which also creates the conditions for parliamentary committees to become more independent of partisan influence. Parliamentary administrators could use the new political environment to acquire greater leverage over the outcomes of the scrutiny process (Högenauer and Neuhold 2013, p.5-6). Their role in selecting documents for scrutiny and providing analysis of EU proposals could shape not only the parliamentary agenda but also the views of MPs. Moreover, although mainstream centre-left and centre-right political parties have traditionally kept a low profile on EU affairs (Raunio 2009; Auel and Raunio 2011), the new opportunity structure might lead to the fact that all or certain parliamentary parties adopt a more active role in addressing these topics. This could be explained by the fact that national parliaments obtain instruments which allow scrutiny of EU proposals that directly affect parties' policy preferences.

3. Have national parliaments become more "independent" of their respective governments in the domain of EU affairs? Drawing on Maurer and Wessels (2001, pp.69-72) it could be argued that the ability to acquire and process information irrespective of a government's involvement is the crucial factor in a parliament's independence from the domestic executive. In the aftermath of the Lisbon Treaty, national parliaments obtained direct access to EU documentation, but it remains unclear whether they can analyse it without the help of their domestic executives. In order to do this, parliaments would need to invest in developing their analytical support structures.

\section{Research design}

To address these research questions, the dissertation adopts an inductive research design based on qualitative case studies ${ }^{8}$. Although the focus of the dissertation is inductive, the concepts used within the thesis help structure empirical data and frame the analysis. The research design addresses the challenges of external validity by selecting cases which are representative of different parliamentary traditions and by assessing the evolution of parliamentary scrutiny of EU affairs over several years. External validity of the research findings was addressed by using 'diverse' case selection strategy (Gerring 2007; Seawright and Gerring 2008; Rohlfing 2012) ${ }^{9}$. Internal validity is achieved by

\footnotetext{
${ }^{8}$ Although this dissertation analyzes a number of expectations about the behaviour of parliamentary actors, they are not derived from a distinct theory but are based on observations from academic literature. Given the fact that this dissertation is not engaged in explicit theory-testing, I consider the research design of the study to be inductive

${ }^{9}$ See Chapter 2 for the discussion of potential case selection strategies, including 'most similar' and 'most different' approaches
} 
crosschecking different sources of information - the interview data, primary sources and secondary literature - for any inconsistencies and contradictions ${ }^{10}$.

The dissertation analyses the evolution of scrutiny practices in the parliaments of Sweden, the Czech Republic and Romania. These parliaments were selected on the basis of typologies developed by Karlas (2011), Winzen (2013) and Magone (2011, pp.201-204), who consider 'parliamentary strength' in domestic politics as one of the key factors determining parliamentary leverage in EU affairs ${ }^{11}$. In addition the index of parliaments' budgetary powers (Wehner 2006) was used as a proxy for their leverage in domestic politics. Sweden, Czech Republic and Romania represent strong, mediumstrong and weak parliaments respectively. The thesis focuses on parliamentary debates about the 'Green Paper towards an adequate, sustainable and safe European pension system' (COM 2010 0365) and the 'Proposal for a directive on the conditions of entry and residence of third country nationals for the purpose of seasonal employment' (COM 20100379 final). From the information obtained from 12 exploratory interviews with the representatives of national parliaments in Brussels in October to December 2010, and from the IPEX database ${ }^{12}$, these EU proposals were identified as having the potential to affect domestic electoral politics ${ }^{13}$. It does after all depend on the political will of MPs to activate the Lisbon provisions. EU proposals related to pensions and labour migration are seen to provide additional incentives for MPs to address EU issues in parliamentary debates. These proposals are also rather technical, potentially allowing parliamentary administrators to shape the course of the scrutiny process (DeGregorio 1994; Baekgaard, Blom-Hansen and Serritzlew 2014).

Information on the scrutiny process was gathered in open-ended, semi-structured expert and elite interviews. In addition, various primary sources were used, such as the documents of EU institutions and bodies, the rules of procedure and resolutions of national parliamentary committees, draft national legislation dealing with the scrutiny of EU affairs, national constitutional acts and the rulings of constitutional courts. In total, 165 semi-structured interviews ${ }^{14}$ were conducted with 140 respondents, primarily within the time periods October to November 2010, September to December 2011, March to May 2012, May 2013 and October to November 2013 (see Annex 1) ${ }^{15}$. Notes were

\footnotetext{
${ }^{10}$ For example, opinions of MPs from both governing and opposition parties were taken into account. Moreover, the actors' assessment of specific documents, for example the Romanian law on executive-legislative cooperation in EU affairs, was consistently compared to the text of the primary sources.

${ }^{11}$ See Chapter 2 for alternative views about using a parliament's influence in domestic politics to determine its leverage in EU affairs.

${ }^{12}$ IPEX is an inter-parliamentary database dedicated to the scrutiny of EU documents

${ }^{13}$ Representatives of national parliaments in Brussels also mentioned various parliamentary debates on the measures taken by the EU to tackle both financial and economic crises. However, the respondents doubted the extent to which these discussions could be used by MPs in electoral competition and whether the technical details were comprehensible to the general voter.

${ }^{14}$ All the interviews were conducted on the condition that the respondents remain anonymous and their personal details are not disclosed in any way.

${ }^{15}$ An average interview lasted around 45 minutes, the shortest being 15 minutes, the longest nearly two hours
} 
taken during the interviews and, when respondents agreed, the interviews were recorded. The following groups of respondents were included in the research:

- staff members of the European Commission and the European Parliament (EP); responsible for the policy areas outlined above and cooperation with national parliaments;

- Members of the European Parliament (MEPs) and national parliaments (MPs);

- parliamentary administrators (for example, assistants to MEPs, staff members of national parliamentary committees ${ }^{16}$ or the parliamentary administration);

- representatives of EU-level stakeholders (for example, BusinessEurope, ETUC, PICUM) and national stakeholders (such as trade unions or business associations);

- national and EU-level experts ${ }^{17}$;

- journalists with key national newspapers of the selected Member States.

The information obtained from the interviews and primary sources was analysed using process-tracing, an approach that explains social phenomena by assessing the causal links between the stages and critical junctures of a social process (George and Benett 2005 , p.6). The dissertation engages in tracing the scrutiny process of EU proposals. The key formal decision-making points are established, for example, the development of a background document, the adoption of committee or plenary resolutions or a change in parliamentary rules of procedure. The involvement of parliamentary actors (administrators, committees and parties) at various phases was taken into account, as well as any change in their input or leverage at the different stages of parliamentary scrutiny.

\section{Contribution of the thesis}

On the basis of analysing new interview data, the dissertation makes a number of contributions to the study of national parliaments and EU integration. First, in contrast to the longstanding tradition of focusing on formal rules of parliamentary scrutiny of EU affairs, the thesis addresses their practical implementation and the 'micro-level' of the scrutiny process (Kropp, Buche and Buzogany 2011, pp.228-230), as well as the routines and practice of discussing EU issues at the level of parliamentary committees.

Second, the thesis takes account of the adaptation of parliamentary institutions in Central and Eastern Europe (CEE) to European integration. According to Holzhacker (2008, p.152), most studies dealing with the role of national parliaments in the EU have concentrated on the 'usual suspects' - the parliaments of the West European member states. Assessing parliamentary structures in both 'old' and 'new' member states provides a better understanding of the evolution of national parliamentary institutions in the process of EU integration

\footnotetext{
${ }^{16}$ Primarily of the EACs.

${ }^{17}$ Experts either dealing with a specific policy area or specializing in domestic politics in general.
} 
Third, previous studies of the adaptation of national parliaments to EU integration have not fully taken account of the involvement of political parties (Goetz and Meyer-Sahling 2008, p.12; Green-Pedersen 2010, p.361) or of parliamentary administrators. This is a major handicap, as it eclipses the behaviour of actors that can contribute to shaping the outcome of the scrutiny process. In order to address this shortcoming, the thesis analyses the behaviour of all types of parliamentary actors, from administrators to parliamentary parties and committees, that can influence the scrutiny of EU affairs.

\section{Structure of the thesis}

Chapter 1 provides an overview of the academic literature on national parliaments. In addition to identifying key research areas, the chapter demonstrates how the current study addresses the shortcomings and new trends in the contemporary academic literature on EU integration and national parliaments. Chapter 2 addresses the key concepts of opportunity structure, 'voice', 'threat of issue exit' and 'neglect', and develops a number of expectations about the behaviour of different types of parliamentary actors in the post-Lisbon environment. It also probes into a number of concepts from comparative politics - 'party cartel' and 'political cleavage' - that might help to explain why parliamentary actors choose to adopt a particular type of behaviour during the scrutiny of EU affairs. In addition, the chapter explores the research methods used within the thesis, that is, process-tracing as well as elite and expert interviewing. Detailed information is provided on case selection, the choice of respondents and interview sampling. The techniques and challenges of crosschecking information obtained from interviews, as well as methods for securing internal and external validity and the reliability of research results are also addressed. Chapter 3 provides some historical context for the study and shows how the role of national parliaments has evolved during the course of EU integration. It depicts how the Lisbon Treaty has critically altered the conditions for parliamentary involvement in EU affairs. Chapter 4 addresses the context of both national and EU politics in the domains of pension provision and low-skilled labour migration. It provides an overview of the Green Paper on pensions and the Proposal for a directive on seasonal labour migrants, and identifies the challenges that these EU proposals pose to Swedish, Czech and Romanian regulations. Chapters 5, 6 and 7 address the practice of parliamentary scrutiny of EU affairs in Sweden, the Czech Republic and Romania, respectively. These chapters analyse the scrutiny practice of national parliaments pre-Lisbon and assess the scrutiny of the Green Paper on pensions and the Proposal for a directive on seasonal labour migrants in the parliaments of Sweden, Czech Republic and Romania in the aftermath of the Lisbon Treaty. It is shown that in reality parliamentary scrutiny focuses on the division of competences between the EU and national governments, not on the content of EU proposals. The main argument of these chapters is that political parties obtain control over the set-up and implementation of new parliamentary competences at the expense of other parliamentary actors. Chapter 8 
tests the abovementioned expectations about the behaviour of parliamentary actors in the new opportunity structure and attempts to distinguish common trends in the evolution of scrutiny practices in the parliaments of Sweden, the Czech Republic and Romania. The conclusion summarizes the findings of the study and makes a number of suggestions for further research. 


\section{CHAPTER 1: Review of the literature on parliamentary scrutiny of EU affairs}

This chapter highlights a number of debates in the contemporary academic literature on the role of national parliaments in the process of European integration. It shows how research on national parliaments became increasingly empirically driven, with much less focus on formal institutional characteristics and more attention paid to the behaviour and interaction of parliamentary actors in the scrutiny of EU affairs. Several key research areas are identified as well as the change in focus in the recent academic literature from the legislative to the communicative functions of parliaments. The final section of the chapter highlights the shortcomings of contemporary literature on national parliaments in EU integration.

\subsection{Evolution of the academic literature on the role of national parliaments in EU integration}

In the late 1970 s and early 1980 s, the first wave of research on the role of national parliaments in the EU political system was primarily exploratory and descriptive. It was prompted by the introduction of direct elections to the European Parliament in 1979. Research was concerned, for example, with identifying potential scenarios for interparliamentary cooperation, developing hypotheses about the evolution of party links between the national and the European level and describing existing procedures of parliamentary scrutiny (Herman and van Schendelen 1979, Evans 1981, Coombes and Hrbek 1979). The volume by Niblock (1971) is untypical of the 'first generation' of studies as it focuses on the causes of parliaments' limited involvement in EU affairs.

In the 1990s, a more empirically orientated strand of research appeared in a wave of case studies by Rometsch and Wessels (1996), Laursen and Pappas (1995), WeberPanariello (1995) and Smith (1996). Nonetheless, these new contributions were mostly concerned with legal rules rather than with parliamentary practice. They corroborate the 'deparliamentarization' thesis at both the EU and the national levels. The conclusion of a seminal study by Norton (1996) was that national parliaments are fairly weak institutions, which are unable to shape the EU political process according to their own preferences. It is highly symbolic that one of the major contributions to the study of West European parliaments (Döring 1995) does not pay much attention to EU issues.

The third wave of research in early 2000 s continued the 'empirical tradition', but ascribed a more active role to national parliaments in the process of EU integration. The idea that national parliaments had been able to successfully adapt their structures and practice to play a more proactive role in EU policymaking was increasingly accepted. A 
plethora of both single-case and comparative empirical studies emerged: Auel and Benz (2005), Barrett (2008), Zier (2005), Bergman and Damgaard (2000), Holzhacker and Albaek (2007), O'Brennan and Raunio (2007), Raunio and Wiberg (2000), Tans et al (2007), Kiiver (2006a, 2006b), Wessels, Maurer and Mittag (2003) and Maurer and Kietz (2004).

The key point of all these contributions is the idea that European Affairs Committees (EACs) are used to 'domesticate' EU issues and to regain a measure of control over EU integration. As is argued in the volume by Maurer and Wessels (2001, p.19-23), at least some national parliaments can no longer be considered 'losers' in EU integration, as they have become actively involved in EU affairs and attempt to shape both EU policies and their respective executive's positions on EU institutions. Another major finding of the "empirical tradition" is the ever-present discrepancy between strong formal rights and political practice. It has been shown that national parliaments with strong formal scrutiny rights often do not use them in practice, as can be observed in both West European states, for example France and Germany (Sprungk in O'Brennan and Raunio 2007; Grossman and Sauger 2007; Thym in Tans et al. 2007), and East European countries, for example Poland (Lazowski in O'Brennan and Raunio 2007). New insights were also developed into the patterns of executive-legislative relations. In EU affairs, parliaments generally avoid confrontation with national governments, because more flexible tools for influencing their respective position are used. EACs are reluctant to impose rigid mandating instructions - even where this is legally possible - and attempt instead to develop informal consultation regimes with government ministers, which affects the dynamics of executive-legislative relations in EU affairs. As Ladrech (2010, p.90) argues, the attempt to increase parliamentary influence over EU affairs has resulted in a decrease in national parliamentary autonomy.

It also became clear that adaptation by national parliaments to the pressure of EU integration is incremental and path-dependent, driven primarily by domestic political factors and respective national parliamentary traditions (Dimitrakopoulos 2001, p.419420). Case studies of parliamentary scrutiny practices highlight the fact that the creation of European Affairs Committees has not resulted in a high degree of uniformity in national parliaments' influence over EU affairs. Similar institutional design has not been translated into comparable political performance (Raunio 2005, p.320).

Most of the research on national parliaments in the empirical tradition has a distinctly institutionalist outlook. This means that the focus of the research is on committees and other parliamentary structures. It also means that the legislative functions of national parliaments are the key research interest. Recently, the research focus has moved on to the representative and communicative functions of national parliaments, with topics such as media coverage of EU affairs, the role of EU issues in public/plenary debates and constituency service ${ }^{18}$ moving into the limelight. This is an

\footnotetext{
${ }^{18}$ The term constituency service relates to the practice of an MP providing benefits to the electoral district (constituency) that has elected him or her in order to increase the chances of re-election. For a more compre-
} 
important change, as Leston-Bandeira (2012, p.266) argues: "the actual relationship with citizens tends only to be addressed as an indirect outcome of the other core functions of parliament or as a consequence of parliament's relationship with government and/or parties".

\subsection{Key strands of the literature on the role of national parliaments in EU integration}

Contemporary literature on the role of national parliaments can be grouped into several strands according to two criteria: the focus of the research, formal institutional or behavioural; and the level of the analysis, EU-level or national ${ }^{19}$ (see Table 1).

The first large body of literature addresses cross-country variations in parliamentary scrutiny systems and develops typologies of national parliaments. This group of literature has largely focused on the formal characteristics of domestic parliamentary structures. Arguably, the first works on EU integration and national parliaments can be connected to this strand of literature as they initially concentrated on describing scrutiny procedures and formal rights (Kamann 1997). Even the more recent studies on Central and East European parliaments (Szalay 2005) or some comparative studies of the scrutiny systems of 'old' and 'new' member states (Bach 2008) have followed the tradition of concentrating almost exclusively on formal parliamentary competences.

The studies on cross-country variations in parliamentary scrutiny systems can be exemplified by Bergman (1997), Saalfeld (2005) and Raunio (2005b). They suggest a large number of explanatory variables, but the influence of parliament as well as public opinion or party position on EU integration seem the most salient. These findings have been corroborated by Hix and Raunio (2001). The abovementioned variables concentrate on structural factors. Rozenberg (2002) suggests more agency-orientated explanations, such as the role perception of MPs as well as their attitude to democracy. These studies have a major drawback as they deal primarily with the 'old' EU member states. This shortcoming was later rectified by Karlas $(2011,2012)$ and Winzen $(2012,2013)$. They do not find much support for the argument that public or party Euroscepticism explains cross-country differences, stressing that institutional factors such as committee strength, the power of parliament and party system fragmentation should be considered key explanatory variables.

hensive definition of constituency service see, for example, Norris (1996) as well as Dropp and Peskowitz (2012).

19 The second criterion implies that the research concentrates either on the direct involvement of national parliaments in EU-level politics or on the way EU issues are tackled at the domestic level. 
Table 1: Strands of academic literature on the role of national parliaments

\begin{tabular}{|c|c|c|}
\hline & Formal institutional focus & Behavioural focus \\
\hline Domestic level & $\begin{array}{l}\text { Typologies and cross-country } \\
\text { variations } \\
\text { - Typology of parliaments } \\
\text { - Cross-country variation } \\
\text { - Factors of effective parliamentary } \\
\text { scrutiny } 1\end{array}$ & $\begin{array}{l}\text { Practice of parliamentary scrutiny } \\
\text { - Factors of effective parliamentary } \\
\text { scrutiny } 2 \\
\text { - Case studies (single case or cross- } \\
\text { country) } \\
\text { - 'Communicative turn' studies } \\
\text { - Control over CFSP/ESDP } \\
\text { - EU integration and regional } \\
\text { parliaments }\end{array}$ \\
\hline EU level & $\begin{array}{l}\text { Forms of national parliament } \\
\text { involvement in EU-level policymaking: } \\
\text { - Subsidiarity principle / EWS } \\
\text { - Democracy in the EU } \\
\text { - National parliaments and the Open } \\
\text { Method of Coordination }\end{array}$ & $\begin{array}{l}\text { National parliaments' activity at the } \\
\text { EU level: } \\
\text { - Inter-parliamentary cooperation } \\
\text { - Subsidiarity principle / EWS } 2\end{array}$ \\
\hline
\end{tabular}

Several authors also developed a ranking of national parliaments' influence in EU affairs, Maurer and Wessels (2001) providing one of the best examples. Their typology is based on not only dividing scrutiny systems into mandating ${ }^{20}$ and document-based ${ }^{21}$ 'ideal types', 22 but also considering the overall involvement of specific parliaments in both domestic and EU affairs. Another important typology is the work by Wessels and Rozenberg (2013), which is focused on national parliamentary control over the European Council. This work as well as articles by Karlas $(2011,2012)$ and Winzen (2012) constitute one of the few typologies that bring together both 'old' and 'new' member states. This overcomes the key challenge of national parliament typologies - the arbitrariness and subjectivity of assessment (Costa and Rozenberg 2008, pp.258-260). Nonetheless, in the case of Central and Eastern European parliaments, the discrepancy between

\footnotetext{
${ }^{20}$ The logic of the mandating system is to define the scope for government action in the negotiation process. The primary aim is to ensure that a government's course of action in the Council of Ministers has the full backing of a parliamentary majority. The secondary goal is to ensure that the respective government does not deviate from the approved negotiation mandate. The mandate itself can be either legally or politically binding. The key element is that a minister cannot deviate from the position approved by parliament without informing the latter or providing well-defined arguments for doing so.

${ }^{21}$ Document-based scrutiny is focused on screening and examining legislative proposals and other EU documents in order to identify the most salient issues and afterwards consulting the respective minister, although without issuing any explicit voting instructions. A document-based system often includes a 'scrutiny reserve' procedure, which obliges a government to restrain from concluding negotiations in the Council of Ministers until parliament has completed its scrutiny process.

${ }^{22}$ The scrutiny systems of South European member states, the Benelux countries as well as Hungary and Slovakia are hard to classify, and combine features of both mandating and document-based 'ideal types'.
} 
formal rules and practice is yet to be fully taken into account ${ }^{23}$. As Kopecký (2007) argues, the parliaments of Central and Eastern Europe have acquired better institutional capacity, but independent input into the policymaking process has so far been modest. At the same time, almost all existing typologies rank Nordic parliaments as among the most influential in EU affairs, although national differences persist.

Research on the factors determining the efficiency of parliamentary scrutiny has long been driven by theoretical insights from comparative legislative studies. Maurer and Wessels (2001) and later Györi (in O’Brennan and Raunio 2007) developed explanatory schemes that address factors such as: the scope of information, the timing of scrutiny and the impact on government's room for manoeuvre ${ }^{24}$. The first criterion deals with the types of documents a parliament receives, its information channels (through the government or independent of it) and the resources available to carry out scrutiny. As Maurer and Wessels (2001, p.69) claim: "The general orientation of ideas associated with a parliament's control function as well as financial, personal, managerial resources of a parliament may cause the exclusion of various types of EC/EU documents from consecutive phases of scrutiny process". The second criterion, timing, is about the stage in the EU policy process at which parliament gets involved. The earlier a parliament receives information, reacts to it and gets involved in decision-making, the better are its chances of having an impact on policies. The third criterion deals with the procedural mechanisms of parliamentary influence and various types of mandates. Györi builds on the suggestions of Maurer and Wessels, adding several interesting factors, although some of them such as 'Eurocapacity' are hard to operationalize.

The second major strand of the literature on national parliaments and European integration focuses on the practical use of scrutiny procedures. This body of research consists of various studies that attempt to go beyond the formal description of scrutiny procedures, show the functioning of parliaments in practice and test theory-driven assumptions about parliamentary scrutiny.

This strand of literature draws heavily on case studies that address the functioning of national scrutiny systems. In general, case-selection is heavily biased towards Nordic countries (Bergman and Damgaard 2000; Damgaard and Nørgaard 2000; Wiberg 1997; Öberg and Jungar 2009; Damgaard and Jensen 2005) and the 'old' EU member states. Research on parliaments in Central and Eastern Europe and EU integration was for a long time centred on the accession period (Vehar in O'Brennan and Raunio 2007; Kolarksa-Bobinska 2003; Adamcová 2004; Kratz and von Steindorff 2002; Olson and Norton 2007, Ágh 2004, 2006). One of the key findings was that during the accession process, the role of Central and East European parliaments came down primarily to transposing the acquis communautaire into the national legal system. Some researchers

\footnotetext{
${ }^{23}$ For example, the ranking in Winzen (2012) is based on formal rights, which arguably gives the Romanian parliament a score that is not commensurate with its actual input into EU policies.

${ }^{24}$ According to Rozenberg (2002, p.3) these factors were originally proposed by Laprat (1991) and Scoffoni (1992).
} 
(Jungar 2009) argue that Nordic scrutiny systems, especially the Finnish one, were used as a template by the "new member states.

Research dedicated to Central and Eastern European parliaments in the postaccession environment is relatively rare. Existing studies have somewhat disregarded the wider EU context and concentrated instead on the institutionalization of new parliamentary structures, and their role in domestic politics and democratic transition (Olson and Norton 1996; Kopecký 2001; Mansfeldova 2005; Mansfeldova, Olson and Rakušanova 2004; Chiva 2007). Research on the parliaments of the Visegrad group of countries has arguably attracted the most attention, while the Bulgarian, Romanian and Baltic parliaments (Pettai and Madise 2006; Neuvonen 2007) remain relatively underresearched. Nonetheless, all the studies confirm that no uniform pattern of development in Central and Eastern European parliaments can be identified. Moreover, despite initially playing a crucial role in institutionalizing new political systems and consolidating democracy, their political leverage has now diminished (Kropp 2008; Olson and Ilonszki 2011).

The 'second generation' of research on the factors of effective parliamentary scrutiny, for example, studies by Sprungk (2010) and Neuhold and de Ruiter (2010), is also empirically orientated. Sprungk's study of the parliamentary debates on the Water Framework Directive (WFD) concludes that the systematic involvement of sectoral committees and the parliamentary opposition are the key factors in scrutiny effectiveness. Neuhold and de Ruiter test several hypotheses ${ }^{25}$ on the basis of assessing parliamentary debates on the Registration, Evaluation, Authorization and Restriction of chemical substances (REACH) regulation. Despite the fact that the hypotheses were not corroborated, the amount of expertise available to a parliament on the topic addressed in the proposed EU legislation appears to be an important explanatory factor. In fact, access to information can be seen as crucial for parliamentary influence as Maurer (in Barrett 2008, p.55-57) considers parliaments with comprehensive information rights to be the strongest. In the aftermath of the Lisbon Treaty, parliaments can obtain information directly from the EU institutions. The focus on assessing the effectiveness of scrutiny will therefore have to shift from access to information to the ability to process it. This aspect is further developed by de Ruiter (2013), who considers how various information processing costs affect the scrutiny of EU legislation by national parliaments.

Another group of researchers started to explore the connections between the implementation of EU laws and parliamentary involvement. Arguably, this strand of research was triggered by Raunio and Wiberg (2010) as well as Toller (2007), who suggested a number of empirical criteria to measure the level of Europeanization ${ }^{26}$ of na-

\footnotetext{
25 The hypotheses address the relationship between the characteristics of a political system (consensus/majoritarian) and the organization of debates on EU affairs in bicameral parliaments

${ }^{26}$ In Raunio and Wiberg (2010) Europeanization is considered to be the share of a parliament's activities dedicated precisely to EU-related issues
} 
tional parliaments. Further studies (Brouard, Costa, König 2012) looked at how European integration affects the legislative output of national parliaments. The results of their research may help reassess the 'deparliamentarization' thesis, as it was clearly shown that parliaments are largely autonomous from the EU institutions in determining their legislative activity. National differences in parliamentary involvement in EU affairs seem to be explained by the varying patterns of coalition politics. There is further evidence that EU integration has not limited the scope of parliaments' legislative output. On the basis of comparing parliamentary deliberations and the transposition of the Water Framework Directive (WFD in France and Germany, Sprungk (2011) ${ }^{27}$ argues that there is little evidence that effective transposition of a directive is causally related to prior parliamentary involvement. A number of alternative explanations are provided. It seems that there is limited interest on the part of national parliaments in setting up permanent follow-up mechanisms for EU policies. Mastenbroek, Spendzharova and Versluis $\left(2014\right.$, p.765) also concur that "heightened ex-ante scrutiny ${ }^{28}$ does not translate directly into careful ex-post oversight ${ }^{29}$ ", although they stress that the issue of national parliaments' involvement in the transposition of EU legislation merits further investigation.

The literature on the practical implementation of scrutiny rules has also dealt with national parliaments' control over CFSP/ESDP operations (Peters, Wagner and Deitelhoff 2008, 2010; Peters, Wagner and Glahn 2011; Zanon 2010; Bono 2005, Krunke 2007, Böcker 2012, von Ondarza 2012; Raube and Wouters 2012). It is argued that accountability and democratic control over this policy domain are still lacking due to limited parliamentary involvement, although MPs are increasingly aware of these deficiencies. Limited access to foreign policy documents and differences in national scrutiny systems negatively affect the possibility of public debate and information sharing.

A certain amount of attention has been directed to the impact of EU integration on regional parliaments in the work of Raunio and Wright (2006), Kiiver (2006a), Abels (in Abels and Eppler 2011), Vandamme (2012), Högenauer (2014), BoronskaHryniewiecka (2013).

The empirical branch of studies has recently experienced a turn towards studying the communicative functions of national parliaments in EU affairs (Auel and Raunio 2011 , p.9, 47). As a result, the research agenda has shifted to the analysis of parliamentary involvement in EU affairs by addressing topics such as media coverage (de Wilde 2008, 2011a; Wendler 2012), plenary debates (Auel and Raunio 2011) and role theory (Wessels 2005, Auel 2009, Rozenberg 2009). This trend is largely in line with the socalled 'representative turn' in EU studies (Kröger and Friedrich 2013, p.160) in which

\footnotetext{
${ }^{27}$ Contrary to established belief, Sprungk (2013) also argues that parliamentary involvement is not likely to hamper or delay the transposition of EU directives

${ }^{28}$ The authors refer to parliamentary deliberations over a government's negotiation stance in EU affairs

${ }^{29}$ The authors refer to parliamentary scrutiny during transposition of EU legislation.
} 
greater attention is given to relations between representative bodies and their electorates at both the domestic and the EU levels.

Analysis of the linkage between parliaments and their electorates in EU affairs has shown that different scrutiny schemes can be conducive to either content-orientated partisan debates with little public visibility or greater involvement of the public (de Wilde 2011b). On the other hand, in countries with both pro-European and Eurosceptic attitudes, parliaments are reluctant to hold plenary debates on EU affairs, which deprives both the media and citizens of the easiest mechanism for following parliamentary deliberations on EU integration issues.

The third important strand of the literature addresses different forms of parliamentary involvement in EU level policymaking. It focuses on the formal institutional mechanisms of parliamentary activity at the EU level, such as the Early Warning System which controls the compliance of EU legislative proposals with the principle of subsidiarity (Cooper 2006, 2012, 2013a; Bausili 2002; Kiiver 2012; Rothenberger and Vogt 2007; Cartabia, Lupo and Simoncini 2013; EPC, EGMONT and CEPS 2007), as well as conceptual models of national parliaments' involvement in EU affairs. For example, Kiiver (2011) argues that the function of the Early Warning System is comparable to the domestic role of a 'council of state ${ }^{30}$. Various theoretical contributions have primarily stressed the potential limitations of the coordinated subsidiarity checks and the EWS in general, sceptical of their ability to enhance parliamentary input into EU affairs. The extent to which the subsidiarity control mechanism can be used by national parliaments independently of their respective domestic executives is also a matter of debate. According to several authors (Duina and Oliver 2005; Duina and Raunio 2007; Becker 2009; de Ruiter 2010, 2011), the involvement of national parliaments in the Open Method of Coordination (OMC) gives them another instrument for engaging in EU level policymaking. The majority of authors, however, focus on scenario-building, highlighting that both the complexity and the non-binding character of the OMC may preclude effective parliamentary control. Only de Ruiter (2011) assesses the reasons for national parliaments' limited involvement in the $\mathrm{OMC}$, stressing the reluctance of national executives to share OMC data with MPs.

In principle, national parliaments can play an important role in addressing the democratic deficit of the European Union by holding domestic executives and EU institutions to account as well as by providing a platform where policy issues related to the EU can be discussed. Eriksen and Fossum (2000), Katz and Wessels (1999), Harlow (2002) and Rizutto (2003) have considered how national parliaments can contribute to representative and deliberative democracy at the EU level.

The fourth body of literature on national parliaments and EU integration considers how these instruments of participation in the EU-level policy process are used in practice. A good example is research on inter-parliamentary cooperation or relations be-

\footnotetext{
${ }^{30}$ Kiiver refers to the French-style Conseil d'État, which checks the lawfulness of a document but does not deliberate on its content or political desirability.
} 
tween the European Parliament and national parliaments. Most contributions (Neunreither 1994, 2005; Larhant 2005; Costa and Laterk 2001; Bengston, in O'Brennan and Raunio 2007; Crum and Fossum 2009) combine theoretical and empirical insights, but the technical complications of inter-parliamentary cooperation as well as the difficulties of gaining access ${ }^{31}$ and conducting participant observations diminish the number of studies. Regardless of the fact that the transfer of 'best practices' is portrayed as a possible outcome of inter-parliamentary cooperation, relations between the European Parliament and national legislatures are generally described as confrontational, as both strive to define an autonomous niche in the EU multi-level governance system. Nonetheless, the recent volume by Crum and Fossum (2013) shows that inter-parliamentary cooperation already covers a large number of policy sectors. The 'multi-level parliamentary field' (Crum and Fossum 2009) is not a purely theoretical concept but a distinct political phenomenon. The 'multi-level parliamentary field' is also shaped by patterns of cooperation or conflict between the EP and national parliaments (Herranz-Surrallés 2014; Winzen, Roederer-Rynning and Schimmelfennig 2014).

Some studies on subsidiarity and the EWS also fall within this group of literature. For example, Neuhold (2011) and Neuhold and Strelkov (2012) argue that the EWS could trigger more active inter-parliamentary cooperation as networking between the representatives of national parliaments in Brussels might develop from pure information exchange to a conscious attempt to establish common policy positions. The first 'yellow card' against the Monti II legislative proposal has already led to a number of studies (Cooper 2013b, Fabbrini and Granat 2013; Barrett 2012) that trace patterns of interparliamentary cooperation in an attempt to reject the European Commission's policy proposals.

\subsection{The shortcomings of the academic literature on the role of national parliaments and EU integration}

The amount of literature on national parliaments has increased tremendously but, according to Raunio (2009, pp.5-8), there are still several under-researched and overlooked areas. First, a lot of attention is still being paid to formal scrutiny rights rather than political practice, even though it has been demonstrated time and again that national parliaments do not necessarily use the full scope of their powers. In addition, the causes of the discrepancy between formal provisions and actual policymaking have not been sufficiently addressed. There is little information on day-to-day policymaking in European Affairs Committees (Auel 2005, p.309). Arguably, the focus of numerous studies on European Affairs Committees has also biased the research agenda. There is

\footnotetext{
31 There are quite a large number of high-level meetings (COSAC, Inter-parliamentary meetings on CFSP/ESDP, Conference of the Speakers of European Union parliaments etc.) and extensive dialogue between the EU institutions and national parliaments, but it is difficult to assess the kind of policy consequences these contacts have.
} 
no systematic analysis of the practice of involving standing committees in the scrutiny of EU affairs (Kropp, Buche and Buzogány 2011, pp.228-229).

Very limited data exists about the 'micro-level' of parliamentary policymaking in the EU domain, for example, how expertise is acquired or how conflicts between various parliamentary actors are resolved. The majority of existing single or cross-country case studies focus on comparing scrutiny procedures. Few attempt a comparative study of important issues such as the involvement of standing committees or relations with governmental bodies dealing with the coordination of EU affairs.

The extent to which MPs take the rulings of the Court of Justice of the European Union (CJEU) into consideration when conducting the scrutiny of EU affairs or transposing directives also remains largely unknown. Thus far, only one such study exists (Slagter 2009). Research in this field is especially important given the fact that according to the Lisbon Treaty, national parliaments obtain the right to bring the cases on purported violations of the subsidiarity principle before the CJEU.

It is important to stress that research has so far focused on institutional adaptation by national parliaments and their legislative or policymaking functions. Representative and communicative functions of national parliaments in EU affairs have not been addressed to the same extent. For example, the roles of plenary debates, media coverage and constituency service in shaping the outcomes of parliamentary scrutiny remain unclear.

There is also a clear research bias in terms of case selection, as data are predominantly available on Nordic and the West European member states. The parliaments of Central and Eastern Europe remain something of a 'terra incognita' (Holzhacker 2008, p.149).

Despite the fact that parliaments are not unitary actors, few studies differentiate between how various parliamentary actors, such as committee secretariats, parliamentary administrators and MPs, adapt to the pressures of European EU integration. There are also almost no studies that assess how these types of parliamentary actors interact during the scrutiny process. For example, there is almost no research on the role of parliamentary administrators in the scrutiny of EU affairs. The few publications that address the issue date back to early $1980 \mathrm{~s},{ }^{32}$ and these provide only a formal description of British, German and French parliamentary staff rather than an analytical evaluation and they do not take the EU into consideration. Egeberg et al. (2013, p.495) argue that "officials within parliaments seem to have received rather marginal scholarly attention: scholars interested in parliaments traditionally focused on parliamentarians themselves, thus leaving parliament administrations in a 'no-man's land' in the literature",33. Thus far, the only contemporary work dedicated to administrators in national parliaments and

\footnotetext{
${ }^{32}$ See Legislative Studies Quarterly, 6:4.

${ }^{33}$ At the same time there is a large body of literature on staff in the US Congress. See, for example, Hammond (1996).
} 
their role in EU affairs can be attributed to Högenauer and Neuhold (2013) and Christiansen, Högenauer and Neuhold (2014).

The role of political parties has also not been taken into consideration in the assessment of the impact of EU integration on national parliaments (Goetz and MeyerSahling 2008, p.12). Research on national parliaments has made only cursory reference to political parties. For example, König and Mäder (in Brouard, Costa and König 2012) argue that the level of Europeanization of EU legislation depends on the way in which political parties monitor compliance within 'coalition agreements'. Miklin (2011) stresses that inter-parliamentary cooperation primarily affects contacts within party groups and not the pattern of executive-legislative relations. Auel and Ranio (2011, p.15-16) argue that party politics often preclude effective plenary debates on EU affairs because neither a broad consensus on the added value of the EU (Germany), nor the internal division of parties over EU issues (France, the UK) provide sufficient incentives to pay greater attention to EU issues in plenary debates.

This means that the literature on European integration has yet to take full account of the interaction between political parties and parliaments. To provide a better understanding of how these strands of literature are connected, in the section below I examine research on the adaptation of national parties to the process of EU integration. I will present the arguments of proponents and critics of the 'party cartel' thesis, which helps to assess the transformation of party systems at the domestic level.

\subsection{Research on national parties and EU integration}

The literature on national parties and EU integration can be categorized according to the following sub-fields (Mair 2008) ${ }^{34}$ :

1. Emergence of political parties based on a distinct 'European cleavage,35;

2. Impact of EU issues on the patterns of electoral competition and internal party dynamics at the domestic level;

3. Dynamics of pan-European party coalitions and inter-party relations in the European Parliament;

4. Emergence of alternative, non-partisan channels of representation of attitudes to the $\mathrm{EU}^{36}$.

The role of the 'European cleavage' in structuring inter-party electoral competition is a matter of academic debate (Deegan-Krause 2007, Enyedi and Deegan-Krause 2011). For example, according to Mair (2008, p.158), “"despite the increasing volume of work in this area, the European dimension remains too inchoate and incoherent for us to form

\footnotetext{
${ }^{34}$ For a more detailed review of the literature on EU integration and national parties see Ladrech (2009).

${ }^{35}$ Drawing on Knutsen and Scarborough (1995), a cleavage is defined as an expression of social division that serves as a basis for group orientation.

${ }^{36}$ This section briefly addresses the first two sub-fields. The topics of transnational European political party groups and non-partisan representation are beyond the scope of the thesis
} 
a definitive view on its positioning, while its relation to other divides will also invariably vary across national political systems, and in the context of different national complexes of cleavage theory. The idea that attitudes to the European Union constitute an important social cleavage was voiced back in 1990s (for example, Ray 1999). Although authors such as Netjes and Binnema (2007) or van der Eijk and Franklin (2004) argued that the EU dimension plays an increasingly important role in shaping cleavage structure, they also showed that it had had little impact on political processes at the national level. Others, such as de Vries (2007) and de Vries and Tillman (2011), argue that attitudes towards the EU affect voters' choices in national elections, referring to this process as 'EU issue voting'. In other words, they argue that 'European cleavage' does play a role in structuring electoral processes.

The extent to which the rise of Eurosceptic political parties can be considered a sign of an emerging EU cleavage is a matter of contestation. In fact, reference to 'Europe' as a central element of party identification may not be a matter of ideology or cleavage structure, but a way for marginal parties to enter the political debate. Key studies on Euroscepticism, such as the numerous contributions by Szczerbiak and Taggart $\left(2000,2002\right.$, and 2008), support this idea ${ }^{37}$. They consider Euroscepticism to be either a symptom of an anti-establishment social movement or a sign of factional conflicts within mainstream political parties - not a reflection of an emerging 'European cleavage'.

When it comes to the impact of EU issues on internal party dynamics and patterns of electoral competition, most studies acknowledge that the EU has triggered 'programmatic change' but not 'organizational change' (Raunio 2002; Poguntke 2007; Ladrech 2010, pp.134-137) ${ }^{38}$. This implies that although political parties make reference to EU issues in their programmes and manifestos, they have not changed their internal structures in order to reflect the allegedly growing salience of EU issues.

At the same time a number of authors (for example, Nanou and Dorussen 2013) stress that EU integration has diminished the 'room for manoeuvre' for political parties due to the harmonization of policies and hence limited the opportunities for contestation. As a result this reduced the capacities of political parties which form the government. This leads to a de-politicization of inter-party competition as elections become less attractive, given that voters have fewer alternatives to choose from.

It is arguable that the de-politicization of inter-party competition might not only be the result of EU integration. It could also reflect the process of cartelization of national

\footnotetext{
${ }^{37}$ On the issue of party-based Euroscepticism see Szczerbiak and Taggart $(2008,2013)$, Kopecký and Mudde (2002), Conti and Memoli (2012), Vasilopoulou (2013).

${ }^{38}$ Külahci $(2012$, p.3) argues that the literature on national parties and EU integration is centred on the MairLadrech debate, the former claiming a 'non-Europeanization of party systems', while the latter stipulates that Europeanization does have an impact on national party systems. In the opinion of the author of this dissertation such a distinction is overstressed, as both Ladrech and Mair do not simply profess the EU's influence or non-influence on national parties, but assess which elements of party structure and party activity are susceptible to such influences.
} 
party systems (Katz and Mair 1995, 2009). Cartelization means that incumbent parliamentary parties limit the capacities of new parties to enter elections, become increasingly autonomous from voters and unwilling to engage in mobilizing on new electoral issues. Political parties become insulated from voter preferences as close cooperation between majority and opposition ensures that neither is forced to leave parliament as a result of electoral defeat.

Despite its heuristic value, the cartel party approach has been criticized for a number of shortcomings. The first is the overarching generalization and disregard for the 'micro-foundations' of party politics. Authors such as Kitschelt (2000), Loxbo (2013) and Birnir (2010) have questioned the idea of the increasing autonomy of party leaders from voters and their preferences. Second, it is difficult to find evidence to support the existence of a party cartel or to operationalize the concept. For example, Detterbeck (2005) and Pelizzo (2008) claim that the alleged new organizational forms of a cartel party - the marginal role of party activists, the crucial role of public office-holders in structuring the intra-party debate, and so on are not present in all party systems that exhibit cartel characteristics. Moreover, high levels of public funding available to parties cannot necessarily be considered a sign of cartelization (Sandri and Pauwels 2010; Haregel 2008; van Biezen and Rashkova 2011; Scarrow 2006). Third, the evolution towards a cartel party is often presented as a linear and irreversible process, while in fact parties can shift between different modes of organization depending on whether they are in opposition or government (Koole 1996, Bolleyer 2009). Several authors (for example, Sandri and Pauwels 2010, p.1258) argue that the "cartel party model is more a set of hypotheses and suggestions on party change processes rather than a cohesive and structured model of party development".

Ultimately, there has been no overarching assessment of how the EU is responsible for party system change (Ladrech 2012, p.574). At the same time, most evidence on how European integration affects national party systems comes from Western Europe. Further work must be done to integrate party evolution into a single theoretical framework for both old and new EU member states (von dem Berge and Poguntke 2013, pp.313-315). Having discussed the literature on the impact of EU integration on national party systems and national parliaments, section 1.5 outlines the place of this thesis within the wider field of EU studies.

\subsection{Contribution of the dissertation to the field of EU studies}

The key contribution of this study is the analysis of national parliaments' activities in the post-Lisbon political environment. In this context the thesis addresses the lack of information on the practical implementation of formal scrutiny provisions in the aftermath of the Lisbon Treaty. It concentrates on the 'micro-level' of parliamentary policymaking and provides insights into the actual practices of various parliamentary actors. 
The thesis overcomes the traditional bias of studies on national parliaments and European integration by including parliaments from Central and Eastern Europe, which increases the external validity of the research results and allows for a more comprehensive understanding of the adaptation of national parliaments to EU integration.

The dissertation elucidates the relations and influence of the various parliamentary actors involved in the scrutiny process - political parties, parliamentary administrators and committees. Crucially, the behaviour of political parties is taken into account while considering the adaptation of national parliaments to the pressures of EU integration ${ }^{39}$. In contrast to Holzhacker $(2002,2005)$, the dissertation offers a more critical assessment of the role of the opposition in the parliamentary scrutiny of EU affairs. The involvement of the opposition is important, although it cannot singlehandedly guarantee the effectiveness of scrutiny. What matters is the level of conflict between the parliamentary majority and the opposition, as a high level of discord precludes effective debate and increases the chances of important technical elements of EU proposals being disregarded. Despite the fact that the role of parliamentary administrators has increased, their ability to shape the outcome of the scrutiny process often remains at the discretion of MPs. Political parties also appear to influence the way parliamentary committees address EU issues.

The impact of attitudes to the European Union on parliamentary scrutiny of EU affairs is also explored. Following the suggestion of Mair (2008, p.162), the study goes beyond purely EU-related explanations and adopts insights from comparative politics (party cartel and cleavage theory) in order to explain the impact of attitudes to the EU on parliamentary scrutiny and the types of reaction by parliamentary actors to the new postLisbon environment.

${ }^{39}$ Green-Pedersen (2010, p.361) argues: "Although everyone would probably agree that parties are crucial actors in West European parliaments, these two bodies of literature have rarely engaged with one another, and there is a clear need to 'bring parties in' with regard to understanding the developments in Western European parliaments". 


\section{CHAPTER 2: Concepts, theories and methods}

Authors stress that the scrutiny process is affected not only by the intentions of political actors but also by structural conditions such as the level of Euroscepticism (Raunio 2005b) and established parliamentary traditions (Neuhold and de Ruiter 2010). The concept of "opportunity structure" covers these factors. Nentwich (1996) has used the concept of 'opportunity structure' to address policy-making at the EU level. Within the framework of this thesis I adapt the concept of "opportunity structure" in order to be able to analyse the behaviour of national parliaments in the aftermath of the Lisbon Treaty. In this thesis I refer to 'opportunity structure' as national parliaments' room for manoeuvre in the post-Lisbon political environment. Drawing on Hirschman (1997) and Dowding et al. (2000), the concepts of 'threat of issue exit', 'voice' and 'neglect' are used to develop a typology of reactions by parliamentary actors to the new political environment. In order to explain why parliamentary actors choose to adopt a particular type of behaviour, the thesis draws on two concepts adopted from comparative politics literature - 'party cartel' (Katz and Mair 1995) and 'political cleavage' (Knutsen and Scarborough 1995; Mair 2007, Kriesi 2008). Based on these insights it is possible to predict several strategies of parliamentary actors (parliamentary administrators, political parties, parliamentary committees) within the new opportunity structure.

Moreover, the chapter addresses the inductive qualitative research design of this thesis. In addition, the logic of case selection is explained as well as the methods for obtaining empirical evidence (interviews) and analysing it (process-tracing). Special attention is paid to the instruments for guaranteeing the validity and reliability of claims made about the behaviour of parliamentary actors in the new opportunity structure.

\subsection{Opportunity structure}

The concept of 'opportunity structure' was introduced in social movement theory (Eisinger 1973; McAdam 1982; Tarrow 1989; Kriesi et al., 1992; Kitschelt 1986, etc.). It was first used to analyse protest movements, but later applied to the study of political participation in general. The ultimate goal in applying this concept is to define the conditions under which people engage in collective action, for example available resources, institutional arrangements and organizational forms as well as past experience with political mobilization. Current research engages with what Sartori called 'conceptual travelling', applying the notion of 'opportunity structure' in a different domain. According to Nentwich (1996, p.2), opportunity structure can be defined as "various types of channels of access to the public sphere and to the policy-making and implementation 
processes" ${ }^{\prime 4}$. It should also be stressed that 'opportunity structure' is primarily a heuristic device. The concept does not provide explanatory power in itself but helps to identify patterns within the empirical evidence. 'Opportunity structure' provides a template against which the formal setting (structure) and the actions of various agents (agency) can be analysed (see Figure 1). It is not just a mere descriptive device of contemporary scrutiny arrangements. While the 'opportunity structure' reflects the setting in which national parliaments can be involved in EU affairs, the concepts of 'voice', 'threat of issue exit' and 'neglect' (see section 2.2) describe the different strategies parliamentary actors can choose to resort to, in the process of adapting domestic scrutiny rules and practices in the post-Lisbon environment. 'Party cartel' and 'political cleavage' are the concepts that help understand why parliamentary actors choose a particular behavioural strategy.

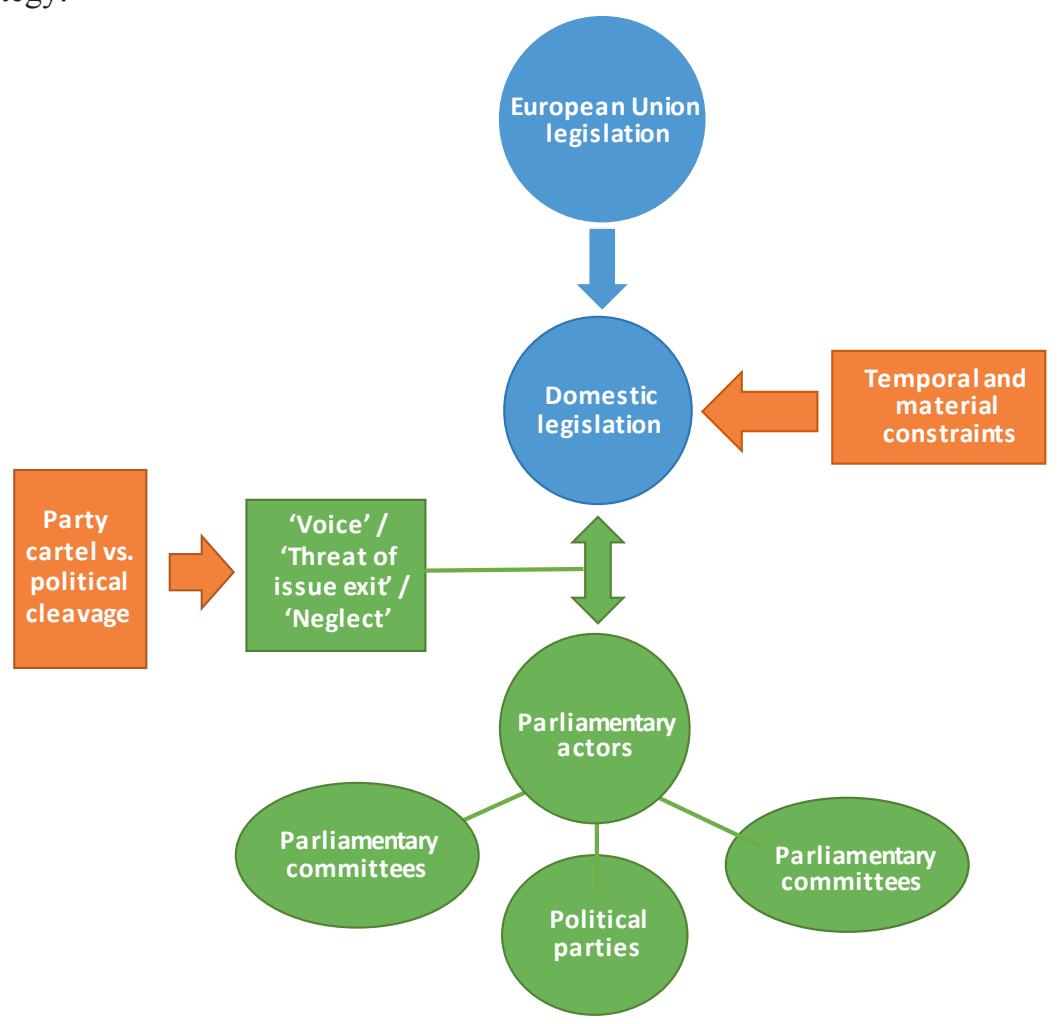

Figure 1: Opportunity structure for national parliaments in the aftermath of the Lisbon Treaty

\footnotetext{
${ }^{40}$ To a large extent the concept of 'opportunity structure', which underlines the ability of political actors to choose the various arenas to best pursue their interests, is similar to 'venue shopping'. For example, see Guiraudon (2000). Within the framework of this study, it is considered that 'venue-shopping' addresses actor behaviour within a specific policy domain or decision-making process, while 'opportunity structure' deals with the political system at large the choices which are available to an actor irrespective of the differences between various policy fields.
} 
When applied to the role of national parliaments in the EU political system, opportunity structure is comprised of several elements. The first element consists of the provisions of the Lisbon Treaty which created a new environment for the involvement of national parliaments' in the EU policymaking process. Second, there is 'domestic legislation' which transposes the new legal provisions of the Lisbon Treaty by means of constitutional changes, the adoption of new parliamentary rules of procedure, changed scrutiny rules, establishing new parliamentary bodies, and so on. It should be noted that implementation of the new rules is dependent on 'temporal and material constraints', such as the availability of resources and additional staff, timely submission of documents, access to information databases and the ability to call on external experts. As a result of ratifying the Lisbon Treaty, domestic legislatures can also interact with EU-level policy actors, for example, the European Commission and the European Parliament.

The implementation of new formal rules by national parliaments depends on the behaviour of 'parliamentary actors', which shape a parliament's response to the new post-Lisbon political environment. National legislatures are not unitary institutions. Hence, various parliamentary actors, for example, political parties, parliamentary committees and administrators, may have different preferences for how the new formal rights can be used. It should be noted that even if parliamentary actors make limited or no use of the new opportunity structure, the political options offered by it remain in place and can be utilized at a later stage. It can be assumed that as long as the new competences granted by the Lisbon Treaty are not formally revoked, they continue to remain at the disposal of the national parliaments and can be activated at a later stage.

\subsection{Types of actor reactions to the new opportunity structure}

Ultimately, parliamentary actors can interpret the new Lisbon Treaty provisions and react to the new opportunity structure in a variety of ways. It should be recalled, however, that the way parliamentary actors behave in the new political environment might be path-dependent or, in other words, largely determined by existing parliamentary traditions and established routines ${ }^{41}$. This could mean that patterns of parliamentary actors' behaviour remain 'locked-in' in the aftermath of the Lisbon Treaty - they could be very difficult to change and remain 'inflexible'.

Research by Hirschman (1970) on organizations' responses to crises provides a number of clues about developing a typology of parliamentary actors' responses to the new opportunity structure. The term 'crisis' should not be taken literally, but is used instead to denote any major change in the political environment that is substantially different from previous practice. Taking the example of consumers' reactions to a decline in the quality of a product, Hirschman argues that three types of action are possible, 'exit', 'voice' and 'loyalty', all of which constitute 'ideal types'. The initial mean-

\footnotetext{
${ }^{41}$ For discussion on the concepts of 'path dependence' and 'lock-in' see Pierson (2000), Mahoney (2000), Schmidt (2009)
} 
ings that Hirschman attached to 'exit', 'voice' and 'loyalty' have been slightly modified within the framework of this research" ${ }^{42}$.

In Hirschman's research 'voice' implied complaining about a product in order to increase its quality. In the context of this study, 'voice' means an attempt by parliamentary actors to promote their views and shape the outcome of the scrutiny process through negotiation. This could be done through the new parliamentary competences enshrined in the Lisbon Treaty. Accounts of debates over the reform of scrutiny rules, assessment of EU proposals within the context of the Lisbon Treaty provisions on national parliaments can be considered as 'voice'. Hirschman defined 'exit' as stopping consumption of a product of an undesirable quality and choosing another commodity instead. Within the context of this thesis it is more accurate, however, to conceptualise this as 'threat of issue exit'. This implies that parliamentary actors that find it difficult to achieve their goals in the domestic arena can relegate the debate on certain policy issues to the EU level in order to obtain the necessary support and exert pressure on the domestic political arena. 'Threat of issue exit' does not mean leaving the domestic political arena completely, but implies instead the ability of parliamentary actors to pursue their interests at both the national and the EU levels, depending on which is more beneficial to them. Inter-parliamentary cooperation, contacts between MPs and Members of the European Parliament (MEPs) or dialogue with EU level institutions and stakeholders can serve as channels for the 'threat of issue exit'. Moreover, 'threat of issue exit' implies not just any kind of contact between a national parliamentary actor and an EUlevel organization, but a conscious attempt to influence policymaking by gathering information or developing political alliances which can be detected through interview data. The entry into force of the Lisbon Treaty means that national parliaments can better engage in building channels for using the 'threat of issue exit', for example to establish formal contacts with EU institutions or other national chambers. Crum and Miklin (2011, p.3) argue that "coordination and cooperation between parliaments may strengthen parliamentary powers overall and, hence, increase the powers of democratic representation within the complex, multi-level polity of the EU'. Nonetheless, it should be recalled that, as Bartolini (2005, p.6-7) argues, the difference between 'voice' and 'threat of issue exit' is often not clear-cut. It should also be stressed that the use of either of these strategies is contingent on the policy issues at stake, the availability of resources or the potential sanctions that can be incurred. 'Voice' was already available to parliamentary actors, but the Lisbon Treaty has changed the context in which it can be exercised and provides new mechanisms for expressing it. Moreover, because the Lisbon Treaty provides national parliaments with more competences to conduct interparliamentary cooperation, parliamentary actors can start using 'threat of issue exit' more often.

\footnotetext{
${ }^{42}$ For another interesting interpretation of Hirschman's legacy see Wilsford (1974), who merges Hirschman's concepts with the notion of open and closed policy arenas. Also see further self-reflection by Hirschman (1980) on the relationship between 'voice' and 'exit'.
} 
Hirschman also introduced the category of 'loyalty', but it is not included in this thesis. For Hirschman, 'loyalty' implies a situation in which a customer consistently opts for a commodity or service even if its quality has drastically declined. It is unclear what 'loyalty' would mean in the context of the current research - perhaps preference for the status quo or adherence to a party position. Different parliamentary actors (administrators, party advisers, MPs) would have varying 'reference points' for loyalty. Operationalising 'loyalty' within the context of this research remains difficult. However, an important aspect has to be addressed. Political actors are not always interested in creating effective institutions which could maximize their benefits and lead to a 'positive sum game' (Krogh 2011; Moe 2005, 1990). Occasionally, institutions are deliberately created ineffective or the status quo is preferred to reform. In order to describe this situation the concept of 'neglect' (Dowding et al. 2000) seems more appropriate than the concept of 'loyalty'. 'Neglect' represents a situation in which various parliamentary actors are unable or unwilling to use the opportunities provided by the Lisbon Treaty. While 'threat of issue exit' or 'voice' provide parliamentary actors with opportunities to pursue their goals, 'neglect' actually limits their options.

It can be argued that the choice of a specific reaction, be it 'voice', 'neglect' or 'threat of issue exit', by a political actor within the new opportunity structure is not random but can be explained by a number of factors. The two theoretical approaches of 'party cartel thesis (Katz and Mair 1995, 2009) and 'EU political cleavage' (for example, Kriesi 2007, 2008) offer alternative explanations for why parliamentary actors chose 'voice', 'threat of issue exit' or 'neglect', depending on the role of EU issues in structuring political competition.

\subsection{The concepts of 'party cartel' and 'EU political cleavage'}

The party cartel thesis implies that national party systems evolve towards high dependency on state financing ${ }^{43}$, a de-politicization of the electoral agenda, collusion ${ }^{44}$ between majority and opposition parties and an unwillingness to mobilize around new topics, such as EU affairs, in inter-party competition. De-politicization of inter-party competition acts as a 'safety net' that protects parties from electoral volatility, guaranteeing all parties a share of electoral gains and ensuring that there are no outright 'losers' in the electoral process.

\footnotetext{
${ }^{43}$ It should be noted that dependency on public finances cannot be considered the sole explanation for party system change. See Pierre, Svåsand and Widfeldt (2000).

${ }^{44}$ The term 'collusion' implies that both ruling and opposition parties prefer not to engage in competition but cooperate instead and coordinate their activities in order to secure electoral gains for all political parties. Ultimately, 'collusion' refers to the hollowing out of national party competition: differences between government and opposition become blurred and inter-party competition becomes contained and managed (Mair 2008, Katz and Mair 2009). Development of a cartel party depends on "collusion and cooperation between ostensible competitors, and on agreements which, of necessity, require the consent and cooperation of all, or almost all, relevant participants" (Katz and Mair 1995, p.17).
} 
Proponents of the 'party cartel' thesis argue that EU integration has contributed to the depoliticization of EU affairs in inter-party competition. The transfer of competences to the technocratic and non-partisan EU system and the growing conviction that the traditional concerns of domestic executives (unemployment, taxes, inflation, etc.) are beyond the scope of their immediate control reduce the stakes of inter-party competition for government office, making collusion and cooperation between political parties much easier to achieve. According to Mair (2006), this leads to a 'hollowing out' of democratic processes across Europe as political parties lose representative and acquire primarily governing functions, disengaging from their supporters and the electorate. Referring to a metaphor of Van Eijk and Franklin (2004), Mair (2007, p.13) claims that the "giant" is deliberately sedated".

Ultimately, the 'party cartel' thesis implies that regardless of the new competences that either national or EU-level institutions of representative democracy acquire in the aftermath of the Lisbon Treaty, the structure of national party systems prohibits a greater focus in parliamentary debates on EU affairs. In cases where the 'party cartel' thesis proves correct, parliamentary actors are largely expected to 'neglect' the opportunities provided by the Lisbon Treaty. 'Threat of issue exit' will be used predominantly by political actors not included in the cartel, for example marginal Eurosceptic or antiestablishment parties which will use EU issues to defeat mainstream political actors in electoral competition. 'Voice' is unlikely to be used much as few actors have an incentive to raise EU issues in profound political debates. Those EU member states in which party systems exhibit strong cartelization characteristics are likely to have less interest in developing strong parliamentary scrutiny of EU affairs.

The approach that sees the existence of an EU-related political cleavage suggests a different type of actor behaviour in the new political environment. Drawing on Knutsen and Scarborough (1995), a cleavage is an organized expression of social or political division that serves as a basis for group orientation ${ }^{46}$. The 'EU political cleavage' refers to a situation where attitudes towards the European Union become a crucial element of inter-party competition (van der Eijk and Franklin 2004, Mair 2008). According to Franklin (2010) and Green-Pedersen (2012), new contentious social issues become politically salient only if they can be related to the existing cleavage structure, such as the left-right divide ${ }^{47}$, bring electoral benefits and be perceived by political actors as an effective instrument of self-identification. Drawing on Dinan (2012, p.97-98) it could be argued that the Lisbon Treaty intensifies EU integration, "making EU's impact on policies and politics far more conspicuous in everyday life". Hence, political actors and voters can perceive EU issues and the 'traditional' domestic left-right cleavage as increasingly interrelated. The Lisbon Treaty might increase the instances of so-called 'EU

\footnotetext{
${ }^{45}$ Mair uses this term to refer to the public debate on EU issues.

${ }^{46}$ For the debate on the definitions of a cleavage see West European Politics, 33:3

${ }^{47}$ In fact, an influential school of thought (Hix 2004, Hooghe et al. 2002, 2004; Marks and Steenbergen 2002, 2004, Marks and Wilson 2001 etc.) argues that the EU issue has been subsumed into the traditional left-right divide
} 
issue voting' (de Vries 2007, 2011), where attitudes to the EU influence voters' preferences in domestic electoral politics. This could create greater demand for parliamentary scrutiny of EU affairs and intensified parliamentary debates on EU topics. In these circumstances, parliamentary actors will increasingly use 'voice' and/or 'threat of issue exit' to address EU issues as this provides a clear political benefit for parliamentary actors. It should be noted, however, that if the 'EU political cleavage' is not present in political contestation, then parliamentary scrutiny of EU affairs will not be accorded much importance by parliamentary actors.

Hence, while according to the 'party cartel' thesis the scrutiny of EU affairs will remain a marginal parliamentary activity, the cleavage theory suggests exactly the opposite - a growing importance of parliamentary scrutiny of EU affairs as the Lisbon Treaty makes political actors increasingly aware of the connections between EU-level and domestic politics ${ }^{48}$.

\subsection{Parliamentary scrutiny, political influence and parliamentary strength}

According to Holzhacker (2008, p.143), parliamentary scrutiny can be defined as the "exercise of power by the legislative branch to control, influence or monitor government decision-making". Drawing on Auel and Benz (2005, p.387-389), it is possible to argue that focusing only on attempts by national parliaments to control and monitor their respective executives does not depict the full spectrum of parliamentary involvement in EU affairs. Influence is a broader concept that captures not only ex-post functions, such as monitoring whether the government has followed negotiation instructions at the EU level, but also ex-ante functions, such as shaping the government's negotiation agenda by selecting documents for scrutiny or providing a mandate. In other words, the concept of influence captures a wider spectrum of parliamentary activities, and is not limited to the confrontational pattern of executive-legislative relations which the concepts of monitoring and control imply. The functions of a parliament are not limited to influencing or controlling the executive. The representational and system maintenance activities of a legislature (Mezzey 1979), that is, the aggregation of interests and socialization of members of the elite, are also important. It is assumed, however, that these functions go beyond the issue of parliamentary scrutiny, which is the focus of this research.

Despite the fact that agenda-setting can be considered an important mechanism of parliamentary influence (Döring 1995), this may not be applicable to the scrutiny of EU affairs. First, agenda-setting cannot be taken as the sole yardstick for evaluating parliamentary influence, as governments are often the most important players in legislative agenda-setting (Rasch and Tsebelis 2010). Second, in the case of EU affairs, the agenda is already 'imposed' by the legislative and non-legislative activities of the European Union. Hence, parliaments play a more reactive role, attempting to shape EU proposals

${ }^{48}$ The explanatory power of these two approaches is analysed in Chapter 8 
or to prevent their further discussion through the Early Warning System (EWS). Although national parliaments can under certain conditions affect the EU agenda through subsidiarity control, they still have no right of legislative initiative in the EU political system, which limits their agenda-setting powers. At best, they have only indirect means - through their respective national governments - to propose EU-level legislation. On the other hand, it might be more proper to talk about the agenda-setting power of various parliamentary actors during the scrutiny process of EU affairs, rather than about the agenda-setting power of a parliament as a whole. Different groups of parliamentary actors can determine which subjects are selected for scrutiny out of a multitude of EU proposals and which are ignored or just taken into consideration, thereby influencing and shaping the response of a parliament to specific EU initiatives.

Building on Dahl and Stinebrickner (2003, p.17), it can be argued that influence takes place when political actor ' $A$ ', intentionally or not, affects and changes the actions or preferences of political actor ' $\mathrm{B}$ ' so that the transformation in the behaviour and actions of ' $\mathrm{B}$ ' would not have come about without the involvement of ' $\mathrm{A}$ '. Parliamentary influence should not be considered to fall exclusively within the framework of executive-legislative relations. In parliamentary democracies, the strong connections between the parliamentary majority and the government do not allow talk of 'pure' executive-legislative relations.

Within the framework of the current study, a parliament is considered to be influential when:

a. The government changes its own logic of argument over a scrutinized document after negotiations with parliamentary actors;

b. Amendments to a certain document are supported by both the parliamentary majority and the opposition even though it goes against the interests of the government.

This definition is meant to reflect the idea that parliaments do not necessarily need to exert influence over governments through threats of formal sanctions such as votes of confidence, mandating or motions. There are more subtle instruments that allow parliaments to structure the policy process according to their own preferences. This dual definition of influence corresponds to what Tsakatika (2007, p.554-555) defines as the parliamentary functions of 'democratic check' and 'forum'. Democratic check refers to a parliament's ability to uphold the constitutional division of powers. The 'forum' function symbolizes a parliament's capacity to act as a platform for reaching consensus. Despite the fact that McGann (2006) emphasizes the deliberative functions of a parliament as its key mechanism for exerting influence, only a balanced execution of both 'forum' and 'democratic check' can guarantee substantial parliamentary input into decision-making.

It should be acknowledged that the abovementioned definition of parliamentary influence is rather general and addresses parliamentary behaviour predominantly in the context of national politics. It is necessary to understand the extent to which this defini- 
tion is applicable to the domain of EU affairs, as so far it remains unclear whether a parliament with strong influence in domestic politics will always have a similarly strong impact in the field of EU affairs. This issue is considered when analysing the process of scrutinizing EU proposals in the parliaments of Sweden, the Czech Republic and Romania. Arguably, the concept of 'parliamentary influence' aims to describe a parliament's role in a specific procedure or policy process. In order to take stock of a parliament's role within the political system at large, the concept of 'parliamentary strength' can be used ${ }^{49}$.

A large number of definitions of 'parliamentary strength' have been developed. Most of them build on the debate between Mezey and Norton (Arter 2006a, p.247), which addresses the possibility of considering a parliament's ability to veto a government's decisions as a measure of its strength. Another important approach stresses the distinction between 'working parliaments', represented by the Nordic countries, and 'talking parliaments', the best example of which is the UK. On the other hand, as Auel and Raunio (2011, p.70) argue, this distinction has little explanatory power for assessing a parliament's involvement in EU affairs. Other definitions of 'parliamentary strength' deal with the concept of 'viscosity' developed by Blondel (1970), that is the degree of subordination of a parliament to a domestic executive, or address the distinction between 'transformative' and 'arena' legislatures suggested by Polsby (1975).

Regardless of the concerns which are often voiced about the explanatory power of the different definitions of 'parliamentary strength', providing such a definition in this thesis is crucial as it serves as a basis for case selection, reflecting the differences in various national parliamentary traditions. All the definitions of 'parliamentary strength' address the two criteria of legislative efficiency, the ability to make informed policy decisions; and legislative autonomy, the extent to which it can act as a check on and balance to the executive.

These criteria serve as a basis for the definition of 'parliamentary strength' used within the framework of this dissertation. A national parliament is considered strong if:

a. It has the capacity to gather and analyse information independently of the government;

b. It can force the government to accept its point of view.

\subsection{Expectations about behaviour of parliamentary actors in the new opportunity structure}

The status of "weak" or "strong" parliament does not by itself predict the behaviour of different types of parliamentary actors within the new opportunity structure. On the

\footnotetext{
${ }^{49}$ The concept is ultimately linked to such crucial political science terms as power and influence. The author is aware of the potential differences between these two terms although for this specific research they are considered negligible. For an overview of the debate on defining political power and political influence see Zimmerling (2005).
} 
basis of existing academic research, a number of expectations can be derived about the behaviour of parliamentary actors, such as parliamentary administrators, parliamentary committees and political parties, in the post-Lisbon political environment.

Parliamentary administrators play a crucial role in the functioning of legislative chambers by managing document flow and providing analysis. However, their impact and role in shaping the outcomes of the scrutiny of EU affairs has been overlooked until recently. A number of recent studies (Neunreither 2006; Dobbels and Neuhold 2013; Neuhold and Dobbels 2014; Egeberg et al. 2013) have stressed the importance of parliamentary staff in EU affairs in the European Parliament ${ }^{50}$.

The Lisbon Treaty provides national parliaments with direct access to a large amount of EU documentation, which is likely to increase the role of parliamentary administrators in organizing the flow of documents, selecting policy proposals for scrutiny and providing MPs with the necessary analysis. This could increase the political influence of parliamentary staff as MPs become dependent on their skills in providing information and expertise, especially, according to DeGregorio (1994), on complex and technical issues. Moe (2005) argues that although bureaucrats are considered 'neutral', they inevitably develop a set of political preferences and do not limit themselves to exercising purely technical tasks. The crucial role of parliamentary civil servants in document selection, preparing the agenda and conducting an assessment of EU proposals allows them to shape the outcomes of the scrutiny process. Högenauer and Neuhold (2013, p.12-15) have shown that in the aftermath of the Lisbon Treaty, parliamentary staff members play an important role in the conduct of EU affairs scrutiny. Moreover, parliamentary administrators can influence the set-up of scrutiny rules. The Lisbon Treaty provisions have to be transposed into domestic parliamentary rules and procedures, while the 'institutional memory' (Winzen 2011) (1) $^{51}$ and special knowledge of parliamentary staff are necessary prerequisites for managing the process, allowing them to shape scrutiny rules according to their own preferences.

Despite the fact that parliamentary civil servants are likely to have a greater impact on the scrutiny process in the post-Lisbon political environment, their freedom of action, as Högenauer and Neuhold (2013, p.20) note, can be constrained by MPs and political parties. Political parties remain an indispensable element of a parliament's organization. Previous academic research has shown that political parties' involvement and interest in EU affairs vary according to their opposition or government status, as well as their place in the national political spectrum (mainstream centre-right and centre-left or extremist or marginal parties). Most researchers, for example Auel and Raunio (2011),

\footnotetext{
${ }^{50}$ Winzen (2011) has also addressed the issue of parliamentary staff in the EP. However, in contrast to Neunreither (2006), Dobbels and Neuhold (2013), Neuhold and Dobbels (2014) as well as Egeberg et al. (2013), he is more skeptical about the ability of parliamentary staff to shape the policy-making process in the European Parliament.

${ }^{51}$ Winzen (2011) refers to the role of committee secretariats in the European Parliament in providing 'institutional memory'. Committee secretariats and parliamentary staff in national parliaments exercise a similar function
} 
Ladrech (2002) and Raunio (2009), stipulate that currently it is primarily the marginal Eurosceptic parties that address EU issues in electoral competition. Centre-right and centre-left parties, whether they are pro-European or "mildly" Eurosceptic, are seen to keep a low profile on EU issues in their relations with voters. Euroscepticism is considered one of the key factors in explaining parliamentary activity on EU affairs (Bergman 1997, Saalfeld 2005, Raunio 2005b, Hix and Raunio 2001), but this approach has been questioned by Winzen (2013), and other studies show that centrist parties avoid politicizing EU topics even in highly salient cases (for example, Riekmann and Wydra 2013). Thus in the light of the abovementioned recent studies the thesis will not consider Euroscepticism as the crucial factor explaining the outcomes of parliamentary scrutiny.

As according to Dinan (2012, p.97-98) the Lisbon Treaty and the intensification of European integration makes the EU's impact on national policies "far more conspicuous in everyday life", this could create the conditions under which not only marginal Eurosceptic but also centrist pro-European political parties become interested in EU issues. The increased interaction between the EU and the national policy levels could make all types of political parties aware of the benefits of addressing EU issues for advancing their policy preferences and achieving electoral goals. This means that political parties will also address the content of EU policy proposals in greater depth, exploring potential synergies with their policy preferences.

Government and opposition parties also have different incentives in EU affairs scrutiny. Holzhacker $(2002,2005)$ as well as Auel and Benz (2005) argue that in principle, the opposition is more active in the scrutiny process as it tries to compensate for the power asymmetry, while the parliamentary majority has few incentives to question its own ministers unless there is a strong internal party conflict. Moreover, the ability of the opposition to shape the scrutiny process is greater in minority than in majority governments (Bergman 2000, Raunio 2005) as in the former case the government is forced to seek support from the opposition in order to secure a stable decision-making process. Greater involvement by the opposition in the scrutiny process is likely to help develop a stronger parliament as Zubek (2011, p.174) argues that "the more powers the opposition party has to ensure that their bills provide the basis for parliamentary debates, the greater the autonomy of parliament from government". At the same time, the parliamentary arena can be used to control compliance by government supporting parties to a coalition agreement, a pattern that can be observed in both domestic politics (Martin and Vanberg 2011) and EU affairs (Holzhacker 2002). The Lisbon Treaty provides new formal mechanisms for both opposition and governing parties to pursue their interest in EU affairs.

Despite the importance of inter-party relations, the functioning of parliamentary chambers also depends on the existence of committees (Shaw 1998), which can serve a number of alternative purposes. The work of parliamentary committees can be focused on providing information and expertise to the whole chamber (Krehbiel 1991), assisting with the career advancement of MPs through specialization in distinct policy sectors and 
constituency service (Shepsle and Weingast 1981), or establishing the compliance of parliamentary activity with the position of the majority (Cox and McCubbins 1993) ${ }^{52}$. Given that all national parliaments of the EU member states have established a committee to deal with EU Affairs, it is important to consider which of these aspects is most relevant for explaining committee behaviour in the domain of EU affairs. As mentioned above, the Lisbon Treaty increases national parliaments' access to EU information and gives a boost to inter-parliamentary cooperation and the development of relations with various EU institutions. This is a challenge for every parliament's internal bureaucracy as information has to be secured and analysed, and various tasks related to EU topics at both the domestic and the supranational levels have to be coordinated and divided among MPs. Hence, it is likely that parliamentary committees, which form the backbone of each national legislature (Strøm 1998), and especially the EACs will concentrate on functions related to coordination and specialization in EU affairs, acting as hubs of expertise for parliamentary chambers. This also affects committee-party relations as close cooperation between the representatives of different political parties within EACs creates the conditions for cross-party contacts and strategic alliances, allowing MPs to escape from strict partisan control and making committees independent political actors.

It is shown above how the concepts of 'party cartel' and 'EU political cleavage' might explain the general pattern of a parliament's reaction to the new opportunity structure. They cannot, however, provide an explanation for how different types of parliamentary actor behave in the post-Lisbon political environment. The abovementioned insights from the academic literature help to establish a set of expectations about the behaviour of parliamentary administrators, committees and political parties in the new opportunity structure:

1. Parliamentary administrators will exert greater leverage on the outcome of the scrutiny process and on shaping parliamentary rules and procedures as the new opportunity structure creates greater demands for information and expertise within national parliaments (Christiansen, Högenauer and Neuhold 2014);

2. Although all political parties will start to address EU issues, it is expected that opposition parties will be more interested than governing parties in using the new opportunity structure because the Lisbon Treaty provides them with additional instruments to redress the power imbalance (Holzhacker 2002, 2005);

3. Opposition parties in countries with minority governments will be more active in using the new opportunity structure than opposition parties in countries with majority or coalition governments, as in the former case the government is much more susceptible to following the demands of the opposition in order to secure stable conduct of its policies (Holzhacker 2002, Bergman 2000);

\footnotetext{
${ }^{52}$ The three perspectives on parliamentary committees are classified as information, distributive and partisan. For a more nuanced description of these approaches see Martino (2006), Whitaker (2005) and Fujimura (2012).
} 
4. By creating greater demands for information, expertise and coordination, the new opportunity structure allows parliamentary committees (both EACs and sectoral committees) to escape partisan control and develop an independent political profile (Shepsle and Weingast 1981, Krehbiel 1991).

\subsection{Research design}

In order to gather and assess information that can validate or falsify the abovementioned expectations, I focus on three qualitative cases studies. These address the interaction between parliamentary actors, in the aftermath of the Lisbon Treaty, from different national parliamentary traditions. No attempt is made to quantify either the input of distinct groups of parliamentary actors or parliaments' political influence. Despite the widespread use of quantitative approaches and formal models in legislative studies (Shepsle 2002), 'thick description' and tracing the patterns of legislative participation in a policy process remain important, as a prerequisite for the development and testing of formal models and generalizations drawn from quantitative large $\mathrm{N}$ research (Arter 2006b, p.479).

The research is inductive, meaning that it is not focused on testing a set of theoretical propositions ${ }^{53}$. "Inductive research starts from an empirical investigation of the phenomenon of interest" (Merton 1968 quoted in Héritier 2008, p.64). The key argument for adopting an inductive research design is the attempt to study political processes from the perspective of the actors involved, which enables investigation of the scrutiny of EU affairs at the 'micro level' of parliamentary politics.

Case studies are especially suitable for studying political processes from the perspective of the actors involved. Ultimately, as George and Benett (2005, p.45) argue, case studies are the methodological tool required to investigate the causes of social processes or phenomena for which no precise datasets are available. Despite the fact that in contrast to quantitative research, qualitative case studies provide limited opportunities for generalization, they allow a researcher to develop an in-depth understanding of the political process under investigation. Choosing a small number of cases makes it possible to reconstruct the scrutiny process and assess the involvement of various types of parliamentary actors in greater detail.

\subsection{Case selection with regard to national parliaments}

Conducting case selection on the basis of 'most different' or 'most similar' research design (Peters 1998, George and Bennett 2005, Gerring 2007) is problematic within the

\footnotetext{
${ }^{53}$ Although this dissertation analyzes a number of expectations about the behaviour of parliamentary actors, they are not derived from a distinct theory (or set of theories) but are based on observations from academic literature. Given the fact that this dissertation is not engaged in explicit theory-testing, I consider the research design of the study to be inductive
} 
framework of this thesis. For the latter strategy, cases have to be similar in almost all of their characteristics except for the variables of interest. An example could be a comparison of Danish and Finnish scrutiny systems which are very similar but differ somewhat regarding the involvement of standing committees in EU affairs. However, adopting a 'most similar' research design could compromise external validity, as it would not capture the variety of existing types of parliamentary scrutiny. 'Most similar' research design implies that only one scrutiny type (either mandating or document-based scrutiny) or group of national parliaments (for example Nordic parliaments) is selected. This case selection strategy would limit the possibility of generalization as it does not capture the variation of formal rules and practices amongst national parliaments.

Gerring (2007, p.139) argues that in the 'most different' case selection strategy, one identifies cases where "just one independent variable $\left(\mathrm{x}_{1}\right)$, as well as the dependent variable (y), co-vary, while all other plausible factors $\left(\mathrm{x}_{2 \mathrm{a}-\mathrm{d}}\right)$ show different values". The 'most different' research design attempts to find a relationship among factors "that can survive being transported across a range of very different countries" (Peters 1998, p.41). In other words, for the 'most different' case selection strategy to be chosen the outcome of a process under investigation should be similar despite all the differences between the cases considered. Nonetheless, it cannot be supposed in advance that all national parliaments will use the new 'opportunity structure' to the same degree in order to become more active and influential in EU affairs. For example, Raunio (2009) argues that although all national parliaments have created European Affairs Committees, there is no conformity in their behaviour. Hence even if similar institutional solutions are adopted to address the challenge of European integration, they do not have a similar effect in various national parliaments. Differences in national parliamentary traditions and the vested interests of political actors can account for variations in the use of new competences. Therefore, the 'most different' research design cannot be applied in this thesis.

All the above implies that the research design should reflect the diversity of national parliament types and the fact that external conditions (the Lisbon Treaty provisions) are formally equal for all of them. In such a situation, the 'diverse' case selection strategy appears to be the most suitable (Gerring 2007, p.97; Seawright and Gerring 2008, pp.300-301; Rohlfing 2012). This case selection method illuminates the full range of country variation in terms of parliamentary strength, which enables study of the behaviour of parliamentary actors in a variety of institutional contexts. "Diverse cases are likely to be representative in the minimal sense of representing the full variation of the population, although they do not necessarily mirror the distribution of that variation in the population" (Seawright and Gerring 2008, p.297). Nonetheless, drawing on Hawkins $(2009$, p.56, 62-63), it could be argued that conclusions about the interaction of parliamentary actors in the three selected case studies will be of a more probabilistic 
than a deterministic nature ${ }^{54}$. Gerring (2007, p.49) develops this argument, claiming that case study researchers are reluctant "to invoke determinate causal propositions with great reach". Despite the fact that some general trends in the interaction of political parties, parliamentary administrators and committees can be discerned, they will not necessarily be present in all national chambers to the same extent.

The fact that 'parliamentary strength' remains a contested concept is reflected in the high number of existing classifications of national parliaments. Maurer and Wessels (2001, pp.33-36), for example, developed a classification of parliaments according to their input into government policy on the EU as well as their activity at the EU level, although their typology does not take Central and Eastern European states into account. A typology suggested by Raunio (2005) suffers from the same shortcoming. The study by Sieberer (2011), who evaluates the different dimensions of parliamentary strength, unfortunately also takes only West European states into account. The study conducted by Fish and Kroenig (2009), the Parliamentary Power Index (PPI), is based on a much larger sample, going beyond the EU to include parliaments in Asia and Africa. The PPI is not used as a basis for case selection, however, for a number of reasons. First, the survey questions are heavily biased towards formal provisions and do not necessarily reflect the 'real' role of a parliament in a given political system ${ }^{55}$. Second, the large $\mathrm{N}$ approach disregards differences between parliaments in a similar regional group. For example, compared to some African or Asian legislatures, almost all the EU member states achieve high scores, but the $\operatorname{scores}^{56}$ for Sweden (0.72), the Czech Republic (0.81) and Romania (0.72) clearly disregard the differences between the respective parliamentary chambers.

It is the strength of parliaments in domestic politics that is used as the criteria for case selection. Karlas (2011) and Winzen (2013) argue that it is one of the key factors that could determine the influence of national parliaments in EU affairs. Auel, Rozenberg en Tacea (2015a), however, do not support this claim. It should be noted that for their calculations they have used the abovementioned Parliamentary Power Index (PPI) which may not adequately reflect the political leverage of European parliaments. Auel, Rozenberg and Tacea (2015a) consider that 'domestic' parliamentary strength reflects the formal rights of parliament and not necessarily their activity. They postulate that there seems to be a difference between the parliaments of Western European states and those of 'new' EU members. The former exhibit a positive correlation between domestic powers, budgetary competences and activity in EU affairs. Yet domestically strong

\footnotetext{
${ }^{54}$ Lieberson (in Gomm, Hammersley and Foster 2000), however, argues that small N case studies which use 'most different' and 'most similar' research designs cannot operate if they consider the relationship between explanatory factors to be of a probabilistic nature. See Gerring (2007) for a development of Lieberson's arguments.

${ }^{55}$ At the same time it should be noted that Fish and Kroenig combine formal and informal institutions in their assessment, as well as expert opinions. For a review of their work see Desposato (2012), Kroenig and Fisch (2012) and Melia (2010).

${ }^{56}$ From 0 to 1 , with 1 denoting maximum parliamentary strength,
} 
Central and East European parliaments are not necessarily influential in EU policies.

Although the exact impact of 'domestic' parliamentary strength on performance of national chambers in EU affairs remains a matter of debate, I do not consider it legitimate to exclude this explanatory variable altogether. Moreover, the findings of Auel, Rozenberg and Tacea (2015b), who address both institutional strength and activity of parliaments in the field of EU affairs, confirm the validity my case selection. Sweden, Czech Republic and Romania represent various degrees of parliamentary strength in EU affairs: the Swedish Riksdag is the most influential, followed by the Czech and Romanian parliaments respectively.

Ultimately, the selection of national parliaments for this dissertation was conducted on the basis of a typology developed by Magone (2011, pp.201-204), which includes both 'old' and 'new' member states. Parliaments from Central and Eastern European and the Balkans are placed at the lower end of the parliamentary strength spectrum. Nordic parliaments, albeit with different rankings, are considered the strongest, while of all the EU member states the parliaments of Romania and Bulgaria are considered the weakest. Based on Magone's classification, Sweden was selected as an example of a strong parliament, the Czech Republic as an example of a medium-strong parliament and Romania as an example of a weak parliament. Given the fact that Gomm, Hammersley and Foster (2000, p.108) argue that the study of cases that "cover the extremes of expected relevant heterogeneity within the population" is one of the key conditions for being able to generalize from small $\mathrm{N}$ studies, the case selection adopted allows the drawing of a number of conclusions about the evolution of national parliamentary bodies in the post-Lisbon political environment.

This case selection was checked against the 'budget power index' (Wehner 2006). A parliament's standing in a political system is arguably roughly commensurate to its capacity for financial scrutiny. The requirement for legislative approval of financial measures is the central tenet of a democratic system and is one of the key functions of any parliament. Romania was not included in the sample for Wehner's study, but his research confirms that Sweden can be considered a strong, influential parliament while its Czech counterpart enjoys much less political clout.

In addition to representing the whole spectrum of 'parliamentary strength', Sweden, the Czech Republic and Romania also reflect the wide range of political regimes and relations between upper and lower chambers. Nonetheless, it should be noted that the distinction between different types of political systems (majoritarian or consensusorientated) or variants of bicameralism (Guasti 2011) did not play a major role in case selection $^{57}$. These are treated more as framework conditions and not as explanatory variables.

\footnotetext{
${ }^{57}$ Neuhold and de Ruiter (2010) have shown that consensual political systems do not necessarily favour committee based scrutiny of EU affairs, while majoritarian political systems do not automatically lead to plenary based analysis of EU issues. The relationship between types of political system and approaches to parliamentary scrutiny of EU affairs is not linear and merits further investigation.
} 
Note that the dichotomy between 'old' and 'new' member-states is not a selection criterion. In fact Central and East European member-states adopt scrutiny types that are similar to those of the West European countries. Moreover, the parliaments of both 'old' and 'new' member-states experience that strong formal scrutiny rights are not always matched by respective levels of activity in EU affairs. The idea behind taking two out of the three cases from Central and Eastern Europe is that there is little information on the application of scrutiny rules in these parliaments. This does not allow for a comprehensive understanding of the impact of European integration on national parliamentary structures. Selecting just three cases allowed, however, for a more in-depth assessment of the political development of respective national parliaments.

It should be acknowledged, however, that the evolution of the Swedish, Czech and Romanian parliaments in the post-Lisbon environment cannot comprehensively represent the adaptation of all strong, medium-strength and weak parliaments to the challenges of EU integration. As Schofield (in Gomm, Hammersley and Foster 2000, p.75) stress, generalizations, in the sense of producing broadly applicable laws, are difficult to draw from small N case studies. On the other hand, Flyvbjerg (2011, p.304-305) claims that generalizations can still be drawn from small $\mathrm{N}$ case studies. Analysis of the three abovementioned parliaments can indicate trends in the functioning of specific groups of parliaments in the new political environment. In other words, the findings may not be fully representative of the processes that take place in each and every strong, mediumstrength and weak national chamber. The selection of just three case studies cannot take full account of all national parliamentary contexts and traditions, which, according to Hoing (2013), will increasingly diversify in the aftermath of the Lisbon Treaty and the Eurozone crisis. However, small $\mathrm{N}$ case studies can provide a detailed and in-depth understanding of political practices. These insights can be addressed and tested within a larger case sample.

\subsection{Case selection with regard to EU proposals}

The choice of EU proposals scrutinized by national parliaments was based on exploratory interviews with 12 representatives of national parliaments carried out in Brussels in October to December 2010, and information retrieved from the IPEX ${ }^{58}$ database. These parliamentary representatives, being constantly in contact with their respective domestic chambers, can be considered key informants on national parliamentary scrutiny of EU affairs. The representatives were asked which legislative or non-legislative proposals from the EU had been important for parliamentary debates on EU affairs in 2010, and had the potential to affect domestic electoral politics. Drawing on their responses, two documents were selected:

a. the Green Paper towards an adequate, sustainable and safe European pension system (COM 2010 0365);

\footnotetext{
${ }^{58} \mathrm{IPEX}$ is an inter-parliamentary database dedicated to the scrutiny of the EU documents.
} 
b. the Proposal for a directive on the conditions of entry and residence of third country nationals for the purpose of seasonal employment (COM 20100379 final).

Analysing the results of the scrutiny process of the two documents helps us to understand how national parliaments perceive and address two core domains of EU policymaking - the single market and the area of justice, security and liberty (JLS) ${ }^{59}$. The European Commission considers that pension policy should be subject to the 'four freedoms', hence analysing the Green Paper on pensions helps us to understand how national parliaments scrutinize proposals related to the single market. The Proposal on seasonal migrants addresses the conditions under which third-county nationals can enter the European Union, an issue that falls within the JLS domain. Despite the fact that it is generally considered that specialization in EU affairs does not increase the chances of MPs being re-elected (Auel and Raunio 2011, p.14), the topics of pensions and migration are considered important to all strata of voters. These topics are seen as 'critical cases' for the assessment of parliamentary scrutiny of EU affairs. In these particular cases, MPs can be expected to have more incentives to invest time in the scrutiny of EU affairs and to combine both the EU and the domestic levels in their analysis. These issues also fit within domestic political divisions (for example, the left-right cleavage) so that various national political actors can use the abovementioned EU proposals to affect the domestic status quo in one way or another. These mobilized national actors would have an interest in 'transposing' the EU suggestions into the domestic political debate $^{60}$. Given that pension and labour migration regimes are already undergoing profound transformation in the member states, EU proposals are also in line with topical debates at the national level.

The selection of policy cases does not privilege 'administrative' actors (parliamentary staff) over 'political' actors (MPs). Firstly, the new Lisbon Treaty provisions can be activated only if MPs are interested in acting on EU issues, for example for electoral goals. Pensions and labour migration issues offer them an opportunity to address both domestic agenda and EU policies. During exploratory interviews with representatives of national parliaments in Brussels the interviewees admitted the saliency of economic topics but stated that precisely due to the technical complexity of this issue MPs may be discouraged to invest time into its scrutiny. Moreover, Auel and Höing (2014) have shown that national parliaments consider the Eurozone crisis as 'business as usual'; there is a strong correlation between activity related to crisis and activity in other EU policy domains. The Eurozone economic crisis has been actively discussed in plenary debates but in terms of the wider parliamentary engagement in EU affairs it has not

\footnotetext{
${ }^{59}$ On the crucial impact of the JLS on the way member states address control of territory, civil rights and law enforcement see Lavenex and Wallace (2005), Monar (2001, 2010) and Boswell (2010), among others.

${ }^{60}$ This argument is based on the observation of Raunio (2011, p.319) who argues that "political parties may be more prepared to have public debates about EU policies than about integration (more or less EU), particularly if these policies can be incorporated into the cleavages structuring domestic party competition (mainly the left-right dimension)"
} 
changed much. Hence, not including economic affairs as one of my policy cases does not seem to bias the research findings.

Secondly, it is considered that administrators can exert the most leverage in highly technical and complex issues (DeGregorio 1994; Baekgaard, Blom-Hansen and Serritzlew 2014). As will be shown in Chapter 4, reforms in the policy sectors of pensions and labour migration are also very technical; parliamentary staff can have an impact on the scrutiny process by advising specific policy solutions or raising the awareness of MPs about technical aspects of EU proposals.

The fact that two different types of legal documents (one legislative proposal and one strategic policy document) were selected does not constitute a problem for the research design. This selection enables an understanding of whether the scrutiny of legislative proposals and non-legislative strategic documents from the EU is approached differently by various parliamentary actors. In theory, parliaments may have a better chance of influencing EU policies and their respective national governments if they get involved at the early stages of drafting a piece of legislation. Involvement in the scrutiny of a Green Paper is the first stage in the EU policy-making cycle when national parliaments can try to shape the content of a proposal: either acting as a stakeholder in the consultations initiated by the European Commission or through the Early Warning System. Green papers are a crucial non-legislative instrument of the European Commission. They serve as a stepping stone for the development of legislative proposals, in contrast to the $\mathrm{OMC}$ or other non-legislative instruments of the European Commission. This means that scrutinizing a Green or White Paper provides a national parliament with greater leverage as it would be able to act as an agenda-setter and frame a debate on legislative activities of the European Union in a way that would most fully reflect its own interests. Given that Green or White Papers can develop into full-scale legislative proposals, national parliaments that devote time to the scrutiny of strategic documents arguably have a greater chance of 'uploading' their views into the text of a legislative proposal. Ultimately, having a non-legislative document in the research sample allows to understand whether this opportunity for early involvement is actually used by national parliaments. In order to make such an assessment access to data on parliamentary activity in EU affairs is required

\subsection{Data gathering}

Empirical data was gathered through access to primary sources as well as elite and expert interviews. A number of primary sources were used:

- European Commission legislative and non-legislative documents;

- European Parliament resolutions and committee reports;

- Documents from national parliaments, such as rules of procedure, resolutions (at the plenary and committee level) and minutes, draft legislation dealing with the scrutiny procedure; 
- National Constitutional acts and the rulings of Constitutional Courts;

- Reasoned opinions of national parliaments, their contributions to the 'political dialogue' with the European Commission and collective subsidiarity checks.

Interviews are another important source of information, as they can provide detailed accounts of events that help to reconstruct the causal chain and check the putative value of explanatory factors (Tansy 2007). Interviews also help to integrate the perspectives of different actors, providing a clearer and more reliable depiction of the social process under study. The research is based on 'systematizing expert and elite interviews', the focus of which is "the capacity to provide researchers with facts concerning the question they are investigating" (Bogner and Wenz 2009, Littig 2009). The ultimate goal of these interviews is to reconstruct the 'objective knowledge' about a policy field or a certain social process through open questions ${ }^{61}$.

A large number of interviews (165) were conducted in order to obtain first-hand information from practitioners and domestic experts on the conduct of parliamentary scrutiny of EU affairs. The respondents were grouped into several broad categories:

- Members of EACs or other standing committees and MEPs;

- Parliamentary staff (committee administrators, members of various auxiliary expert or administrative services);

- Stakeholders and NGOs;

- Experts and journalists;

- Governmental officials and representatives of the European Commission.

In principle, respondents had to be either directly engaged in the scrutiny of EU affairs or able to provide information on actors and processes in domestic politics or the policy areas of pensions and labour migration. Apart from selecting respondents through official records, for example the lists of committee members or civil servants available on parliamentary websites, "snowball sampling" was also used. Snowball sampling is a type of purposive sampling, an approach where not the entire population of cases but specific features or characteristics of units are important. Snowball sampling is used not only to obtain information but also to trace potential new respondents (Kemper, Stingfield, Teddlie 2003). Snowball sampling helps overcome one of the key challenges of elite and expert interviews - getting access to respondents. It is very useful for reaching small, dispersed or hard to access populations (Ritchie, Lewis and Elam 2003). Contacts with the representatives of national parliaments proved invaluable for establishing links with staff members in domestic legislatures. The representatives of national parliaments in Brussels were the key informants on many occasions. Snowballing was extremely useful in tracing respondents who had moved to different jobs or retired, for example, former MPs or parliamentary staff members. This method also proved very useful in selecting local experts and journalists. An additional way to select respondents from the

\footnotetext{
${ }^{61}$ There is a large body of literature that addresses the methodological and practical challenges of conducting interviews. See, for example, Dexter 1970, Ostrander 1993, Zuckerman 1972, Richards 1996, Rubin and Rubin 2004, Kvale 2007, Weiss 1994, Berry 2002, Lilleker 2002
} 
academic or NGO environment was by consulting relevant publication databases (EBSCO, CEEOL etc.) or the webpages of key national think tanks ${ }^{62}$.

Interviews were conducted in several stages. As noted above, exploratory interviews with the representatives of national parliaments in Brussels were carried out in October to December 2010. Their main goal was to determine the countries and policy cases that were to be researched in the thesis. Moreover, these interviews provided first insights into how national parliaments make use of the Lisbon Treaty provisions. The second round of interviews was executed in September to December 2011 and was focused on the EU-level actors: members of the European Commission; members of the European Parliament and their assistants; officials from the selected Permanent Representation offices; and representatives of the national parliaments of Sweden, the Czech Republic and Romania. These interviews enabled an assessment of whether national parliaments were developing links with EU-level institutions in order to affect the scrutiny process for the selected EU proposals. Three successive rounds of interviews were conducted in Stockholm, Bucharest and Prague, to obtain information from national MPs, domestic experts and parliamentary staff. These interviews were conducted between late February 2012 and mid-May 2012. Three weeks were spent in Stockholm and Prague, respectively, and two weeks in Bucharest. Several follow-up interviews were conducted between June and October 2012. An additional round of interviews was conducted in Prague in May 2013 (one week) to assess developments in the Czech scrutiny system. The final interviews were conducted by telephone in September to November 2013, to check on developments in the parliaments of Sweden and Romania.

All 165 interviews were anonymous in order to ensure confidentiality. On average, the interviews lasted 45 minutes - the shortest being 15 minutes, the longest taking 2 hours. Transcripts were made of all the interviews. Interviews were recorded if the respondents agreed to such a request. A large number of Swedish ${ }^{63}$ as well as the majority of $\mathrm{Czech}^{64}$, Romanian ${ }^{65}$ and Brussels-based ${ }^{66}$ interviews were recorded.

The reliability and verification of interview data is one of the main challenges of qualitative social science research. The high number of interviews recorded in the course of the fieldwork helps support the research findings as, for example, both quotations and the author's interpretation can be easily checked ${ }^{67}$. Notes were taken even during the interviews that were recorded in order to keep track of a respondent's an-

\footnotetext{
${ }^{62}$ The lists and rankings of think tanks in the EU were taken from the database of the "Think tanks and civil society program' at the University of Pennsylvania. See http://www.gotothinktank.com.

${ }^{63} \mathrm{~S} 1-3, \mathrm{~S} 5-27, \mathrm{~S} 29-37$.

${ }^{64} \mathrm{C} 1-3, \mathrm{C} 6, \mathrm{C} 7 \mathrm{~b}, \mathrm{C} 8, \mathrm{C} 11, \mathrm{C} 13$; C15-16, C18-19, C22, C24, C26-29, C31a, C32-C36, C39.

${ }^{65} \mathrm{R} 2-\mathrm{R} 3 \mathrm{a}, \mathrm{R} 4-\mathrm{R} 12, \mathrm{R} 14-\mathrm{R} 18 \mathrm{a}, \mathrm{R} 19-\mathrm{R} 21$.

${ }^{66}$ B1a - B6b, B7-11, B14, B16a, B18, B26, B29-30.

${ }^{67}$ Apart from one occasion, respondents were not offered a chance to read the transcripts of the interview. Checking post-interview transcripts by a respondent can help sustain the validity of the data. At the same time, however, a respondent might influence the research by changing the transcript in one way or another. In cases where additional information was required, it was obtained by a follow-up meeting or an information request.
} 
swers, adjust questions and demonstrate the interviewer's interest. A number of unrecorded interviews were conducted by telephone, but face-to-face interviews proved to be a richer source of data. Apart from having more opportunities to establish a 'rapport' between the respondent and the interviewer, face-to-face interviews allow quicker and better reactions to the answers by a respondent.

The majority of interviews were conducted in English. R19 was conducted in French, R2 in German and C22 partly in German and partly in English. Respondents were provided with a draft questionnaire consisting of four or five questions, although their content and focus obviously varied from one respondent group to another. More general questions were addressed first to establish a rapport with a respondent. More specific and sensitive issues were raised later. The same order of the questions was not always followed, as the interviewer tried to provide respondents with maximum freedom to express their views. The interviewer also had a more extensive questionnaire, where 'probes' were recorded which could be used to adjust the course of an interview or address issues not mentioned by a respondent. The probes were used either to encourage respondents to go into more depth on certain issues, ${ }^{68}$ or to gauge their assessment of established concepts, an example of the latter being a question posed to academic experts and NGO practitioners about the validity of the 'party cartel' thesis. Information from other respondents was often checked using probes ${ }^{69}$. There was also a strategy to ask sensitive questions, for example, to check the information on the purported influence of a political party in a committee secretariat in a given national parliament. At the end of the interview, respondents were asked whether they would like to address any issues that had not been raised during the interview or to add anything. The templates of the questionnaires are attached as Annex 2. It is evident that simply retrieving information from interviews and primary sources is not enough to answer the research question. That requires instruments of interpretation and analysis, which are addressed below.

\subsection{Data interpretation through process-tracing}

The main method of data interpretation used in the thesis was process-tracing, which explains social phenomena by assessing causal links between the stages and critical junctures of a social process (George and Benett 2005, p.6). Process-tracing helps to order interview-data by providing a thick empirical description of a political process, which also makes research results more relevant and reliable (Checkel 2005, 2006) ${ }^{70}$. As Venesson (2008, p.224) puts it, "process-tracing can be fruitfully used in both posi-

\footnotetext{
${ }^{68}$ For example: "Apart from revising the rules of procedure, have there been any transformation in the staff work instructions and regulations or new ideas introduced in order to adapt the scrutiny system to the demands imposed by the Lisbon Treaty?"

${ }^{69}$ For example: "One of my respondents has mentioned that $\mathrm{X}$ took place due to Y. In your opinion, is this a correct description of what was really happening?"

${ }^{70}$ For a contemporary discussion of process-tracing see the contributions to European Political Science, 12:1
} 
tivist and interpretivist research designs, allowing researchers to combine a positivist and an interpretivist outlook in case study research". Process-tracing is different from simple storytelling because it is focused, that is, it deals only with specific aspects of a phenomenon, and is driven by a theoretical or conceptual framework. Its ultimate goal is to produce a narrative explanation of a causal path that leads to a specific outcome (Venesson 2008, p.235). This is achieved by interviewing the actors involved in the policy process, juxtaposing their 'evidence' and paying special attention to occasions where their 'testimonies' contradict each other. Process-tracing requires triangulation and cross-checking of all sources of information. This allows a reconstruction of the causal relations and avoids bias due to overreliance on interviews or other types of information source. The use of analytical constructs such as 'opportunity structure', 'voice', 'threat of issue exit' and 'neglect' also helps to go beyond the mere recital of facts to move to another 'level of abstraction', depicting not only agency but also the structural factors of the policy process.

Within the framework suggested by Blatter and Haverland (2012, pp.79-143), the thesis is based on causal process-tracing, as the research question addresses "the many and complex causes of a specific outcome" with the final aim of understanding how exactly each of the causes contributed to the outcome. According to the framework of Beach and Pedersen (2013, pp.63-68), the dissertation is based on 'explaining-outcome' process-tracing. It is focused not on theory-building or theory testing but on providing a minimally sufficient explanation of an outcome in a particular case. As the thesis attempts to assess through which mechanisms national parliaments react to the Lisbon Treaty and how the relationship between parliamentary actors has changed, this method of data-interpretation appears to be the most suitable. Within causal process-tracing it is by and large accepted that several divergent causal pathways can lead to a hypothesized outcome. This is indeed the case as parliaments are adapting to the provisions of the Lisbon Treaty according to their domestic political context. With causal process-tracing, no reference is made to independent or dependent variables, or their co-variation. Instead, the focus is put on the "temporal order of phases of transition and their development" (Blatter and Haverland 2012, p.114). The problem of equifinality, a situation in which a specific outcome can be the result of several distinct processes, is fully taken into account as the research does not intend to consider the 'share' of each factor or mechanism, but strives to understand how and which mechanisms have played a crucial role. The ample use of quotations in the thesis provides support for the way causation was interpreted on the basis of interview data. The initial assessment of data is focused on parliamentary practice in Sweden, the Czech Republic and Romania, while Chapter 8 combines country-specific information in order to provide some generalizations about the behaviour of distinct groups of parliamentary actors and identify trends in the evolution of scrutiny systems.

As noted above, generalization from small $\mathrm{N}$ case studies can be challenging. Causal process-tracing, however, does not aim for comprehensive generalization to a 
larger population of cases. Instead, it focuses on 'possibilistic generalization', defining combinations of causal conditions that make a specific outcome possible (Blatter and Haverland 2012, p.31, 82, 136-137) ${ }^{71}$. In other words, on the basis of analysing the interaction of parliamentary actors in Sweden, the Czech Republic and Romania, it is possible to identify a number of trends in the evolution of parliamentary institutions in the new 'opportunity structure' or factors that affect parliamentary behaviour. Nonetheless, these trends will be present to varying degrees in every national parliament in the EU, depending on the domestic context.

Like any research method, process-tracing is not without its limitations and challenges. Despite the fact that it is considered to be an adequate tool for addressing the research question of the thesis, it is important to be aware of its limitations. Section 2.11 addresses the challenges associated with the suggested research design.

\subsection{Limitations and challenges of the research design}

One of the key challenges of small $\mathrm{N}$ qualitative research is the ability to make generalizations. Arguably, quantitative research based on QCA and regression (Saalfeld 2005; Wessels 2005; Hamerly 2007; Karlas 2011 and 2012; Pahre 1997; Winzen 2012) is more suitable for making overarching generalizations about the evolution of parliamentary scrutiny systems ${ }^{72}$. However, the rankings and criteria used in such studies often only reflect formal scrutiny rights and pay less attention to political practice. By contrast, small $\mathrm{N}$ qualitative case studies provide a detailed and in-depth understanding of specific political processes, for example, the interaction between different groups of parliamentary actors during the scrutiny of EU affairs, which can hardly be matched by quantitative approaches. Moreover, the aim of the dissertation is not to develop overarching generalizations about the patterns of interaction between parliamentary actors that will be equally present in all the national parliaments of the EU member states. The thesis aims to indicate and explain tendencies in the relations between political parties, parliamentary administrators and committees, although, as noted above, different national parliaments are likely to experience these tendencies to varying degrees.

Another challenge for the dissertation is connected to the method used to analyse interview data - process-tracing. Collecting and cross-checking evidence, isolating causal mechanisms and generalizing from small $\mathrm{N}$ studies all raise aspects of criticism of the process-tracing methodology (Dür 2008, Venesson 2008, Hawkins 2009). One of the methods proposed to cross-check data for process-tracing is the so-called EAR technique (ego-perception, alter-perception, researcher's analysis) (Arts and Verschuren 2005). This assigns ordinal measurements to the level of actor involvement in a particu-

\footnotetext{
${ }^{71}$ Beach and Pedersen (2013, p.70) argue that 'explaining outcome' process-tracing is less focused on making generalizations and more attuned to explaining the outcomes of particular processes.

${ }^{72}$ On the opportunities to overcome the rigid divide between quantitative and qualitative approaches in social sciences see, for example, Brady and Collier (2010).
} 
lar policy process, depending on the 'extent of the actor's goal achievement, extent to which this goal achievement can be ascribed to the actor's own actions and political relevance of the policy outcome". This method has its drawbacks, however, linked to respondents' occasional inability to recall past events or to provide estimates of other actors' actions. It was therefore not used in the current study.

Potential bias in the selection of the EU policy proposals scrutinized by national parliaments can also be considered a limitation of the thesis research design. It could be argued that the choice of EU proposals in the domain of labour migration and pensions reflects policy spheres in which the competences of the EU institutions are weak. Moreover, greater EU presence in these policy domains is likely to be fiercely resisted by member states as an increased role for the EU in these sectors touches on core national competences. Hence, it could be argued that instead of using parliamentary scrutiny to change domestic policy regulation, national political actors will simply use it to prevent further growth of EU competences, regardless of the content of the policy solutions proposed by the European Union. It should be noted, however, that resistance to the growth of EU competences can take place in policy domains where the role of EU supranational institutions has long been established, for example, the Single Market. Furthermore, as is demonstrated below, the content of the Green Paper on pensions and the Proposal for a directive on seasonal migrants can be addressed by both Eurosceptic and pro-European political actors, depending on which aspect of the proposal is under scrutiny.

As argued in Chapter 1, contemporary studies of European integration and national parliaments have increasingly turned to an analysis of their representative and communicative functions (Auel and Benz 2005; Auel 2007), addressing topics such as media coverage of the EU and the role of EU issues in plenary debates and constituency service. This dissertation, however, focuses on the legislative functions of national parliaments, which could be considered a drawback of the research design. The novelty of the provisions of the Lisbon Treaty is the formal right of national parliaments to participate in the legislative process through the Early Warning System and a number of other mechanisms. Obviously, the communicative functions of national parliaments in EU integration have been given a boost by the Lisbon Treaty, but their ability to influence EU legislation either directly or through domestic executives is likely to be the crucial test for the Lisbon Treaty provisions, as it would allow a direct connection between domestic and EU politics.

The limits of comparing the pre- and post-Lisbon environment should also be taken into account. For example, a direct comparison between the two selected EU proposals and their pre-Lisbon homologues is quite complicated. In the case of the Proposal for a directive on seasonal labour migrants, the only directly comparable legal text dates back to 1994. The Proposal can also be compared to the Hague programme or the European Commission's communication of 2005, “A policy plan on legal migration", but the scope of these documents is much broader. In the pre-Lisbon period national parlia- 
ments were less active in deliberating on EU policies, which makes a direct comparison problematic. Despite the lack of clear analogues of the evaluated documents, however, it is still possible to discern differences between pre-Lisbon and post-Lisbon practice, drawing on the opinions of practitioners, experts and key stakeholders. It should also be acknowledged that the timeframe adopted in the thesis makes it more difficult to comprehensively analyse the effect of national general elections on parliamentary scrutiny of EU affairs. Given the fact that only Romania held a general election between 2011 and 2013, when the bulk of the empirical information was gathered ${ }^{73}$, it is difficult to draw systematic conclusions about the effect of elections on parliamentary debates on EU issues. Moreover, the role of the EU in national party programmes during general elections is largely beyond the scope of the thesis. Nonetheless, whenever possible the impact of national elections on parliamentary scrutiny of EU affairs is gauged through interviews with relevant political actors. Too little time has elapsed to fully assess the impact of the Lisbon Treaty, but it is precisely this situation that offers opportunities to directly trace the changes brought about by the Treaty, gaining a first-hand account of the ongoing political transformation. Although drawing a clear comparison between the pre- and post-Lisbon political environments may be complicated, it is possible to identify key stages and documents that mark the growing involvement of national parliaments in EU integration.

\footnotetext{
${ }^{73}$ The Czech Republic held elections in late October 2013, before the expiry of the parliament's four-year term, after the resignation of the government in May 2013 due to a series of political scandals
} 


\section{CHAPTER 3: The evolution of the role of national parliaments in the process of $E U$ integration}

This chapter elaborates on how the role of national parliaments was codified in EU primary law during different stages of the EU integration process. The impact of the Single European Act and the treaties of Maastricht and Amsterdam on the ability of national parliaments to participate in the EU policymaking process is examined. The chapter also addresses the debates on the role of national parliaments in the Convention on the Future of Europe. It explains which ideas voiced in the Convention on the Future of Europe were incorporated into the Treaty establishing a Constitution for Europe and, after its rejection in Dutch and French referendums, in the Lisbon Treaty. Finally, the chapter identifies the mechanisms enshrined in the Lisbon Treaty that allow national parliaments to exert greater influence over EU affairs at both the domestic and the supranational levels.

\subsection{National parliaments and European EU integration before the Maastricht Treaty}

According to Norton (1996), the role of national parliaments in EU integration in the period from the 1950 s to the early 1980 s can be considered one of 'limited involvement'. Traditionally, this is explained by the spread of qualified majority voting (QMV) as well as the introduction of direct elections to the European Parliament. The increased use of QMV made it difficult to hold ministers accountable as they could be easily outvoted in the Council of Ministers regardless of the existence of a potentially stringent mandate from their national parliament. The introduction of direct elections to the European Parliament, according to Agostini (2001), limited the access of national parliamentarians to the EU level and left them increasingly detached from EU issues. In general, national parliaments had neither the interest nor the resources to address EU topics in detail.

It is noteworthy that within the abovementioned time period EU-level institutions such as the European Commission and the European Parliament, and not the member states, were the first to address the role of national parliaments in the EU political system, albeit by framing the issue in a 'negative way'. For example the so-called Vedel report (EC Commission 1972, p.32) stressed that the EU had to develop its own distinct mechanisms for democratic legitimacy. It stated that "as the Community extends its powers, the national parliaments at the same time lose legal and defacto powers" (EC 
Commission 1972, p.32). Enhancing national parliamentary control over member states' governments was not considered a viable solution as it could make reaching consensus in the Council even more complicated. "The collective nature of this process ${ }^{74}$ and the irrevocable character of the resultant decisions do, however, impede the effective control which the various national parliaments could exercise.... Any attempts to establish an effective control of this kind would involve a danger of the national parliaments binding the governments by instructions given in advance; this would make the search for agreement within the Council even more difficult and more laborious than it is now" (EC Commission 1972, p.33). The European Commission suggested that this loss of parliamentary powers at the national level could be compensated for primarily by increasing parliamentary control at the EU level. This implied that the logic of EU integration made the increasing marginalization of national parliaments somewhat irrevocable. Only the European Parliament could provide the necessary instruments of democratic control, although the need for close cooperation between national parliaments and the European Parliament was stressed: "If the national parliaments were given reliable means of communicating with the European institutions through the European Parliament, this would prevent any weakening of national democratic control while avoiding the dangers of exaggeration" (EC Commission 1972, p.66).

Since the 1980s, the marginalization of national parliaments in the domain of EU affairs has not seemed irreversible, as domestic chambers started to exhibit greater specialization in EU matters, became more active and attempted to establish stronger contacts with members of the European Parliament (Norton 1995). A number of factors can explain this change in parliamentary attitude to the EU. First, as a number of authors argue, this was a direct consequence of the accession of the Eurosceptic United Kingdom and Denmark (Norton 1995, Raunio 1999). Both countries joined the EU in 1973, but by the first half of the 1980s other national parliaments had started to adopt some elements of their scrutiny systems or at least acquaint themselves with the stringent Danish and British procedures for dealing with EU affairs. Second, the adoption of the Single European Act (SEA) played a crucial role in increasing national parliaments' interest in EU affairs. The entry into force of the SEA meant a greater workload for national parliaments due to the transposition of internal market directives (Raunio 1999, p.184), forcing them to become more aware of the challenges posed by European integration. Judge (1995, p.89) argues that the significance of the SEA for national parliaments was linked to ratification requirements, which were used by some parliaments as a bargaining tool to increase information exchange with their governments. As a result, parliaments became increasingly aware of the EU's importance and started to amend their rules of procedure, creating European Affairs Committees (in particular in Belgium, Luxembourg, Portugal and Spain) that acted as hubs of expertise and coordination. Ultimately, national parliaments paid greater attention to EU issues as the area

\footnotetext{
${ }^{74}$ The document refers to decision-making in the Council
} 
touched by EU legislation expanded and the EU's decision-making powers and budget grew (Laprat 1995).

Moreover, during the course of 1980s politicians in both Brussels and the national capitals began to realize that enhancing the power of supranational institutions did not guarantee the legitimacy of the EU. Hence, not only did the competences of the European Parliament have to be increased, as was argued for example by the so-called Toussaint report (European Parliament 1988), but also the involvement of national parliaments in the EU political process. One of the arenas in which to address this issue was a Conference of Parliaments of the European Community (Assizes), proposed in late 1989 by President Mitterrand to the European Parliament (Westlake 1995, p.61), which agreed to the proposal hoping to obtain national parliaments' support for 'deepening' EU integration. The conference took place in November 1990, bringing together members of national parliaments and the European Parliament. In fact, the Assizes were convened on the eve of the Mastricht intergovernmental conference (IGC) and aimed to identify common points of interest between MPs and MEPs, which could later be considered during the IGC. In addition, the Assizes revealed a large number of tensions between MPs and MEPs, which ranged from sitting arrangements and convocation procedures to the agenda of the meeting. As a result, some national delegations were highly critical of the meeting, especially given the fact that the final declaration mostly repeated MEP's praise for developing the EU on a federal basis, contrary to the views of many MPs (Westlake 1995, p.61-62; Bengston 2006, p.164).

Despite the fact that the Assizes did not prepare much detailed practical guidance for the Maastricht IGC or the involvement of national parliaments in EU-level policymaking, in the end some of the ideas of the Conference were included in the final text of the Maastricht Treaty, paving the way for a recognition of national parliaments' competences in EU primary law.

\subsection{National parliaments and EU integration in the aftermath of the Maastricht Treaty}

The Maastricht Treaty explicitly recognized the role of national parliaments in EU integration for the first time. Declaration 13 states that "it is important to encourage greater involvement of national parliaments in the activities of the European Union" and stresses that "member states will ensure that national parliaments receive Commission proposals for legislation in good time for information and possible examination". This represented a major breakthrough in implicitly recognizing the right of national parliaments to monitor both EU legislation and national policies at the EU level. The need for enhanced contacts between the European Parliament and national parliaments was also mentioned, a topic that was further addressed in Declaration 14, which dealt with the recommendations of the Assizes. The key idea was to develop the Assizes as a parliamentary forum for discussing EU issues of relevance to the European Parliament and 
national parliaments, with reports from the heads of the European Council and the European Commission providing the necessary input. This format for cooperation, however, has not been used since. The Declarations attached to the Maastricht Treaty constituted an important step forward in recognizing the rights of national parliaments in the EU policymaking process, but their status was not legally binding. This created an impediment to advancing parliamentary involvement in EU affairs as it did not place any obligations on national governments to inform their respective parliaments on EU topics or define the format of national parliaments' cooperation with EU bodies. Nonetheless, some parliaments, for example the French, German and Portuguese, have used the Maastricht Treaty as a pretext for lobbying for constitutional amendments that give them better access to EU-related information (ECPRD 2003, p.16). In the case of the German Parliament, its powers were arguably enhanced not only by the changes in EU primary law, but also by concomitant rulings of the German Constitutional Court which interpreted the new legal order in favour of the Bundestag and the Bundesrat. The 'Maastricht Decision' of the German Constitutional Court stipulated that the competencies and rights of the German parliament must remain 'substantial' in character, so that it can still hold EU politics accountable. As a result, the Bundestag and the Bundesrat did not just get yet another formal opportunity to participate in EU affairs but were legally obliged to be actively involved in discussions over European Union issues (Sprungk in O'Brennan and Raunio 2007).

The problem of the ambiguous legal status of parliamentary involvement in EU affairs was resolved with the entry into force of the Amsterdam Treaty, as the protocol on the role of the national parliaments attached to the Treaty had a legally binding status. It recognized the 'collective role' of national parliaments in the EU political system. National governments were encouraged to transmit draft legislative proposals and consultation documents, such as the Green Papers and White Papers of the European Commission, to national parliaments ${ }^{75}$. It was further recommended that a six-week period should elapse between the issuance of a legislative proposal and the date when it is put on the agenda of the Council of Ministers. This was meant to determine the time frame for consultations between domestic executive and legislative powers on the national position on a given EU proposal.

The Amsterdam Treaty also officially 'recognized' the Conference of Community and European Affairs Committees (COSAC). The body was first convened in 1989 and bi-annual meetings have been held ever since, dedicated to exchanging information on matters of common parliamentary concern. It is made up of representatives of the European Affairs Committees (EACs) of national parliaments and a delegation from the European Parliament. According to the provisions of the Amsterdam Treaty, COSAC became the nodal point for inter-parliamentary cooperation. It acquired the right to

\footnotetext{
${ }^{75}$ Nonetheless, documents pertaining to the CFSP, enhanced cooperation and integration of the Schengen acquis into the framework of the EU, and those prepared by the European Council were excluded from this process.
} 
address EU institutions on EU legislative activities, effectively encouraging interparliamentary cooperation and networking. The resolutions passed by COSAC, however, are of a non-binding character.

Maurer (in Barrett 2008, p.52) claims that the success of the Amsterdam Treaty in enhancing the role of national parliaments was somewhat limited, as it did not rectify the lack of parliamentary control over EU foreign policy or implementation of the Schengen acquis. Even so, the entry into force of the Amsterdam Treaty triggered important procedural changes in several national parliaments. For example, the French Parliament obtained greater information rights through the amendment of the article 884 of the French Constitution as a result of ratifying the Treaty ${ }^{76}$.

The issue of national parliaments re-emerged in the "Laeken Declaration" by the EU Heads of State and Government (European Council 2001) attached to the Treaty of Nice, and was taken on board by the Convention on the Future of Europe, where a working group on national parliaments was organized (Working Group IV). Roughly at the same time, the European Commission began explicitly to mention cooperation with national parliaments as a crucial element of the EU institutional architecture (European Commission 2002). Several ideas about enhancing the role of national parliaments were discussed: extending national legislatures' access to information; creating a Charter for National Parliaments ${ }^{77}$; developing a European Senate or a Permanent Conference of Parliaments/Congress, proposed by the former French prime-minister Lionel Jospin; and increasing the functions of COSAC ${ }^{78}$.

Most of the proposals found their way into the Treaty establishing a Constitution for Europe. For example, the chairman of the convention working group on national parliaments suggested making the Commission and not governments responsible for forwarding legislative proposals to national parliaments. This idea was endorsed in the Constitutional treaty. The document also granted national parliaments access to information and monitoring in the sphere of justice, liberty and security. Most importantly, parliaments would be able to directly participate in the application of the subsidiarity principle through the Early Warning System (EWS). Within six weeks of a proposal's transmission, a parliament could decide whether it complied with the principle of subsidiarity. National legislatures were allocated votes, ${ }^{79}$ and if one-third (or a quarter if a draft legislative act concerns judicial cooperation on police and criminal matters) of them found a breach of the subsidiarity principle, the Commission would have to re-

\footnotetext{
${ }^{76}$ For more information see Blanc (2004). Les parlements européen et français face à la function legislative communautaire: aspects du deficit démocratique. Paris: L'Harmattan.

77 This idea was proposed by the British House of Commons and implied a set of binding rules for national parliaments in their relations with the European Union institutions

${ }^{78}$ For an overview of the ideas on inter-parliamentary cooperation proposed during the Convention see Neuhold (2003) and Sleath (2007). For the idea of creating a European Senate with a separate chamber for national parliaments see van der Schyff and Leenkneger (2007)

${ }^{79}$ Each national legislature receives two votes, which are divided between the two chambers in case of a bicameral parliament
} 
examine the proposal and consequently withdraw, amend or justify it (the 'yellow card' procedure). If more than half the national parliaments detected a subsidiarity breach, an 'orange card' procedure would be activated. According to this procedure, the European Commission would then either have to amend or withdraw the proposal. If it decided not to do so, the Council of Ministers and the European Parliament could revoke the document, on condition that a majority of MEPs and 55 per cent of the Council members support such a decision.

After the French and the Dutch referendums effectively halted the constitution's ratification process, a debate began about which of its provisions should be taken on board without actually ratifying it (Cartabia 2007). The European Commission took the lead in the debate and launched the so-called Barosso Initiative (European Commission 2006, pp.8-9), which was meant to increase information exchange between the European Commission and national MPs, the former commencing the practice of providing national parliaments with all legislative and non-legislative documents. Initially, not all parliaments seemed willing to take full advantage of this opportunity. The European Commission's annual reports show that although the amount of information exchange has grown, the list of active parliaments stayed almost unchanged for a number of years (European Commission 2008, 2009, 2010). Nonetheless, the Barosso Initiative was able to intensify the political dialogue between national parliaments and the European Commission, and by 2012-2013 all the national legislative assemblies of the EU member states had become involved (European Commission 2011).

Although the 'Barroso dialogue' is an important instrument for information and opinion exchange between national parliaments and the European Commission, it was the Lisbon Treaty that provided national parliaments with key instruments for participating in EU policymaking.

\subsection{The provisions of the Lisbon Treaty on national parliaments}

The Lisbon Treaty by and large repeated those provisions of the Constitutional treaty which address the different competences of national parliaments: ${ }^{80}$

- National parliaments had their information rights expanded, as they acquired direct access to European Commission consultation documents and draft legislative acts including initiatives from groups of member states and the European Parliament, and agendas of Council meetings;

- National parliaments can affect the division of competences between the domestic and EU levels either through the 'Early Warning Mechanism' (EWS) or by appealing to the Court of Justice of the European Union (CJEU). The EWS provides national parliaments with a timeframe of eight weeks to decide on the compliance of an EU legislative proposals with the subsidiarity principle. National parliaments

${ }^{80}$ TEU, Article 12, Article 48; Protocol (№1) on the role of national parliaments in the European Union; Protocol (№2) on the application of the principles of subsidiarity and proportionality 
were also given the right to bring cases on purported subsidiarity infringements before the CJEU, albeit through their respective national governments. Moreover, the right to block the use of a 'passerelle clause' (TEU, article 48), through which the European Council can change its decision-making rules in a policy area from unanimity to QMV, gives national parliaments greater political leverage ${ }^{81}$;

- The role of inter-parliamentary cooperation was enhanced. COSAC still cannot issue binding decisions, but the Lisbon Treaty is explicit on its role in spreading 'best practices' and organizing inter-parliamentary conferences on a number of salient topics such as the Common Foreign and Security Policy ${ }^{82}$;

- Policy implementation in a number of areas has come under more direct control of the national parliaments, which have acquired the right to evaluate policy implementation in the area of freedom, security and justice and to monitor the activities of Europol and Eurojust.

The Lisbon Treaty thus consolidates and codifies a number of practices of national parliaments within the EU political system. Firstly, it consolidates the long-term trend towards acquiring better access to information, which evolved since the entry into force of the Maastricht Treaty. Secondly, the idea to involve national parliaments in subsidiarity checks has been on the EU's agenda since the Convention on the Future of Europe started its deliberations in 2002, yet it is the Lisbon Treaty that formally acknowledges this right of national parliaments. In addition, the Lisbon Treaty provides for a major overhaul of national parliamentary scrutiny of EU affairs.

First, the Lisbon Treaty allows greater involvement in and influence over the legislative process of the European Union for national parliaments. Cooperation between national parliaments and the EU institutions goes beyond the mere exchange of opinions to allow control over the division of competences between the EU and member states and over the decision-making principles of EU policymaking, at least indirectly enabling national parliaments to influence the content of EU proposals.

Second, the provisions of the Lisbon Treaty could trigger the spread of 'best practices' in parliamentary scrutiny and make parliaments more autonomous of domestic governments, exactly as the Single European Act did in 1980s. National parliaments address not only EU institutions but also play a role in domestic executive-legislative relations. Potentially, parliaments that play a minor role in national political systems could use the Lisbon Treaty to enhance their status in both the domestic and the EU arenas. Despite the fact that EU integration is alleged to have increased the powers of domestic executives at the expense of national parliaments, the Lisbon Treaty could

\footnotetext{
${ }^{81}$ National parliaments are to be notified by the European Council about a decision to use the 'passerelle clause'. Any parliament which has objections to it must make its opinion known within six months of the initial notification. A negative opinion of at least one parliament places a veto on the application of the 'passerelle clause'. If no parliament raises objections, the 'passerelle clause' is applied. For additional information see the $9^{\text {th }}$ COSAC bi-annual report (May 2008).

${ }^{82}$ Although this topic is not mentioned in the text of the Lisbon Treaty, inter-parliamentary conferences have started to address the issue of economic governance.
} 
make the latter much more independent of their respective national governments in the area of EU policy, for example, through direct access to EU documentation or by adopting effective institutional practices such as regular cooperation between EACs and sectoral committees.

Third, the increased visibility of inter-parliamentary cooperation may have unintended consequences, most notably increased coordination between representatives of national parliaments in Brussels, MEPs and MPs. This could contribute to the development of a multi-level parliamentary system within the EU (see Abels and Eppler 2011) through new patterns of socialization and policy coordination among parliamentarians from the domestic and EU arenas.

Despite its potential to enhance the power of parliamentary chambers, the Lisbon Treaty does not prescribe a specific model of conducting scrutiny of EU affairs. National parliaments are by and large free to interpret the Treaty provisions according to their own interests. Reform of parliamentary activities in the aftermath of the Lisbon Treaty will depend on specific parliamentary traditions and the current political situation, among other factors. Differences between models of parliamentary scrutiny are likely to persist. Moreover, various models of scrutiny are likely to shape parliamentary debates about EU proposals in a variety of ways. 


\section{CHAPTER 4: National and EU policies in the domains of pension provision and low-skilled labour migration}

This chapter examines the competences of the European Union and EU member states in the domains of pension provision and labour migration policy, providing the context for the study of the debates on the Green Paper on pensions as well as the Proposal for a directive on seasonal labour migrants in the parliaments of Sweden, the Czech Republic and Romania. Parliamentary debates on these EU policy proposals could prove contentious in the sense that they directly correspond with or contradict the preferences of various national political parties and key stakeholders in the electorally salient policy fields of labour migration and pensions. The policy solutions suggested in the Green Paper on pensions and the Proposal for a directive on seasonal labour migrants can feed into domestic debates on pensions and labour migration policy reform in Sweden, the Czech Republic and Romania. This chapter shows how Swedish, Czech and Romanian political parties could use the abovementioned EU initiatives in the parliamentary arena to address the status quo in domestic pension and labour migration regimes to bring them closer to their own preferences.

\subsection{The context of EU involvement in pensions policy}

The EU can influence national pensions policies, but the competences of the EU in the sphere of social welfare are limited. Despite the establishment of the Single Market and European Monetary Union (EMU) as well as the adoption of Broad Economic Policy Guidelines (BEPG), the EU plays only an indirect role in national pension reform (Zaidi et al. 2006), which can generally be narrowed down to facilitating member states' cooperation in response to common problems such as an ageing population. In general, the European Commission has not presented any specific template for pension reform, although the pensions systems of EU member states face similar challenges (Zaidi et al. 2006). Its policy recommendations are largely in line with the 'new pension orthodoxy', which stresses the need to replace current 'pay-as-you-go' (PAYG) public pension systems $^{83}$ with so-called 'multi-pillar systems'. In general, Pochet $(2003$, p.44) argues that in such systems, the 'first pillar' is based on compulsory public pension schemes, financed according to the traditional 'pay-as-you-go' method. The 'second pillar' in-

\footnotetext{
${ }^{83}$ In 'pay-as-you-go' systems, the contributions of current workers finance the retirement benefits of current pensioners.
} 
cludes supplementary pension schemes set-up for employees (occupational pension schemes), although their specific design can vary. Some typologies of pension systems also include mandatory private pension schemes in the 'second pillar' (Holzman and Hinz 2005; Bovenberg and van Ewijk 2011, p.18). The 'third pillar' is comprised of voluntary private pension saving schemes. In principle, while developing multi-pillar schemes, national actors can refer to the EU either in order to shift the blame, stressing the role of the EU in promoting unpopular reform, or to use the European Union's authority as leverage to overcome resistance to domestic social policy reforms.

Member states have been very reluctant to delegate social policy competences to the EU level. For example, several provisions of the Lisbon Treaty, such as Protocol 26 on services of general interests and article 48, TFEU, stipulate that the activities of the EU should not affect the ability of member states to provide general services of noneconomic interest ${ }^{84}$. Member states are also empowered to postpone adoption of any legislative proposal on the social entitlements of migrants if it is deemed to negatively affect national social security systems.

Regardless of such restrictions, the EU has slowly increased its role in this policy domain through labour market regulation (health and safety at work, gender equality in pay, etc.) and financial market regulation (removing obstacles to investment in supplementary pension funds). In fact, the introduction of 'four freedoms' has pushed enhanced coordination of social security policies within the EU. For example, in the view of the Commission, the 'third pillar' of national pension systems - voluntary contributions to private pension funds - should be bound by Single Market competition rules as such pension funds are not solely engaged in the provision of public goods but deal with profit-making as well (Ferrera 2009). Within the European Commission, discussions on pension system reform were historically centred around the DG for internal market and not DG for social affairs, which to a large extent supports the idea that EU policies are largely in line with the 'new pension orthodoxy' (Jensen and Pochet 2002, p.16).

The Court of Justice of the European Union (CJEU) also affects national pension systems ${ }^{85}$, primarily through its rulings on competition policy. Continual reference to the notion of 'equal treatment' (based on the article 199 of the Treaty of Rome) has allowed the CJEU to have an impact on private and, to a lesser extent, public pension schemes (Leibfried in Wallace et al. 2005). Several rulings of the Court of Justice of the European Union from the 1970s (Defrenne I, II, III cases) paved the way for a number of EU proposals dealing with gender equality in social security and pension benefit provision, for example the Equal Pay Directive, the Equal Treatment of Work Directive and the Equal Treatment in Social Security Directive. The Portability of pension rights ${ }^{86}$

\footnotetext{
${ }^{84}$ According to SEC (2008) 2179, these include health care, several types of social security schemes and personal social services such as social assistance, housing and childcare.

${ }^{85}$ On the interplay between the notions of 'economic competition' and 'social security' in the CJEU rulings see Bosco (2000) Vers une remise en cause des systemes nationaux de protection sociale? Observations sur la jurisprudence récente de la Cour de Justice, in Problématiques européennes, 7.

${ }^{86}$ The capacity to preserve the accrued value of pension rights when switching jobs and pension schemes.
} 
for both EU citizens and third-country nationals also became the topic of several CJEU rulings, for example in the Piscitello case of 1983 and the Giletti case of 1986 (Natali 2008, p.187). The European Commission has been very willing to use such CJEU rulings to argue for better coordination of national pension policies.

At the same time, the financial and the economic crises could be conducive to increasing the role of the European Commission in pension policy under the guise of promoting sound financial management and anti-crisis measures, for example, within the framework of the 'European Semester ${ }^{\text {, }}$. In fact, as a respondent from the European Social Observatory (B8) argued, the EU has made detailed proposals on the transformation of pension systems in Spain, Greece and Portugal. In fact, the European Commission started to develop legal instruments for the EU's involvement in the pensions sector much earlier, one of the first attempts being the proposal by commissioner Sir Leon Brittan to develop a Single Market for pensions. The first documents stipulating the EU's role in regulating this national policy sector started to appear in the second half of 1990s.

\subsection{EU legislation in the pensions sector}

The Green Paper on supplementary pensions, published in 1997, highlighted increased EU interest in the development of national pension schemes ${ }^{88}$. The document explicitly stated that each member state was free to choose the design of its pension system, but argued for pension fund investment to be considered an integral part of an EU-wide financial market. The Green Paper was framed in such a way as to identify potential complications in the functioning of the prospective Single Market for pensions. The European Commission attempted to act as an agenda-setter in this policy domain, although it did not find support from any of the member states.

The next major step in developing EU regulation in the pension sector was Council Directive 98/49/EC ${ }^{89}$, which addressed the rights of participants in supplementary pension schemes who moved between member states. This was to be done by making cross-border pension payments free of charge, and enabling 'posted' workers to continue to make contributions to their home country supplementary pension schemes. The directive did not address the portability of pension rights, that is, the capacity to preserve the accrued value of pension rights when switching jobs. The European Commission later came up with a proposal to address portability of pension rights ${ }^{90}$, but it found no support among member states as it was perceived to damage the established balance of interests between various national social partners (Mabbett 2009).

\footnotetext{
${ }^{87}$ The European Semester is the annual cycle of macro-economic coordination among the EU member states.

${ }^{88}$ COM (1997) 0283 final.

${ }^{89}$ OJ L 209. 25.07.1998, p.46-49.

${ }^{90}$ COM (2005) 507 final.
} 
A major step forward in developing EU pension regulation was the introduction of the Open Method of Coordination (OMC), which helped define broad objectives of cooperation between the EU and its member states on pension policy during the Stockholm and Göteborg European Council summits in 2001 ${ }^{91}$. The Open Method of Coordination highlighted the existence of divergent approaches to pension policy within the EU. For example, according to an expert from the European Social Observatory (B8), for the Social Protection Committee $(\mathrm{SPC})^{92}$ the introduction of the Open Method of Coordination into pension policy was a way to rebalance the market bias of the EU as well as to start discussing the adequacy of pensions. For the Economic Policy Committee $(\mathrm{EPC})^{93}$, however, it was a way to influence social affairs ministers, and to introduce a more economics-orientated discourse (de la Porte and Pochet 2001). Despite the large number of inter-institutional debates, it can be said that the OMC had only a limited impact on national pension policies (Eckhardt 2005; Lodge 2007; Citi and Rodes 2007; Schrader 2010) $)^{94}$.

The next major step in developing EU policy in the pension domain was the adoption of the Directive for Institutions on Occupational Retirement Provisions (IORP) in 2003. This directive enabled pension funds to benefit from the Single Market principles of free movement of capital and freedom to provide services. The document allowed pension funds to manage occupational pension schemes for companies established in another member state, although conditions of operation are largely determined by the host country. The directive is based on the principle of mutual recognition, so it cannot be used as leverage for greater harmonization. Effective application of the directive was hampered by a number of legal issues, not least the failure to clearly delineate the relationship between a host country and foreign pension funds, as well as the inability to come up with a solution for a cross-border taxation regime for pension funds (van Meerten and Starink 2011; Guardiancich 2011). Some of these issues were later addressed in the Green Paper on pensions.

\subsection{Overview of the Green Paper towards adequate, sustainable and safe European pension systems}

The Green Paper towards adequate, sustainable and safe European pension systems (COM 2010365 final) was presented by the European Commission in early July 2010. Three DGs were involved in the preparation of the Green Paper (EMPL, ECFIN, MARKT), each of which had a different agenda. According to respondents from the European Commission (B9, B10), the main aim for DG EMPL was to provide an as-

\footnotetext{
${ }^{91}$ On the process of defining common policy objectives within pension OMC see, for example, Vanhercke (2006), Natali (2009)

${ }^{92}$ An advisory policy committee which monitors social conditions within the EU and promotes coordination of regulatory mechanisms

${ }^{93}$ An advisory body that contributes to the work of the Ecofin Council as well as the European Commission

${ }^{94}$ For a more positive evaluation of the pension OMC see Vanhercke (2009)
} 
sessment of ongoing pension reforms and provide advice on the optimal relation between public and private pension funds. The concern of DG MARKT was with establishing a common playing field and facilitating cross-border pension fund activity. DG ECFIN was occupied with developing a mechanism for pension fund financial stability. The economic crisis meant that the Green Paper lost its importance for DG ECFIN, as it shifted its focus to economic policy coordination proper.

The Green Paper does not propose an EU-encompassing clear-cut template for pension system reform. It explicitly states that member states are free to determine the detail of their social security systems. Nonetheless, it argues that member states' actions in the pension domain should be more coordinated, as failure to do so will inhibit labour mobility within the EU as well the application of the 'four freedoms', which will have a negative effect not only on the Internal Market or the Stability and Growth Pact but also on the EU's ability to meet the broader socio-economic goals of the Europe 2020 strategy. The European Commission stressed that pension funds are an integral part of the financial markets, implying that the rules developed at the EU level for regulating financial services should be applicable to private pension funds as they are geared to creating economic benefits in addition to providing basic social support. In order to diminish irregularities in the application of the 'four freedoms' in the pension sector, the European Commission proposed a number of policy solutions in the Green Paper.

Among others, the document suggests a revision of the Directive for Institutions on Occupational Retirement Provisions (IORP) in order to address the issue of tax discrimination in cross-border pension funds. In order to enhance social security conditions for the mobile EU workforce, the Green Paper proposes the establishment of an EU-level tracking system of pension rights what would allow employees to obtain detailed information about their social contributions and the benefits that they have in different EU member states. Another idea mentioned in the Green Paper is the creation of a separate EU-wide private pension regime (as the so-called Monti report suggested) ${ }^{95}$ in addition to national pension schemes, although few specific details were given. Moreover, the European Commission proposed to spread the application of the Solvency II directive to the pensions sector. This would mean that the stringent schemes guaranteeing the solvency of insurance companies would apply to pension funds in order to secure pension benefits against potential financial risks.

The Green Paper on pensions was considered in the European Parliament's Employment and Social affairs committee (EMPL), with a report drawn up by Ria OomenRuijten (European People's Party, EPP) ${ }^{96}$ which by and large endorsed the Green Paper's provisions. Although the report stressed that member states are ultimately responsible for their respective welfare and pension policy, it deplored the fact that the EU

\footnotetext{
95 A new strategy for the single market at the service of Europe's economy and society. Report to the President of the European Commission José Manuel Barroso by Mario Monti, 9 May 2010.

${ }^{96}$ European Parliament (2010) Draft report on the Green Paper entitled "Towards adequate, sustainable and safe European pension systems" (2010/2239 (ENI)). Committee on Employment and Social Affairs. Raporteur: Ria Oomen-Ruijten.
} 
lacks mechanisms for transparent supervision in the sector. The document does not foresee the EU being able to determine the adequate level of pensions, but assumes that member states can set common minimum criteria for this. The report by Oomen-Ruijten served as the basis for a European Parliament resolution, adopted on 16 February 2011. The resolution largely repeats the content of the report ${ }^{97}$, although any reference to linking retirement age to life expectancy had to be scrapped due to resistance from the Group of Progressive Alliance of Socialists and Democrats (S\&D) and the Group of the European United Left-Nordic Green Left (GUE/NGL), as a staff member of the European Parliament explained (B19) ${ }^{98}$.

National parliaments were not involved in the preparatory work on the Green Paper on pensions, as a number of respondents noted (B9, B10, B11, B36). The only exception was a short information session for the representatives of national parliaments to the European Parliament, organized at the end of May 2010 by a staff member of DG EMPL. There was no collective request from national parliaments to organize an information session, just individual ones which were later addressed in one day during a traditional information meeting on EU legislation. As a staff member of DG EMPL (B9) argued, representatives of national parliaments were mostly concerned about whether there was a direct link between the provisions in the Green Paper and plans for enhanced economic coordination among member states under the auspices of the European Commission. Several representatives of national parliaments also raised concerns about potential violation of the subsidiarity principle by the provisions in the Green Paper. There were no attempts or requests from national parliaments to follow up on the Green Paper. By February 2012, the European Commission had developed another policy document on the basis of the Green Paper, the White Paper "Agenda for adequate, safe and sustainable pensions".

\subsection{Overview of the White Paper "Agenda for adequate, safe and sustainable pensions"}

The White Paper (COM 2012 55/2) was published in February 2012 after a delay of about five months from the originally intended date in the third quarter of 2011. Despite reference to the fact that member states should define the parameters of their pension systems, the White Paper stressed that "pensions are increasingly becoming a matter of common concern in the EU" due to the fact that the economies of the EU member states are becoming increasingly integrated and the performance of domestic pension funds has economic implications beyond national boundaries.

The White Paper proposed a number of policy solutions, such as later retirement and increased saving for pensions, a greater link between statutory retirement (the age

\footnotetext{
${ }^{97}$ P7_TA-PROV (2011)0058. 16 February 2011.

${ }^{98}$ On the discussion of the Green Paper in the European Parliament see EurActiv: Brussels wants pensions pegged to life expectancy, 21 February 2011
} 
when an individual is legally obliged to take a pension) and life expectancy, and access to life-long learning. The need to develop pension rights tracking services as well as to review the Directive for Institutions on Occupational retirement provisions and several other EU legal documents related to the pension policy sector was also acknowledged. The European Commission was explicit about the fact that it has "no powers to legislate on the design of pension systems as such", but stated that it can legislate on matters affecting the functioning of the Internal Market and issues dealing with discrimination in workers' rights.

The draft report on the White Paper was discussed and adopted by the Employment and Social Affairs Committee (EMPL) of the European Parliament in March 2013. The document was also prepared by Ria Oomen-Ruiten (European People's Party / EPP), who was in charge of making a report on the Green Paper on pensions. The report on the White Paper on pensions was subject to a plenary debate in May 2013, where it was adopted without major changes ${ }^{99}$. The report agrees with the policy solution proposed in the White Paper, albeit stressing the fact that public pensions should guarantee decent living standards, especially in the countries worst hit by the economic crisis. At the same time, the document is critical of the Commission's proposal to apply stringent solvency rules normally used in the insurance sector to pension funds. A staff member of the European Parliament confirmed (B19b) that none of the national parliaments contacted the rapporteur to obtain extra information, the only exception being the Dutch Parliament as the report was discussed by Christian-Democratic Appeal (CDA) - the party to which the rapporteur belongs.

\subsection{Pension policy in Sweden}

The need to reform the Swedish pension system became apparent in late 1980s as its sustainability was threatened by slackening economic growth and increased early exit from the workforce. As a result, a Pension Committee was established to bring together representatives of political parties and the relevant stakeholders. Several broad points of consensus about pension system reform emerged. First, pension benefits should be closely linked to contributions. Second, the amount of benefits should grow according to the wage received by an individual.

These principles determined the work of the Pension Group, which was established after the 1991 general election (Palmer 2002). The defeat of the Social Democrats triggered a paradigm shift in the attitude to welfare systems (Arter 1999), making a greater role for the market in the pension sector more legitimate and acceptable. In other words, the defeat of left-wing parties made possible the transition of the Swedish pension system towards a defined contribution scheme (DC) ${ }^{100}$.

\footnotetext{
${ }^{99}$ P7_TA(2013)0204, 21 May 2013

${ }^{100}$ A defined contribution pension scheme means that a person's pension is not paid out of the contributions of the current workforce as in pay-as-you-go schemes, but is based on a person's own contributions throughout
} 
The new electoral situation also contributed to the fact that Swedish pension reform was accomplished within a broad inter-party consensus (Andersen and Immergut 2007), as no party had sufficient electoral support to singlehandedly impose its opinion. Initially launched by a centre-right minority government with the support of the Social Democrats, in its latter stages the pension reform was carried out by a Social Democratled government backed by centre-right parties. Although all the political parties initially had divergent preferences, the consensus style of policymaking was greatly assisted by the fact that their representatives in the Pension Group were obliged to consult each other first and only then report to their respective parties (Könberg, Palmer and Sundén 2006; Anderson and Meyer 2003). Various stakeholders, NGOs and trade unions were not made members of the Pension group, although they were informed about the progress of negotiations. At the same time, a somewhat implicit decision was made to keep pensions policy out of electoral competition. Establishing an inter-party consensus provided a type of lock-in, which enabled the content of Swedish pension reform to survive intact despite electoral change.

In 1994, the final report on pension reform (SOU 1994:20) was presented to the public. It was accepted by the government in June the same year. A special committee, drawn almost entirely from members of the Pension Group, was set up in order to transpose the reform guidelines into draft legislation. First legislative proposals were ready by June 1995, but the work was almost undone by a threat by the Social Democrats to pull out of the agreement due to resistance by rank-and-file members. The conflict was triggered by the fact that the content of the pension reform had been approved by the leaders of the Social Democrats ahead of the party congress, leaving little room for any internal party discussion. The leadership of the Social Democrats was able to see off the opposition by stressing the risk of upsetting the multi-party agreement (Kangas, Lundberg and Ploug 2006, p.22-23). These delays contributed to the fact that legislation to enact the pension reform was approved only in 1998.

The major innovation of the 1998 reform was the introduction of the so-called notional defined contribution (NDC) scheme. In the notional defined contribution scheme, the pension benefits of the current generation of retirees are paid from the pension contributions of the active working population. The level of pension, however, depends on the previous salary of the individual. The technical innovation of the notional defined contribution scheme lies in the fact that on retirement, all the contributions to the public pension fund that an individual has made during his/her working life are converted into an individual savings account. In fact, these accounts exist only on paper - hence the term 'notional' contribution scheme - as the money has already been used to pay the pension benefits of the previous generation of pensioners. Nonetheless, these notional accounts are converted into annuities, which determine the level of pen-

his/her working life and the investment strategy of a specific pension fund that manages these contributions. It should be stressed that within a defined contribution scheme, only the level of contributions is predetermined while the level of benefits that a person receives in old age is harder to foresee. 
sion that an individual gets. Moreover, these notional accounts are automatically indexed on an annual basis, depending on the changes in the average income of Swedish wage earners between 16 and 64 as well as the rate of growth of Swedish gross domestic product (GDP).

Sweden has a strong budgetary position and its pension reform has been highly praised (EPC-SPC 2010, p.45), but the notional defined contribution system could face several challenges. For example, in 2008 the government intervened in the pension indexation, which is normally carried out automatically, in order to prevent a rapid decline in pension benefits, as slow economic growth meant 'negative' pension indexation. According to both experts (B8) and stakeholders (S15), such a decision must have been the result of a political bargain within the Pension Group. However, this raises doubts about the ability to sustain automaticity in the notional defined contribution system in the long run.

Despite the fact that the Swedish pension system largely corresponds with the proposals made in the Green/White Paper, a representative of a Swedish stakeholder in the pensions sector (S15) argues that both EU documents could have an impact on supplementary pension schemes in Sweden. Sweden relies heavily on occupational pension schemes, so an envisaged revision of the Directive for Institutions on Occupational Retirement Provisions would affect the work of Swedish pension funds. According to representatives of the Swedish confederation of enterprise (S21), the conditions for conducting business abroad would also be affected if the issue of cross-border pension fund activity were addressed by the EU - exactly as both the Green and the White papers suggest.

Moreover, the proposals made in both papers could add to the ongoing debate among Swedish political parties on pension reform. A journalist (S19) specializing in pension issues from the Swedish national newspaper, Svenska Dageblat, argued that although representatives of the political parties in the Pension Group always try to reach a compromise, the inter-party consensus on pension policy is likely to become more fragile as the general public becomes more concerned about decreasing pension benefits. Moreover, according to a former staff member of the Riksdag European Affairs Committee (S38), the Green Party recently made attempts to join the Pension Group, although so far it has been unsuccessful. This shows that parties that did not participate in the setting up of the notional defined contribution system increasingly see political benefits from getting involved in the ongoing debate. In addition, the representatives of the Social Democrats in the Pension Group have started to voice criticism of some elements of the Swedish pension regime. So far, in the opinion of a journalist (S30) specializing in pension policy from Dagens Nyheter, inter-party discussions on pension reform do not touch on the core of the notional defined contribution system but address more technical issues such as taxes for pensioners or decreasing the number of funds that manage voluntary private pension savings. Nonetheless, in the opinion of some trade union representatives (S14) and journalists (S19), changes in the economic situa- 
tion may force Swedish parties to break with the tradition of depoliticized pension reform.

The Swedish Government has also become more concerned with this policy sector. According to representatives of the Swedish confederation of enterprise (S21), a vivid example was the decision of the government to commission a report on the development of the national pension system, which was published in mid-2012. Another symbolic gesture that reflects the saliency of the pensions topic in Swedish politics is the proposal by the Swedish Prime Minister, Fredrik Reinfeldt, to increase the retirement age to 75 for those who are still able and willing to work, which could prove very divisive. In principle, this suggestion fits the Green/White papers' emphasis on longer working lives and linking retirement age to longevity, which could help decrease the pension fund deficit. However, the proposal may not pay enough attention to the differences between a statutory retirement age (the age when one is legally obliged to draw pension) and the practice of early retirement in some sectors of the Swedish economy. In general, Swedes retire between 65 and 67, but in the industry sector retirement is very often claimed around 61 or 62 , although this means that the level of pension is reduced. Increasing the retirement age to 75 could mean that those unable to continue to work after 61 or 62 would face dire financial consequences. Hence, according to an expert on Swedish politics from Uppsala University (S20), the suggestion to increase the retirement age would create discrepancies among social groups. The proposal was met with scepticism by representatives of the opposition as, according to a member of the EAC from the Social Democratic Party (S32), linking retirement age to longevity would raise concerns among the voters for the left wing parties. For example, when in 2013 the Prime Minister reiterated his ideas about raising the retirement age to 75 and making it possible to take early retirement only after 63, the Social Democrats were extremely negative about the changes. Such a move would harm the interests of their voters ${ }^{101}$ as they represent the group that is most likely to be disadvantaged. It remains to be seen whether left wing opposition will amount to strong resistance to the government's proposal, as so far neither journalists (S30, S37) nor experts (S16, S17) have observed coordinated action by the Left Party, the Greens or the Social Democrats in the pensions sector. Nonetheless, it is likely that any attempt to increase the retirement age will be very difficult to sell to the public.

\subsection{Pension policy in the Czech Republic}

It is not only the older EU member states that are struggling to develop an "optimal" design of pension systems. The newer EU member states from Central and Eastern Europe face similar challenges. The major difference between the Czech pension system reform and the way such reform was carried out in Sweden is that the former was conducted in an environment of acute inter-party rivalry. This rivalry was already evident in

${ }^{101}$ Sweden considers raising retirement age to 75. EurActiv. 27 February 2013. 
mid-1990s, when the Pension Insurance Act (Act 155/1995) was passed. The document introduced a new pension system design, which combined a compulsory public pension scheme ('first pillar') and a voluntary supplementary pension scheme ('third pillar'). The 'second pillar' of the pension system, either in the form of a mandatory private pension scheme or occupational pensions, has not been introduced in the Czech Republic. Since the 1990s, the issue of introducing the 'second pillar' has been a politically sensitive question and political parties have held divergent views about the desirable proportion of private and public funding in the Czech pension system. The pattern of recurrent partisan contestation around the pension system was set in 1995. For example, the government's draft law on pension reform was approved by parliament despite the fact that support from one of the governing coalition partners, the Christian and Democratic Party-Czechoslovak People's Union (KDU-ČSL), was lacking (Müller 1999). Trade unions, however, objected to the reform and the increase in the retirement age, and gave their support to the Social Democrats (ČSSD) which beat Vaclav Klaus' centre-right government in the 1996 general elections. This set the pattern. The centre-right Czech parties push for a greater role for private funds in the Czech pension system, while the left parties stress the sustainability of the public pension scheme and are ready to allow the presence of private funds in the Czech pension system only to a limited extent.

In technical terms, the Czech pension reforms of 1990s and 2000s revolved around one key element, the role of private pension funds. Allegedly, the government was restrained in promoting the privatization of the pension sector due to the potentially high financial cost of the reform ${ }^{102}$ (Màcha 2002, Cerami 2006). It concentrated instead on technical changes to the public pension scheme or raising the retirement age (ChlonDomińczak and Mora 2006). Unfortunately, this could not prevent the growth of pension budget deficit. The representative of the Czech and Moravian Chamber of Trade Unions (ČMKOS) (C32) considers that occupational pension schemes ('second pillar') were never properly introduced, allegedly due to resistance from private pension funds which tried to limit potential competition (Vavrejnová, Belabed and Wörister 2004) and from non-socialist parties who were afraid of the subsequent rise in the influence of trade unions.

By the early 2000s, the need for another pension reform had become apparent. A journalist specializing in pension issues from the national newspaper Lidove Noviny (C24) argued that these reforms were initially supposed to be developed on the basis of inter-party consensus. Negotiations were launched in 2005 within the framework of the so-called first Bezdek Committee, which involved representatives of political parties and affiliated experts. The task of the committee was to provide an assessment of the

\footnotetext{
${ }^{102}$ Switching from public to private pension funds could result in a temporary increase in the pension budget deficit. Such reforms mean that money has to be saved and invested in order to provide pensions for future generations of retirees, while at the same time funds have to be redistributed to the current population of pensioners through the public pension system. As a result, governments need to borrow money in order to carry out both tasks, which leads to an increase in the pension budget.
} 
political parties' pension reform initiatives, and four proposals were evaluated. The committee almost reached an agreement on the design of the new pension system but, according to an expert from the Charles University (C28), the compromise eventually failed because the Czech communists pulled out of the agreement and the proposal could not obtain enough support in parliament. Another reason, as a staff member of the Czech Permanent Representation argued (B33), could have been that all the negotiations took place at the end of the electoral term, so no party wanted to take the risk of alienating their supporters. This meant that the left parties could not risk agreeing to measures in support of private pension funds.

Despite the failure of the first Bezdek Committee, pressure from international financial institutions and the growing deficit in the public pension budget pushed the government to convene a second Bezdek Committee in 2010, which was asked to come up with an optimal pension system design. In the opinion of an expert on the Czech pension system (C28), the second committee was less representative as it included only one representative of the trade unions and the Social Democrats, with the remaining members from private pension funds and the centre-right parties. This could have created a bias in the committee's assessment.

A new draft design for the Czech pension system was presented in late November 2010, and members of the governing coalition reached an agreement on pension reform in January 2011. According to the reform plan, by 2013 the Czech pension system would be supplemented by a voluntary occupational pension scheme ('second pillar'), targeted specifically at employees in their mid-30s ${ }^{103}$. In 2012, the reform proposal was voted down in the Czech Senate, controlled by the Social Democratic party (ČSSD), which feared that the establishment of the second pillar would effectively privatize the pension system and make their voters worse off, as their economic position would not allow them to make the necessary contributions to such funds. The lower chamber, however, was able to overcome the veto, enabling the centre-right government to continue with the necessary technical preparations. However, in the aftermath of the 2013 elections a left-wing coalition came to power led by the ČSSD. It was announced that the 'second pillar' would be abolished by 2016 and the funds transferred to the existing 'third pillar', heralding yet another change in the course for Czech pensions policy ${ }^{104}$. This shows that the Czech political parties were unable to overcome their ideological differences. According to an expert from the CERGE-EI think tank (C13), while the centre-right parties, such as the Civic Democratic Party (ODS) and the 'Tradition, Responsibility, Prosperity Party' (TOP-09) stressed that the introduction of the 'second

\footnotetext{
${ }^{103}$ It should be stressed that Czech pension reform does not imply the creation of an occupational pension scheme in which employers make contributions to the pension benefits of their workers. Instead, employees themselves can direct up to $5 \%$ of their salaries to the new pension saving scheme.

${ }^{104}$ New Czech government looks set to dismantle second-pillar pension system, 16 December 2013 (http://www.ipe.com/new-czech-government-looks-set-to-dismantle-second-pillar-pension-

system/10000625.article); Czech minister confirms closer of second pillar by 2016, 4 February 2016 (http://www.ipe.com/czech-minister-confirms-closure-of-second-pillar-by-2016/10000921.article)
} 
pillar' would draw pension benefits from different sources and hence make the Czech pension system sustainable, the left-wing parties such as the Social Democrats and the Communist Party of Bohemia and Moravia (KSČM) claimed that the 'second pillar' was a way for citizens that are well off to make less of a contribution to the public pension scheme, which would increase social inequality and endanger the well-being of their electorate. For the time being these ideological differences seem to be irreconcilable, which makes long-term agreements on pension reform increasingly difficult as the risk that the design of the Czech pension system will be renegotiated after every electoral change is very high.

The policy proposals envisaged in the EU Green Paper and White Paper can be seen as an additional trigger for inter-party debate on pension reform. In the opinion of a trade union representative $(\mathrm{C} 32)$, both are very close to the pension reform scenario proposed by the government, but their discussion could help reinvigorate the national debate on pension system reform. An important example is the conflict that took place in 2010 between the European Commission and the Czech Republic concerning implementation of the Directive for Institutions on Occupational Retirement Provisions (IORP). In the absence of full-scale occupational pension schemes, the Czech Republic failed to comprehensively transpose the abovementioned directive which led to a ruling by the Court of Justice of the European Union (Case C-343/08) and financial sanctions against Prague ${ }^{105}$. According to an expert at the Charles University (C28), the ruling was not a prominent topic in the Czech public debate despite the fact that it has important repercussions for the division of competences between the EU and its member states in the domain of pensions policy. Although both the Green and the White papers explicitly state that member states are responsible for the design of their own pension systems, the ruling of the Court of Justice of the European Union can be considered an attempt to prescribe a template for pension system design. In general, the ruling on case C-343/08 provides Czech Eurosceptic parties such as the Civic Democratic Party (ODS) with a good excuse to criticize the EU for double standards and impinging on the sovereign rights of member states.

It is important to note that in the 2010 election campaign, pension issues were on the agenda of all the Czech political parties, directly relating any reforms envisaged in either the Green or the White papers to partisan priorities. In the opinions of both experts (C28) and journalists (C24), further pension cuts introduced in 2012 could help mobilize pensioners, who constitute a 'voter army of 3 million people'. Pension politics therefore remain a divisive issue and the policy prescriptions of the government and the EU correspond with the left-right cleavage of the Czech political system. This political conflict is exacerbated by the fact that the Czech pension system is in the risk zone due to rapidly rising age-related public expenditure, which could make further reforms necessary (EPC-SPC 2010, p.46).

\footnotetext{
${ }^{105}$ Judgment of the Court of 14 January 2010 (http://curia.europa.eu/juris/documents.jsf?num=C-343/08)
} 
Ultimately, the importance of both the Green Paper and the White Paper to the Czech pension system is not derived from direct pressure for a specific 'EU template'. It is linked to the fact that the policy solutions proposed by the EU are closely aligned with the preferences of the centre-right parties and contradict the wishes of left-wing parties and their respective voters, which could reinvigorate the domestic debate on pensions.

\subsection{Pension policy in Romania}

Throughout the 1990s, the Romanian pension system was left virtually unchanged due to the inability of the parliamentary parties to establish an agreement on the broad goals of reform. According to Toma (2004), this led to a situation in which the pension system was fragmented well into the 2000s. The rapid development of the informal economy quickly melted away the contributor base (de Menil and Sheshinski 2002, p.402), making it increasingly difficult for the government to meet its welfare obligations. The number of contributors sank from 8 million in 1990 to 4.5 million in 2004 (Holzman and Guven 2009, p.212). In practice, retirement was used as an instrument to mask rapidly rising unemployment.

As Ormeanu (2010, p.70-71) states, reform of the Romanian pensions sector began as a by-product of negotiations to gain membership of the EU and NATO. Romanian political parties needed to establish domestic consensus in order to prepare the country for accession, which made them more open to accommodating each other's policy preferences - including in the pension policy sector. Attempts to establish an inter-party consensus resulted in the introduction of Law 19/2000, which set out the foundations for contemporary Romanian public pensions. In general, the law turned out to be a compromise between the government, which was attempting to reduce the level of social security benefits provided by the public budget, and parliament, which lobbied to maintain the high level of welfare inherited from the pre-1989 socialist era (de Menil and Sheshinski 2002, p.411). The compromise was weak and the law underwent some 40 amendments throughout the 2000 s.

At the end of 2000, the outgoing centre-right government attempted to establish a mandatory private pension scheme as the 'second pillar' of Romanian pensions policy. The proposal stipulated that although the total amount of pension contributions would stay the same, about one-third of the sum would be allocated to individual accounts which were to be managed by private sector companies. The proposal encountered opposition from trade unions as it did not give any guarantees on the rate of return from the investment, making it difficult to predict the final amount of pension benefits. The governing coalition remained divided on the need to introduce the 'second pillar', but the reform was enacted through an emergency ordinance, effectively a by-law which made parliamentary approval for the reform unnecessary and gave the executive unilateral powers to implement the new measures. After the 2000 general election, the new 
centre-left government of Adrian Nastase (PSD / Social-Democratic party) revoked the bill, putting the reform on hold for almost four years. Eventually, however, the need to coordinate Romania's social protection regime with EU policies on the eve of accession, and growing concerns about the sustainability of the pension system (Armeanu 2010, p.87), led the Romanian Social Democratic party to change its position ${ }^{106}$. At the end of its 2000-2004 term the government finally adopted the mandatory private pension scheme under Law 411/2004.

The 'third pillar', dealing with voluntary private pension schemes, was adopted as Law 204/2006 by a centre-right coalition. The opposition, in the form of the Romanian Social Democratic Party and the Great Romania party (PRM), a left-wing nationalist party, also supported the bill. According to the law, only individuals who are enrolled in the public social security system can contribute to voluntary pension funds, while contributions are limited to 15 per cent of gross wage. Unlike mandatory private pension schemes, voluntary private pension schemes are obliged to provide a minimum return guarantee.

One of the controversial elements in the Romanian pension system is the occupational pension schemes for different categories of workers, such as miners, the military and lawyers. In February 2010, a new bill on a unified system of public pensions was introduced in parliament. It envisaged the elimination of special pensions for various groups of workers, curtailed early retirement and tightened the entitlement criteria for an invalidity pension. Some categories, for example, the staff of magistrates, are not subject to the new regulations, which raised concerns about the integrity of the public pension scheme.

Although the general framework of the Romanian pension system has been established, it is still subject to arbitrary interventions from the government, which raises concerns about the sustainability of the entire structure of the welfare system (EFRP 2009). For example, in 2009 Romania reduced its contributions to mandatory private pension funds to help cover the deficit in the state budget. Moreover, in 2010 the Romanian Government announced a 15 per cent reduction in the size of public pensions in order to reduce the budget deficit. The country's Constitutional Court ruled against it, however, claiming that "pensions are an acquired right that could not be adjusted in an ad hoc fashion" (Orenstein 2011, p.74). Such measures can have a political effect as they can help mobilize voters who feel threatened by a government's actions.

At the same time, according to several experts working for think-tanks (R4, R6), no Romanian political party has clear ideas about the pattern of pension system reform. Pensions are politically salient due to the fact that all parties attempt to mobilize 'floating voters', the majority of whom are pensioners. Romanian political parties know that something has to be done about pensions but, in the opinion of think tank and academic

\footnotetext{
${ }^{106}$ Lambru and Chiritoiu (2002) argue that the accession process has to a large extent set the framework for the reform of social policy in Romania, although their argument seems somewhat exaggerated as their examples relate mainly to non-legislative EU documents.
} 
experts (R14, R15, R20), they avoid making specific recommendations as this could alienate potential voter groups.

The Green Paper and White Paper on pensions could reinvigorate the domestic debate on pension policy reform exactly as Romania's accession to the EU did earlier. Given that according to the joint report of the Economic Policy and Social Protection Committees $^{107}$ (EPC-SPC 2010, p.46), Romania faces a high risk in terms of pension system sustainability, the proposals by the EU could force Romanian political actors to clearly define their preferences on pension policy and develop instruments to achieve these goals. Moreover, both EU papers on pensions raise the issue of the portability of pension rights. This is a sensitive topic for Romania. If the accrued value of pensions cannot be freely moved between EU member states, Romanian workers returning home will put an additional strain on the national welfare system. As is demonstrated below, the policies of the EU in general and the Proposal for a directive on seasonal labour migrants in particular raise fundamental questions about the connection between welfare provision and labour migrant status.

\subsection{The evolution of EU competences in the field of low-skilled labour migration}

Developing common policies and rules in the field of economic migration has proved extremely difficult for the EU. Attempts to address conditions of entry and residence for third-country nationals seeking employment in the EU were made by the European Commission as early as $2001^{108}$, although the proposal was later withdrawn due to resistance from member states (Menz 2010). According to Boswell and Geddes (2011, p.93-94), the involvement of the European Commission in labour migration policies has been ambiguous. Generally, it has attempted to influence labour migration through its competences in managing the Internal Market and the 'four freedoms'. The Commission has only limited competences to regulate labour migration from outside the European Economic Area, which strongly limits its political leverage.

The Green Paper on the EU's approach to managing economic migration ${ }^{109}$ was the first major attempt by the European Commission to harmonize, if not to 'communitarize', migration policies within the EU. In order to limit the potential resistance of member states, the Commission explicitly stated that national governments should retain the right to determine the volume of admission of third-country nationals seeking employment. The Commission envisaged further coordination of national migration

\footnotetext{
${ }^{107}$ Advisory bodies within the EU decision-making structure

${ }^{108}$ Interestingly, the proposal also included some provisions on seasonal labour migrants. Yet, the six-month limit for seasonal work was rejected by member states, which granted different periods of stay. The negotiations in the Council followed a similar pattern as member states found it very hard to reach a compromise. See Ryan (2007). The European Union and labour migration: Regulating admission or treatment?, in Baldaccini A., Guild E., Toner H. (eds). Whose freedom, security and justice? EU immigration and asylum law and policy. Hart Publishing: Portland, pp.497-500

${ }^{109}$ COM (2004) 811 final.
} 
policies through several mechanisms, such as developing a horizontal approach covering all types of labour migrants, creating 'sectoral agreements' for specific types of migrant or introducing a fast-track procedure for admitting migrants to cover specific labour and skill shortages in the EU. Although concerns about the viability of a sectoral approach to labour migration were voiced by members of the European Parliament and the European Economic and Social Committee (EESC), the Commission ultimately supported this policy design (Carrera et al. 2011.).

The Hague Programme ${ }^{110}$ on 'strengthening the area of freedom, security and justice' further stressed the idea that enhancing legal migration is an important instrument for developing the economy of the EU and achieving the goals of the Lisbon strategy. Nonetheless, it was clearly stated that the volume of third-country labour migration would be determined by individual member states.

The European Commission tried to increase supranational competences in the migration policy sector through its Communication "A policy plan on legal migration" 111 , which provided a roadmap and a set of actions for the coherent development of EU policy on legal migration. In contrast to the 2001 proposal, the document did not take an all-encompassing approach but addressed only certain categories of labour migrants.

Although a sectoral approach makes common immigration policies politically feasible, it complicates the coherent development of EU policies. In each case, clear-cut rules and a legal basis have to be identified that apply to each individual labour migrant, especially if he/she moves from one category to another (Collett 2009, p.37). Later in 2008 the European Council adopted a European Pact on Immigration and Asylum ${ }^{112}$, which attempted to develop a more comprehensive policy on labour migration.

The Stockholm Programme ${ }^{113}$, adopted in December 2009 by the European Council, reiterated the commitment of the Commission and the Council to implement the Policy Plan on Legal Migration, and recognized that labour migration can contribute to the economic competitiveness of the EU. The Action Plan implementing the Stockholm Programme provided for the adoption of a proposal for a directive on seasonal workers in $2010^{114}$.

Despite the development of EU migration policies in recent years, the only existing document at the EU level that directly deals with the admission of third-country seasonal workers is the Council Resolution of 1994 "on limitations on admission of thirdcountry nationals to the territory of the Member states for employment" ${ }^{\text {"115 }}$. The docu-

\footnotetext{
${ }^{110}$ European Council (2004) Presidency conclusions. Annex I. November 4-5

${ }^{111}$ COM (2005) 669 final

${ }^{112}$ European Council (2008) Presidency conclusions. 15-16 October

${ }^{113}$ OJ C 115/1. 4.5.2010

${ }^{114}$ COM (2010) 171 final.

${ }^{115}$ OJ C 274, 19.9.1996, p.3-6.
} 
ment includes elements of a definition of a seasonal worker ${ }^{116}$ and sets the maximum length of stay at six months ${ }^{117}$. Bertozzi (2010, p.9) shows that "despite the existing need for unskilled and low-skilled immigrant labour force, the immigration of unskilled and low-skilled workers is not addressed specifically at either EU levels or national levels". Ultimately, most member states do not have a specific system for regulating third-country seasonal workers. France, Germany, Italy, Greece, Portugal, Spain and the $\mathrm{UK}^{118}$ have introduced seasonal migration programmes for agriculture, tourism and the services sectors, which imply multi-entry permits and re-entry procedures. In general, these programmes attempt to establish guaranteed return and manage human mobility in a way that prevents settlement in a host country. At the same time, poor implementation of labour law standards, weak enforcement mechanisms and limited social rights linked to the temporary nature of the work all contribute to the risks that are inherent in seasonal labour migration (CEPS 2010) ${ }^{119}$. Some of these risks were addressed by the Proposal for a directive on seasonal labour migrants.

\subsection{Overview of the Proposal for a directive on seasonal labour migrants}

According to the European Commission, the key reason for launching a proposal for a directive (COM 20100379 final) are the shortage of labour in specific sectors of the economy and the risk of seasonal migrants' exploitation in sectors such as agriculture, horticulture and tourism. The proposal for a directive draws on articles 79.2 and 79.5 of the Lisbon Treaty, so member states decide for themselves whether they need thirdcountry labour migrants. The document establishes a common fast-track procedure (30 days) for the admission of third-country seasonal workers, precise admission criteria (article 5) as well as conditions for refusal to grant a joint work and residence permit (articles 6, 7).

The European Commission sets the maximum period of stay at six months in a calendar year, allowing migrants to change employers within this period. According to the Commission, the proposal for a directive complies with the principles of subsidiarity and proportionality, as it envisages a relatively small change from the status quo and gives member states a high degree of flexibility in implementing the new provisions. One of the elements of the proposal for a directive is article 16, according to which seasonal workers should be granted equal treatment in respect to the types of social

\footnotetext{
${ }^{116}$ Seasonal labour migrants are defined as workers who are resident in a third country but are employed in an activity dependent on the rhythm of seasons in the territory of a member state on the basis of a contract for a limited period and for specific employment.

${ }^{117}$ The person must spend at least six month outside the EU in order to be readmitted to the European Union

${ }^{118}$ The UK has ended its seasonal labour migration scheme for agricultural workers, see http://www.bbc.co.uk/news/uk-politics-24064774.

${ }^{119}$ CEPS (2010) Impact of the seasonal employment of third-country nationals on local and regional authorities. Bruxelles
} 
security listed in article 3 of Regulation (EC) $883 / 04^{120}$. One possible interpretation of article 16 is that seasonal migrants can have access to unemployment benefits. However, a staff member at the European Commission DG Home Affairs (B13) noted that, 'reference to regulation $883 / 04$ is put in as a matter of principle, but some rules are highly unlikely to apply in real practice'. The proposal for a directive was accompanied by an impact assessment, which was conducted in 2007-2008 ${ }^{121}$. The document once again stresses the need to establish a common EU procedure as member states currently have different admission schemes, definitions of seasonal labour and durations of applicable residence and work permits.

A staff member of DG Home Affairs (B13) stated that the European Commission did not get in touch with and was not contacted by national parliaments while developing the Proposal for a directive on seasonal labour migrants, the only exception being an information request from the Dutch Parliament's legal service. On the other hand, the European Economic and Social committee (EESC) made reference to the opinions of national parliaments while considering the European Commission's proposal. In fact, when the European Economic and Social committee first addressed the topic of seasonal labour migrants in 1997, it suggested involving national parliaments in developing an EU-wide legal framework for this type of labour migration ${ }^{122}$. In relation to the Proposal for a directive on seasonal labour migrants, the European Economic and Social Affairs Committee claimed that in order to take on board national parliaments' subsidiarity concerns, the duration of the residence permit should be defined at the national level ${ }^{123}$. The Committee of the Regions also made a reference to involving national parliaments in the debate, but it did not consider the Commission's proposal to have violated the subsidiarity principle. The Committee of the Regions underlined that EU legislation was necessary to prevent member states form engaging in a 'race to the bottom' ${ }^{124}$, that is, attempts by member states to obtain economic advantage over each other by decreasing the level of social protection available to seasonal migrants and making their labour cheaper.

The debate on the Proposal for a directive on seasonal migrants was much more heated in the European Parliament, where the Civil liberties, justice and home affairs

\footnotetext{
${ }^{120}$ This comprises the following benefits: sickness, maternity/paternity leave, invalidity, old age, survivors, accidents at work and occupational diseases, death grants, unemployment, retirement and family benefits.

${ }^{121}$ European Commission (2010) Commission Staff Working Document. Impact assessment accompanying the Proposal for a directive of the European parliament and of the Council on the conditions of entry and residence of third country nationals for the purpose of seasonal employment. SEC (2010) 887. Brussels 13.07.2010

${ }^{122}$ Opinion of the Economic and Social Committee on seasonal labour and migration in rural areas: stocktaking and outlook. Brussels. 1 October 1997

${ }^{123}$ Opinion of the European Economic and Social Committee on the Proposal for directive of the European Parliament and Council on the conditions of entry and residence of third-country nationals for the purposes of seasonal employment COM (2010) 0379. SOC/392. Brussels. 4 May 2011

${ }^{124}$ Opinion of the Committee of the Regions on seasonal workers and intra-corporate transfer. $89^{\text {th }}$ plenary session. 31 March-1 April 2011. CIVEX-V-014
} 
committee (LIBE) was assigned the dossier. The decision to make the LIBE committee responsible for the dossier, like the legal basis for the discussion in the European Parliament, was disputed. For example, members of the Employment and Social affairs committee (EMPL) suggested discussing the dossier on the basis of articles 153a and $153 \mathrm{~b}$ of the Lisbon Treaty (labour and employment). A member of the European Trade Union Confederation (ETUC) (B14), however, argued that some members of the EMPL committee feared that this legal base of negotiations would allow stakeholders and NGOs to play a greater role in the deliberations than MEPs. Ultimately, the LIBE committee prevailed in arguing for consideration of article 79 (migration) of the Lisbon Treaty as a legal basis for negotiations. The Legal affairs committee (JURI), which acted as an "arbiter" in the debate between LIBE and the EMPL committees, also agreed with using article 79, while the European Parliament Legal Service hinted that article $153 \mathrm{~g}$ of the Lisbon Treaty was the appropriate legal basis. According to the latter, seasonal labour migration belongs to a domain in which the Council of Ministers can act alone, without consulting other EU institutions. An assistant to an MEP from the European United Left-Nordic Green Left (GUE/NGL) Group (B37), who was involved in the negotiations, argued that in the course of negotiations the EMPL committee was not allowed to amend article 16 of the Proposal for a directive on seasonal labour migrants (social rights of migrants). This article stayed within the 'exclusive competence' of the LIBE committee, which could have downplayed the importance of social security issues in the debate over the directive.

National parliaments were not involved in the European Parliament's assessment of the directive. The only time MPs and MEPs came together to discuss the topic was at the LIBE committee meeting on the 29 November 2010. Members of the Czech Senate, the British House of Lords, and the Austrian Bundesrat and Nationalrat were present. There was limited interaction between MPs and MEPs; the two groups of parliamentarians simply reiterated their positions towards the Proposal for a directive. One of the MEPs stated that "if the national parliaments had a say - there would be no directive from the very beginning" "125. As Cooper (2013c, p.62) observes, in the subsequent deliberations on the dossier in the European Parliament, "the concerns of national parliaments were largely ignored"'. Several national parliaments openly doubted the addedvalue of adopting EU legislation in the domain of seasonal labour migration and considered this to be an infringement of member states' sovereign rights. On the other hand, the majority of MEPs was in favour of strengthening EU competences in this sector, although the specific wording and content of the proposed directive was a matter of debate between different EP party groups. In contrast to the wishes of national parliaments, EP committees overwhelmingly favoured the strengthening of the Proposal for a directive on seasonal labour migrants. Although the parliaments of Austria, Netherlands

\footnotetext{
${ }^{125}$ http://www.europarl.europa.eu/wps-europarl-internet/frd/vod/player?eventCode=20101129-1500COMMITTEE-

$\underline{\text { LIBE\&language }=\text { en \&byLeftMenu }=\text { researchcommittee \&category }=\text { COMMITTEE\&format }=\text { wmv } \# \text { anchor } 1}$
} 
and the Czech Republic as well as the House of Lords and the Polish Senate issued reasoned opinions against the Proposal for a directive on seasonal labour migrants, there were not enough votes to issue a 'yellow card'.

On 4 April 2011 Claud Moraes (LIBE committee; Group of the Progressive Alliance of Socialists and Democrats / S \& D), the rapporteur on the seasonal workers dossier, presented a working document on the Proposal for a directive on seasonal migrants. According to Moraes' report, the main thrust of the directive should be the protection of seasonal migrants from exploitation. Moraes points out several shortcomings of the Proposal, including an unclear range of policies to which it can apply and vague definition of 'adequate accommodation'. Another problem highlighted within the report is the lack of reference to recruiting agencies, which can both help promote legal and transparent migration and support exploitative practices. Although this was not mentioned in Moraes' report, experts stressed that the lack of instruments to guarantee the return of seasonal migrants was another potential challenge for the directive (McLoughlin and Münz 2011, p.34). The criticism voiced in Moraes' report was to a large extent repeated in a Joint NGO statement of 20 April $2011^{126}$. Guaranteeing social rights, reinforcing complaints mechanisms and even introducing provisions allowing for family reunification were among the concerns voiced by civil society actors.

During subsequent deliberations in the European Parliament, a number of amendments to the directive were proposed. Amendments by the rapporteurs, who came from the Group of the Progressive Alliance of Socialists and Democrats (S \& D), in both the LIBE and the EMPL committees, concentrated on sanctioning employers for using unregistered labour and setting precise criteria for what constitutes 'adequate accommodation'. Other amendments (from some S\&D and EPP / European People's Party members as well as non-attached MEPs) supported the introduction of compulsory labour market tests, which were meant to confirm that a position could not be filled by someone from within the EU. The scope of the directive was also contested, with suggestions made to include, for example, asylum seekers. Yet, for the Council and the Commission the only agreeable option would be to extend the offer of seasonal work to those thirdcountry nationals who are already residing inside the $\mathrm{EU}^{127}$. As a representative of PICUM (B34), an NGO involved in the deliberations on the seasonal migrants' dossier, argues, the suggestion to allow illegal migrants (the European Commission uses the term 'irregular') to apply for seasonal labour and work permits was highly contested in the European Parliament. In fact, a staff member of DG Home Affairs (B13) argues that if the European Commission had made such a proposal, it would have been stopped in its tracks by its own legal service.

Criteria for admission of seasonal labour migrants were also a matter of debate between the various political groups within the European Parliament. The Greens and

\footnotetext{
${ }^{126}$ EU Seasonal Migrant Workers' Directive: Full respect of equal treatment necessary. Joint NGO statement, 20 April 2011

${ }^{127}$ Author's participation in the NGO meeting dealing with the seasonal migrants' directive. 28.10.2011
} 
GUE/NGL suggested providing contracts in the mother-tongues of seasonal workers. The EPP party demanded the introduction of written commitments by seasonal labour migrants to return home. Opinions on the duration of stay varied between the EP party groups, from six months (ALDE / Alliance of Liberals and Democrats for Europe, part of EPP) to 9 months (GUE/NGL, part of EPP). There was also division on the possibility of granting seasonal labour migrants unemployment benefits (according to article 16). In the opinion of a shadow rapporteur (B15) involved in the negotiations, the $S \&$ D, Greens and ALDE were in favour, while the EPP and the European Conservatives and Reformists (ECR) were against this idea. The level of social rights that seasonal migrants could potentially claim remained a contentious issue throughout the negotiations. For example, a representative of the European Trade Union Confederation (B14) argued that although it was clear that the entire package of social rights could not be provided, third-country seasonal migrants should have the same amount of rights as resident workers, or double-standards would be encouraged. Given that member states have different criteria for obtaining social benefits, the aim of the proposal for a directive, to establish a common approach to entry and residence by third-country seasonal labour migrants, would be difficult to reach.

In May 2012 a vote was held in the LIBE committee (52 for, none against, one abstention) and the final version of the amendments was accepted ${ }^{128}$, which allowed the dossier to pass on to the Council. The amendments made reference to recruiting agencies and the sanctions that member states could take against employers. Apparently, as a way to assuage the worries of Romania and Bulgaria, the proposal for a directive claimed that "preference should be given to workers from Member States for whom transitional arrangements as regards access to labour market still apply". Ultimately, as a Romanian MEP testifies (B35), granting member states the right to introduce labourmarket tests was used specifically with the intention to protect the rights of Romanian and Bulgarian seasonal workers against potential wage-dumping from third-country nationals.

The field of application of the directive was restricted to agriculture, horticulture and tourism, but member states were given the right to expand its scope after consulting with stakeholders. The duration of a seasonal work permit was set at six months in a 12 month period. Provisions on 'adequate accommodation' were included, although no clear definition was given. The controversy over article 16 was also addressed, albeit in a rather vague manner. It was proclaimed that equal treatment should be granted (referring to regulation $883 / 2004$ ) to seasonal migrants, while member states were obliged to establish effective mechanisms for social security coverage and the transferability of social rights if individuals moved between EU member states. According to the amendments, each member state was responsible for defining the conditions, scope (pension rights are mentioned) and duration of granting social security benefits. It was explicitly noted that the directive does not seek for more harmonization, although

${ }^{128} 2010 / 0210(\mathrm{COD})$ 
"when exercising that power to organize social security schemes member states should comply with Union law".

The vote in the LIBE committee sought to indicate a broad consensus among MEPs, which resulted in some of the provisions of the document being quite vague. However, representatives of NGOs (B34) and staff members at the European Commission (B32) argue that the MEP's input made the proposal for a directive more 'migrantfriendly'. For example, amendments envisaged by the MEPs allowed applications for seasonal work permits from both outside and inside the territory of the EU, 'illegal' migrants (the Proposal for the directive uses the term 'irregular') could also use the scheme during a 'transitional period'.

Negotiations over the seasonal migrant dossier started in the Council in mid-2012 but agreement among member states was reached only in February 2013. The Council's variant of the document allows member states to introduce labour market tests and determine the scope of the directive's application, as well as the length of migrants' stay. It is explicitly stated that no harmonization of social security provisions will be conducted. Member states stressed that equal treatment of third-country nationals does not apply to family benefits and unemployment benefits. In fact, the Council's approach is closer to the critical positions of national parliaments than to the stance of the MEPs. A staff member at the Migration Policy Institute (B12) argued that the Council's attitude reflects the scepticism of member states such as Spain, Germany, Romania and Bulgaria towards the Commission's proposal.

In early 2014 the European Parliament and the Council reached agreement on the text of the proposal for a directive on seasonal migrants ${ }^{129}$. Applications to the seasonal labour migrant scheme were allowed only from outside the territory of the EU, while illegal migrants were not allowed to participate at all. Member states also acquired the right to introduce labour market tests. The document stressed that the seasonal migrant scheme is based on the principle of 'equal pay for equal work', but equal treatment of third-country labour migrants would not apply to certain types of social security such as unemployment benefits and family benefits. Any application of the directive to family reunification was ruled out. Third country nationals were allowed to change employers during their stay but it was stated that "the directive should not entail the possibility for the seasonal worker to seek employment on the territory of the Member States while being unemployed". In general, the final version of the document provides a number of guarantees against the abuse and exploitation of seasonal workers by their employees, but it clearly attempts to restrict migration and access to social security benefits by third country nationals. Despite the fact that the final text of the proposal for a directive abandons some controversial elements regarding migrants' access to welfare, the docu-

${ }^{129}$ P7_TA-PROV(2014)0072; Seasonal workers directive: improvements for treatment of non-EU workers, but not enough to prevent exploitation, PICUM, 14 November 2013 (http://picum.org/picum.org/uploads/file_/14.\%20Nov.\%202013\%20Joint $\% 20$ release $\% 20$ seasonal $\% 20$ workers\%20directive_ENAR $\% 2$ C $\% 20$ FEANTSA\%2C\%20PICUM\%20FINAL.pdf) 
ment can still affect national migration regimes or at least contribute to the domestic debate on migration issues, and trigger changes in national labour migration regulation.

\subsection{Labour migration policies in Sweden}

Sweden began introducing stricter regulation of labour migration in the 1980s, while at the same time launching an extensive integration policy for migrants. A hallmark change took place in 2003-2004, when the committee for labour migration (KAKI) ${ }^{130}$, under the guidance of centre-right parties and the Green Party, pushed for the development of a new policy regime for non-EU labour migrants. The debate on reform started in 2001 when the Swedish Confederation of Enterprise (SN) published a report "Globalization and the Labour Market: Open the Swedish Labour Market" (the Fahimi report). The focus of the report was on restructuring the work permit approval system in such a way that employers and not state authorities would have the biggest influence on granting jobs.

The public debate was further triggered by the presentation of another SN report, the so-called Ekkenger-Wallen report "Immigration for growth and new jobs" during Almedalen week ${ }^{131}$ in 2002. The document contained a number of proposals which were more radical than the Fahimi report: a three-month entry permit to seek a job, full access to social security on commencement of employment, the granting of work permits to foreign students, issuing work permits which are not limited to specific occupations, and making permanent residence available after spending three years in the country. The document reiterated that the needs of business and not desire to treat migration in the context of reducing domestic unemployment should steer Swedish policy.

In the same year, the Liberal Party (a member of the Alliance coalition of centreright parties) launched an investigation into the possibilities of a new labour migration policy, taking a lot of inspiration from the Ekkenger-Wallen report. Their main suggestions were the introduction of a five-year period before an automatic granting of permanent residency, the provision of a three-month residence permit to secure a new job and the step-by-step granting of social benefits. By the end of 2002, the Greens and a number of centre-right parties had begun to shift their policy preferences towards the Liberals' project.

The Social Democrats and their 'associated' trade union, LO, criticized these proposals, claiming that they were incompatible with the drive to reduce unemployment. They argued that relaxing rules for labour market entry could put the 'Swedish social model' in danger and lead to the establishment of a guest-worker system. Moreover, any changes to the labour migration scheme were likely to limit the influence of trade un-

\footnotetext{
${ }^{130}$ The committee was convened by the Swedish government but was not part of the ministerial structure. It served as a platform for high-profile negotiations between various political parties on the issue of labour migration policy reform.

${ }^{131}$ An annual forum dedicated to Swedish politics.
} 
ions and be unpopular with left wing voters. The victory of the Social Democrats in the general elections of 2002 halted the progress of migration policy reform. Nonetheless, in 2003, under pressure from the Green Party and centre-right parties, the Social Democrats had to accept the creation of a committee for labour migration, which would serve as a platform for high-profile consultations among political parties. The new body worked on the basis of a report by the Green Party, "Labour migration with social responsibility", which was close to the Ekkenger-Wallen document ${ }^{132}$. The Social Democrats agreed to the creation of the committee, but insisted that representatives of the Green and centre-right parties would be in a minority on the committee, effectively obtaining a veto on any decision which did not suit them.

The first report of the committee appeared in 2005, but was primarily a review of stakeholders' opinions. In 2006, the centre-right parties were unable to reach consensus with the Liberal party, so the next annual report drew mainly on insights from the Social Democrats and the Left Party. For example, granting access to the labour market was to be done only through the Swedish National Labour Market Board (AMS), which was to determine the sectors experiencing a shortage of labour that could not be filled from inside the EU.

The election victory by the centre-right parties in late 2006 made the situation more conducive to reform. In 2007, the Minister for Migration, Tobias Billström, reinvigorated the work of the committee for labour migration, proposing to relieve the Swedish National Labour Market Board of its traditional 'gatekeeping' functions in the migration sector. The minister's proposal served as a basis for the final report of the committee in 2008. The governing Alliance (centre-right) and the Green Party (opposition) supported the document, while the Social Democrats and the Left Party voted against, concerned by potential wage-dumping and alleged possibilities for migrant exploitation.

In contrast to the previous policy regime, the trade unions were now to be consulted only in order to ensure consistency of employment contracts with collective labour agreements. They were to lose their de facto veto powers on the employment of thirdcountry nationals. The new law stipulated that continued employment for a period of four years would result in a permanent settlement visa. As a result of these changes, the employment procedure for a Swedish citizen and a third-country national became much more similar (Bucken-Knapp 2009). Employers rather than unions were given the 'gatekeeping' function in the national labour market. This amounted to a paradigm shift as the restrictive rules on third-country labour migration established in 1970s were abolished.

Despite this comprehensive labour migration reform, Sweden has no specific regulation pertaining to unskilled and low-skilled workers. Their status is regulated according to the Swedish Aliens Act of 2005 and Swedish Aliens Ordinance of 2006, as well

\footnotetext{
${ }^{132}$ The only difference being that it was suggested that permanent residence should be granted after one year of employment.
} 
as subsequent procedural amendments introduced after the 2008 reform (Bertozzi 2010, p.103-106). According to the European Commission's assessment ${ }^{133}$, Sweden experienced an increase in the number of seasonal workers before the onset of the economic crisis (from 496 in 2005 to 7259 in 2009), but it is hard to define their precise number because seasonal workers are generally not included in the statistics of the SCB (Statistics Sweden). As they normally come for less than one year, they are not recorded on the population registry. The number of seasonal workers began to decline in 2010 due the impact of the economic crisis, and there was an even sharper decline in the number of "agricultural, fisheries and related labourers" in 2011 (data for January-May). Representatives of the Swedish Migration Board (S18) as well as the Ministry of Justice (S25) explain this change by the introduction of stricter rules dealing with the provision of financial guarantees of workers' salaries. As a result, problems with securing an inflow of third-country nationals led to a greater influx of Bulgarian and Romanian workers, but it is nearly impossible to obtain statistics on their numbers.

The first overview of the new labour policy was published in 2009 (Cerna 2009). It showed major fluctuations in the number of work permit allocations throughout the year due to the substantial number of seasonal workers. A report published by the OECD (2011) claims that there is a 'high concentration' of employers in the seasonal work track: in 2009 and 201075 per cent of all permits in this area were given by just five employers.

The European Commission's proposal for a directive on seasonal labour migrants puts pressure on Sweden as it adopts a totally different, sectoral (as opposed to holistic) approach to regulating labour migration. Another important point of contention is the introduction of labour market tests which, according to the final version of the directive on seasonal migrants, member states will be allowed to introduce. This means that the Social Democrats and the LO trade unions could attempt to return migration policy to its pre-2008 status quo, where the role of national stakeholders was much greater. The Social Democrats are likely to support trade unions' aspirations to reintroduce labour market tests as this would secure their political support in the upcoming general elections. On the other hand, it should be acknowledged that despite the possibility of using the directive to increase trade union influence in the labour migration regime, as experts from SIEPS (S17) argue, in the opinion of a staff member of the Swedish Permanent Representation (B30) it would be hard to reverse the current system. Commenting on labour migration policies, a staff member of the centre-right Moderate party (S13) argued that the trade unions and the Social Democratic Party would not so much promote a full-scale return to the old system but look for opportunities to increase their control over recruitment practices within the current framework. For example, a representative of the Swedish confederation of professional employees (TCO trade union) (S33) stated that at the beginning of 2012 the spokesperson of Social Democrats for labour market affairs, Ylva Johansson, had claimed that the party would not campaign for the reintro-

${ }^{133}$ SEC (2010) 887 final. 13.07.2010 
duction of labour market tests. This, however, may have changed as in 2013 the leader of Social Democrats, Stefan Löfven, started to make increasingly critical statements about the current labour migration regime.

Although access to unemployment benefits for seasonal migrants has been ruled out in the final text of the directive, the topic of welfare provision to migrants in general will remain controversial. The issue could be raised again during the transposition process. In Sweden the number of long-term recipients of welfare benefits has grown (Mood 2011), and the idea of granting migrants full-scale access to welfare might be considered illegitimate. On the other hand, the content of article $16^{134}$ and the issue of labour migrants' access to social security has largely been outside the focus of political parties. A respondent from the Social Democratic Party (S11) suggested that the impact of article 16 on social security provision in Sweden is likely to be limited. It was acknowledged that an alternative reading of this provision "could trigger a domino effect", meaning that granting, for example, unemployment benefits to seasonal migrants from third countries could raise questions about their eligibility for the full spectrum of socio-economic rights that EU nationals enjoy. The Green Party, according to its representative (S5), would not object to a 'broad' reading of article 16, but granting seasonal labour migrants unemployment benefits could in any case provoke political controversies. In Sweden unemployment schemes are run by trade unions, so this group of stakeholders would also be affected, especially given the fact that the European Parliament and the Council agreed to provide seasonal migrants with a right to strike and join trade unions. Representatives of the Swedish Confederation of Enterprise (S21) argue that it would be complicated for employers' organizations to come to terms with the provisions of article 16, as they raise too many technical questions about criteria for access to unemployment benefits. Despite the fact that any seasonal migrant is likely to find applying for unemployment benefits a complicated matter, an outright formal exclusion of this possibility would be problematic, according to a representative of the Swedish confederation of professional employees (S33).

Far-right political parties have had very limited impact on the Swedish Government's labour migration policy (Collett 2011). Currently, only the radical right- and left-wing parties such as the Sweden Democrats and the Left Party, respectively, mobilize their voters on migration issues. All other parties limit reference to migration in their political discourse. In the opinion of a Swedish academic expert (S31), this amounts to a conscious attempt to depoliticize the issue of migration. Another respondent, a journalist from the Dagens Industri (S37), argues that "migration is not an issue for mainstream parties". Ultimately, the intentional "depoliticization" of migration policy has been used to limit the level of inter-party conflict and the influence of the farright Sweden Democrats, but certain provisions of the directive touch on core elements

\footnotetext{
${ }^{134}$ Reference is made to article 16 of the draft directive, not article 23 of the final version of the document, as the parliamentary respondents interviewed in 2011-2013 only had access to the draft proposal for a directive on seasonal migrants.
} 
of the Swedish labour migration regime and political parties' preferences. What at first glance might be considered a conflict between the EU and national spheres of competence also fits into domestic political debates, as the 2014 elections will necessarily contribute to increased polarisation among all political parties.

However, the proposal for a directive on seasonal labour migrants has a number of loopholes that would allow Sweden to circumvent it. For example, many seasonal berry-pickers from Thailand are formally posted workers, as they are employed by third country companies, which later sign contracts with Swedish business partners and then send workers to Sweden. This classifies 'seasonal labour migrants' as 'posted workers', so the directive would not be applicable to them, which was confirmed by members of the Swedish Migration Board (S18), respondents associated with both Swedish government (S13) and opposition (S24) parties, as well as the European Commission (B32). However, some researchers (Woolfson, Olsson and Thörnqvist 2012) consider the case of berry-pickers from Thailand an example of the forced labour which can exist due to the deficiencies in both Swedish and EU law. In any case, the directive contributes to the domestic political debate about the rules of access to the Swedish labour market.

\subsection{Labour migration policies in the Czech Republic}

In the Czech Republic, there is no regulation targeted directly at third country, lowskilled seasonal labour. The two main documents dealing with the admission of third country nationals to the Czech labour market are Act No. 435/2004 Coll. on employment and Act No.326/1999 Coll. on the residences of foreign nationals on the territory of the Czech Republic. Employment of third country nationals is subject to a labour market test and there are separate work and residence permits (Bertozzi 2010, p.27-29).

The Czech statistical services do not possess exact data on seasonal labour migrants, although there is indirect evidence that low-skilled workers formed the largest labour migrant group in 2006-2009. The Czech authorities monitor the number of work permits handed out for the purpose of seasonal labour, but seasonal migrants often obtain a job through an ordinary work permit. Non-EU nationals play an important role in low-skilled and unskilled jobs, making up around 25 per cent of the total number of employees in this sector in 2008, the majority coming from Vietnam and China. A representative of a Czech trade union association (C32) argued that many are illegally employed in the forestry sector, but there is comparatively little demand for this type of workers in agriculture.

The Ministry of the Interior is currently drafting a new law on migration, but it is unlikely to make the legal situation any clearer as it envisages several types of visa and work permit for low-skilled migrants. This will not bring seasonal migrants out of the 'grey' legal zone or resolve the contradictions between existing legal acts. For example, as an NGO expert (C26) on migration has noted, the Czech law on residents does not mention seasonal migrants at all, while the law on employment refers to seasonal labour 
migrants in the context that their permits should be no longer than six months. There could also be other problems with implementing some provisions of the Proposal for a directive. For example, the Ministry of labour is supposed to conduct labour market tests, but both journalists (C14) and NGO experts (C26) confirm that in practice this rarely happens and civil servants have no specific instructions on how these tests are to be conducted. One of the journalists interviewed (C14) referred to turf wars between the ministries of labour, the interior and social affairs, which would also inhibit legal clarity and impartial implementation of the directive.

According to a respondent from the Association for Integration and Migration (C26), a strong sign of a move towards a restrictive migration policy is the decision by the Czech ministry of labour to stop renewing labour permits for low-skilled migrants from July 2012. In the opinion of an expert from the International Organization for Migration (C19), this is a populist measure as statistics do not support the idea that migrants contributed to rising unemployment.

At the same time, migration issues have not proved politically divisive in the current public debate. Migration issues have not really appeared on the radar of Czech political actors, which has so far prevented the development of far-right sentiments. However, it also leaves an important political issue unaddressed. For example, according to an expert from an NGO (C19), there are only two or three MPs and senators in the Czech Parliament with a distinct interest in migration issues.

The level of 'migrant integration' in the Czech Republic is low (Nowaczek 2008) and the issue of providing migrants with social benefits may be politically contentious. An expert from the Association for Integration and Migration (C26) argues that in principle seasonal migrants could be eligible for six-weeks maternity leave, although after this period the work or residence permit is normally revoked as a person is considered not to have fulfilled their contractual obligations. In addition, the directive grants seasonal migrants the right to switch employers during their period of stay, which contradicts the current Czech regulations. The Czech authorities would also need to start issuing joint work and residence permits, which goes against existing Czech practice.

Ultimately, the relatively 'migrant-friendly' provisions of the proposal for a directive on seasonal migrant labour run counter to the restrictive policies of the Czech Government. Implementation of the directive would require an overhaul of a large number of bureaucratic practices. Even limited access by seasonal migrants to social security is likely to be controversial. This could contribute to increased politicization of migration issues in the Czech Republic.

\subsection{Labour migration policies in Romania}

Romania does not have specific policies aimed at regulating the entry and work of third country, low-skilled labour. The status and employment of third country nationals is regulated by two ordinances: 194/2002 and 56/2007. The government establishes an 
annual quota of work permits to be issued to third country nationals. For example, in 2010 of the 8000 work permits allocated, 400 went to seasonal workers. These annual quotas are determined in tripartite negotiations between the government, trade unions and employers, but it is the Romanian Office for Immigration that makes the final decision. Hence, coordination between various layers of the bureaucracy is often difficult (Alexe 2010, p.211-217). At least in theory, the employment of third country nationals is subject to labour market tests, although it remains unclear how and whether these tests are actually conducted. Migrants are not part of trade unions, which could be redressed with the entry into force of the directive on seasonal migrants. Seasonal workers can potentially be hired through the 'daily labourer' scheme, but this means that they do not pay any social contributions and remain outside the social security system.

According to experts from a non-governmental organization (R16, R17), thirdcountry labour migrants could become a topic for public debate in Romania. For example, abuses of Philippine, Chinese or Bangladeshi workers through unregulated working conditions, or locking up, gerrymandering contracts and deportation in case of employer insolvency, have caused a lot of frustration and tension in the Romanian textile industry. The adoption of the directive could curb such abuses, but how the document will be implemented remains to be seen. Romania is considered to be more of a transit route to Western Europe than a 'final destination' of its own. In the opinion of one academic expert (R7), it is also probable that a substantial number of those who are registered as unemployed in, for example, Spain might be Romanian, so the impact of their return home on the Romanian welfare system could be very high. NGO experts (R16, R17) argue that in a few years Romania might need agricultural workers from third countries as, according to evaluations by experts from the Friedrich Ebert Stiftung (R20), internal mobility is almost non-existent. From an interview with a staff member from the Romanian Permanent Representation (R31), it seems that the key official concern with the proposal for the directive is how the document might affect Romanians working elsewhere in Europe, for example, through potential wage-dumping and/or better social conditions for third-country migrants. As an NGO expert (R16) has mentioned, in a situation where 65 per cent of the Romanian unemployed do not receive social support, it is hardly possible that third country nationals who lose their job would receive any. Hence, the provisions of the directive dealing with welfare benefits will be difficult to implement.

Ultimately, in the Romanian case, the saliency of the proposal for a directive is not linked to national political actors using it as leverage to reconsider the domestic status quo. The directive is important in the light of attempts to secure a niche for Romanian seasonal workers in the EU job market against competition from third country nationals, and to avoid any social security obligations that the government might have towards third country workers. 


\section{CHAPTER 5: Parliamentary scrutiny of EU affairs in the Swedish Riksdag}

This chapter shows how in the aftermath of the Lisbon Treaty the Swedish Parliament further strengthened its decentralized scrutiny system, which encouraged the involvement of sectoral committees in EU affairs. Political parties played a crucial role in shaping the scrutiny process in the Swedish Riksdag by resisting attempts by parliamentary administrators to reform the rules of procedure and keeping parliamentary committees, including the European Affairs Committee (EAC), under partisan control. By focusing on the interaction between parliamentary actors during the assessment of the Green Paper on pensions and the Proposal for a directive on seasonal labour migrants, this chapter analyses the evolution of parliamentary scrutiny of EU affairs in the post-Lisbon environment.

\subsection{Evaluation of EU proposals on pensions and labour migration policies in the Swedish Riksdag}

In July 2010, under the rules of procedure of the Swedish Riksdag, the Green Paper on pensions was referred to the Committee on Social Insurance. In the Swedish Parliament, sectoral committees are in charge of scrutinizing EU Green Papers or White Papers and conducting subsidiarity checks. The European Affairs Committee is involved in cases when a mandate on the government is required. The Green Paper was put on the agenda of the EAC in October $2010^{135}$, but it was not discussed in any detail. A representative of the government made a brief statement concerning the Swedish position and the meeting moved on to other items on the agenda. The resolution from the Committee on Social Insurance, on its evaluation of the Green Paper, was debated and adopted in November $2010^{136}$.

This resolution stated that the Riksdag shared the concerns of the European Commission about the current challenges facing national pension systems. All the political parties in the Riksdag, however, firmly supported the idea that social security systems were part of the remit of the member states. The resolution echoed the government's position that sharing 'best practices' and coordination among member states in the welfare sector was possible, but pension policy should remain its sovereign responsibility.

The resolution of the Committee on Social Insurance contained an addendum in which the position of the Left Party was spelled out. Although the Left Party supported

\footnotetext{
${ }^{135}$ Stenographic records of the EAC meeting 2010/11:2

${ }^{136}$ Statement 2010/11:SfU5
} 
the key message of the resolution that the competences of the EU in the social security sector should remain limited, it wanted to stress its disagreement with the design of the current Swedish pension system. It criticized the Swedish pension scheme for allegedly discriminating against women as well as its inability to address the social exclusion of pensioners. Moreover, it stressed that the Swedish pension system is too dependent on returns from stock market investments. In the opinion of the Left Party, a mistaken investment strategy and the volatility of stock markets could jeopardize Sweden's ability to provide adequate pensions. According to a member of the Left Party (S1), the reason for including the addendum was to inform domestic stakeholders as well as to reassure its core voters that the party remained true to its critical approach to the Swedish pension system.

The main thrust of the arguments voiced during debates in the Committee on Social Insurance was that the EU should have as little competence as possible in the sphere of social security. As a member of the Swedish Parliament (S36) who was involved in the assessment of the Green Paper stated: "There was some criticism from the Green and the Left Party but no big reservations, not much debate because the Green Paper is 90 per cent description, not prescription.... Both party ${ }^{137}$ and committee were clear that the EU should not prescribe any details, for example on the adequacy of pensions. The Green Paper was not very detailed but some formulations were risky, we would not accept them". In the opinion of most MPs, the Green Paper did not merit further assessment because the document did not make detailed policy proposals. As a result, the debate in the Swedish Riksdag did not prove controversial. It is important to note that parliamentary staff did not develop an 'impact assessment' for the scrutiny of the Green Paper on pensions in the Riksdag.

As a follow-up to the debate on the Green Paper, the Riksdag briefly assessed the White Paper on pensions. It is noteworthy that the Riksdag considered the document only in the Spring of 2013, almost a year after its publication. The file was referred to the Committee on Social Insurance of the Swedish Parliament ${ }^{138}$, but "the eight parties totally agreed that the pension issue is not an EU matter. Therefore there was no debate about this" (S2b). The topic was not discussed further in the Riksdag European Affairs Committee.

The Proposal for a directive on seasonal labour migrants was referred to the Committee on Social Insurance in September $2010^{139}$. The discussion in the Committee on Social Insurance was very brief, as MPs were not willing to engage with the content of the proposal to any great extent. "When it became clear that there was no subsidiarity breach, the scrutiny was over" (S2a). Only the division of competences between the EU

\footnotetext{
137 The respondent makes reference to his own party, the Liberal Party, which is a member of the Alliance governing coalition

${ }^{138}$ 2011/12:SfU15

${ }^{139}$ The opinion of the Swedish EAC on the proposal for seasonal labour migrants is not available on the IPEX webpage; Minutes (although not the stenographic record) of the meeting are available from the website of the Committee on Social Insurance under heading 2009/10:33
} 
and Sweden was addressed. As with the Green Paper on pensions, the staff of the Committee on Social Insurance did not develop a preliminary 'impact assessment' of the proposal for a directive. One day after the Proposal for a directive on seasonal labour migrants was discussed in the Committee on Social Insurance the topic was raised in the EAC, ${ }^{140}$ as negotiations on the Proposal were being conducted in the Council of Ministers. The discussion in the EAC centred on the ability to safeguard the Swedish labour migration system from unwarranted EU influence

Representatives of the government were present during the debates in the Committee on Social Insurance and the EAC. Members of all the political parties and government officials were of the same opinion - that further development of the EU's competences in the field of social security was not necessary. It is important to note that even a respondent from the opposition Social Democratic Party (S32) argued that the main concern in the discussion of the Proposal for a directive on seasonal migrants (as well as the Green Paper) was to prevent excessive EU interference in the 'Swedish system'. A similarly negative attitude was shared by key stakeholders, although the representative of the Swedish Confederation of Professional Employees (TCO) (S33) argued that the key flaw in the proposed directive was its inability to sufficiently protect the rights of third country workers, not just unnecessary EU interference in Swedish affairs. The abovementioned respondent claimed that the directive "combined bureaucracy with the desire of interior ministers to keep control with no sufficient protection of workers' rights".

Ultimately, the process of parliamentary scrutiny of the Proposal for a directive on seasonal labour migrants and the Green Paper on pensions did not go into much detail, and the potential repercussions of these documents for the Swedish pension system or labour migration regime were left unaddressed. It is noteworthy, however, that the Riksdag European Affairs Committee closely followed the arguments of the Committee on Social Insurance in its own deliberations. Such collaboration between the European Affairs Committee and other sectoral committees is a hallmark of the Riksdag rules of procedure.

\subsection{Domestic rules of procedure, material and temporal constraints}

The Lisbon Treaty did not trigger a comprehensive overhaul of the Riksdag rules of procedure. The necessary formal changes were enacted following reports by the Committee on the Constitution ${ }^{141}$ and the Board of the Riksdag ${ }^{142}$. The key changes took place in 2007 , before the entry into force of the Treaty ${ }^{143}$. In anticipation of the Consti-

\footnotetext{
${ }^{140}$ Stenographic records of the EAC meeting 2009/10:54

${ }^{141} \mathrm{KU} 2009 / 10: 2$

${ }^{142}$ SOU 2008/09:RS4

${ }^{143}$ Report from the Swedish standing committee on the Constitution, 2006/2007: KU3; Record of proceedings in the Chamber 2006/07:35
} 
tutional treaty, the Riksdag decided to devolve subsidiarity checks to sectoral committees, integrating them fully into the scrutiny of EU affairs. The subject of an EU proposal determines which committee is responsible for conducting subsidiarity control. Decentralization of the scrutiny system was further promoted by the fact that the Riksdag refers the decision on blocking or accepting the use of the 'passerelle clause" ${ }^{144}$ to sectoral committees. Reports by sectoral committees on the application of the 'passerelle clause' must be debated in the plenary, but they are unlikely to be overturned as the proportional composition of committees in the Riksdag makes them function as if they were miniature versions of the plenary. The role of the European Affairs Committee is primarily focused on the coordination of sectoral committees and deliberation with the government before Council meetings, although the mandate which it provides is only politically binding (Hegeland in Maurer and Wessels 2001). When the European Affairs Committee issues a mandate it represents the position of the whole Riksdag.

None of the abovementioned aspects have been altered in the aftermath of the Lisbon Treaty. The decentralized character of the Swedish scrutiny system has remained unchanged, and proposals to reform the scrutiny procedure were rejected. The debate over the report of the working group on EU affairs (EUMOT) provides an interesting example of how reform of procedural rules was resisted.

The EUMOT was first convened in 2009 , to consider potential scenarios for scrutiny system reform. It was comprised of parliamentary administrators and no representatives of political parties were involved in its work. The group presented its report in $2011^{145}$. It proposed a number of scenarios for scrutiny reform, such as abolishing the European Affairs Committee altogether and providing standing committees with a right to define the mandate of the Swedish Government during negotiations in the Council of Ministers. An alternative option was to reduce the number of standing committees to 11, to mimic the Council structure, while giving newly forged committees competences to mandate the government. The third option was the so-called 'asymmetric solution', in which only the committees on agriculture, the environment and finance would acquire mandating powers while the European Affairs Committee would be responsible for providing a mandate in other policy areas. According to a staff member of the Riksdag (S3) who was involved in the EUMOT working group, the revamped European Affairs Committee would focus on the agenda of the European Council summits and sessions of the General Affairs Council, as well as matters concerning EU funds.

Despite the fact that recommendations of the EUMOT committee were not taken up, they highlighted an important trend in the evolution of the Swedish scrutiny system - the slow dilution, if not marginalization, of the European Affairs Committee's role as it focuses more and more on mediation and providing a mandate on the basis of the

\footnotetext{
${ }^{144}$ See chapter 3 for the definition of the 'passerelle' clause

145 One report (2010/11:URF2) dealt specifically with EU affairs scrutiny, the other (2010/11:URF3) with organizing standing committees' work
} 
opinions received from the sectoral committees. The trend for the decentralization of scrutiny powers existed before the Lisbon Treaty as well as after its entry into force.

In the aftermath of the Lisbon Treaty, the scrutiny system in the Riksdag has retained its focus on Green Papers and White Papers, which allegedly allows the Riksdag to engage as early as possible in the EU policymaking process (Hegeland and Neuhold 2002). Current practice was introduced by the 2007 reform, but there is a growing weariness about the focus on Green Papers and White Papers among both left and right in the Swedish Parliament (S2a, S11, S26). As a member of the Riksdag administration (S22) commented, it is hard to make MPs invest time in scrutinizing non-legislative documents, while standing committees often simply avoid debates on such papers. On the other hand, disillusionment about the added value of Green or White Papers has not led to a determined attempt to overhaul the scrutiny system. The idea of reporting exclusively on legislative proposals and to drop the focus on non-legislative documents has been resisted within the Riksdag, for example by the Committee on the Constitution. In the opinion of one of its staff members (S35), this would contradict the key role of the Swedish Government in defining the national position on EU proposals. Despite the fact that the resources spent on scrutiny can be considered 'lost' if a Green or White Paper does not become a legislative proposal, it is acknowledged that it at least keeps MPs acquainted with EU issues and can potentially help influence the EU decisionmaking process at an early stage. However, as a former member of the Riksdag (S38) claims, this opportunity seems to have rarely been used in practice, and 'early influence' remains a theoretical possibility not a tested mechanism.

In the post-Lisbon environment, the Swedish scrutiny system has focused on the division of competences between the EU and national governments. For example, reports by the Committee on the Constitution ${ }^{146}$ claim that although it might occasionally be hard to distinguish between the issues of proportionality and subsidiarity, scrutiny primarily addresses the division of competences between the EU and the national levels, without focusing on the content of the proposals or their desirability. On the other hand, this focus can be justified. As one of the Riksdag staff members says (S22), "it is not the eight-week timeframe that is the challenge ${ }^{147}$ but the delineation of EU and member state competences". Hence, the attention paid to these issues is legitimate in terms of streamlining the scrutiny process. Nonetheless, a staff member of the Riksdag (S6b) dealing with EU affairs acknowledges that if the content of an EU proposal does not seem to pose any direct problems, it can be overlooked, which reduces the leverage of the Swedish parliament.

It could be said that the Riksdag has consistently resisted obtaining stronger control over the government in EU affairs. For example, during the set-up phase of the Swedish scrutiny procedure, the Riksdag Committee on the Constitution objected to adopting the Danish practice of issuing legally binding mandates, suggesting a more flexible ap-

\footnotetext{
${ }^{146}$ 2010/11:KU18, 2011/12:KU4, 2013/14:KU5

${ }^{147}$ Challenge for conducting subsidiarity checks
} 
proach (Gustavsson 1996). Reviews of the parliamentary scrutiny system for EU affairs conducted in the early $2000 s^{148}$ reiterated the argument that the Riksdag should not issue a legally binding mandate. In the aftermath of the Lisbon Treaty, the same argument was repeatedly evoked by the Riksdag Committee on the Constitution (Larue 2011).

According to parliamentary staff members, it was not only the design of the Swedish scrutiny system that saw little change in the aftermath the Lisbon Treaty but also the administrative support system for dealing with EU affairs (S28, S35). Members of the Riksdag administration state that no extra staff were hired in the aftermath of the Lisbon Treaty (S6a, S28b). The last major intake of administrators took place in 20062007, when four or five new people were hired, although they were not involved exclusively in working on EU issues. Currently, the staff of the European Affairs Committee secretariat consists of seven people: a head of secretariat, three deputy-secretaries, two assistants and one 'semi-assistant'.

At the same time, it is hard to establish the exact number of the Riksdag staff who deal with EU affairs. Since the Lisbon Treaty, each standing committee has a staff member responsible for the 'EU section' of a respective policy area, although by and large all members of parliamentary staff come across EU topics. The Riksdag has also set up an EU coordination Unit ${ }^{149}$ but its key function is streamlining document distribution and the administrative workload, not policymaking or providing expertise. The majority of the Riksdag members interviewed - from both the governing coalition and opposition parties - argued that the number of parliamentary staff who deal directly with EU affairs does not need to be increased. This view is shared by a staff member of the European Affairs Committee secretariat (S4), who argued that "more people would not necessarily make things work better". One of the reasons for the lack of new staff could be the fact that MPs do not consider it necessary to invest resources in the scrutiny system as they do not obtain 'voting points' for EU affairs, as a staff member of the Green party put it (S5).

To a large extent, the Riksdag still depends on information provided by the government. For example, after a Council meeting the government is obliged to produce a report on Sweden's final position, although the quality of these reports tends to vary considerably (Raunio and Wiberg 2008). A member of the parliamentary administration (S6a) argues that regardless of these shortcomings, there have been hardly any occasions when acquiring information or its quality constituted a real problem. Between 2006 and 2010, government memoranda were delivered on time in in 80 per cent of cases $^{150}$.

\footnotetext{
${ }^{148}$ RS 2000/01:1, KU 2000/01:23

${ }^{149}$ Strictly speaking this is not a unit but four or five people spread over several departments, albeit linked by a common function.

${ }^{150}$ 2010/2011:URF2
} 
There is some scepticism about the ability of the Riksdag to conduct effective scrutiny of EU affairs, primarily due to its limited administrative resources. Some experts, for example Madell (in Iglesias and Blanco 2010), argue that document overflow and limited upgrading of the administrative/expert support system have not been accorded enough attention. In support of Madell's view, it is possible to say that the Riksdag Research Service (RUT) is almost never involved in the scrutiny of EU affairs, which can be considered a handicap. In fact, the body is much more used to providing expertise on domestic politics, as was confirmed by all respondents. For example, a staff member of the Green Party (S5) argued that in EU affairs the RUT "does not provide any information that you cannot find for yourself". The low level of involvement of the RUT in the scrutiny of EU affairs can be explained by the specific functions of the body, as it focuses on the provision of factual information, figures and statistical data on Swedish national issues. The overall assessment of Madell, however, was been confirmed by the interview data. No members of the European Affairs Committee (from either opposition or government parties), or of the parliamentary staff (current or former) dealing with EU issues highlighted any significant challenges to the Riksdag administration. As a former member of the European Affairs Committee secretariat (S26) stated, members of the Riksdag have enough administrative support, although "they need their own will to look into something". The level of resources used for the scrutiny of EU affairs might not have greatly increased in the aftermath of the Lisbon Treaty, but that does not mean that the means at the disposal of the European Affairs Committee or the other Riksdag committees are insufficient.

\subsection{Role of parliamentary administrators}

In principle, the fact that parliamentary administrators are crucial in providing administrative support for the scrutiny process allows them to exert a certain measure of influence on the outcome of parliamentary deliberations on EU affairs. In practice, however, such influence is restricted by a number of factors. Parliamentary administrators in Sweden tend to make a strict division between technical and political functions. Doing otherwise is considered inappropriate in the informal code of conduct of committee staff, as opposed to party staff working in the parliament. Hegeland (2015) mentions that the general principle of appointing to posts within the civil service exclusively on the basis of merit, as enshrined in the Swedish Constitution, is also applied to nominations within the Riksdag administration. A former member of the EAC secretariat (S26), who is now a member of party staff in the Riksdag, provides examples of how parliamentary administrators interact with party staff: "We have a strict culture that committee staff share everything with deputies but make a difference between members of parliament and party staff. ${ }^{151}$ If I hear about a document being sent to an MP I can call

\footnotetext{
${ }^{151}$ The respondent is referring to her current post as a party staff member.
} 
and ask for the same document, but the committee secretariat would not be proactive ${ }^{152}$. Sometimes I would need to contact an MP directly to look at the document. This pattern is the same for all parties... When committee staff makes an evaluation of a document they never collaborate with party staff; there is a strict dividing line, which is normal". A member of the Riksdag (S10) confirms the fact that interaction between parliamentary staff and party staff is kept to a minimum: "There is very limited communication between parliamentary staff and party staff; communication usually goes through parliamentarians because committee staff want to be sure that information requests come directly from an MP and not from party staff members". Members of the parliamentary administration obviously need to interact with MPs but direct contacts with party staff are avoided in order to guarantee the impartiality of parliamentary staff and avoid any ideological bias in their analysis.

The reasons for the low level of politicization ${ }^{153}$ of the European Affairs Committee staff in the Riksdag are not limited to the distinct Swedish parliamentary culture, which stresses impartiality and a strict division between technical and political tasks. The fact that the composition of the European Affairs Committee changes quite a lot from one legislative term to another, in the opinion of a former Riksdag staff member (S38), means that the 'rapport' between MPs and European Affairs Committee staff is less close than in other standing committees, where it is not unknown for an MP to be a member for two or more successive terms and therefore develop a close collaboration with committee staff.

Potentially, by pre-selecting items for scrutiny parliamentary, staff can play a crucial role in setting the agenda for the discussion on EU affairs. In practice, parliamentary staff members are reluctant to take these opportunities to gain more influence on developing the agenda. For example, the staff of the European Affairs Committee are willing to reduce the number of ' $A$ ' points ${ }^{154}$ which they need to look through and put on the agenda of committee meetings. Parliamentary staff would prefer to delegate this selection to the government, and thereby reduce their own workload. A former staff member of the EAC secretariat (S38) explained the position of parliamentary administrators: "We run through 'A' points, 10 seconds for each point. It creates a lot of work for the staff but almost never has any political effects". Staff members seem willing to trade agenda-setting opportunities for a less bureaucratic workload.

Nonetheless, parliamentary administrators play a crucial role in providing expertise on EU affairs. Parliamentary administrators (S2a, S6b) say that committee staff obtain information on EU affairs mainly through informal networks and personal channels. There is an appreciation that these channels of information are often faster and more

\footnotetext{
${ }^{152}$ The respondent means that committee staff would not take initiative in delivering information directly to party staff.

${ }^{153}$ Drawing on the definition developed by Peters and Pierre (2004), it can be argued that the politicization of parliamentary administrators would mean that their activities were not conducted on the basis of serving the general interests of a parliament, but instead focused on supporting the position of a specific political party.

${ }^{154}$ Items on the COREPER agenda that are scheduled to be 'taken into account' without debate.
} 
reliable than official bureaucratic mechanisms. The Riksdag staff, however, see no point in 'outclassing' the government in terms of levels of expertise. Parliamentary staff members are still able to provide good assessments of EU proposals using government memos as a basis. Arguably, there is a clear understanding that parliament cannot conduct scrutiny on its own, independent of the government, otherwise the flow of information and its analysis would risk becoming unmanageable. A staff member of the Riksdag's administration represents this view by arguing that "nobody has the resources to make independent analysis....You should have a common basis of facts but then make different conclusions depending on your political attitude" (S12). Even members of the parliamentary opposition share this attitude. A member of the Social Democrats (S32) pointed out that "if the clerks in the government are good, then it is also a great assistance for us".

The importance of parliamentary staff in providing expertise is strengthened by the fact that individual members of the Riksdag have only limited resources to engage in parliamentary scrutiny. Both the left wing opposition parties, as an assistant of a Swedish left-wing member of the European Parliament (MEP) (B17) testifies and the junior government coalition parties face this challenge, often having to employ part-time assistants and secretaries. Hence, MPs from the abovementioned parties try to compensate for their limited resources by increasingly relying on parliamentary administrators when conducting scrutiny.

The role of parliamentary staff in addressing administrative challenges and streamlining the scrutiny process is further emphasized by the fact that recent experience in Brussels, for example, internships with EU institutions, is considered an asset for someone attempting to get a position in the Riksdag. Moreover, the introduction of the post of 'EU coordinator' in each standing committee is likely to increase the quality of EU expertise in the Riksdag. Nonetheless, a staff member of the Riksdag (S6c) stresses that only seven of the 15 standing committees in the Swedish Parliament have such posts, and the job description does not necessarily refer to EU affairs as the main topic. Interestingly, the representative of the Riksdag in the European Parliament (B39b) considers the introduction of the post of coordinators primarily an instrument of burden-sharing within committee secretariats, which has had little direct impact on the scrutiny process. A staff member of the Riksdag (S6c) summarizes his assessment of the role of the coordinators: "The most important element is that EU affairs are also given to standing committees. Whether there is a coordinator on EU issues or not does not matter so much as long as these issues are addressed".

Occasionally, parliamentary staff come under extreme pressure to deliver analyses in a very short period of time. For example, a member of the European Affairs Committee (S9) argued that for Friday EAC meetings members of the Riksdag get their dossiers about two hours in advance, meaning that the brunt of the speedy preparation of documentation is borne by the staff of the European Affairs Committee. This procedure was introduced at the request of the Left and the Green parties, which demanded that a min- 
imum amount of time should be granted to them in order to study the dossiers and formulate opinions on specific proposals. Apparently, the work is more challenging because the parliamentary administrators directly responsible for EU affairs deal more with the EU decision-making cycle than with the proceedings of the Riksdag. Staff members argue that the busiest time for them is during the time of presidency rotation. The uneven workload throughout the year also adds to the impression that the work in the European Affairs Committee, in the words of a former staff member (S38), "is the most hectic of all Riksdag committees".

In principle, parliamentary staff in the Riksdag can shape the scrutiny process by making MPs aware of important issues on the committee's agenda, drafting resolutions on behalf of political parties and 'transposing' partisan views into draft resolutions on EU affairs. Given the fact that members of the Riksdag do not act as rapporteurs ${ }^{155}$ on specific policy proposals, it often falls to parliamentary staff to write draft reports and present summaries of committee deliberations. The former task allows parliamentary administrators to shape the scrutiny process by bringing in new information as, according to one Riksdag administrator (S6a), "staff can add views which were not explicitly stated during the current debate, for example, the earlier positions of actors on the issue under discussion". However, when tasked with presenting the final results of MPs' deliberations, staff seem to closely follow the guidelines set by the political parties. A staff member of the Riksdag (S6a) says that the format of the final resolution depends on the wishes of the politicians, adding that "most of the time the chairman says whether committee staff should write a document in order to get all political parties into something common or they can present dissenting views". Parliamentary staff in the Riksdag could gain political leverage through their provision of expertise, but they would not be involved in brokering an inter-party agreement. A staff member of the Riksdag (S6a) describes the relationship between parliamentary administrators and political parties: "The role of the staff is to provide expertise, while parties then decide on alternatives. Only if they ask the staff to find a common position do we do so".

Despite the fact that the knowledge of MPs on EU issues has increased, committee staff have an important 'signalling function' in identifying the most salient topics and ensuring that MPs are acquainted with key subjects. A member of the European Affairs Committee (S9) illustrates this idea: "The secretariat of the European Affairs Committee has an important task in saying, for example, "Here is an important piece on agriculture and if you want to survive in this committee you better look at it". Another staff member at the Riksdag (S6c) suggests that the 'signalling' function of committee secretariats can partially explain the high number of reasoned opinions passed by the Swedish Parliament. The respondent doubted whether MPs could identify such a high number of controversial issues on their own ${ }^{156}$.

\footnotetext{
${ }^{155}$ A designated MP who presents a report on a specific policy issue which is later debated in a parliamentary committee and serves as the basis for a resolution after the necessary amendments have been included.

${ }^{156}$ However the respondent stressed that he could not provide any clear policy examples.
} 
When preparing reports on domestic issues, parliamentary staff have a set of implicit guidelines that must be followed. Parliamentary administrators (S2a) described this practice: "These reports include what we think are the majority and minority opinions. Parties never disagree with the way their opinions are presented. Sometimes they add a sentence or some minor change. What we write we get from bills, newspapers and debates. We do not invent anything. In the case of minority opinions, we deduce them from private members' bills".

On the other hand, in the domain of EU affairs parliamentary staff often have no clear guidelines from political parties, so administrators in the Riksdag could have greater leeway in framing resolutions that deal with EU issues in the initial stages of committee deliberations. A member of parliamentary administration (S2a) described the situation: "When it comes to EU matters, we do not know what the party stance will be. We have to guess and listen". As another parliamentary staff member (S38) noted, "it is often almost impossible to define party positions on the EU". Thus far, this practice does not seem to have led to a mismatch between the Riksdag resolutions drawn up by parliamentary administrators and party positions, but it clearly shows that EU issues have not been fully 'internalized' by MPs and their respective political parties. A Riksdag staff member (S6b) supported this idea, noting that "on EU issues you do not have the same mechanism for negotiating where each party can go home, think about the text, etc. It is like a journey with no map "157", Arguably, the situation has not changed a lot as in late 2013, roughly 18 months after the date of their initial interviews, respondents (S2b, S6c) referred to the same lack of established guidelines from political parties on EU issues. For example, a member of the Riksdag's administration (S6c) noted that: "Parties know what to do in domestic affairs but in EU affairs they react to the news from the government". The respondent argued that Swedish political parties do not necessarily have a detailed established position on all aspects of EU policies. Instead, they rely on the government to lead the debate in EU issues and formulate their opinions in this sub-field on a case-by-case basis.

Even though, due to the lack of clear guidelines on EU affairs, parliamentary administrators could directly influence the content of specific resolutions and the related parliamentary debates, it seems that the staff of the Riksdag do not take this opportunity to push for a specific policy goal. When asked about the way parliamentary administrators deal with the lack of political guidelines on EU affairs, a staff member of the Riksdag (S2a) responded that: "If we do not know, we try to minimize what we are saying ${ }^{158}$ or make it clear to political parties that they have to tell us what to write". In general, parliamentary staff seem to be reluctant to take on a more active political role in shaping the scrutiny process. Administrators in the Riksdag can exert leverage by providing expertise for parliamentary debates or 'interpreting' partisan opinions in the initial stag-

\footnotetext{
${ }^{157}$ The metaphor was suggested by the interviewer; the respondent explicitly agreed.

${ }^{158}$ Respondents imply that they would try to draw up a rather vague text which did not explicitly force political parties to have a clear position.
} 
es of committee debates. By contrast, parliamentary staff seem to play a more limited role in guiding the subsequent debate as it is the MPs who instruct parliamentary administrators on the final version of a resolution.

\subsection{Role of parliamentary committees}

The Lisbon Treaty has reinforced the trend for devolving political powers from the European Affairs Committee to sectoral committees, potentially increasing their leverage on policymaking. This intensive involvement of sectoral committees secures access to expertise, and allows MPs to better grasp the connections between EU and national policies. The timing of meetings does not seem to be a huge problem for communication between the European Affairs Committee and other sectoral committees. Sectoral committees normally meet on Thursdays, while the European Affairs Committee meets the next morning in order to prepare for a Council meeting on the following Monday. This practice, in the opinion of a left wing opposition member of the Riksdag (S24), does not seem to compromise the quality of expertise or lead to huge delays in carrying out assessments. Nonetheless, contacts between the European Affairs Committee and the sectoral committees face a number of challenges.

First, cooperation between the EAC and the sectoral committees in the Swedish Parliament is not regulated by an extensive legal framework. The only direct reference to inter-committee cooperation is Chapter 4 of the Parliament Act, which states that any committee may provide another committee with an opportunity to deliver an opinion, or two committees may prepare a joint opinion. The 'informality' of sectoral committee involvement in the scrutiny process can encourage such interaction. On the other hand, information between committees is still exchanged much more along party lines than by means of formal reporting between parliamentary staff. The same pattern existed before the entry into force of the Lisbon Treaty. Riksdag staff members (S2a) highlight that parties and committees are "parallel systems". This opinion is supported by party staff members, parliamentary civil servants, as well as current and former members of the Riksdag ${ }^{159}$. Arguably, it is not the specific 'committee identity' that binds MPs together and enables them to establish cross-party coalitions, but party affiliation that structures communication between committees and ensures that partisan views dominate the European Affairs Committee.

Second, sectoral committees rarely issue opinions on the basis of the information provided by the European Affairs Committee (Raunio and Wiberg in Barrett 2008; Öberg and Jungar 2009), while in the EAC there is no formal procedure for handling contributions from sectoral committees. Nonetheless, both are forced to cooperate. In cases where the government's position in the Council of Ministers is discussed, sectoral committees have to deliberate with the European Affairs Committee as only the latter is endowed with formal powers to issue a mandate. For example, minutes are taken when

${ }^{159}$ According to interview data from respondents S5, S6a, S10, S24, S26, S29, S34. 
a minister is invited to a session of the European Affairs Committee, in contrast to similar meetings in sectoral committees. According to a senior Riksdag administrator (S12), this helps follow-up on the government's decisions and is one of the elements of the European Affairs Committee's coordinating powers which other committees lack. At the same time, the EAC is highly unlikely to support a document or a proposal to which a sectoral committee is vehemently opposed. A member of a sectoral committee in the Riksdag (S36) expanded on this topic: "It is important that standing committees are involved. Even now we can formally write down that we do not want to give a mandate and this would be a very strong sign for the European Affairs Committee, although it is not a mandate but strong influence. A majority against a proposal in a standing committee is in reality a no-mandate in the European Affairs Committee".

Third, according to a former head of the European Affairs Committee (S34), the staff in the standing committees sometimes show little interest in EU affairs, and it can be hard to motivate them to conduct scrutiny. It is also hard to assess how much time standing committee staff members spend on EU affairs. The figure could be 20-30 per cent of their time, but a respondent from parliamentary administration (S6a) stresses that this is a rough estimate. In fact, the staff of sectoral committees occasionally resist closer collaboration with the staff of the European Affairs Committee. According to a former staff member at the EAC (S26), "there has always been, at least since when I started working, animosity among the staff of other committees towards the EAC. People wonder what they are doing. There has not been much interaction between standing committees, they are like islands and this is a problem when you start working with European Union affairs".

On the other hand, according to the report of the EUMOT working group, MPs serving on standing committees increasingly show an understanding of EU topics. A staff member in the Riksdag (S12) stated that in practice "standing committees discuss an issue with the government and then some weeks later some people from this standing committee reiterate their position in the EAC. If nothing happens it is the standing committee that speaks on behalf of the European Affairs Committee". In such circumstances, the role of the EAC increasingly becomes coordination and monitoring, combining the agendas of various committees. The abovementioned respondent (S12) noted that: "They ${ }^{160}$ make sure nothing is forgotten, it is like a safety net". A respondent from the Alliance governing majority (S10) supports this idea, saying that if the EUMOT suggestions were taken on board the 'safety net' option of holding the discussion in the EAC would be lost. The respondent argued that, "it would be bad to give it all to sectoral committees because then EU issues would be just one more thing on which the committees need to concentrate instead of one thing that we all have to focus on".

The decentralized scrutiny system constitutes a potential risk for the European Affairs Committee. The only 'positive' power it has at its disposal is mediating and mandating, but in order to exert its influence it constantly needs to draw on the expertise

${ }^{160}$ The respondent was referring to members of the European Affairs Committee. 
of other parliamentary bodies, which might not be very willing to cooperate at the level of committee staff. For example, recent attempts to increase formal reporting between the European Affairs Committee and the sectoral committees have triggered tensions between these bodies, as both MPs (S7) and parliamentary administrators (S28) testify. A member of the European Affairs Committee from the Liberal party (S9) described the situation: "There was resistance from members of parliament and bureaucracies, secretariats of the standing committees. Now they are more used to this. They were forced to look into formal reporting on EU affairs and learn; they have started to like it and become interested".

In the opinion of a former European Affairs Committee staff member (S26), such practice can be seen as a break with the tradition of equal standing of all committees, where the EAC is just 'one among equals'. In addition, the increased demand for formal reporting does not mean that a unique protocol for handling relations between the European Affairs Committee and standing committees has been developed. Both the EAC and the standing committees have some room for manoeuvre in defining the pattern of interaction, which could trigger some bureaucratic inconsistencies. As a member of the European Affairs Committee (S9) noted: "That is up to the committees to decide ${ }^{161}$. Some say we only take a look at information and do not decide. Each committee interprets it in its own way. It forces them to seek to work through issues. They can say what they like and do not like and why".

It is also important to recall that 'service' in the European Affairs Committee is not actively sought by Swedish parliamentarians. Membership of the EAC is not thought to provide any crucial political benefits. "Members of the Riksdag do not get re-elected for this", according to a member of the European Affairs Committee (S9), no matter how high their status in the European Affairs Committee may be. EU issues are still underprioritized within the Riksdag internal hierarchy, according to a staff member of the Green Party (S5). A former staff member of the European Affairs Committee (S38) illustrates this point further by arguing that members of the EAC can be divided into three sub-groups. There are some MPs with a genuine interest in EU affairs and several 'policy experts' who monitor the discussion on their specific sub-fields in the EAC. The majority of MPs on the European Affairs Committee, however, are there, in the words of the respondent, "just to cover the seats".

\subsection{Role of political parties}

In contrast to parliamentary committees, which appear to have a limited input into the content of the scrutiny process, political parties play a more important role in the internal dynamics of the European Affairs Committee. This is illustrated by a member of the EAC (S10): "our identity as members of the party is stronger than our identity as mem-

\footnotetext{
${ }^{161}$ The respondent implies that it is up to committees to decide how to react to the demand for formal reporting.
} 
bers of the committee". In principle, the fact that, as is mentioned above, individual MPs have limited resources to conduct scrutiny of EU affairs creates the conditions for parliamentary administrators to exert greater policy leverage. In practice, however, the Riksdag's resources are concentrated in the hands of political parties, not the parliamentary administration, which allows political parties to shape the scrutiny process. A parliamentary clerk dealing with EU affairs (S6b) argued that there has been a much bigger increase $(40-50 \%)$ in the number of party staff in comparison to committee staff (an increase of $10 \%$ ) in the Swedish Parliament in the past 10 years.

Financial resources and support staff are increasingly concentrated at the level of party central offices, to the detriment of individual MPs who as a result have fewer opportunities to independently address EU topics. This assessment is shared by both parliamentary administrators (S6b) and members of the Riksdag from the Centre and the Christian-Democrat parties (S7, S8), which participate in the governing coalition. One of the parliamentary administrators in the Riksdag (S6c) described the situation regarding the resources available to individual MPs: "Now financially parties can hire one assistant for each MP but in practice most resources go to the party leader and to the top of the party hierarchy. Individual members of the Riksdag get only a limited amount". A Social Democrat member of the Riksdag (S29) argued that it is his party which is most disadvantaged by the current practice. After two consecutive electoral losses, they have fewer financial resources, which necessarily impinges on the amount of assistance they receive. The Social Democrats could have relied on increased numbers of parliamentary staff but the administration of the Riksdag has not been enlarged. Resource shortage can be just one of the factors that make it difficult for the Social Democrats to work on EU issues in the Swedish Riksdag. As a staff member of the Social Democratic Party in the Riksdag (S11) explained: "Even though parliament has the resources and the organization for all the work on subsidiarity and proportionality, Green Papers, etc., we are not able to work with these tools within the party. I think it has to do with the fact that we are an opposition party, our heads are filled with day-to-day politics, it is hard to work strategically and with a long-term perspective".

The mode of discussing EU affairs in the Riksdag is very consensual, and this has not changed in the aftermath of the Lisbon Treaty. The position of the government on EU affairs has occasionally been modified by parliament but it has rarely been rejected (Hegeland 2011; Johansson and Tallberg 2010). There have been few if any executivelegislative conflicts on EU affairs. A member of the Riksdag from the Centre Party (S7) explained the situation: "Since the government is a minority government it has to make sure that it has support before meetings begin. So it always has talks with the Social Democrats and Greens beforehand, trying to build up a wide consensus". All conflicts between the government and the parliamentary majority are decided internally and there are few attempts to make them public, according to members of the Alliance governing coalition (S9, S10). 
The logic of the European Affairs Committee's work is consensus-building (or confirming the consensus reached beforehand) because during scrutiny, there is a lot of focus on unanimity, according to a staff member of the Committee on the Constitution (S35) who has interacted a lot with the EAC. Internal tensions in the Alliance ruling coalition are growing due to the fact that the Christian-Democrats and the Centre Party have been 'overshadowed' by the largest coalition partner, the Moderate Party, as several Swedish experts argue (S17, S23). In such a situation, attempts to reach consensus among parties in the European Affairs Committee are considered even more important as otherwise the electoral chances and the ruling status of the centre-right might be compromised. According to a former member of the European Affairs Committee staff (S38), it is a strong symbol of the consensus culture prevailing in the European Affairs Committee that members of other sectoral committees who are 'posted' to the EAC to discuss specific policy proposals are more conflict-prone in their rhetoric than the 'permanent' members of the European Affairs Committee.

As is mentioned above, any attempts to increase parliamentary control over the Swedish Government by allowing the Riksdag to issue a legally binding mandate on EU affairs have been rejected. Jungar and Öberg (2004) explain this by arguing that the European Affairs Committee was initially set up as a tool to legitimize the government's positions on the EU, not as an instrument to secure accountability for its actions. This approach to the role of the EAC can only strengthen its focus on consensusbuilding. At the same time, a member of the Alliance (S10) argued that the "Swedish Parliament is one of the strongest but at the same time one of the most loyal". One potential explanation could be that in many instances, minority governments in Sweden found themselves in a situation of strong bloc voting by both right- and left-wing parliamentary parties, which allowed ruling coalitions to act as a majority government and enjoy a substantively low number of amendments to its laws (Arter 1999). In practice, the government deliberates with the opposition more on 'national' matters than on EU issues (Hegeland and Neuhold 2002). A former staff member of the EAC (S38) mentioned that it is also clearly understood that a consensual opinion from the European Affairs Committee helps negotiations in Brussels and makes Sweden stronger vis-à-vis other member states as it allows the government to present and fall back on a united national position. Even the occasional questioning of ministers is considered to be more a preparation for negotiations in Brussels than a conscious attempt to put pressure on the executive. Arguably, the focus of the scrutiny process is not on influencing the government, but preparing a united position for the Brussels arena and rigorously testing it. This idea was voiced by representatives of the governing coalition (S9, S10) and parliamentary staff members (S38). In the opinion of the latter, the European Affairs Committee can be compared to a 'wartime coalition cabinet', which focuses on developing a consensual approach. A member of the Riksdag from the Christian Democratic Party used a similar line of argument (S8): "Usually we agree with members of the Alliance in the government. It is a bit like checks and balances and this functions well. 
The government knows and understands that it is important to get parliament on board and make up broad majorities, and this is a huge back-up in Brussels. It is good that we attempt to speak with one voice vis-à-vis other EU countries".

Political parties also control the composition of the European Affairs Committee as due to the reform of 2007, any party can send a member of a standing committee to an EAC meeting in order to discuss a policy subject in which he or she is expert ${ }^{162}$. According to Hegeland (2015), a large number of substitutes ${ }^{163}$ in the EAC allows all parliamentary parties to have access to policy expertise when the work of a specific Council formation is discussed. Members of the Riksdag who are 'posted' to the European Affairs Committee are often exactly the same people who have already discussed the dossier under scrutiny in the sectoral committees. This practice means that a party opinion is consistently voiced in both standing committees and the European Affairs Committee. It also means that the political parties structure discussions which are developed in the EAC. as party opinions play a crucial role and set the pace of debate.

Despite the fact that at the time of writing the chair of the European Affairs Committee comes from the governing coalition, the composition of the committee favours the opposition. Seven members come from parties which support the government and 10 members from opposition parties. However, the opposition finds it hard to exploit this numerical advantage as it can overrule the governing coalition only if all the opposition parties - the Social Democrats, the Left Party, the Green Party and the Sweden Democrats (radical right) - can present a consolidated opinion, and this does not happen very often. According to a staff member in the Riksdag (S6a), the government's view normally predominates if there is no majority for an alternative, highlighting that differences between opposition parties often allow the government to have its own way. In practice, on many occasions the Riksdag committees, including the European Affairs Committee, simply formalize what has already been decided on the basis of inter-party negotiations and exchanges of concessions, as, for example, the Alliance parties (centreright governing coalition) continually coordinate their actions in the Riksdag. Talking about the day-to-day work in the Swedish Parliament, the representative of the Riksdag in the European Parliament (B39a) mentions that "party positions are often already known before the European Affairs meeting", although this by no means implies that members of the opposition are always complacent about the position of the governing coalition.

As is mentioned above, there has recently been more pressure to formalize contacts between the EAC and sectoral committees during the scrutiny of EU affairs. The logic behind this new measure is not only to streamline contacts between committees, but primarily to increase partisan influence over committee deliberations. A member of the

\footnotetext{
${ }^{162}$ The practice also means that when a parliamentary party has no MPs from a sectoral committee who serve as regular substitutes in the European Affairs Committee, a political party can nominate any of its own members in the Riksdag to come to an EAC meeting to share his or her expertise.

${ }^{163}$ Substitutes are members of parliament who replace MPs in committee deliberations if the latter cannot participate.
} 
European Affairs Committee from the Liberal Party (S9) argued that the key goal of the greater involvement of sectoral committees was to detect and resolve tensions between the parties at the 'lowest possible level' before they reach the European Affairs Committee.

The debate about the report of the EUMOT working group provides an interesting example. The political parties rejected the transformation of the Riksdag's rules of procedure proposed by parliamentary administrators. The key suggestion of the EUMOT report was to provide standing committees with a right to mandate the government on negotiations in the Council of Ministers. In the opinion of a parliamentary clerk (S3), this proposal was rejected because it did not fit the interests of the two largest political parties from the governing coalition and the opposition, the Moderate Party and the Social Democrats, respectively. According to the abovementioned respondent, devolution of mandating rights would have implied weaker control for the two largest parties over the EU agenda in the Riksdag. On the other hand, the smaller parties from both governing coalition and opposition could have obtained benefits from decentralization of mandating powers in the scrutiny of EU affairs. According to a member of the parliamentary administration (S6b), small parties supported a greater role for sectoral committees in line with the EUMOT suggestions as this would help them 'outsource' EU affairs scrutiny to committee staff and optimize their own resources.

The crucial role of political parties in shaping the Riksdag's rules of procedure can be further illustrated by debates about the follow-up to the EUMOT working group ${ }^{164}$. For example, according to information provided by both current and former staff members at the Riksdag (S3, S6b, S6c, S38), the Green Party and the Left Party resisted delegating the selection of 'A' points to the government and reducing the time spent on their discussion during EAC meetings, much to the chagrin of parliamentary administrators. In practice, staff members just skim through them, which takes up a lot of time with little practical result. At the same time, the Green and Left parties consider this procedure a cost-effective way of keeping them informed about EU issues. As a former parliamentary clerk (S38) noted, "these parties would object to anything that diminishes the amount of information they get". Given the fact that the Green and Left parties rely heavily on the current system of addressing ' $A$ ' points in order to obtain information and analysis of EU issues, they resist any proposals to change it. This assessment is supported by the opinion of an MP from the Left Party (S24), who argued that in contrast to the situation in 1990s (Hegeland and Mattson 2000), the current scrutiny procedure is much closer to the preferences of his party. Hence, the Green and the Left parties see little political benefit in supporting the reform of the 'A' points selection procedure. Ultimately, the debate on the follow-up to the EUMOT report shows that even if parliamentary administrators were willing to introduce changes, political parties would effectively block them.

\footnotetext{
${ }^{164}$ Although the key proposals of the EUMOT working group were rejected there was a discussion about whether some technical elements of the EUMOT recommendations could be implemented. Ultimately, a decision was made to maintain the status quo and disregard these proposals.
} 
Political parties also have a veto on selecting among the policy solutions provided by parliamentary staff. Committee staff may provide expertise but it is the MPs who decide on the various alternatives. As members of the parliamentary administration (S2a) argued, 'the committee staff never make policy suggestions, they write both majority and minority opinions'. It is noted above that political parties in the Riksdag often do not have a clear position on EU issues. In the opinion of a member of the European Affairs Committee (S9), "this lack of party opinion can also sometimes be the reason why sectoral committees have no formal negotiations. It could be difficult 165 to "mine" views". This implies that political parties can be a 'negative' agenda-setter, limiting the scope of discussion on EU topics. Moreover informal inter-party meetings, which often precede committee deliberations, are likely to limit the political leverage of parliamentary administrators as they have a few instruments in such circumstances, such as drafting resolutions and providing expertise, which would normally allow them a measure of influence.

It could be argued that MPs also use the strict division between party (political) and committee (technical) staff which exists in Riksdag to their own benefit. For example, when committee staff write an opinion from a party into a resolution on EU affairs, information on the specific party position is provided by MPs, not the party staff. In the opinion of a parliamentary administrator (S6b), this allows MPs to have a measure of independence from their respective party structures and to exert a measure of control over their assistants.

Political parties are also largely in charge of the Riksdag's contacts with the European Parliament, which are becoming more intensive according to a member of the European Parliament administration (B18). It should be noted, however, that contacts between members of the Riksdag and MEPs can be difficult. For example, according to information provided by a former staff member of the European Affairs Committee (S38), some Swedish MEPs lobbied for formalized access to EAC meetings and to plenary debates in the Riksdag, only to find these requests turned down by MPs. Existing contacts run along party lines, but the difference in work schedules and a resource gap between MPs and MEPs restricts them. A respondent who had experience in both the Swedish Parliament and the European Parliament (S24) stressed that it is complicated to combine the work schedules of both, even if the potential benefits of such cooperation are recognized. Even for opposition members, who can use contacts in the European Parliament to circumvent the government, the differences in the schedules of MEPs and MPs are considered a major problem, as a member of the Social Democratic Party staff argued (S11). It is highly symbolic that a respondent from the European Affairs Committee (S28a) mentioned that the focus of its work is the Council, not the European Parliament.

Allegedly, the added value of policy coordination between MEPs and MPs has not been fully exploited. The exceptions are arguably the Moderate Party and the Social

${ }^{165}$ For parliamentary administrators. 
Democratic Party. At the beginning of 2012, the latter opened a coordination bureau to streamline the work of Swedish Social Democrat MPs and MEPs. The extent to which these MEP-MP contacts are used strategically remains unclear, however, as cooperation is conducted on an 'issue by issue' basis. There is little demand for more institutionalized forms of cooperation.

Potentially, opposition left wing parties such as the Social Democrats can use these coordination schemes between members of the Riksdag and MEPs to compensate for their weak position vis-à-vis the government. In fact, several working groups of Swedish Social Democratic MPs and MEPs have been organized on a number of occasions $^{166}$. Moreover, policy advisers to the Social Democrats in the Riksdag have started to develop a dialogue with their colleagues in the European Parliament, according to a staff member of the Swedish Social Democrats (S11b). At the same time, MPs from the governing coalition arguably have fewer incentives to concentrate on the European Parliament agenda, as they can obtain most of the necessary information from the domestic executive. As a result, according to a member of the Centre Party (S7), "we are mainly working towards the Council".

Despite the fact that the Riksdag representative in the European Parliament is not the only link between the Swedish Parliament and the European Parliament, parliamentary officials occupying this post can play an important role in the national scrutiny of EU affairs. In practice, however, it seems that Swedish MPs almost never directly contact the Riksdag representative in the European Parliament, as both the person occupying the post (B39) as well as a member of the Riksdag (S24) confirmed. It is committee staff members and not MPs, according to a parliamentary official (S6b), who primarily use contacts with the Riksdag's representative in the European Parliament to obtain information. In fact, the Riksdag often gets much better information on activities in the Council working groups ${ }^{167}$ or the Swedish Permanent Representation than on issues developing in the European Parliament (S12). Even parliamentary administrators often prefer to get the required information from government officials and not use the opportunity to consult the European Parliament, according to a staff member at the Riksdag (S2a).

\subsection{Evaluation of Swedish parliamentary practice}

In the aftermath of the Lisbon Treaty, the structural elements of the Swedish scrutiny system - decentralization, high involvement of sectoral committees and a coordinating

\footnotetext{
${ }^{166}$ According to a member of the Riksdag from the Left Party (S25), individual MPs attempted to build up connections with MEPs from similar ideological groups in cases of ACTA (Anti-Counterfeiting Trade Agreement) and fishing agreement with Morocco. Nothing similar has been detected during the scrutiny of the Green Paper on pensions and the Proposal for a directive on seasonal migrants, although it has to be acknowledged that the thesis has not comprehensively focused on MP-MEP contacts, respondents agree that such connections are sporadic.

${ }^{167}$ Monitoring trialogues is still a problem
} 
role for the EAC - have stayed the same. In fact the Swedish Parliament has demonstrated a rather 'path-dependent' approach to addressing EU issues. As the analysis of the debates around the Green Paper on pensions and the Proposal for a directive on seasonal labour migrants have shown, parliamentary scrutiny can overlook the content (and the potential challenges) of the EU documents under discussion, concentrating instead on the division of competences and limiting potential interference of the EU in Swedish domestic affairs. The design of the Riksdag scrutiny system, however, allows the Swedish parliament to be extremely active in the Early Warning System. The Swedish parliament considers all incoming EU policy proposals, while comprehensive burden-sharing has been established between the EAC and sectoral committees. As a result, the Riksdag has passed the largest number of reasoned opinions ${ }^{168}$ in comparison to other national parliamentary chambers ${ }^{169}$.

As the analysis of the debate around the EUMOT report suggests, political parties have consciously supported the status quo and played a key role in shaping and managing the scrutiny process by prohibiting any change in the rules of procedure. Measures such as the delegation of mandating rights to sectoral committees and a reduction in the ' $A$ ' points scrutinized during the selection of EU documents have been rejected by political parties, while parliamentary administrators have not been successful in promoting their vision of the rules of procedure. The behaviour of political parties may have been driven by party size and status in government or opposition. For example, the Moderate Party and the Social Democrats, representing the largest party within the governing Alliance coalition and the largest opposition party, respectively, have resisted the devolution of mandating rights to sectoral committees. On the other hand, small parties in both the governing coalition and the opposition would have favoured such a decision. Opposition parties such as the Green Party and the Left Party also resisted any change in the rules of procedure out of fear of losing access to information on EU topics. Ultimately, all attempts to change the scrutiny system have been unsuccessful due to the veto powers of the largest parties in the Riksdag. It is noteworthy that the large number of reasoned opinions adopted by the Riksdag can be partially explained by the fact that Sweden has a minority government. The fact that Sweden has a minority government leads to a situation when political parties are forced to negotiate, what allows critical attitudes towards the EU as well as specific policy issues to come to the fore and be channelled into reasoned opinions. As a result reasoned opinions are more easily formulated and adopted.

Parliamentary administrators, on the other hand, do not seem to play a role in promoting a distinct political agenda of their own or shaping the outcomes of scrutiny according to a set of specific policy preferences. Swedish parliamentary culture prescribes

\footnotetext{
${ }^{168}$ See COM (2014) 507 final as well as European Parliament (2014) for the numbers of reasoned opinions submitted by each national parliament

${ }^{169}$ It should be noted, however, that the Riksdag is not very active in the political dialogue with the European Commission. This could be explained by the fact that within the Swedish political system the political dialogue and negotiations with EU institutions are considered to be the prerogative of the national government
} 
a strict division between technical and political tasks. Parliamentary staff could exert political leverage in the scrutiny process by providing expertise and 'transposing' partisan views on EU issues into draft resolutions. On the other hand, even when there are no clear partisan positions on EU topics and parliamentary administrators can shape draft resolutions at their own will, parliamentary staff members tend to avoid this 'steering function' by coming up with general, uncontroversial texts or asking political parties for more guidance. Moreover, it is the members of the Riksdag who give parliamentary staff instructions on how the final versions of committee resolutions on EU affairs should look.

Parliamentary committees in the Riksdag serve as fora for presenting and discussing parties' suggestions. Little in terms of a specific committee esprit de corps is developed in the European Affairs Committee of the Riksdag, which limits its distinct committee input into the scrutiny process. Moreover, even in the highly decentralized Swedish system some sectoral committees are ready to engage in EU affairs scrutiny only on an ad hoc basis. Political parties have largely pre-empted independent involvement by the EAC in the scrutiny process, by controlling nominations to committees and controlling contacts between the EAC and the sectoral committees.

In terms of assessing the reaction of Swedish parliamentary actors to the new 'opportunity structure' it can be said that the concepts of 'voice', 'threat of issue exit' and 'neglect' are thus primarily applicable to political parties. This is because even when parliamentary administrators adopt a more active political role, their actions are still subject to 'compliance control' from political parties.

Committees act more like an arena for formalizing inter-party agreements, which are often reached outside committee settings. In other words, political parties seem to be the dominant parliamentary actor in the scrutiny process. Given the fact that the functioning of the European Affairs Committee in the Riksdag is geared towards reaching consensus while involvement of sectoral committees is used to detect any potential inter-party conflicts and resolve them at an early stage, it can be said that the key reaction of parliamentary parties to the new opportunity structure is 'voice'. Parties from both the governing coalition and the opposition engage in informal negotiations and attempt to secure a broad consensus behind their proposals.

The 'threat of issue exit' has not been widely used by Swedish parliamentary actors. Although the opposition Social Democratic Party has started coordinating with Swedish left wing MEPs, so far this process seems be more to do with ad hoc information exchange than a coherent strategy to put pressure on the Swedish governing coalition. In the process of scrutinizing the Green Paper on pensions and the Proposal for a directive on seasonal migrants, no parliamentary actor from the Riksdag attempted to establish contacts with the EU institutions or stakeholders in order to exert pressure on the government and make it change its policy course.

No references have been found to any attempts by the Riksdag to develop coalitions with other national parliaments in order to promote its views on the EU proposals 
on pension and labour migration ${ }^{170}$. The Swedish Parliament made no attempts to contact the rapporteur (European People's Party, EPP) on the Green Paper on pensions, according to an assistant to the rapporteur in question (B19). Nor were contacts established with shadow rapporteurs from the Progressive Alliance of Socialists and Democrats in the European Parliament (S \& D) (B20) ${ }^{171}$ and the Greens (B21) ${ }^{172}$. Similarly, the Proposal for a directive on seasonal labour migrants did not prompt the Swedish MPs to contact the European Parliament rapporteurs and shadow rapporteurs from various party groups (B22, B23, B24, B25, B15). No attempts were made to establish direct contacts between the Riksdag and Brussels-based organizations such as the European Trade Union Confederation (ETUC) or the European Commission, according to representatives of ETUC (B14, B26) as well as staff members in various Commission DGs (B9-11, B13). Clearly, neither the parliamentary majority nor the opposition attempted to develop these EU-level ties in order to influence the scrutiny process.

In fact, it is worth recalling that the Riksdag's initial assessment of the 'Barroso initiative', which sets the framework for a political dialogue between the European Commission and national parliaments, was quite sceptical. The Swedish contribution to the COSAC sixth bi-annual report stated that the initiative would result in the duplication of documents received from EU institutions (COSAC 2006). It should be stressed, however, that the fact that the Riksdag has not used the 'threat of issue exit' does not mean that it pays no attention to EU affairs. In practice (as stressed above) the Riksdag is one of the parliaments that resorts to the Early Warning System very actively. For example, Hegeland (2015) stresses that, according to the European Commission, in 2011 and 2012 the Riksdag submitted the largest number of reasoned opinions of any national chamber ${ }^{173}$. This implies that the Riksdag is clearly interested and active in the field of EU affairs.

The only sign of 'neglect', a certain disregard of EU issues that can be discerned in the behaviour of Swedish political parties is that the Riksdag often pays little attention to the actual content of EU proposals and focuses instead on the division of competences. It could be argued that the impact of the Lisbon Treaty on the scrutiny of EU affairs cannot be limited to the introduction of subsidiarity checks through the Early Warning System and greater access to information. The transposition of the Lisbon Treaty provisions should make MPs aware of the interconnections between domestic and EU affairs

\footnotetext{
${ }^{170}$ It should however be stressed that according to one respondent (S7) the Riksdag cooperated with the Czech and Polish parliaments on ACTA (Anti-Counterfeiting Trade Agreement). As this policy issue is not exclusively linked to the EU agenda and deals with an international trade regime, this aspect was not further researched for this dissertation. It is acknowledged that more systematic research on the inter-parliamentary activities of the Riksdag and its contacts with EU-level institutions is needed.

${ }^{171}$ There were contacts between the S\&D rapporteur and the Belgian Parliament, but these were based primarily on the previously established social network of the rapporteur.

${ }^{172}$ No responses were received from European United Left-Nordic Green Left (GUE/NGL), Alliance of Liberals and Democrats for Europe (ALDE) and the European Conservatives and Reformists (ECR) shadow rapporteurs.

${ }^{173}$ See COM (2012) 375 final and COM (2013) 565 final for the numbers of reasoned opinions.
} 
and raise the profile of EU affairs in the internal hierarchy of national parliaments. In the Riksdag, however, specialization in EU affairs and service on the European Affairs Committee are still not considered beneficial to re-election prospects. The electoral and policy benefits that parliamentary parties can gain from comprehensive assessment of the content of EU proposals are not exploited by the political parties.

The focus on the division of competences and neglect of proposals' content could reflect the challenges which the Riksdag faces in addressing EU affairs. Öberg and Jungar (2009), for example, argue that Swedish MPs perceive their impact on national policy towards the EU to be far less prominent than the influence of the cabinet or the Ministry of Foreign Affairs. A similar opinion was voiced by a former staff member of one of the Alliance coalition parties (S40): the Swedish national parliament is not the body that decides on EU policies, it is the office of the Prime Minister". As is noted above, the logic of creating the European Affairs Committee primarily addressed the need to develop and legitimize a joint national position on negotiations at the EU level. In this situation, the details and content of EU policies were more in the hands of the government than the Riksdag. At the same time, the strong emphasis on consensus among political parties limits any 'spillover' of inter-party conflict into the EU policy domain. Political parties control the scrutiny system in such a way that any burgeoning conflict is quickly detected and resolved. Ultimately, the scrutiny of EU affairs in the Riksdag can be considered a 'party game', not a 'committee game', as decision-making, exchange of information and coordination of action take place through partisan channels. 


\section{CHAPTER 6: Parliamentary scrutiny of EU affairs in the Czech Parliament}

This chapter considers how the Czech Parliament has used the provisions of the Lisbon Treaty to strengthen its role in the process of scrutinizing EU affairs. It is demonstrated that although the changes in its rules of procedure provided the Czech Parliament with 'mandating rights', the core of the scrutiny system remained unchanged. The chapter argues that one of the key factors in shaping the scrutiny process in the Czech Parliament is the dominance of different majority political parties in the Chamber of Deputies and the Senate, which increases the level of conflict in Czech parliamentary politics. It is shown that Czech political parties play a crucial role in managing the scrutiny process, and that they have attempted to politicize parliamentary administrators ${ }^{174}$ by trying to bring them under partisan control.

\subsection{Evaluation of EU proposals on pensions and labour migration policies in the Czech Parliament ${ }^{175}$}

The Czech Senate deliberated on the Green Paper on pensions in July to November 2010. The European Affairs Committee (EAC) of the upper chamber stressed that fundamental principles of social security as well as the adequate level of pensions should be defined by EU member states. The opinion issued by the EAC did not explicitly state that the Green Paper violated the subsidiarity principle, but it did stress the need to comply with subsidiarity. The main concern of the committee was whether the deficit in the Czech pension budget would be taken into consideration when determining compliance by the Czech Republic with the criteria in the Stability and Growth Pact ${ }^{176}$. In the opinion of the European Affairs Committee the role of the European Commission (and implicitly of the EU) in the sphere of pensions should be restricted to information exchange $^{177}$. A resolution was adopted in the Senate plenary on 3 November. It was al-

\footnotetext{
${ }^{174}$ See Chapter 5 for a definition of the 'politicization of parliamentary bureaucrats'.

175 The section first considers how the assessment of the Green Paper on pensions and the Proposal for a directive on seasonal labour migrants was conducted in the upper chamber, continuing with the analysis of deliberations over these policy proposals in the Chamber of Deputies.

${ }^{176}$ Czech pension system reform could trigger a temporary rise in the pension budget deficit due to the socalled 'double payment problem', which means that a transition from public to private pension systems may result in a temporary shortage of pension funds given the fact that money has to be used for two contradictory goals. On the one hand, it is used to pay the current generation of pensioners. On the other hand, money has to be saved to provide pension benefits within several decades to participants in private pension schemes. As a result, public authorities may need to borrow money to cover the expense of pension system reform.

${ }^{177}$ Senate of the Czech Republic. 312th resolution of the Committee on EU affairs. 6.10.2010
} 
most identical to the resolution proposed by the Senate's European Affairs Committee ${ }^{178}$. No other sectoral committees were involved in the scrutiny process.

According to a former member of the Senate administration (C10), the assigned rapporteur from the Social Democrat Party (ČSSD) was leaving for another committee and did not take much interest in the dossier, so there was no pressure to look into the detail of the proposal. It also took some time to receive the government's memorandum as it was a joint product of several Czech ministries, which ultimately delayed the Senate's assessment. It is noteworthy that during committee debates Ludek Sefzig, the Chair of the Senate European Affairs Committee, stressed the danger of 'creeping competence' of the European Union in the sphere of social policy ${ }^{179}$. A particular reference was made to the Proposal for a directive on seasonal labour migrants, which, in the opinion of the Czech senators, could potentially increase the amount of social benefits available to migrant workers.

It is interesting to note that although the memo prepared by the EU Unit ${ }^{180}$ of the Senate Chancellery referred to CJEU case C-343/08 ${ }^{181}$, this issue did not feature much in the committee's discussions. In fact, according to a former staff member at the Senate (C10), the government and the parliament were informed by the 'Czech representative in the CJEU, ${ }^{182}$ about the potential consequences of non-compliance, which ultimately led to the CJEU ruling, but this information did not trigger much activity in the parliamentary committee. The memo prepared by the EU Unit also highlighted the fact that the national debate on pension system reform was far from over and raised the question of the viability of introducing a 'second pillar' to the pension system. These ideas were presented by the Senate staff to the European Affairs Committee of the upper chamber but they were not discussed further in the committee session, the debate concentrating instead on the division of competences between the EU and the Czech Republic. As a staff member of the EU Unit noted, "in the case of the Green Paper on pensions the focus of discussion was the issue of competences, not content" (C39). According to a former staff member of the Senate's EAC secretariat (C20), "the Green Paper on pensions was a paradoxical union of the Civic Democratic Party (ODS) and the Social Democratic party (ČSSD)", although these parties have different preferences in relation to pension system design. There were also hardly any arguments with the executive on this specific EU proposal, as the government memo also highlighted potential subsidiarity concerns ${ }^{183}$. The Green Paper was discussed at a time when the new Social Demo-

\footnotetext{
${ }^{178}$ Senate of the Czech Republic. 590th resolution of the Senate. 3.11.2010

${ }^{179}$ Minutes of the Senate plenary session, $3^{\text {rd }}$ November 2010; Accessible via http://www.senat.cz/xqw/xervlet/pssenat/hlasovani?action=steno\&O=7\&IS=4419\&D=03.11.2010\#b10806

${ }^{180}$ A body within the Czech Senate administration responsible for providing expertise and technical advice on EU issues.

${ }^{181}$ For details about CJEU ruling C-343/08 see Chapter 4.

${ }^{182}$ This is the term used by the respondent during the interview. It refers to the judge nominated to the CJEU by the Czech Republic.

${ }^{183}$ Information note on the Green Paper on pensions. 27.10.2010. K 123/07
} 
crat majority in the Senate was not yet fully in command of parliamentary routine, so the ODS, which in contrast to the Czech Social Democrats, exhibits strong Eurosceptic views, was able to dominate the debate (C19). The intention was to stress that the EU has no powers to interfere in national pension policies, even though the content of the EU proposal largely corresponded with the Czech pension reform, which promoted increased reliance on private pension funds.

The White Paper on pensions was debated in the EAC as well as in the Committee on Health and Social Policy in the first half of 2012. The Committee on Health and Social Policy passed a resolution on 16 May 2012, which acknowledged the need for pension reform but stressed that member states should be responsible for the design of national pension systems ${ }^{184}$. Normally, resolutions of the EAC have to be adopted at a plenary session to acquire full legal strength, butt in the case of the White Paper on pensions this was not done due to inter-party disagreements. The document on the White Paper, prepared by a rapporteur in the EAC from the Civic Democratic Party, directly mentioned that the goals of the document were in line with the Czech pension reform. The Social Democrats found this reference unacceptable and it was dropped, as the party was against the reform of the pension system currently being conducted by the government. As a result, the resolution of the EAC included only those elements on which all the parliamentary groups could agree, such as enhancing the mobility of pension rights. It was decided not to take the resolution to the plenary in order to avoid further controversy, so the discussion stopped there. A parliamentary clerk (C39) stressed the influence of the inter-party debate on the scrutiny of the White Paper: "If the rapporteur ${ }^{185}$ wanted to include something, with the explicit support of the government, it would be dropped by a vote in the plenary controlled by Social Democrats". In contrast to the Green Paper, the EU Unit did not make a detailed study of the White Paper on pensions.

The Czech Senate EAC debated the Proposal for a directive on seasonal labour migrants on 21 September 2010. The committee's chair, Ludek Sefzig, acted as rapporteur $^{186}$. The EAC suggested that enhanced EU regulation in the domain of labour migration was unnecessary ${ }^{187}$, and stated that the proposal violated the subsidiarity principle. The committee delivered a reasoned opinion on the subsidiarity breach in compliance with Protocol 2 of the Lisbon Treaty. No other standing committees were consulted.

A staff member in the EU Unit responsible for the dossier (C27) argued that parliamentary staff were sceptical about the added value of the document: "When the Proposal for a directive on seasonal labour migrants came to us we did not see any reason

\footnotetext{
${ }^{184}$ Resolution of the Committee on Health and Social Policy № 71, 16.05.2012

${ }^{185}$ The rapporteur was from the Civic Democratic Party, a member of the governing coalition.

${ }^{186}$ Senate of the Czech Republic, $307^{\text {th }}$ Resolution of the Committee on EU affairs. 21.09.2010.

${ }^{187}$ The text of the reasoned opinion argued that "the conditions of entry and residence of third country nationals for the purposes of seasonal employment can be adequately regulated at the national level, while legal regulation at the EU level is neither necessary nor does it present an added value compared to the current state, with regard to its extent and impacts".
} 
for an EU wide framework on this issue. We were aware of the fact that the needs of individual states are very different". One of the key concerns of the Czech senators was the fact that the proposal did not have any effective mechanism to stop third-country nationals from applying to other member states after they were unsuccessful in their initial residence and work permit applications. According to the Czech Senate, concentrating on defining rules for circular migration in a limited number of sectors (agriculture, horticulture, tourism) was the wrong strategy, as the need for seasonal migrants could arise in other sectors, such as construction. The senators also claimed that it would be impossible to precisely identify the financial impact of the guarantees that should be given to seasonal workers in the area of social welfare. Contrary to the arguments presented in the Proposal for a directive, the Czech Senate claimed that establishing a common EU application system and developing new regulations would increase the administrative costs of processing entry and work permit requests. The Senate was also of the opinion that application of article 16 of the Proposal for a directive could lead to higher levels of protection for third-country seasonal migrants in comparison to national workers ${ }^{188}$. Members of the EU Unit in charge of preparing the background note were also able to consult government officials on the seasonal migrants issue, who were sceptical of the EU proposal. On 22 September 2010, the Senate adopted in plenary the version of the resolution proposed by the European Affairs Committee and sent its reasoned opinion on the subsidiarity breach to the European Commission.

Ultimately, in contrast to the discussion on the Green Paper, the assessment of the Proposal for a directive on seasonal labour migrants did address the content of the document, but senators were not comparing the content of the EU proposal to the provisions of Czech labour migration policy in order to come up with better domestic regulation. Arguably, the division of competences between the EU and national governments was still the key point of concern. Debates in the lower chamber of the Czech Parliament followed a similar pattern.

The Green Paper on pensions was submitted to the Chamber of Deputies of the Czech Parliament in July 2010, and a resolution was passed in September the same year $^{189}$. The European Affairs Committee in the Chamber of Deputies has the right to speak for the whole house and puts its resolutions on the agenda of the plenary only if it sees merit in further discussion. Ultimately, no plenary debate on the Green Paper on pensions was held. The lower chamber was somewhat less critical of the content of the EU's proposal than the Senate. The development of the Directive on Institutions for Occupational Retirement Provision (IORP) ${ }^{190}$ was considered an achievement, but reference was made to CJEU ruling C-343/08 which would put pressure on the Czech pension system. The discussion of the Green Paper in the EAC of the lower chamber

\footnotetext{
${ }^{188}$ The EU Unit staff had similar concerns about the Stockholm programme

${ }^{189}$ Chamber of Deputies, Parliament of the Czech Republic. $35^{\text {th }}$ Resolution, Committee of the European Affairs. 25.11.2010

${ }^{190}$ See Chapter 4 for more information about the content of the IORP directive.
} 
was consensual, according to the representative of the Czech Chamber of Deputies in the European Parliament (B6b), although government and opposition hold different opinions about the direction of pension system reform. A number of external experts were involved in the Chamber's European Affairs Committee hearings: representative of the Czech-Moravian Confederation of Trade Unions (CMKOS), Professor Jaroslaw Bostatek, an adamant critic of the current pension system reform, and the key expert behind the ongoing pension reform, Vladimir Bezdek. A staff member of the lower house $(\mathrm{C} 16 \mathrm{a})$ mentioned that the opinion of the European Affairs Committee was forwarded to the Committee on social policy for information purposes only after the official resolution was passed. Hence the Committee on social policy could not influence the content of the resolution passed in the lower house. The Committee on social policy passed its own resolution in January 2011, giving a positive evaluation to the Green Paper, mentioning CJEU case C-343/08 and claiming that the Green Paper on pensions did not contradict the subsidiarity principle.

Case C-343/08 could have been a perfect opportunity for the Eurosceptic Civic Democratic Party (ODS) to criticize the EU for attempting to impinge on the sovereignty of the Czech Republic, but this was not done in any of the parliamentary chambers. Apparently, this was not done because the content of the Green Paper was largely in line with pension policy priorities of the Civic Democratic Party, which wants to diminish reliance on public pensions and increase the share of private pension schemes. Staff members in both the Senate and the Chamber of Deputies could see the challenges that the Green Paper might pose to the Czech pension system and attempted to connect EU policy proposals to the wider national debate on pension system reform, but these ideas were not discussed further by MPs.

According to respondents from the lower parliamentary chamber (C16b, C31b) the White Paper on pensions received only a brief discussion. There was no vote on the final text of the resolution as the document was not considered salient enough for continued deliberation. The White Paper was considered largely to repeat the content of the Green Paper, and seemed less controversial. Hence, the Chamber of Deputies did not see the merit of investing more time on its scrutiny.

The Chamber of Deputies started the scrutiny process of the Proposal for a directive on seasonal labour migrants in July 2010. It adopted a resolution in October 2010, which raised similar objections about the directive as the Senate had already done, and considered it a breach of the subsidiarity principle. The lower chamber claimed that increased EU action in this domain would not bring any added value ${ }^{191}$, as the subject could be tackled by existing national Czech legislation while additional EU legislation would only create an unnecessary bureaucratic burden. The Chamber of Deputies expressed its opinion that the conditions and requirements for seasonal labour in the member states are so different that harmonizing them under the auspices of the

${ }^{191}$ Chamber of Deputies of the Czech Republic. Resolution of the Committee of European Affairs. $20^{\text {th }}$ resolution. 7 October 2010 
European Commission would not provide any added value. The European Affairs Committee did not cooperate with other standing committees during the scrutiny process of the Proposal for a directive on seasonal labour migrants. The opinion of the government representative, who also assumed that further EU regulation in the domain was unnecessary and agreed with notifying a subsidiarity breach, was added to the parliamentary resolution. The government stressed that the obligation to provide equal treatment for seasonal migrants in relation to EU citizens in the domain of social security (according to article 16 of the proposal for a directive on seasonal migrants) was nothing less than an intervention in national social security systems. The proposal for a directive was put on the agenda of the plenary but the debate was very short, given that the Chamber was considering the document at the very end of the eight-week timeframe for submitting subsidiarity checks and therefore had little time left. Following the same line of reasoning, another respondent from the administration of the lower house (C31) mentioned that "the reasoned opinion on seasonal migrants was very short, more an "opinion" than a "reasoned opinion", implying that there was no political will in the Chamber of Deputies to comprehensively deliberate on the issue and come up with an in-depth assessment.

\subsection{Domestic rules of procedure, material and temporal constraints}

The rules of procedure in both chambers of the Czech Parliament were adapted to incorporate the provisions of the Lisbon Treaty ${ }^{192}$. The new rules, however, did not alter the fact that in the Chamber of Deputies the European Affairs Committee can issue a resolution on behalf of the lower parliamentary chamber, while in the Senate resolutions of the EAC have to be confirmed by the plenary. In addition, during the ratification of the Lisbon Treaty, a bargain was struck between the government and a group of MPs from the Civic Democratic Party to increase the powers of the parliament ${ }^{193}$. Ultimately, in return for supporting the ratification of the Lisbon Treaty, the Czech Parliament acquired the right to issue a mandate ${ }^{194}$ on the national government when it is engaged in negotiations over a change in the decision-making rules at the EU level, such as the use of 'enhanced cooperation', the 'passerelle clause' or the 'flexibility clause ${ }^{195}$. Both parliamentary chambers were given the right to issue a mandate. It is worthwhile noting

\footnotetext{
192 Act of 6 May 2009 162/2009 ...amending the Rules of procedure of the Chamber of Deputies and Act $107 / 1999$, on the Standing rules of the Senate, as amended

${ }^{193}$ Arguably, the introduction of new competences cannot be considered an exclusive initiative of the Civic Democrats. A former member of the EU Unit (C6) states: "Yet this cannot really be treated as a party initiative. I think the proposal came from the EAC or the Constitutional Committee. It is a sensible proposal in any case let's have simplified treaty revision provision but keep us informed"

${ }^{194}$ Mandating powers mean that parliament controls or defines in one way or another the scope of the government's action during the negotiation process in the Council of Ministers

${ }^{195}$ The Czech Parliament can issue a mandate in cases where the government is engaged in negotiations on the basis of articles 31/3, 48/6 TEU and 153/2, 192/2, 312/1, 333/1,2, 352 TFEU.
} 
that the Czech Constitutional Court in its 'second Lisbon ruling' has stressed that the specific form of parliamentary scrutiny of EU affairs is a political decision, and thus it is not within the Court's competence to decide which type of scrutiny is most appropriate (Kral and Bartovic 2010, p.37).

According to Suchman (in Iglesias and Blanco 2010, p.152) these innovations do not amount to a comprehensive mandate but are better seen as a 'compensation clause', given the fact that parliament is still not able to define the content of the mandate ${ }^{196}$. A staff member of the Senate (C8b) gives the following account of the debate about the Czech Parliament's 'mandating powers': "I would not call it mandating power, it is just a need for the government to obtain prior approval for its position. It may mean that parliament can influence the position of the government, but most of these powers are framed in such a way that parliament gives consent to voting in the Council, but parliament cannot enforce any changes". This implies that the formal resolutions of the Czech Parliament will only refer to consent to or rejection of the government's position, but will not propose an alternative text for the government's negotiation position. However, this does not mean that parliament will not try to influence the position of the government before the formal negotiations between the Czech executive and legislative begin.

It should be pointed out that when the flexibility clause (article 352 TFEU) ${ }^{197}$ is under consideration, the Czech Parliament can issue a mandate to the national government only when the envisaged new EU competences are not crucial to the functioning of the Internal Market. In cases where the matter is considered 'crucial' the government can take action without obtaining a mandate from the Czech Parliament. The definition of what constitutes a 'crucial element' of the Internal Market triggers constant debate between the executive and the legislature. As a clerk in the Senate (C36) argues, "there is no legal definition what a 'crucial element of the Internal Market' is. So it is up to interpretation by officials whether the proposal has something to do with it". Parliamentary staff members are determined to engage in negotiations with the government in each and every case that potentially qualifies for a mandate, although according to a staff member at the Senate (C36) "none of these cases have been politically problematic; they usually regulate marginal aspects of the EU, so there is little interest in them, politically speaking". According to a staff member at the Parliamentary Institute (C16a), the main intention of the parliamentary administration in these negotiations is to get the government accustomed to collaborating on EU affairs: "We try to press on the government to always come and negotiate with us if there is any doubt about whether a

\footnotetext{
${ }^{196}$ The Senate resolution on the Proposal for a Council framework decision on the use of the Passenger name record (PNR) can serve as an example. The Senate recommended that the government issue a negative opinion if the documents was adopted with the wording of the Commission, without specifying what change in wording was necessary.

${ }^{197}$ The article defines how and when the EU decision-making rules can be adjusted in order to meet the objectives of the EU as laid down in the Treaties.
} 
mandate can be given or not. We prefer to take everything in all cases ${ }^{198}$ as it is a precedent for the future. We set the conditions now. If we say it is not necessary, if we do not come with a request for prior consent, then in two or three years' time the government will wonder why parliament should be involved at all".

Negotiations on whether a proposal touches on a 'crucial element' of the Internal Market are usually resolved at staff level. There have been a few occasions when a chair of the EAC or other MPs needed to be involved in order to clarify the situation. By 2013 the debate about the 'mandating powers' of the Czech Parliament had not developed into a major topic in executive-legislative relations. Apparently neither the government nor parliament wanted to politicize the issue. As a respondent from the administration of the lower chamber $(\mathrm{C} 31 \mathrm{~b})$ noted, "the discussion about the new 'mandating powers' stays at the level of the debate over competences between the government and the parliamentary chambers. The debate has not had further consequences than 'talking to each other". A staff member at the Parliamentary Institute $(\mathrm{C} 16 \mathrm{~b})$ provides his own vision of executive-legislative cooperation in EU matters: "They ${ }^{199}$ are accommodating the opinion of parliament when negotiating at the EU level but this is not always the case. Nobody is really controlling the government like coming to the responsible ministries and saying "This document and this proposal - why did you vote against it or why did you vote for it in the Council?" But basically when representatives of the government come to the committee they respect its opinion". The reason could be that despite occasional disagreements the staff of both government and parliament have built up a mutual trust and developed a 'culture of cooperation' that allows compromise. It should be noted, however, that there have been several occasions when government representatives have informally argued that a judgment on the compliance of an EU proposal with the principle of subsidiarity is a political, not a legal question, and hence it is the government that should provide guidance on what constitutes a breach of the subsidiarity principle and what does not. In general, these conflicts were related to the scope and definition of mandating rights - as well as parliamentary competences in general. They seem to have been resolved at the technical level and are used by both parliament and government to establish and secure a greater 'room for manoeuvre' for the respective institutions.

Despite the fact that according to article $10 \mathrm{~b}$ of the Czech Constitution ${ }^{200}$, it is legally possible to create a joint European Affairs Committee for the Czech Parliament, this option seems all but forgotten, as the conflicting party majorities in both parliamentary chambers in the aftermath of the 2010 general election made such a decision almost impossible. The idea of creating a joint EAC was discussed for the last time in any detail in 2004-2005, but was dropped due to strong opposition from the lower chamber.

\footnotetext{
${ }^{198}$ The respondent means that parliamentary staff always argue that the Czech Parliament has the right to issue a mandate.

${ }^{199}$ The respondent is referring to civil servants in the government.

${ }^{200}$ Article $10 \mathrm{~b}$ also states that the government is obliged to provide information to parliament on issues which arise from membership of an international organization or institution, including the EU
} 
There were, however, several common sessions of both EACs from upper and lower chambers in the aftermath of the 2012 elections to the Senate. These should not be seen as an attempt to develop institutionalized cooperation between the two bodies, but just as an 'experience sharing' event, as the new chair of the Senate EAC wanted to obtain some technical advice from the lower chamber. "After he ${ }^{201}$ got the position the Senate EAC had some joint meetings and sessions with the Chamber of Deputies in order to understand how the whole process of scrutiny has evolved", according to a staff member at the Parliamentary Institute (C16b).

Each chamber has a somewhat different legal standing vis-à-vis the government, although this does not seem to make any practical difference to the scrutiny of EU affairs. A former staff member at the Czech Parliament (C6) argues that "the Senate can pretty much look at everything that the Chamber of Deputies can look at, while the Chamber in principle can deal with more issues as its European Affairs Committee does not need to go to the plenary to approve things". Nonetheless, some differences persist. For example, when the Senate invites a member of the government to deliberate on EU issues, a minister can send a representative but is not obliged to be present him/herself, which would be the case for the lower chamber, as the government is formally accountable only to the Chamber of Deputies. The differences in the formal provisions on EU scrutiny reflect the weak bicameralism of the Czech political system (Kopecký 2007). In addition, the Senate's rules of procedure have no provision that stipulates that its views must be taken into account by the government, as during the set-up of the upper chamber's rules of procedure the government was extremely sceptical about allowing the Senate to play an active role in Czech politics (Pitrová and Coxová in Tans et al., 2007, p.211). According to Knutelska (2011), conflicts between the Chamber of Deputies and the Senate over the respective scope of competences have slowed the development of a legal framework on EU affairs scrutiny more than the lukewarm resistance of the government. Assessing the set-up of the scrutiny process in the Czech Republic, a former staff member at the Senate (C6) notes: "My view is that it was not that the government wanted one thing and parliament another but more that the upper and the lower chambers wanted different things".

The government's memorandum is still a prerequisite for the launch of the scrutiny process in the Czech Parliament. A former member of the EU Unit (C7b) mentions that the normal pattern for scrutinizing any EU proposal is first to consider its legislative aspects (legal framework, reference to specific aspects of EU law), then to assess the position of the Czech government as the second source of information, moving on to the network of stakeholders to collect additional insights if necessary. In the case of legislative proposals, a memo is prepared automatically, but for other types of EU document only on request from the parliament. Delays in delivery still occur, especially in case of non-legislative documents - occasionally up to two months. These vary from ministry to

\footnotetext{
${ }^{201}$ The respondent is referring to the new chair of the Senate European Affairs Committee, who is not affiliated to a political party.
} 
ministry, but it seems that any initial lack of information is addressed through informal contacts between the staff of the executive and legislative branches. A respondent from the Senate's administration $(\mathrm{C} 8 \mathrm{~b})$ explains the situation with the delivery of government memos in the following terms: "This is not a systematic problem ${ }^{202}$, this is a problem of individual documents and individual ministries. It is not the main factor that slows down the scrutiny process". Delays in the delivery of documents, according to parliamentary staff members (C8b, C36), are caused primarily by a lack of inter-ministerial coordination or conflicts within the governing coalition, which postpone the development of a joint position of the executive and affect the submission of government memoranda to parliament. In contrast to delivery times, according to a staff member in the EU Unit (C2), the quality of government memos does not seem to be a problem in the scrutiny process.

The Czech Parliament recently considered the option of starting the scrutiny process without waiting for a government memo, after one particular memorandum failed to be delivered for three months. According to a staff member in the EU Unit (C39), the initiative was put forward by senators from the Social Democratic Party (ČSSD), and a member of the EAC secretariat in the Senate tried to come up with practical measures to implement their request. The fact that the measure was initiated by the ČSSD, the main opposition party, could imply that the motive was to make the Czech Parliament more independent of the government, as the Senate's assessment would not be framed by a government memo and it would have to conduct a more independent analysis. These deliberations, however, have not delivered any tangible results and the practice of postponing scrutiny until a government memo is available continues. A staff member at the Senate (C36) argues that it would not have made sense to start 'independent scrutiny', as this would diminish control over the government and stretch parliament's resources. The abovementioned respondent argued that: "The added value of debating EU files without the government's position is very limited. It would actually reduce the power of parliament as it would not be able to control the position of the government in the Council. If you scrutinize the proposal without knowing what the government would say, you cannot tell the government to do otherwise if you are not in line with their position....If it is a politically sensitive issue we usually get an opinion before the official deadline, so starting scrutiny on our own would not speed up the process of passing reasoned opinions". Another staff member at the Senate (C39) continues this line of argument: "The problem is that without the mandate for negotiation from the government we cannot assess the impact of the proposal on Czech policy. This is the reason why it was dropped". The same respondent also mentioned that the new initiative would require a change in the rules of procedure of both chambers, which would create a lot of confusion and be best be avoided. Ultimately, the abovementioned debate illustrates the fact that although initiation of the scrutiny process by parliament could have helped the

${ }^{202}$ The respondent is referring to the late delivery of some memos. 
opposition set the framework for debate on EU issues, technically the Czech Parliament does not have the capacity to conduct scrutiny without the government's assistance.

According to academic experts $(\mathrm{C} 3)^{203}$ as well as staff members in the Czech Parliament $\left(\mathrm{C}^{204}\right)$, the scrutiny process is not regularly used to exert parliamentary control over the government. For example, in practice the 'scrutiny reserve" ${ }^{205}$ procedure (according to article $109 \mathrm{~b}$ of the rules of procedure in the lower chamber) ${ }^{206}$ is used not to prevent the government from taking a position in the Council but to ensure that its position is established by means of consensus. The compliance of EU proposals with the subsidiarity principle is arguably the main concern of the scrutiny procedure. In the case of the Chamber of Deputies, every resolution on EU affairs adopted is accompanied by an assessment of an EU document's compliance with the principle of subsidiarity (Szalay 2005, p.154). In the Senate, most of the documents selected for scrutiny are also checked for compliance with the subsidiarity principle. It is worth recalling that the reticence of the Chamber of Deputies in formally allowing the involvement of the Senate in the scrutiny of EU affairs shows that development of the scrutiny procedure was not perceived as a method to increase parliamentary input into formulating national policy towards the EU, but as a potential source of conflict between parliamentary chambers.

Despite the abovementioned occasional controversies between the Chamber of Deputies and the Senate, acquiring information does not seem to be a major problem for the Czech Parliament. Staff enjoy direct access to the governmental ISAP and DAP databases as well as EU Extranet, and make good use of social networks in the executive structures. At the staff level, executive-legislative relations are highly collaborative, according to a staff member at the Parliamentary Institute (C16a). The respondent noted that: "the most appreciated thing is that we do not have to wait, we can just pick up the phone, it makes our lives easier". Informal contacts between parliamentary and government staff provide information and establish a common understanding of EU issues before they are discussed at the political level. Some experts (S3) support this view, arguing that " $\mathrm{it}^{207}$ is not the government versus parliament; it is more a dialogue as they

\footnotetext{
${ }^{203}$ The respondent says: "The Czech Senate is relatively weak, it does not change government position every day but it is perceived as an important actor, the best a parliament can achieve"

${ }^{204}$ The respondent says: "There were cases when the Chamber of Deputies assessed a document and said that the government position was fine, then the Senate would reach a different conclusion, the government objected and asked the Chamber to deliberate again. The Chamber reached the same conclusion it initially had"

${ }^{205}$ In principle the procedure obliges the government to refrain from concluding negotiations in the Council until the respective national parliament has fully scrutinized the proposal discussed in the Council and formed an opinion about it.

${ }^{206}$ The rules of procedure of the Chamber of Deputies do not specify the length of the scrutiny reserve. In the Senate's rules of procedure the length of the scrutiny reserve is set at 35 days; beyond that timeframe the government does not have to wait for the outcome of the Senate's deliberations to proceed with negotiations in the Council.

${ }^{207}$ The respondent is referring to relations between the executive and the legislative branches in EU affairs
} 
cooperate at the administrative level. Government and parliament staff talk to each other relatively often, so the final position accommodates the two visions".

The parliamentary administration has never attempted to hire external experts to provide assessments of EU or domestic issues, although pro bono contributions are occasionally used. In the opinion of a former staff member of the EU Unit (C6), the response from the Chancellery of the Senate to requests for money to hire additional expertise would have been negative. A current member of the Parliamentary Institute shares the same opinion (C4): "In terms of expertise as such we try to make the most of the resources we have here: out of 60 studies per year only one or two are developed externally. It is a question of money and management of the Chamber's Chancellery. It is hard to persuade the Secretary-General to give money for external expertise". Normally, external expertise comes in the form of stakeholders' opinions or pro bono contributions. MPs also have their own budgets which can be used to acquire additional expertise, although a former staff member of the Senate administration (C6) thinks that it is very unlikely that this money was ever spent on providing expertise on EU affairs. A respondent from the Chamber of Deputies' staff (C35) argues that if this money were ever spent on EU issues it would probably be dedicated to legal aspects, although the respondent stresses that parliament has no overview of how MPs spend their personal budgets. A former clerk in the Senate's administration (C6) assumes that MPs would have little interest in expanding the pool of expertise on EU affairs. Given that there are already parliamentary staff members tasked with providing information and analysis, MPs would consider buying in external expertise on EU issues to be 'paying twice'.

In the early years of the Czech accession to the EU, a number of technical problems emerged which hampered effective conduct of the scrutiny process, such as a malfunctioning of inter-institutional information systems, delayed document delivery and late submission of translations of EU documents into Czech. The latter was mentioned as one of the major problems in the dialogue between the European Commission and national parliaments, although according to the $7^{\text {th }}$ COSAC (2007a) bi-annual report, the issue seems to have been more important to the Chamber of Deputies than the Senate. By 2009-2010 all these challenges had been resolved.

There have been ideas to make the follow-up to the scrutiny process more systematic. For example, in 2010-2011 a proposal was discussed in the Chamber of Deputies to introduce compulsory follow-up checks on a three-month basis for key EU dossiers that have been discussed previously. The proposal does not seem to have been developed further since. In the Senate, the follow-up mechanism remains unchanged. It is provided through annual reviews which make reference to the resolutions adopted and the government's response to them.

In the aftermath of the Lisbon Treaty, according to an NGO expert on Czech politics (C1a), both chambers do not seem to have experienced major problems with either administrative or expert support on the scrutiny process. The Czech Parliament has therefore been able to address the 'material and temporal constraints' involved in adopt- 
ing the new competences. According to both current and former staff members in the parliamentary administration of both chambers (C2, C10 and C31), their work did not qualitatively change after the entry into force of the Lisbon Treaty. Due to budgetary constraints, no new staff were hired in either the European Unit of the Senate's Chancellery or the EU department of the Parliamentary Institute, the administrative bodies responsible for providing expertise to the upper and lower chambers of the Czech Parliament, respectively.

\subsection{Role of parliamentary administrators}

Despite the fact that, according to a staff member in the Parliamentary Institute (C4), the informal code of conduct for administrators in the Czech Parliament stresses the value of political neutrality, in the aftermath of the 2010 general elections there has been growing pressure from political parties on parliamentary staff members to provide analysis that is solely based on the ideological preferences of the parliamentary majority. Attempts to politicize the parliamentary bureaucracy have taken place before, as both experts and former parliamentary staff testify (C1a, C17), but since 2010 they have arguably become more intensive as a single party (the ČSSD) has been able to take full control of the Senate. This resulted in a situation in which the governing majority and the opposition find support in different parliamentary chambers. Parliamentary staff, however, have been able to resist this pressure, which became a part of daily routine. A former staff member of the EU Unit (C10) noted: "We got continual pressure from left and right, so we ended up neutral". Another respondent from the Senate's administration (C2) argued: "I can confirm that we experience political pressure but this is nothing new. Several years ago we had a different majority and there was pressure on us, may be not as explicit as now. Our unit was suspected of being too much to the left, now too much to the right". Judging the current situation in the Senate, a former member of the Senate's administration (C17), who left the upper house in 2010, argued: "Maybe $\mathrm{it}^{208}$ is just an overblown feeling as the staff were used to the pressure from the right, and now it is coming from the left". Several respondents have argued that in the aftermath of the 2010 elections the Czech Social Democratic party started treating Senate staff as party staff. A staff member in the EU Unit (C27) gives the following assessment of the increasing political pressure on parliamentary administrators: "For a long time we had a right wing government (headed by Topolanek) and a right wing parliament, so we were not used to tension as the Senate was copying the government's position. We as staff were not happy, we were not that Eurosceptic, we provided some arguments that the government says is not always right; there can be some good stuff from the EU. In most of the cases we did not succeed in changing MPs' opinions as politicians wanted to support the government, and we were perceived as leftist. Now with a new majority we are perceived as rightist. But we are not political staff'. Staff members in the Cham-

\footnotetext{
${ }^{208}$ The respondent is referring to alleged instances of political pressure.
} 
ber of Deputies (C5, C31b and C16b) confirmed the assessment of their colleagues from the Senate. Parliamentary staff member in the lower chamber $(\mathrm{C} 16 \mathrm{~b})$ says that "there is more pressure on the colleagues. Staff are asked why they did this, if they do something ideologically different from the ČSSD. The vice-chair of the Senate was saying that they are too right wing and that they need to change."

The tendency to politicize parliamentary staff is much more pronounced in the Senate, where the opposition has secured a majority, than in the Chamber of Deputies. Occasionally, according to a respondent from the administration of the lower house (C16a), the government also makes suggestions about which outcome of the scrutiny process it would find desirable, but in such a case it is the rapporteur or a member of parliament, not the parliamentary administrators, who are approached. Despite the fact that staff appointments are generally transparent, cases have started to appear of MPs attempting to promote their 'own people' into the cadre of Senate staff dealing with the EU. So far such attempts have not been successful.

In the aftermath of the 2012 elections to the Senate, when the Czech Social Democratic party (ČSSD) consolidated its control over the upper chamber, the staff have developed a new pattern of cooperation with political parties. Apparently, the debate over the so-called Monti II directive in the Czech Parliament triggered this new pattern of cooperation. Initially, MPs paid limited attention to the Monti II proposal, despite warnings from parliamentary staff that this case was very important. A respondent from the Chamber of Deputies (C31b) explained: "We warned members of the European Affairs Committee about Monti II but they did not pay any attention. There was a detailed opinion from the Parliamentary Institute but no response from the ČSSD or any other party interested in the issue - not the Communist Party of Bohemia and Moravia (KSČM) or even the Civic Democratic party (ODS)".

This later led to a sense of frustration among Czech political parties when the "yellow card' was passed and MPs started to realize that they had ignored an important proposal. As a result, parliamentary staff now try to be more proactive, flagging up politically salient issues and communicating them directly to political parties / the central offices of political parties, not just individual MPs. Allegedly, this helps alleviate potential conflicts between representatives of political parties and parliamentary staff. Under this scheme, parliamentary staff are not agenda-setting or promoting a specific policy solution, but trying to present political parties with a number of options from which they can choose. This is primarily a 'safeguard measure' for parliamentary staff to avoid political pressure. A staff member of the Senate (C36) elaborated on this new pattern of relations with political parties in the aftermath of the 2012 elections: "We have established a new working model that we try to communicate with political parties as early as possible what we think could be important to them. So basically we try to put on their glasses and see what might be sensitive for them.... We are here for you if you have any political guidance for us as far as drafting resolutions. We try to avoid the conflicts that happened in the past before they reach the final stage of scrutiny here in 
the Senate....So that political parties can have politically sensitive issues under their control from the very beginning. This has helped a lot and we have not had much pressure on us in terms of changing what we write in our papers, analyses and reports. We only try to show them which proposals should be dealt with more care from their perspective". This new pattern is reminiscent of Swedish practice, where parliamentary staff draft resolutions that reflect the positions of different political parties. By adopting this new scheme of relations, the parliamentary staff seek to prevent themselves from getting embroiled in any kind of political debate and make it clear to political parties that they, the MPs, have a carte blanche in terms of choosing policy alternatives.

The effectiveness of this new approach by parliamentary staff to relations with MPs can be hampered by the fact that partisan officials do not always respond. As a staff member at the Senate (C36) noted, "we communicate more with party experts. We try at least but the response is not always there". Another staff member at the Senate (C8b) elaborated on the same issue: "Everybody is notified but obviously the larger parties have experts who are working on EU affairs. The smaller parties do not necessarily have designated people in the party clubs. So sometimes there is no one to talk to....It depends on whether they ${ }^{209}$ read what we send them and how actively they deal with these things. They can communicate with us when they want but we cannot do everything for them".

Experts (C1a) as well as members of the Czech Parliament (C9, C22, C25) agree that parliamentary staff in both chambers are fully capable of delivering good quality expertise, but it often has a limited impact on parliamentary debates due to the lack of interest of MPs. While the information provided by the Parliamentary Institute in the Chamber of Deputies or the European Unit of the Senate is not necessarily crucial for the large parties (ODS, ČSSD), smaller political parties heavily rely on it. A respondent from the Chamber of Deputies' administration (C16b) argues that 70 per cent of information requests to the Parliamentary Institute come from small parties that do not have enough staff or other mechanisms to monitor EU affairs.

For the large parties, the information provided by parliamentary experts is just one of several information channels that can be cross-checked. An administrator from the lower house $(\mathrm{C} 16 \mathrm{~b})$ illustrates this attitude by making reference to a statement by a senior member of the EAC in the Chamber of Deputies: "I can use the party track do get information but I also want to use the Parliamentary Institute to analyse EU proposals". As another respondent from the Chamber of Deputies' staff (C35) argued, political parties could get information on EU issues without the help of the Parliamentary Institute, solely on the basis of their party contacts, but this would mean that they would get material in a non-systematic manner. In any case, MPs have carte-blanche in terms of taking on board the suggestions of parliamentary experts. A senior staff member at the Chamber of Deputies (C35) expanded on this topic: 'Parliament is considered in the Czech Republic a continuation of 'party matters'. Everything that is connected to par-

${ }^{209}$ The respondent is referring to the Czech political parties. 
liament is understood as a matter of party policy. An independent analytical structure in parliament does not fit this pattern. They even fear it would be too independent - it is not desirable for the functioning of parliament under this approach,210.

Acute inter-party rivalry in the Senate - and to a lesser extent in the Chamber of Deputies - often does not allow an 'upload' of the technical expertise provided by parliamentary staff into plenary or committee debates. This creates a strong sense of frustration among staff members of both chambers (C2, C5, C6 and C8a). As a former member of the Chamber of Deputies (C22) mentioned, “...parliamentary staff dealing with EU affairs are also ashamed because they do good work about which few care". As a practitioner (C27) claimed, the legal framework for subsidiarity checks is in place and staff fully able to provide competent assistance but the interest in EU affairs is absent. Another former member of the Czech parliamentary staff (C17) has a slightly different perspective, arguing that "it is hard to say whether the interest of MPs has declined or risen in general, but it is clear that knowledge about the EU does not go beyond a certain restricted set of people. The level of interest has fluctuated both for people and for the committee in general". This necessarily limits opportunities for parliamentary staff to shape the outcome of scrutiny as by minimizing requests for expertise and analysis, political parties deny parliamentary administrators the only legitimate way to get involved in the policymaking process.

According to staff members in both the Chamber of Deputies and the Senate $(\mathrm{C} 2$, $\mathrm{C} 10$ and $\mathrm{C} 31$ ), the tasks of parliamentary administrators have not changed qualitatively since the Lisbon Treaty. The introduction of new 'mandating' powers for both chambers has not profoundly affected the day-to-day work of parliamentary staff, according to a member of the Senate's EU Unit (C2). In both parliamentary chambers, the EAC secretariats deal more with managerial issues, such as booking flights and organizing meetings, according to members of the parliamentary administration (C5, C16a), while the work of the EU department at the Parliamentary Institute and EU Unit in the Senate chancellery is geared to providing expertise. The European Affairs Committee secretariats in both parliamentary chambers are also instrumental in brokering meetings with chairs, and defining the final version of the draft committee work programme. Currently, the secretariat of the EAC in the Chamber of Deputies has three staff members and two assistants. The EAC secretariat in the Senate is comprised of two people, as well as a special post of an adviser to the committee who concentrates mainly on subsidiarity issues. In 2006 the EU Unit became part of the foreign affairs department of the Senate Chancellery (it was previously being responsible directly to the chancellor). In the opinion of a former EU Unit staff member (C7b) this diminished the amount of administrative work the unit had to do, as it was no longer responsible for its own accounting, booking trips, and so on. It is noteworthy that, according to the estimation of the Czech Senate's representative in the European Parliament (B16a), of a staff of around 200 in

\footnotetext{
${ }^{210}$ The respondent (C35) does not refer to the PI, considering it too focused on legal aspects, but to the creation of a new analytical body within the Czech Parliament.
} 
the Senate Chancellery, only seven deal with EU issues. The EU Unit works primarily with the European Affairs Committee, while 60 to 70 per cent of the work of the EU department of the Parliamentary Institute also deals primarily with the European Affairs Committee in the lower parliamentary chamber $(\mathrm{C} 16 \mathrm{a})$. This is a continuous process established after the Czech accession, which does not seem to have been changed by the Lisbon Treaty. Some respondents from the parliamentary administration (C2, C16a) suggested that more staff would be beneficial, but this opinion was not universally shared by all parliamentary administrators. One challenge particular to the Senate administration relates to the fact that while EU law is covered by the EU Unit, the preparation of national draft legal acts is under the control of the Legislative Unit. The schedules of these two bodies are not aligned, but both current and former members of the EU Unit $(\mathrm{C} 2, \mathrm{C} 6)$ argue that this does not constitute a major problem. Arguably, this situation makes it more difficult to make MPs aware of the relevance of EU proposals and their impact on national policy.

The limited number of staff involved in providing expertise on EU affairs does not seem to compromise the quality of scrutiny as the designated officials are working full time on EU issues and have access to a wide range of information sources, including informal contacts with government officials. Nonetheless, the limited number of staff causes other problems. For example, the representative of the Czech Senate in the European Parliament (B16a) argued that due to the fact that EU documents and expertise on EU affairs are provided by more or less the same people for a long period of time, the 'socialization effect' is diminished as knowledge of EU procedures remains somewhat concentrated within a small group of administrators. Nonetheless, the capacity of this limited pool of dedicated parliamentary staff to obtain information through informal contacts in the government is considered very high and effective, according to the administrators' own assessment (C2, C23).

Although some key personnel have left these expert structures for the government or the private sector, staff turnover has been more or less stable in the past two or three years. A ban on hiring new staff was introduced due to the economic and financial crisis. If someone leaves, argues a staff member of the Parliamentary Institute (C16a), his or her place is only covered by another nomination in a case of the utmost importance. Staff members change jobs almost exclusively for economic reasons, as for example staff in the Parliamentary Institute have not received a pay rise for three years ${ }^{211}$. For many, a job in the Parliamentary Institute or the EU Unit is their first job after university, according to a staff member in the lower chamber (C5). In addition, parliamentary administration structures do not offer much scope for career development. As an academic expert on Czech politics put it (C3), "by the time these people gain experience, they are ready to leave and search for other jobs". Special focus is put on the links be-

\footnotetext{
${ }^{211}$ Some experts (C3) claim that the absence of a civil service code is another problem, although other respondents do not consider this a key challenge to parliamentary administration. One expert stressed that in the administration of the Czech Parliament there is "no systematic work of getting good staff".
} 
tween parliamentary staff members and academia. Many have doctorates and / or teach at universities. These links with academia have been encouraged, for example, by both previous and current heads of the Parliamentary Institute. It is considered a way of securing information channels and an additional mechanism for career development and financial support. In addition, close links with academic experts and combining jobs in parliamentary administration and academia could make the scrutiny process faster and possibly alleviate the constraints imposed by the eight-week timeframe for conducting subsidiarity checks. Although a former member of the Parliamentary Institute (C23) argued that "academia is slow", she also agreed that working in academia provides the necessary informal connections that are useful in mobilizing experts on an ad hoc basis.

In general, parliamentary staff seem to be more concerned with making sure that the position of both chambers, regardless of its content, is made known to and taken into consideration by the government - not promoting a specific policy goal. On the other hand, parliamentary staff have tried to promote some new scrutiny practices. For example, several former staff members in the Czech Parliament have been instrumental in setting up and promoting the idea of an MP-MEP dialogue. In the opinion of one of them (C17), however, "these meetings did not materialize into something we expected but nevertheless the meetings did take place. The initiative for these meetings came from the administrative level, not the political one". This shows that even if administrators come up with an initiative for reform, MPs are free to shape the new rules and practices according to their own interests.

It should be stressed that the provision of expertise by parliamentary administrators or their assistance in developing the agenda is controlled by representatives of the political parties. For example, even if the staff of both chambers are persistent in identifying cases where parliament could issue a mandate, there have been a very limited number of cases in which this has been done. The following quote captures the self-perception of parliamentary staff (C8a): "I am not here to tell members of parliament what to do; I just have to find possible problems in the document and tell them".

\subsection{Role of parliamentary committees}

The scrutiny of EU documents depends on good cooperation between the two European Affairs Committees and the sectoral committees. In the years immediately after the Czech accession to the EU, however, the involvement of sectoral committees proved a challenge. To a large extent this problem has not been resolved to this day, as the participation of standing committees in the scrutiny process often remains ad hoc. In practice, although the European Affairs Committees in the Senate and the Chamber of Deputies are not bound in any way by the advisory opinions of other sectoral committees, the views of the latter are taken into consideration in most cases. There are no strict legal regulations on how and to what extent the opinions of sectoral committees must be considered by the respective EACs. 
Ultimately, it is up to the European Affairs Committee to decide whether an EU proposal is submitted to other relevant sectoral committees and what the timeframe for deliberations should be. Relations between the EAC and the standing committees depend a lot on the formal status of the European Affairs Committee. In the Chamber of Deputies, the European Affairs Committee can present an opinion on behalf of the whole lower chamber; hence it acts as a veto-player where other sectoral committees are involved. Arguably, it also has less incentive to cooperate or integrate other committees than the Senate EAC. The latter cannot speak on behalf of the upper chamber and its resolutions have to be confirmed by the plenary. The formal conditions for involving sectoral committees in EU affairs scrutiny are potentially more conducive in the Senate.

Involving sectoral committees in the scrutiny of EU affairs remains a challenge for the Czech Parliament. This is confirmed by both the academic literature (Suchman in Iglesias and Blanco 2010) and the interview data from members of the Senate (C25). Arguably, not much has changed since the issue was first flagged up by Pitrova and Coxova (in Tans 2007), although the problem seems to be more acute in the Chamber of Deputies. A respondent from the Parliamentary Institute (C16a) describes the relationship between the European Affairs Committee and sectoral committees in the lower chamber: "This cooperation is rather rare, the response rate from sectoral committees is not good, still the same as Pitrova described it. Sometimes sectoral committees even call and ask why we have sent them a document, as they have plenty of work already". In the Senate, the situation is somewhat different. A former member of the Senate's administration (C17) noted: "Before I left, ${ }^{212}$ there was a clear trend towards involvement of other standing committees, both in terms of quality and quantity. Committees begin to accept that the EU is also part of their work, but still would not gather just to discuss an EU agenda so there can be delays in delivering opinions".

The level of cooperation between European Affairs Committees and standing committees changes on a case-by-case basis. When an opinion from a standing committee is really needed, the chair of the European Affairs Committee gets in touch directly with the chair of the respective committee and makes sure that an opinion is delivered on time. The involvement of sectoral committees has not helped much in spreading knowledge of EU topics. In the scrutiny of the EU's policy proposals discussed above (the Green Paper on pensions and the Proposal) sectoral committees were either not involved (Senate on both documents; Chamber of Deputies on the Proposal for a directive on seasonal migrants) or participated after a resolution by a European Affairs Committee had already been passed (Chamber of Deputies on the Green paper on pensions): Arguably, the problem of limited communication between the EAC and standing committees is more of an issue for staff members. In their interviews members of the Czech Parliament (C9, C12) argued that limited cooperation between the European Affairs Committees and the standing committees was not a huge problem for them and could be overcome just by going to other committee meetings. Among the staff, howev-

${ }^{212}$ The respondent left the Czech Senate administration in 2010. 
er, any forceful centralized attempt to make communication better might provoke turf wars. As a respondent from the Parliamentary Institute (C5) put it: "If resistance to take EU issues on board exists, it mainly comes from the standing committee staff, not MPs".

The timing of scrutiny may constitute a handicap to cooperation between the EAC and standing committees. The challenge is not so much to produce high-quality expertise within stringent time limits but organizing and scheduling meetings. For example, the work in the Chamber of Deputies is organized in a six-week cycle with only two 'committee weeks'. In practice only one committee week takes place, with the agenda being crammed into one day. This often leaves little time to deliberate on EU issues. In addition, when there is an extra plenary session there is less committee time and a higher chance of missing the eight-week time limit for contributions to subsidiarity checks. Ultimately, as staff members in the lower chamber (C16b, C31b) argues, the European Affairs Committee in the Chamber of Deputies is able to have 'normal' sessions only once in six weeks to two months, although most of the meetings are irregular.

The European Affairs Committee is not very popular among members of the Czech parliament. As a member of the lower chamber's administration $(\mathrm{C} 16 \mathrm{a})$ argued, there are no 'political points' that can be gathered by MPs for serving on the EAC. This was corroborated by a former staff member of the EU Unit (C10) who said that "stars do not work in the EAC". The same respondent argued that few parliamentarians apart from committee chairs have a comprehensive knowledge of EU issues. A parliamentary administrator from the lower house $(\mathrm{C} 16 \mathrm{a})$ noted: "The truth is that the EU agenda is not popular among the deputies". By 2013 the status of the EAC had not increased, according to the same member of parliamentary administration (C16b): "It is not a prestigious committee. It is not a powerful committee, powerful like the agriculture or economic committee where you decide things which have a direct impact on the Czech Republic and convey political points. In the EAC it does not work like that. The motivation of members of the committee is quite low, the issues which are discussed are too wide, you have to specialize in so many things that it is difficult to work like an expert". Experts from NGOs (C1a) and parliamentary staff members (C8b) agree that in most cases MPs who 'end up' on the EAC have simply been unable to secure positions elsewhere.

This lack of interest among MPs is seen by parliamentary administrators (C2, C8a, B28) as one of the main drawbacks in the scrutiny of EU affairs. As a staff member at the Chamber of Deputies (C35) argued: "There is little interest in EU affairs from the majority of deputies. There are a few individuals but it is symptomatic these people are usually losing influence in domestic politics, isolating themselves. The EU is like a hobby for them. Some of them are not re-elected because they lose in the region or electoral district. Those who do not count on re-election - do EU affairs....If people have no expertise or capacity on domestic issues, someone says to them "Go to the EU committee, you cannot spoil anything there". I am not even speaking about language capabilities. Language is one thing but interest and expertise and willingness to move 
things foreword are another. And I do not feel it. It is a symptomatic reflection of the lack of a clear Czech position / interest in the EU". Former MPs (C22) and parliamentary administrators (C23) share this opinion, claiming that "membership of the EAC is never a priority for a member of parliament" as "everybody wants to be on the budget committee". Ultimately, it seems that in both strong and weak parliaments EU affairs are not among the preferences of MPs, as in both the Swedish and the Czech Parliament the EAC does not enjoy a high ranking in the informal hierarchy of parliamentary committees. It is noteworthy that the assignment of a rapporteur position on an EU dossier to a particular member of parliament has almost never been contested by another MP. Members of the Czech Parliament (C12) and parliamentary staff (C16a, C27) confirm that EU subjects are pre-assigned at the beginning of an electoral term, depending on the preferences and expertise of MPs, leaving little room for conflict over rapporteur nominations in the domain of EU affairs.

The situation around the position of the EAC Chair in the Senate in the aftermath of the 2010 elections is quite symptomatic of the low prestige of the EAC. Both current and former members of the Senate administration (B16a, C27) argued that despite the victory of the ČSSD in the 2010 Senate elections ${ }^{213}$, the position of the EAC Chair, held by a member of the centre-right ODS, was not contested as there were more important committees to control. Moreover, in the sixth term of the Chamber of Deputies, the turnover of deputies in the European Affairs Committee was very high, which arguably made it difficult for MPs to develop 'institutional memory' and a profile on EU affairs. Another example of limited interest in EU affairs could be the fact that, according to one expert $(\mathrm{Cla})$, the head of the EAC in the Chamber of Deputies, despite being interested in EU affairs, was not able to increase the status of the EU agenda and MPs' interest in it, allegedly due to inter-party disagreements. All this evidence highlights how the EACs in both chambers have limited 'committee identity' and input into policymaking. A former member of the Senate staff (C6) noted that: "Looking at individual committees in the long term you see them change as the political majority changes, so apparently party identity is stronger; no committees are strong just because they are respected committees".

\subsection{Role of political parties}

Differences in the relative representation of political parties affect the relationship between the two parliamentary chambers as they attempt to block each other's actions ${ }^{214}$. Conflicts on EU issues run not between government and parliament, but between the

\footnotetext{
${ }^{213}$ In contrast, the parliamentary majority in the Chamber of Deputies sixth term belonged to the center-right coalition of the Civic Democrats ODS, 'Tradition Responsibility Prosperity 09' party (TOP 09) and the deputies who were previously members of the Public Affairs Party (VV)

${ }^{214}$ For example the Proposal of the European Parliament and of the Council establishing a European Institute for Gender Equality (COM 200481 final) was supported by the Chamber of Deputies but rejected by the Senate
} 
governing coalition and the opposition parties. To practitioners, a scenario involving a conflict between the government and both parliamentary chambers seems highly improbable, according to a staff member at Parliamentary Institute $(\mathrm{C} 16 \mathrm{a})$.

As noted above, in the Chamber of Deputies European Affairs Committee speaks for the whole chamber, but in the Senate the resolutions of the EAC have to be adopted by the plenary. However, in both cases it is the political parties that play a crucial role in the way the decisions of the European Affairs Committees are addressed by the respective plenaries.

In the Chamber of Deputies the plenary almost always reaffirms the decisions taken by the $\mathrm{EAC}^{215}$ as the same party that has a majority in the committee has a majority in the plenary. According to a staff member in the lower chamber $(\mathrm{C} 16 \mathrm{a})$, the plenary has overruled the decision of the EAC only once and only then because when the resolution of the European Affairs Committee was adopted, more members of the opposition were present than of the governing coalition. The resolution was unrepresentative of Chamber of Deputies' opinion and later had to be revoked.

In the Senate, the plenary acted as a 'gatekeeper' on the resolutions of the European Affairs Committee as the EAC was chaired by a member of the Civic Democratic Party, while the plenary in the Senate was controlled by the Social Democratic party ${ }^{216}$. As a result, the resolutions of the European Affairs Committee were often changed in the plenary. "Anything too critical of the EU will not be accepted by the parliamentary majority", according to a staff member of the Czech Senate (C8a). A former member of the Czech Senate's administration (C6) shares this assessment: "The leadership of the Senate is very cautious and reviews what comes out of the European Affairs Committee to check if anything goes against the line of the Party of European Socialists ${ }^{217}$. Now the EU committee has a much harder time pushing through the issues in the plenary". On several occasions, inter-party conflict degenerated into direct accusations of the EAC chair by the Speaker of the Senate, according to a member of the EU Unit (C2). Moreover, when senators come up with proposals that do not correspond with the ideology of their party, they are heavily criticized. As a former member of the EU Unit (C6) noted, "when a proposal/resolution which is critical of the EU is presented by a member of a pro-European socialist party, it creates panic in the leadership of the Senate. Who drafted it and who provided information on it? Sometimes they do not support their own rapporteur and do not take up these comments in the resolution. This is a problem of internal procedures within the parties".

\footnotetext{
${ }^{215}$ The EAC can submit a resolution to a plenary vote, although it is not obliged to do so. According to parliamentary staff the EAC submits a resolution to the Chamber of Deputies plenary once or twice a month ${ }^{216}$ This conflict lingered on until the by-elections to the Senate in late 2012. Afterwards both the EAC and the plenary in the Senate came under the control of the Czech Social Democratic Party. However, the conflict between the upper and the lower chambers continued as the former was controlled by the opposition and the latter by the ruling coalition

${ }^{217}$ An umbrella organization comprised of national Social Democratic parties from the EU member states, EEA states and a number of third countries.
} 
According to staff members in the Czech Parliament, there are few, if any, signs of cross-party cooperation in the EACs, which could have led to a situation where individual MPs escape political control of party groups. European Affairs Committees do not seem to have developed a 'political identity' of their own as their actions tend to reflect partisan majorities in both chambers. For example, current and former staff members of the parliamentary administration in both chambers $(\mathrm{C} 6, \mathrm{C} 16)$ argued that voting in the Chamber of Deputies' European Affairs Committee goes strictly along party lines. The respondents mentioned above argue that even if deputies think differently, party discipline and incentives to stick to the party line prevail. As a staff member of the Parliamentary Institute (C16a) noted: "They vote along party lines, one side of the table against the other. I think in 90 per cent of the cases they do not vote independently, they have prior agreements and have red lines from parties". Respondent C5 argued in a similar way: "The EAC is divided according to political lines; they vote according to party lines even if an MP thinks it would have been better the other way". According to a respondent from the administration of the Chamber of Deputies (C31b), this pattern of voting along party lines remained fully operational in 2013. Parliamentary administrators $(\mathrm{C} 5, \mathrm{C} 10)$ mentioned that as a result of political tensions, even cross-party socializing among MPs became a much rarer event. Political parties seem to structure the debates in the European Affairs Committees, diminishing the chances of the latter to becoming more autonomous from partisan influence and acquiring more independent input into the scrutiny process.

According to Holzhacker $(2002,2005)$, the involvement of the opposition can contribute to the quality of the scrutiny process as in principle the pressure exerted by the opposition on the government forces the latter to develop more efficient and legitimate policies. Nonetheless in the case of the Czech Parliament (especially its upper chamber) the dominance of the opposition has only triggered inter-party rivalry. Although the main parties in the governing coalition and the opposition hold different attitudes towards the European Union, consistent partisan voting in the European Affairs Committees seems to relate more to the logic of inter-party rivalry than to support for EU integration. A member of the Chamber of Deputies (C9) provided one example: "The ČSSD are Keynesians, they criticize the government for cutting the budget but support the neo-liberal fiscal compact ${ }^{218}$ ". The scrutiny process is used to put pressure on the government and demonstrate the power of the opposition. For example, according to a former member of the EU Unit (C7b), items were being taken off the Senate's agenda by some Social Democrat senators, who were previously known to favour an 'expertise-orientated' inter-party debate, just to 'flex muscle' and demonstrate power vis-à-vis the government. As a result, according to an academic expert (C18), the level of conflict in the plenary has arguably moved current Czech parliamentary practice away from the 'working parliament' ideal-type to a more UK-inspired model, in which

\footnotetext{
${ }^{218}$ The respondent is referring to the Treaty on Stability, Coordination and Governance in the Economic and Monetary Union (TSG)
} 
open conflict in the plenary is much more acceptable. Ultimately, in the opinion of a former staff member in the upper chamber $(\mathrm{C} 7 \mathrm{~b})$, inter-party rivalry harms the scrutiny process as expertise and content-orientated assessment become much less salient and there is greater risk of missing important technical elements of EU proposals.

As a result of the Senate elections in November 2012, the ODS lost control of the EAC, which acquired a new chair ${ }^{219}$, and the ČSSD was able to consolidate its control over the upper chamber. The conflict between the EAC and the plenary has been resolved due to the change in committee leadership, but the confrontation between parliamentary chambers remains intact. As one of the Senate's staff members (C39) put it: "After the 2012 elections the majority of the ČSSD is solid, so there is no contest of power in the upper chamber. There is not much rivalry because there is no point in being bitter".

Party politics can also 'backfire' in the sense that inter-party conflict and the low saliency of EU affairs among the parties can hinder the normal functioning of the scrutiny process. For example, the Chamber of Deputies EAC was devoid of leadership for 18 months in 2008-2009. The conflict over the post of the European Affairs Committee chair was triggered when a member of the Green Party, initially earmarked for this position, moved into the government and, according to a parliamentary administrator (C5), "was doing too many things at the same time". After the initial candidate of the Green Party left for a ministerial position, a potential candidate to take up the position of chair came from the Civic Democratic Party. According to a former member of the EU Unit (C17), however, the Civic Democratic Party did not regard it as worth changing the coalition agreement in order obtain the chair of the EAC, and possibly lose control of other, more important, committees. As a result, the Green Party found it hard to select another candidate, as two Green MPs who could take up the job declared themselves independent. One of the respondents from the Parliamentary Institute (C16a) described the situation: "The Greens could not occupy the position of committee chair but did not want to give it up". According to a former member of the Chamber of Deputies (C22), although other parties did not want to take up the post of EAC chair, they were not ready to accept the Green Party candidate for this post. As the representative of the Czech Chamber of Deputies in the European Parliament noted (B6a), the Green Party candidate could not rely on sufficient parliamentary support and was appointed only at the third attempt. According to a staff member of the Parliamentary Institute (C5), this was a difficult time for the parliamentary administrators in the lower chamber as "in order to get a decision we needed to consult four vice-chairs". In the end, the Green Party member who took up the post was unable to develop a good working relationship with the rest of the EAC as members of the committee boycotted sessions and questioned the chair's professional skills. This shows how inter-party conflict undermined the normal functioning of the scrutiny process in the lower chamber, and that there was little interest in resolving it as EU issues were not considered a priority.

${ }^{219}$ The new head of the EAC is not affiliated to a political party. 
Ultimately, according to a former member of the EU Unit (C6), when the work of the lower chamber in the EU domain practically ceased, the Senate took over the EU policy dossier, gaining profit from the inactivity of the Chamber of Deputies. During this time, there were occasions when the government negotiation mandate said nothing on the position of the chamber to which it is formally accountable, but referred only to the opinion of the Senate. As a former member of the Senate's administration (C21) argued, the Senate ultimately adopted the role of defender of the national constitutional order, both externally and internally, deciding to 'specialize' on EU affairs.

The climate of acute inter-party rivalry generates little demand for expertise in EU affairs. For example, staff members at the Chamber of Deputies (B6c, C5) claimed that the opposition ČSSD is not fully aware of all the procedural opportunities, such as interpellations etc., that exist to promote its opinion, relying more on the 'weight of numbers' (as in the Senate) than on argumentation. This marginalizes parliamentary administrators as their leverage and input into the scrutiny process is proportional to the demand for expertise. When there is little demand for such analysis, there are few opportunities for parliamentary staff to shape the scrutiny process. Arguably, few MPs make a direct connection between EU proposals and the domestic policy process, given the limited demand for EU expertise. For example, the lower chamber's rapporteur on the Green Paper on pensions was from the opposition (Communists of Moravia and Bohemia / KSČM), but his criticism was directed to the EU's attempt to acquire more competence in social policy and not to the direction of pension reform, which the Czech communists are highly sceptical about due to the fact that it goes against their belief in the sustainability of the public pension system. Despite the fact that parliamentary parties hold varying opinions about the EU, none went into much detail when analysing the Green Paper on pensions and the Proposal for a directive on seasonal migrants. A staff member at the EU Unit (C2) argued: "The Civic Democrats (ODS) are sceptical towards the EU but the reality of this scepticism is such that they do not care about the EU. The Social Democrats (ČSSD) have a more positive approach but sometimes thinks positively about the EU without further reflection. Between these two parties there is a difference in the general approach but not much attention paid to content". The Eurosceptic attitudes of several Czech political parties do not seem to have resulted in a more in-depth assessment of EU proposals.

Inter-party rivalry in the Czech Parliament has also affected its participation in the Early Warning System. For example, although the Czech Senate is much more active in EU affairs than the Chamber of Deputies, it has passed only one reasoned opinion ${ }^{220}$. The Senate is reluctant to pass more due to the conviction of the Czech Social Democrats (ČSSD) that reasoned opinions might compromise the pro-European image of the

\footnotetext{
${ }^{220}$ In 2013 the Senate passed its second reasoned opinion, which addressed the functioning of the Eurojust (COM 2013 0535), but it was not supported in this by the Chamber of Deputies. By early 2014 both chambers had passed three reasoned opinions, but only in the case of the Proposal for a directive on seasonal migrants have the Chamber of Deputies and the Senate issued a reasoned opinion in relation to the same document.
} 
party and provide political benefits to the Civic Democrats (ODS), their key and more Eurosceptic political rivals. A staff member of the Senate (C8a) argued: "The reason that we had only one reasoned opinion is that we had too little time and not much chance but mostly it is a matter of partisan politics. The dominant party, the Social Democrats, is keen on the EU. The Civic Democratic party is considered Eurosceptic. The Social Democrats are pro-EU in order to distinguish themselves from the Civic Democrats.... None of the parties is using arguments. It is ideological". Another respondent from the Senate administration (C27) developed this topic: "Nobody wants to issue a reasoned opinion even if the European Unit conducts an analysis stating there might be a subsidiarity breach. We warn MPs but they do not want to send a signal that we have problems with something that comes from the Commission". Nonetheless, in the aftermath of the 2012 Senate elections, the attitude to reasoned opinions started to change, allegedly because the Social Democrats feel more secure in the upper chamber. A parliamentary administrator (C39) commented that: "Previously, issuing a reasoned opinion was considered to be a sign of Euroscepticism, which is not true. If you issue a reasoned opinion, you do your job seriously and use the powers which are conferred on you by the Lisbon Treaty. Now it is the consensus among the senators that a reasoned opinion is ok". Ultimately, inter-party disagreements over the use of the new competences provided by the Lisbon Treaty were triggered not only by different attitudes towards the EU, but primarily by concerns over how the new competences would affect party image and party cohesion.

The high level of conflict between the Civic Democrats (ODS) and the Social Democrats (ČSSD) can result in a situation in which two separate versions exist of reasoned opinions or communications by the Czech Senate. According to a former member of the EU Unit (C10), a less critical version is sent to the EU institutions in order not to compromise the pro-European stance of the ČSSD, and a more critical version is archived 'for domestic use'. According to the abovementioned respondent, this is done to somehow put pressure on the government, making it aware that the upper chamber does not unconditionally support its policies. This issue does not seem to have acquired a high profile. The European Commission is fully aware of this practice by the Czech Parliament, according to a former member of the Romanian Parliament (R1c), but considers it an internal matter for the Czech Republic.

Attempts to 'exit' to the EU level have also been driven by party interests. For example, the ČSSD has complained several times to the European Commission that the government has allegedly not properly discussed several documents related to the 'European Semester' ${ }^{221}$, although the Commission avoided taking sides and the request had no further consequences according to the representative of the Czech Senate in the European Parliament (B28). The Czech Senate has attempted to create a coalition of parliaments to file a 'yellow card' against the Proposal for a directive on seasonal migrants.

${ }^{221}$ See Chapter 4 for the definition of the 'European Semester' 
It seems that the initiative came from the Civic Democratic Party ${ }^{222}$, although the Social Democrats supported the move. Several national chambers, for example the Romanian Parliament, were contacted with a request to look at the proposal, but the Czech Senate was not able to secure the necessary support.

Contacts between Czech MPs and Czech MEPs do not seem to play a crucial role in policymaking in the Czech Parliament. There is little evidence that they have been used to put pressure on the Czech Government. The rules of procedure of both chambers allow for participation by Czech MEPs in EAC meetings in a purely advisory role, although this provision is rarely used, mostly due to differences in schedules. There are bi-annual Czech MP-MEP meetings modelled on the British experience but, in the opinion of staff members from the lower house (C15, C16a), participation is not very high. As a parliamentary clerk (C36) noted, "we want to enhance the effectiveness of these MP-MEP meetings as so far they have been rather formal. You see your colleagues from Brussels, from the European Parliament but the substance is not really there". The event is used more for information sharing and networking than for lobbying or coordination of policy activities, according to an academic expert on Czech politics (C3). As a member of the lower chamber (C9) put it, "the greatest gain from the Czech MP-MEP meeting is the collection of cell phone numbers. It helps make connections but is not really used to lobby". The event is arguably more useful for the Czech Permanent Representation, who, according to one Czech senator (C11), plays a big role in organizing MP-MEP meetings and establishing connections with MEPs to promote national interests.

One of the main challenges for the Czech scrutiny process is that MPs have a low level of interest in EU affairs. The list of Czech MPs who participate in meetings with officials from the European Parliament, MEPs and representatives of the EU institutions could serve as a proxy for identifying Czech MPs who specialize in EU affairs. According to a former staff member at the Senate (C17), the list has not changed much since the early 2000s as "visits to Brussels are hard work and there are not many volunteers". The same respondent recalled that around the time of the Czech Presidency in the first half of 2009, a list of the 'usual suspects' for visits to Brussels was established (for example, L.Sefzig, A.Gajduškova, J.Bauer, T.Grulich ${ }^{223}$ ), which, according to the representatives of the Czech Parliament in the European Parliament (B6c, B28) has by and large remained unchanged. This means that expertise in EU affairs in the Czech Parliament has not moved beyond a limited cadre of MPs. Given the fact that several of these MPs with considerable expertise in EU issues left parliament after the 2013 election, it is likely that the 'average level' of knowledge of Czech MPs about EU affairs has decreased.

\footnotetext{
${ }^{222}$ According to respondents (C19), the few senators with an interest in migration affairs and the EU are from the Civic Democratic Party.

${ }^{223}$ As of April 2014 L. Sefzig is the former head of the EAC in the Senate, A.Gajduškova is the vice-president of the Senate, J.Bauer is the former head of the EAC in the Chamber of Deputies and T.Grulich is a senator
} 


\subsection{Evaluation of the Czech parliamentary practice}

In the aftermath of the Lisbon Treaty, the focus of scrutiny in the Czech Parliament has been on the division of competences between the EU and the domestic levels, as the analysis of the scrutiny of the Green Paper on pensions and the Proposal for a directive on seasonal migrants shows. The Lisbon Treaty triggered the development of mandating rights in the Czech parliamentary rules of procedure, but in general the Czech scrutiny system has remained somewhat path-dependent and fixed to the document-based ${ }^{24}$ ideal type. Close contacts between government and parliamentary staff as well as an absence of a sharp executive-legislative conflict on EU affairs are likely to persist. Interparty rivalry, which in the Czech political context can also mean inter-chamber rivalry, ${ }^{225}$ seems to be the key factor in determining the evolution of the scrutiny system, although it is not directly connected to attitudes to the EU. Parliamentary experts saw relatively little demand for their work as relations between the parliamentary majority and the opposition became highly conflict-orientated, making comprehensive scrutiny of EU proposals less important. The limited involvement of standing committees in the work of the European Affairs Committee also precludes the spread of knowledge about the EU. Political parties, as opposed to parliamentary administrators and committees, have the crucial role in agenda-setting, structuring the discussion of EU affairs and defining the scrutiny procedure.

This important role for political parties means that the concepts of 'voice', 'threat of issue exit' and 'neglect' relate primarily to MP behaviour in the post-Lisbon political environment. It can be argued that 'voice' remains the key reaction of political parties to the new 'opportunity structure', whether it is exercised formally through interpellations and other procedures or informally through inter-party contacts. Due to the dominance of the opposition in the Senate, 'voice' of the Social Democrats in the upper chamber will become more powerful as the governing coalition is forced to negotiate. 'Threat of issue exit' has also been used primarily in the Senate, rather than the Chamber of Deputies, allegedly because in 2010-2013 the opposition had a stronger presence in the upper chamber. Introducing two versions of a reasoned opinion or a communication as well as complaining to the European Commission about the lack of consultations with parliament have been clearly geared to putting pressure on the Czech Government. It should be noted, however, that the 'threat of issue exit' is used sparingly by the Czech Parliament. It seems that the saliency of EU affairs is not considered high enough for parliamentary actors to establish comprehensive policy coordination with EU-level bodies and actors in order to influence the government.

It is worth recalling that both the Czech Senate and the Chamber of Deputies assess the effect of the 'Barroso dialogue' primarily in terms of quantitative change, that is, in

\footnotetext{
${ }^{224}$ See Chapter 1 for a definition of document-based scrutiny.

${ }^{225}$ However, in the aftermath of general elections in late 2013 a coalition led by the Social Democrats took control of both the Chamber of Deputies and the Senate.
} 
the increased number of documents received. In the COSAC sixth bi-annual report (COSAC, 2006b) it is stated that in the opinion of both chambers the added value of political dialogue with the European Commission is mainly in establishing a channel of communications in parallel to the EU Extranet of the Council, to which both chambers were already connected. Nonetheless, the Senate made greater use of the opportunities provided by the 'Barroso initiative' compared to the Chamber of Deputies. In 20062009 it was one of the most active parliamentary chambers (European Commission $2010)^{226}$. While the Chamber of Deputies was reluctant to send a representative to the European Parliament, doing so only on the eve of the Czech Presidency, the Senate sent a representative to Brussels in 2004, as it considered involvement in EU affairs an opportunity to carve out a distinct political niche for itself.

It is noteworthy that none of the Czech parliamentary actors have exploited contacts with EU level actors and stakeholders to influence domestic scrutiny of the Green Paper on pensions or the Proposal for a directive on seasonal migrants. Representatives of the Czech Parliament in Brussels were not asked for extra information on the Green Paper after the Commission presented the documents to the representatives of national parliaments in May 2010, as a representative of DG EMPL (B9) confirmed. In addition, during hearings held in the European Parliament on the seasonal labour migrants' directive in November 2010 no contacts were made between the Czech senator present and the European Parliament rapporteur on the issue. According to a member of the upper chamber $(\mathrm{C} 11)$, the meeting was set up in such a way that MPs could only react to the views of MEPs and not promote their own policy suggestions. Brussels-based organizations such as the European Trade Union Confederation or Business Europe were also not consulted. The offices of Czech stakeholders in Brussels, such as the Czech confederation of industry, were not approached either, according to a former member of the EU Unit (C7a). No contacts were made with European Parliament's party group rapporteurs ${ }^{227}$. Nor were Czech MEPs (B36, B38) contacted directly ${ }^{228}$.

Despite the fact that Czech political parties use 'voice' and 'threat of issue exit' in the scrutiny process, factors such as the lack of interest on the part of Czech national parliamentarians in the content of electorally salient EU proposals as well as the low status of the European Affairs Committee in the Czech Parliament's internal hierarchy show signs of a certain neglect of EU affairs. Another sign of 'neglect' in reaction to the new 'opportunity structure' is the fact that even a more proactive stance by parliamentary staff towards MPs could not force political parties to pay greater attention to EU affairs and move the scrutiny process beyond its focus on the division of competences.

\footnotetext{
${ }^{226}$ European Commission (2010). Annual report 2009 on relations between the European Commission and national parliaments. COM (2010) 291 final. Brussels 02.06.2010

${ }^{227}$ See the respective references to interviews in the European Parliament in chapter on the Swedish Parliament.

${ }^{228}$ Only two interviews / responses to electronic questionnaires could be arranged with Czech MEPs. None of the respondents in Prague mentioned that MEPs were contacted about the Green Paper on pensions and the or the Proposal for a directive on seasonal labour migrants.
} 
Acute competition between the governing and the opposition parties is likely to be conducive to 'neglect' as when only feeble mechanisms for reaching consensus are in place inter-party conflicts create little demand for expertise and comprehensive in-depth scrutiny of EU affairs. 


\section{CHAPTER 7: Parliamentary scrutiny of EU affairs in the Romanian Parliament}

This chapter addresses the evolution of Romanian parliamentary practice in the aftermath of the Lisbon Treaty. It is shown that the key problem of the Romanian scrutiny system has been the lack of a clear legal basis for executive-legislative relations in the domain of EU affairs, something that was resolved only at the end of 2013. The chapter argues that political parties have used debates about the legal basis of scrutiny of EU affairs as a bargaining chip. There has been little interest among Romanian MPs from either governing or opposition parties in finalizing the debate on executive-legislative cooperation on EU issues. It is shown that even after the adoption of a new law, several vaguely defined legal aspects of executive-legislative relations remain, which may pose a challenge to the scrutiny of EU affairs in the Romanian Parliament.

\subsection{Evaluation of EU proposals on pensions and labour migration policies in the Romanian parliament ${ }^{29}$}

Before April 2011 both chambers of the Romanian Parliament had a Joint European Affairs Committee (Joint EAC). The two policy proposals were considered within this 'old' setting, as their scrutiny was conducted in late 2010 and early 2011. According to staff members at the Romanian Senate administration (R13), the Green Paper on pensions was discussed only briefly. A former staff member at the Romanian Parliament (R1a) describes the debate over the Green Paper on pensions as a "vague formal meeting". Given the fact that six members of the opposition and six members of the ruling coalition were present, only the vote of the chair could have resolved the gridlock. However, as he was not present it was decided to pass no formal resolution on the Green Paper. According to Senate staff members (R13) all of the Joint EAC members agreed that growing demographic pressure constituted a real challenge to the Romanian pensions system and raised doubts about it sustainability. Even so, they did not have strong opinions for or against the Green Paper. It seems that the standoff between the members of the Joint EAC had more to do with demonstrating party unity and political rivalry than differences in the assessment of the EU proposal. A background note on the Green Paper was prepared by the Directorate for Community law (a body in the Chamber of Deputies administration responsible for providing EU expertise) but staff members at the directorate (R9) claim that this did not constitute formal scrutiny report. The

\footnotetext{
${ }^{229}$ The author would like to thank V.Gasca and A.Nastase for assistance in translating documents of the Romanian parliament
} 
document was more of an overview or summary of the European Commission's proposal and did not provide much in terms of evaluating the policy solutions proposed by the $\mathrm{EU}^{230}$.

The Chamber of Deputies discussed the White Paper on pensions after the Joint EAC had been split. According to a staff member at the European Affairs Committee in the lower chamber (R8b), "the White Paper on pensions was discussed but did not cause any political problems, it was consensual". A resolution of the Chamber of Deputies ${ }^{231}$ on the White Paper on pensions was passed on 25 June 2012, stating that the design of pension systems should remain within the remit of member states and that EU institutions should play only a coordinating role in pension system reform.

The Proposal for a directive on seasonal labour migrants was not on the priority list of the Joint European Affairs Committee. It is important to note that the suggestion to scrutinize the document came from the Czech Senate, which attempted to establish a coalition of national parliaments against the EU proposal and contacted the Romanian Parliament with a request to assess the EU document. At first, the discussion of the Proposal for a directive on seasonal labour migrants was conducted among staff members in the Directorate for Community law and the Joint EAC secretariat, not by MPs. The background note on the Proposal by the Directorate for Community law was presented on 15 December 2010. The document was more of an explanation and summary of the Proposal for a directive than a critical analysis of it. The background note argued that the Proposal would not have any substantial influence on the domestic labour migration regime. Statistical data from the Romanian Immigration Office was included in the document, highlighting that there had been only 400 seasonal migrants in 2011 , although no information about their country of origin was given.

During the debate in the Joint EAC, the key concern of the Romanian Parliament was how the directive would interact with restrictions on the free access of Romanians (and Bulgarians) to the labour market of other EU member states, and affect Romanian seasonal workers involved elsewhere in the EU. Romanian MPs were concerned that seasonal migrants could exploit legal loopholes in order to acquire an opportunity to settle in the EU. The Romanian Government had similar concerns. Ultimately, the debate in the EAC focused not on the impact of the EU proposal on national labour migration policies but on the potential competition between Romanian and third-country seasonal workers in the EU labour market. However, no breach of subsidiarity was detected in relation to the Proposal for a directive on seasonal migrants.

In addition to the Joint European Affairs Committee, two standing committees were involved in the scrutiny process of the seasonal migrants' dossier: the Committee on labour and social protection and the Committee on legal matters, discipline and immunities. The former conducted its assessment in late January 2011. No major reservations about the Proposal were raised, although potential subsidiarity concerns were

\footnotetext{
${ }^{230}$ Information sheet №77. October 2010 (http://www.cdep.ro/afaceri_europene/afeur/2010/fi_690.pdf)

${ }^{231}$ http://www.cdep.ro/eu/docs/F362747427/Opinie\%20CDep\%20COM\%2055.pdf
} 
raised in connection with article 12 of the document, which covered conditions of reentry for seasonal migrants. The committee was also concerned about temporary contracts for migrants becoming permanent, as well as a excessive financial burden resulting from the obligation to provide 'adequate accommodation' to seasonal migrants. The committee argued that third country nationals were being put in a position that was more favourable than the situation of Romanian and Bulgarian citizens who were still denied free access to the labour market of several EU member states.

The Committee on legal matters, discipline and immunities was specifically asked to identify potential subsidiarity and proportionality breaches. The committee presented its opinion in December 2010. It acknowledged that the eight-week period envisaged by the Lisbon Treaty for providing an assessment of compliance with subsidiarity has expired, so its opinion could be expressed only within the framework of political dialogue with the European Commission. The committee claimed that the justification presented by the European Commission for this proposal was not sufficient as it impinged on the sovereign rights of member states and failed to see that regulation of seasonal labour migration could be better addressed at the national level. Despite the fact that the committee acknowledged that the Proposal for a directive set only minimal standards for the treatment of seasonal labour migrants, and that member states could still set quotas for the admission of seasonal migrants, it stated that the EU proposal created an additional and excessive financial burden on both public authorities and employers.

The recommendations of the committee on legal matters, discipline and immunities were not taken into account by the Joint EAC, which presented its final and unanimous opinion on 1 March 2011. The Standing Bureau of the Chamber of Deputies did not wish to submit the resolution to the plenary. The Joint EAC claimed that the Proposal for a directive did not alter the status quo in the domestic regulation of migrant labour and did not violate the principles of subsidiarity or proportionality. The opinion of the government was integrated into the document. Article 16 of the Proposal of the directive, which addresses social security issues, and the potential consequences of these provisions for the Romanian welfare system, were not noted during the scrutiny process in the Joint EAC. A staff member of the European Affairs Committee in the Chamber of Deputies (R8a) described this omission: "We had plenty of comments but this particular issue we just missed". This means that the Joint EAC overlooked one of the most controversial aspects of the Proposal for a directive.

\subsection{Domestic rules of procedure, material and temporal constraints}

It is important to note that in the case of Romania, the adoption of the provisions of the Lisbon Treaty was taking place in an environment that was not conducive to greater parliamentary involvement in policymaking. As is argued in Chapter 2, existing typologies of national parliaments consider the parliament in Romania to be a political institution with little influence. One of the reasons for this low status is the incessant inter- 
party conflict and the rivalry between the executive and the legislature. Preparing for EU accession did not improve the domestic standing of the Romanian Parliament and did not increase its role in formulating national policies (Ghinea et al. 2010). Adoption of the acquis was hampered by continuous coalition infighting in an attempt to secure parliamentary majorities. The government relied heavily on ordinances, a specific type of bill that can enter into force without the approval of parliament, which ultimately leads to weaker parliamentary influence and establishes a tradition of consulting parliament on very rare occasions or disregarding its opinion altogether.

Initially indispensable during the course of the political transformation of late 1980 s, and introducing a considerable number of amendments to the government's bills, the Romanian parliament slowly lost ground in terms of setting the legislative agenda (Ionescu 2011). In addition, the lack of a clear understanding of the type of policies that would be pursued once the country became an EU member state (Papadimitrou and Phinnemore 2008) diminished the potential input of the Romanian Parliament. Moreover, in the aftermath of accession, the EU topic was marginalized even further as constant political conflicts between President Trajan Basescu, different prime ministers, and the governing coalitions and the opposition dominated the political landscape (van Meurs 2009).

The Joint EAC was established in December 2006, on the eve of accession, bringing together members of both the Chamber of Deputies and the Senate. In practice, however, given that both houses were dominated by different political majorities, it became increasingly difficult to develop a common approach to scrutiny procedures and document selection. Each chamber had a different schedule, so it was problematic to organize meetings and hearings of the Joint EAC. In the run-up to Lisbon Treaty ratification, suggestions to split the Joint EAC became increasingly prominent. The idea found more support in the Senate, while the Chamber of Deputies mounted tacit resistance as it provided the bulk of the Joint EAC staff and, hence, had secured control over the internal dynamics of the committee. The Joint European Affairs Committee was split in the spring of 2011.

The main challenge for the scrutiny of EU affairs in the Romanian Parliament, however, is not the format or the composition of the European Affairs Committee but the legal framework for executive-legislative cooperation on EU issues. As representatives of both Romanian parliamentary chambers in the European Parliament argue (B1, B2a), it proved extremely difficult to establish a system of executive-legislative cooperation on EU affairs, which fell victim to the adversarial relations between various ruling coalitions, opposition parties and different branches of government.

The first draft of the law on cooperation between the government and parliament on EU issues was registered in December 2006, but by late 2013 seven drafts of this law have been discussed. The large number of drafts is partially explained by the fact that according to the Romanian Parliament's rules of procedure, if a legislative proposal is still pending at the time of new elections it must be removed from the agenda and regis- 
tered again in the new parliament to continue deliberations. Given the frequent changes in parliamentary majorities and coalitions in the Romanian Parliament, discussion of the draft law was effectively marginalized.

Government Decision 115/2008 served as a provisional basis for executivelegislative cooperation on EU affairs until the legal framework was finally adopted. This document stipulated that decisions of the European Affairs Council ${ }^{232}$ should be submitted to parliament 'for information' after an agreement had been reached at the central government level, so there was limited opportunity for parliament to participate in the elaboration of the country's policy towards the European Union or provide a mandate for the negotiations in the Council of Ministers. The fact that the government decision was not formally approved by parliament made the legislative base for executive-legislative cooperation on EU affairs even more vague (Ghinea et al. 2010). This reticence by the government in negotiating the executive-legislative framework for cooperation could be explained by the fact that it feared that increased parliamentary involvement might make negotiations in the Council more difficult and hamper the formulation of a Romanian position. Allegedly, administrative capacity of the Romanian Government in EU affairs is still somewhat underdeveloped. Hence, involving parliament on a larger scale, according to the executive's logic, would simply complicate the preparation of a national negotiation position, according to a representative of the Romanian Chamber of Deputies (B1). Respondents from the administration in the lower chamber (R9) framed the problem differently: "The parliament is considered to be a printer, not a processor". Parliament is not perceived to have the capacities to make a positive contribution to the decision-making process. At the same time, EU policies are treated as international affairs, not 'domestic policies' as such, triggering few demands from MPs for better coordination and involvement in carrying-out and defining Romania's EU policy. In the absence of a full-scale legal system of executive-legislative cooperation, an ad hoc system of consultations with government officials has developed, although staff members at the Senate (R13) argue that these consultations do not provide any real leverage for parliament.

The draft which served as a basis for the current law on executive-legislative cooperation on EU affairs was prepared by the Ministry of EU affairs and introduced to the Romanian Parliament in December 2011. According to a former clerk in the lower chamber (R1b), the draft was not clear about how EU proposals should be selected for scrutiny, the legal status the opinion of parliament has, and so on. The Chamber of Deputies tried to make the scrutiny system stronger by introducing a large number of amendments to the government $\mathrm{draft}^{233}$. Many amendments dealt with definitions of a reasoned opinion and other legislative documents. Scrutiny was defined (in both the

\footnotetext{
${ }^{232}$ A body chaired by the prime minister and attended by various members of the cabinet in order to establish Romania's priorities in the EU.

${ }^{233}$ This section is based on the joint report (March 2012) of the Committee on Legal Affairs and the EAC of the Romanian Chamber of Deputies, which lists both the government proposal and the amendments introduced by the lower house.
} 
government and the parliamentary versions) as the evaluation of EU legislation and its impact on national policies. The definition made no reference to the task of controlling the EU policies of the Romanian Government or defining its scope of action in the Council.

The draft prepared by the Ministry of EU affairs and the amended text prepared by the Romanian Chamber of Deputies differed in several crucial respects. The first issue was the legal status of parliament's opinion in relation to government policies. The government version argued that the position of parliament was to be taken into account but should not be binding, while parliament suggested that "the position of parliament should be used to finalize the national negotiating position". On the other hand, the parliamentary version of the draft explicitly stated that the prime minister, and ministers for EU affairs or foreign affairs should explain the Romanian position before each European Council meeting. This could imply that parliament does not merely have 'advisory' functions but plays a more proactive role in shaping the country's policy towards the European Union.

The government version claimed that oral and, on rare occasions, written explanations could be given if the government deviated from the pre-agreed position. Parliament's version adopted a stricter tone, demanding written explanations to be delivered in the shortest possible time. Parliament also suggested introducing a 'scrutiny reserve' procedure, obliging the government to wait for a joint common position of both chambers. If arriving at a common position of both chambers proved impossible, the executive would be free to choose the position of one of the chambers.

The timeframe for scrutiny and the delivery of government memoranda was another aspect where the two versions of the law differed. The version by the government claimed that scrutiny should be launched within five days of the receipt of an EU document, while parliament did not impose any temporal restrictions. Both the executive and the legislature agreed that the government would be notified of the start of the scrutiny process within three days. There were also differences over when the final opinion of parliament should be delivered. The government version claimed that it should be done within 20 days of the start of the scrutiny process, while parliament demanded that it could be at least three days before the final negotiation date in the Council. The government version also mentioned that the text of the parliamentary opinion had to be submitted to the executive within two working days. Failure to meet these conditions would mean that the government could decide on its own.

The draft law had a number of provisions that were unclear, which could have inhibited the conduct of parliamentary scrutiny. For example, the draft law referred to subsidiarity and proportionality checks but did not provide detail on how they should be conducted. By and large, various sections of the law repeated the provisions of Protocol 2 of the Lisbon Treaty.

The final version of the law with amendments suggested by the Chamber of Deputies was not voted on as the document was not put on the agenda of the plenary, even 
though it only needed a simple 'yes-no' vote. For procedural reasons (lack of a quorum and consecutive delays in discussions), the draft law passed to the Senate in its initial government version and the amendments proposed by the Chamber of Deputies were ignored. According to a staff member of the EAC in the lower chamber (R8a) and an MP from the Chamber of Deputies (R2), the Chamber decided to overcome this alleged marginalization by lobbying for its own amendments through like-minded senators, who were keen to increase the role of parliament in policymaking.

In the autumn of 2012, the law was finally approved by the Senate with the Chamber's amendments included, but the law was then declared unconstitutional by the Romanian Constitutional Court (Decision №784, 26 September 2012). The motion was submitted by a group of senators from the Democratic Liberal Party (PDL), allegedly to support President Basescu who was vying with the Romanian prime minister over who represents Romania in the meetings of the European Council. Interestingly, the president of the Romanian Chamber of Deputies supported the senators from the Democratic Liberal Party, even though he was from the rival Social Democratic party. The debate around the law on executive-legislative cooperation on EU affairs ultimately became centred around the mode of representing Romania in the European Council, not the role of the Romanian Parliament in EU affairs. Eventually, the law was considered to go against article 80 of the Romanian Constitution ${ }^{234}$, violating the right of the Romanian President to represent the country at the EU level. The ruling of the Constitutional Court did not pay much attention to the involvement of parliament in EU affairs and concentrated instead on the division of competences between president and prime minister. Article 3 of the proposed law was also declared unconstitutional, even though it only mentioned that parliament should issue opinions that had to be taken into consideration by the government while drawing up its negotiation position. The reasoning of the Constitutional Court was based on the fact that the Romanian Constitution did not formally provide for parliament to issue 'opinions' as opposed to laws and decisions.

The lack of a clear legal framework posed a number of challenges for day-to-day cooperation between the government and parliament. The ability of the latter to issue a mandate and shape the executive's position remained one of the central questions. The Joint European Affairs Committee provided such a mandate on an ad hoc basis, but formally speaking it lacked a strong legal basis for doing so. The government did not seem to take this mandate seriously. For example, according to a staff member in the EAC in the Chamber of Deputies (R8a), even if the executive presented its provisional positions for Council negotiations, these were later changed without informing the parliament. The government did not fear any political repercussions.

In 2013 the debate around the law on executive-legislative cooperation on EU affairs focused again on the mechanism for representing Romania in the European Council, not on the role of the Romanian Parliament. The formula, which was designed in close collaboration between the government and the parliamentary chambers, envis-

${ }^{234}$ Article 80 stipulates that the President of Romania shall represent the Romanian state. 
aged that if president and prime minister could not agree on who represents Romania within several weeks before a European Council meeting ${ }^{235}$, the choice would be delegated to the Romanian Parliament, which would decide the matter in a plenary meeting of both chambers. As a former staff member at the Romanian Parliament (R1d) noted, this formula was intended to by-pass President Basescu as the parliamentary majority would try to support their party members in the executive. A representative of an NGO (R3b) supported this assessment: "Ultimately, this debate has nothing to do with the scrutiny procedure as such but just with the question of who represents Romania and the inter-institutional conflict ${ }^{236}$ ". The ruling by the Romanian Constitutional Court, however, stipulated that the president represents the country and that reference to any 'arbitrage' by parliament must be deleted from the legal text.

The law on executive-legislative cooperation on EU affairs was finally adopted at the end of 2013, under the title "Act on cooperation between the Parliament and the Government in the field of European Affairs (Law 373/2013)" despite the fact that the President Basescu attempted to stall the law by referring it yet again to the Constitutional Court, which found no unconstitutional provisions in the new legal act.

The new law makes several changes to the role of parliament in conducting scrutiny. First, parliament finally acquired the formal right to mandate the government, although this right seems to be stronger in relation to the government's actions in the Council of Ministers than the European Council. The wording of the "Act on cooperation between the Parliament and the Government in the field of European Affairs" means that the position of parliament must be taken into account when a negotiating position for the Council is set up. In cases where the parliamentary chambers fail to develop a joint resolution, that is, when their opinions diverge, or it is not sent on time, the government has free reign to adopt its own negotiation strategy. The wording of the document in relation to the mandate for the European Council is softer. Although the government must present its mandate to both parliamentary chambers, parliament is not obliged to provide instructions. Moreover, the President of Romania is under no strict obligation to present a mandate for the European Council. Given that according to the ruling of the Romanian Constitutional Court he is responsible for representing Romania at the European Council, it is unclear who has the formal authority to present the country's mandate before the Romanian Parliament if the president does not do so.

Law 373/2013 does not stipulate how exactly both chambers have to develop a common position on the government's mandate, which raises serious concerns about how the law will be implemented and whether parliament will be able to use it to increase its influence. Furthermore, article 3.2 of the abovementioned Law states that "the resolution of the Parliament or one of its chambers shall be taken into account by the

\footnotetext{
${ }^{235}$ In 2012 president Traian Basescu and prime-minister Victor Ponta had a conflict over who should represent Romania at a European Council summit.

${ }^{236}$ The respondent was referring to the 'inter-institutional' conflict between the prime minister and the president.
} 
Government when settling the negotiating positions in the Council as provided in the mandate". It fails, however, to specify the criteria based on which the government will have to decide whether the opinion of the Chamber of Deputies or the Senate should be taken into account. Nor does article 75 of the Romanian Constitution, which addresses the competences of the Chamber of Deputies and the Senate, provide any guidelines.

Second, as was argued by a staff member of the secretariat in the Chamber of Deputies (R8b), as a result of the new law resolutions of the EAC will now need to be confirmed by plenary votes in both chambers. In the Senate, the resolutions of the EAC already had to be voted on in the plenary. The previous practice in the Chamber of Deputies obliged the Standing Bureau of the lower chamber to decide whether a resolution of the EAC had to be put to a plenary vote. A member of the European Affairs Committee in the lower chamber (R2) described this practice as the 'sovereignty of the plenary', implying that it can overrule decisions made by standing committees. The abovementioned respondent acknowledged, however, that the plenary had rarely used its right to change decisions made by standing committees. Ultimately, it remains to be seen how greater involvement by the plenary in the Chamber of Deputies will affect the dynamics of the scrutiny process. At the time of writing, both chambers are adapting their standing orders to the new law on executive-legislative cooperation on EU affairs. What shape the new formal rules will take remains to be seen.

The "Act on cooperation between the Parliament and the Government in the field of European Affairs" does not resolve a number of issues, which may complicate the scrutiny of EU affairs and hamper the ability of the Romanian Parliament to shape the national government's policy on EU affairs. The first issue is the abovementioned lack of clear criteria on whether the national government has to develop its mandate on the basis of the opinion of the Chamber of Deputies or the Senate in cases where the opinions of the two chambers diverge. In practice, this could mean that the executive will simply chose the opinion of the chamber in which it has the support of the majority. The law does not provide a clear timeframe for the two chambers to reach an agreement on the government's negotiation stance, so this is likely to be negotiated on a case-by-case basis. Moreover, the Law 373/2013 does not foresee any specific mechanisms for parliament to follow up on the changes that the government can singlehandedly make to its negotiation mandate, apart from 'ordinary' interpellations and questioning. The new law on executive-legislative cooperation does not foresee any automatic delivery of government memoranda on draft legislative acts of the European Union. This will be done only on request from one or both chambers, limiting the ability of MPs to assess EU issues. The provisions on 'scrutiny reserve' are also not conducive to greater parliamentary influence as their enactment depends on the ability of both chambers to develop a joint opinion. In cases where the Senate and the Chamber of Deputies fail to do so, the 'scrutiny reserve' is automatically lifted. Taking the abovementioned issues into consideration, it is doubtful that the new legal framework will help the Romanian Parliament 
achieve greater influence in EU affairs. On EU issues, it is likely to remain a consultative body.

Throughout 2006-2013, technical and administrative back-up with deliberating on EU issues in the Romanian Parliament was provided by the EAC secretariat ${ }^{237}$, the Directorate for Community Law in the Chamber of the Deputies and the European Affairs Directorate of the Senate. These bodies normally provide expertise on EU issues to sectoral committees too. It is noteworthy that most information on EU issues comes from the government, as the basis of scrutiny is a government memo. This 'expertise asymmetry' between parliament and the government is exacerbated by the fact that, according to NGO experts on Romanian domestic politics (R6, R11), the information systems of the government and parliament are not necessarily well-aligned. All these factors limit the ability of parliamentary administrators to support the effective scrutiny of EU affairs.

\subsection{Role of parliamentary administrators}

Long-term problems with the legal basis for executive-legislative relations in EU affairs are not the only challenge facing Romanian parliamentary scrutiny. The ability of the Romanian Parliament to address the 'temporal and material constraints' associated with implementing the provisions of the Lisbon Treaty is open to question. It is difficult to attract and retain high quality staff, according to a former member of parliamentary administration (R1a), so parliament relies on a cadre of long-serving civil servants who maintain the 'institutional memory' of the departments dealing with EU affairs. A member of the European Affairs Committee (R2) described these long-serving staff members as "the ones who prepare everything for us". Some long-serving parliamentary staff members are approaching retirement age and it is unclear whether the parliamentary administration will be able to attract new highly skilled staff. It will face a challenge to ensure a smooth 'transition' from the older generation of civil servants to a younger cadre of parliamentary staff, and it is unclear whether the segment of the parliamentary administration dealing with EU issues will be able to provide career opportunities for younger staff members. In addition, according to experts (R6) and parliamentary staff (B2c), there have been no open competitions or recruitment exercises for positions in the public administration since 2008, so the temporary ban on hiring has stimulated a 'brain drain' from the public sector ${ }^{238}$. For example, the Directorate for Community law has 18 staff members, and four or five vacancies to be filled once the ban on hiring is lifted. Half the staff members in the lower chamber who deal with EU affairs are on temporary contracts.

\footnotetext{
${ }^{237}$ In spring 2011 separate secretariats were created for European Affairs Committees in both chambers.

${ }^{238}$ In the interview with R8a there was an inference that staff members can be linked to political parties. "In a perfect world they (the EAC staff) would be selected in a perfect way...if they are prepared enough, if they are eager enough, if they are supported by political entities".
} 
Young people tend to leave after a year or two of work in the EAC secretariats. In the opinion of a former staff member of the Romanian parliament (R1c), the 'best and brightest' tend to choose the executive, which provides better pay and career options. On the other hand, recruitment to positions in the parliamentary staff (and to the civil service in general) is often conducted informally, as is sometimes the case with advisers or staff of the standing committees or other members of the parliamentary administration. For example, a former member of the Romanian parliamentary administration (R1c) says that "advisers of sectoral committees do not undergo a selection procedure; they are just hired at the standing committee chair's request". This could raise questions about the political neutrality of staff members. Moreover, there have been several nominations to minor posts in the administration of the Senate which allegedly contradict the official suspension on hiring new staff. Administrators from the Senate (R13) mentioned that one assistant was hired within the framework of cooperation between the upper parliamentary chamber and the National School of Political Science and Public Administration (SNSPA). When informed of this practice, a former member of the administration in the Chamber of Deputies (R1b) called it 'illegal'. Recalling his experience in a situation of a temporary job freeze, he argued that "we had volunteers but could never find a legal way to hire them or use them full-time for research". Apart from non-transparent hiring practices and concerns about neutrality, another challenge facing the parliamentary administration, especially in the newly formed Senate EAC, is the lack of additional training and study trips to Brussels due to financial constraints (R8a).

There have also been divisions among parliamentary staff on the issue of choosing the optimal way to develop a legal scheme of EU scrutiny. In 2005-2006 the staff in the Joint European Affairs Committee secretariat were willing to develop a strict mandating system emulating the Nordic model from the start. A former member of parliamentary administration (R1a) argued that "the secretariat took it as a matter of pride to push for a radical variant", which met consistently staunch resistance from the government. In addition, the staff of the Joint EAC were allegedly closely linked to the Romanian Social Democratic Party. The staff at the Joint EAC secretariat consisted almost entirely of the civil servants seconded from the lower chamber, which was dominated by the Social Democrats. There was only one Senate clerk whose office was located separately, and he did not play a major role in the work of the secretariat ${ }^{239}$. "It was like an exile", according to a respondent from the Senate's administration (R13), commenting on the experience of the Senate's clerk in the Joint EAC. According to staff members in the Directorate for Community Law in the lower chamber (R9), the set-up of the Joint EAC

\footnotetext{
${ }^{239}$ The composition of the Joint EAC is also depicted differently by respondents R1 and R8, who are both acquainted with the work of the Chamber of Deputies. R8 argued that the Senate was always fine with having almost no 'representatives' among the Joint EAC staff, while R1 claimed that there were some unsuccessful attempts by the Senate to bring in more of its own people.
} 
secretariat was the result of an initial agreement that the Senate purportedly wanted to change later, but with little success.

The staff of the EU division, which later became the Directorate for Community Law, were more cautious in terms of pushing for a mandating scrutiny system, suggesting a more cooperative approach as parliament, in their opinion, had no capacity to compete with the government or force it to accept parliament's views. They feared that parliament would simply waste its time in trying to convince the government to accept a 'mandating system' and would be better concentrating on developing a more collaborative approach. Allegedly, the fact that the Joint EAC secretariat lobbied for strong mandating powers was related to the close association between its staff and the Social Democrat Party, which tried to use the debate over mandating powers to put pressure on the government. The 'EU division' of the parliamentary administration remained more technical, considering it better to at least establish a consultative legal framework for executive-legislative cooperation than to have nothing. It could be argued that these conflicts between the different bodies of the parliamentary administration lost their saliency once it became clear that the topic of executive-legislative relations in EU affairs had been marginalized.

Nor did tensions between the EAC secretariats and the expert bodies, for example, between the EAC in the Senate and its respective directorate of EU affairs, contribute to a stronger role for parliament. The most recent conflicts within the administration seemed to have very little to do with policy content or the scrutiny procedure, concentrating instead on informal status and potential benefits, according to the representative of the Romanian Senate in the European Parliament (B2c). These tensions are more pronounced in the Senate than in the Chamber. The division of competences between the Directorate for Community law and the EAC secretariat in the Chamber of Deputies can be blurred, especially when certain aspects of preparing EU dossiers are contested by the foreign affairs department of the Chamber's administration. The staff in the lower chamber (R9) gave an example that expertise is in general provided by the Directorate for Community Law, but when a Romanian parliamentary delegation goes to Brussels or at presidency time dossiers are prepared by the foreign affairs department which creates an overlap of competences between various bureaucratic bodies. Another example, according to a former staff member in the Chamber of Deputies (R1b), could be the situation in which a meeting of the Secretariat-Generals of the EU national parliaments is attended not by a civil servant with an EU portfolio but by a staff member from the foreign affairs department of the Romanian parliamentary administration. Turf wars between various bureaucratic structures are likely to persist, especially due to the fact that the administration of the Chamber of Deputies underwent a transformation in the second half of 2013. Despite the change of official titles, the division of competences in the EU domain between the EAC secretariat, the Directorate for Community Law and the Department for foreign affairs and international cooperation has not been made any clearer. 
Speaking about the tasks of the parliamentary administration, staff members in the Directorate for Community law in the Chamber of Deputies (R9) argued that the body "became more operational than it was intended in the first place; we are more administrative than research-orientated". In the opinion of the abovementioned respondents, the parliamentary administration became too focused on streamlining the flow of documents and conducting purely technical tasks, leaving few opportunities to conduct comprehensive in-depth analysis of EU proposals. This is corroborated by an NGO expert's opinion (R3), who claimed that staff in the EACs deal primarily with technical tasks, while the content of EU proposals is not much addressed. The situation is primarily linked to the limited interest of Romanian parliamentarians in EU affairs, which creates few opportunities for administrators to make a comprehensive assessment of EU proposals and obtain political influence. This does not mean that Romanian MPs completely disregard the material presented to them by parliamentary staff. It means that parliamentary administrators cannot always raise awareness among MPs and force them to have an opinion

A member of the European Affairs Committee in the Chamber of Deputies (R2) argued that the low level of interest of MPs in EU affairs is the greatest challenge for the scrutiny process in the Romanian Parliament. Experts (R3) and staff members in parliament (R9) agreed that low interest in EU issues as well lack of political incentives to address EU topics are the greatest problems of the scrutiny process. A former staff member (R1a) gave an assessment of MPs' attitudes to EU affairs: "Parliamentarians do not ask to us provide expertise. EU affairs are considered boring.... Most of our generation was somehow frustrated about the situation. Why work if there is no demand? ${ }^{240}$ And why just stay a nice piece of furniture?" Moreover, an NGO expert (R3) referred to a situation in which important ideas about policymaking, initiated by parliamentary staff, such as monitoring the success rate of Romanian proposals in the EU, were not taken on board at the higher level of the parliamentary administration. Parliamentary staff were trying to get deputies interested, showing the impact of EU requirements and pinpointing important policy proposals by the EU. Yet, on a number of occasions, according to a former member of the parliamentary administration (R1c), "tasks had to be invented" to keep staff busy as no instructions or requests to conduct analysis of specific EU dossiers were received from parliamentarians. The same respondent continued: "the interest of MPs is indeed the main problem, it is lacking....The "good and useful" noticed it soon and they left for other jobs because there were no clear career prospects". An academic expert on Romanian politics (R22) had similar ideas: "Verification of compliance with subsidiarity is poorly done - MPs do not see the reward". Other respondents from the Senate administration argued that no matter how many policy proposals the staff make, it is the MPs who have the final word over suggestions presented by parliamentary staff (R13). In addition, contacts with political parties, in terms of information exchange, are the prerogative of the EAC secretariats and not of 'expert

\footnotetext{
${ }^{240}$ The respondent was referring to the lack of demand for the analytical skills of parliamentary staff.
} 
bodies' (for example, Directorate for Community Law in the Chamber of Deputies or the European Affairs Directorate in the Senate) in both parliamentary chambers, which makes it more difficult for parliamentary staff to raise awareness of EU issues or set the agenda and promote knowledge about the EU.

\subsection{Role of parliamentary committees}

There was a lot of criticism of the Joint EAC, which ultimately led to its dissolution and the establishment of separate European Affairs Committees for each parliamentary chamber. In general, members of the Chamber of Deputies objected to the introduction of a separate EAC in the Senate, irrespective of the differences in their partisan affiliation (R2, R19). A former member of the parliamentary administration (R1c) said that the idea of creating two separate EACs was raised in the early 2000s in the recommendations of the Twinning project between the Romanian Parliament, the Hungarian Parliament and the French Senate, but the suggestion was vehemently resisted by the head of the Joint EAC who was from the Chamber of Deputies. At the same time, a dysfunctional Joint EAC meant that, "there was no Mr Europe in parliament", according to an expert on Romanian politics (R11). The same Twinning team developed a draft law on executive-legislative cooperation, but it was rejected by the government. The representative of the Romanian Senate in the European Parliament (B2b) argued that resistance to splitting the committee was mainly linked to personal vested interests, as prominent figures from the same party (PSD / Social Democrats) both supported and opposed such a move. In fact, the former head of the Joint European Affairs Committee, a member of the PSD, was opposed to splitting the committee as it would have negatively affected his influence.

Following the split of the Joint EAC both chambers adapted their respective working procedures on the scrutiny of EU laws. For example, the Standing Bureau of the Chamber of Deputies could decide whether a reasoned opinion had to be approved by the plenary or the assessment of the EAC was sufficient. In practice, according to a representative of the Chamber of Deputies (B1b), the EAC gets the final word. In the Senate, the resolutions of the EAC have to be submitted to a vote in the plenary.

Sectoral committees are involved in the scrutiny of EU affairs in a rather ad hoc manner, although the new system of subsidiarity checks in both chambers envisages that sectoral committees are the first to assess a policy proposal. The problem, according to a staff member at the Chamber of Deputies EAC (R8a), is that there are no clear provisions on how to accommodate (or not) the opinions of standing committees into a resolution prepared by both chambers. The extent to which the opinions of standing committees are to be integrated into the work of the EAC is open to interpretation, as there are no clear-cut regulations pertaining to this, according to staff members of the Directorate for Community Law (R9). Due to the fact that only parliamentarians in sectoral committees (as opposed to the staff in the Directorate for Community Law, for exam- 
ple) have the formal right to request external expertise, the group of actors genuinely interested in promoting the EU agenda in the Romanian Parliament becomes even more limited. Moreover, the Directorate for Community Law has only limited power to involve standing committees in the scrutiny of EU affairs, argue its staff members (R9): "We try to give the impression that standing committees should give an opinion but we do not have much leverage to stimulate them. The directorate cannot impose anything on political actors, on deputies. Also, it is up to the committee how to organize scrutiny. What we do is just informing about the deadlines".

It is not only the lower chamber that has problems in involving sectoral committees in the scrutiny process. According to a member of the European Affairs Committee secretariat in the in the Senate (R12), the staff of sectoral committees often argue that checking EU proposals for compliance with subsidiarity and proportionality is the remit of the EAC, while EAC staff try to explain that without the technical expertise of sectoral committees, this control would be an empty shell. The staff of sectoral committees often try to avoid the allegedly 'excessive burden' of scrutinizing EU issues. A quote from a staff member of the EAC in the Chamber of Deputies (R8a) is symptomatic of the strained relationship between the European Affairs Committee and sectoral committees: "I cannot judge what they are doing, it is not my business to consider how they work. I just receive their contributions". Hence, cooperation between the EAC and sectoral committees can be highly formal, with little attention paid to the content of EU policies.

Parliamentary administrators dealing directly with the EU receive relatively little demand for their expertise, while sectoral committees do not necessarily want to increase their burden by spending time on EU affairs. In such a situation, the leverage of EACs is limited as getting technical expertise from sectoral committees can be complicated and MPs have little interest in EU affairs. At the same time, an NGO expert (R11) argued that the quality of the contributions from standing committees is variable.

Occasional resistance from sectoral committees does not only prohibit their greater involvement in the scrutiny of EU affairs but also affects contacts with the European Parliament and MEPs. As a staff member of the Chamber of Deputies argued (R8a): "We have no reason to ask the European Parliament to double our work or for us to double their work". In another interview, the same respondent (R8b) argued that "we ${ }^{241}$ do not work a lot with other national parliaments; there is not much time to exchange information".

Work on the EAC is not considered prestigious among MPs. It can attract people who want to deal with external affairs, but for them the first choice would be the Foreign Affairs Committee. In addition, political parties carry out an internal selection procedure for people to be nominated to committees, according to staff members in the parliamentary administration of the lower chamber (R9), so 'party loyalty' dominates over a common 'committee identity'. As a former member of presidential administra-

\footnotetext{
${ }^{241}$ The respondent was referring to the European Affairs Committee in the Chamber of Deputies.
} 
tion (R5) concluded: "There is no specific committee will, it is the party which uses the committees". The abovementioned respondent (R5) also explained why Romanian parliamentarians are not enthusiastic about joining the EACs. The respondent provided an example that between 2007 and 2012, when she was engaged in monitoring the media presence in the Romanian Parliament, the work of the Joint European Affairs Committee was hardly mentioned in the media. This shows that for parliamentarians who want to be re-elected, the incentives to join an EAC are not very strong, as they receive little media attention and, consequently, cannot obtain any 'political points'.

\subsection{Role of political parties}

The positions of the political parties have greatly affected the debate over the legal framework of executive-legislative cooperation on EU affairs. Work on the new law started in 2006, when several draft projects were prepared for discussion between parliamentary staff and representatives of the government. However, according to a former member of the parliamentary administration (R1c), several days before the initial meeting was to take place the head of the Joint EAC, who was overseeing the work, argued that these negotiations could not be conducted at the technical level and that MPs had to be involved. The head of the Joint EAC came from the Social Democratic Party (PSD), which at that time was in opposition, and would have lobbied for strong mandating rights for the Romanian Parliament. Such a change in the position of the Joint EAC chair meant that the government lost interest in conducting negotiations. The debate restarted in 2007. According to a staff member at the EAC of the Chamber of Deputies (R8a), the head of the Joint EAC, who was considered one of the key figures in the PSD, filed a personal request to put the new draft law on the agenda of the plenary session. However, the document never appeared on the agenda list for the plenary ${ }^{242}$. In 2007 the chair of the Joint EAC still enjoyed a lot of informal influence and was one of the key figures in his party. It is not clear how his request to put the new draft law on executive-legislative cooperation on the agenda of the plenary could have been ignored.

In the following years the left-wing parties, including the Social Democrats, insisted on strengthening the scrutiny procedures and expressed their support for the new law on executive-legislative cooperation. However, as voting time approached the same left wing MPs who supported the law changed their opinions or took no part in voting, so there was no progress with the legal basis for scrutiny. The chair of the Joint European

\footnotetext{
${ }^{242}$ Respondents R1 and R8, who used to work in the administration of the Chamber of Deputies, provide slightly contradictory accounts of how the Romanian scrutiny system evolved. R1 links the problems mainly to the position of the Joint EAC's leadership which 'torpedoed' the draft and lost a favourable moment when the government was willing to cooperate by insisting too much on a strict mandating system. R8 considers the main mistake to be the wish to cooperate and accommodate the views of the government, presenting the actions of the Joint EAC leadership in a positive way. In any case these somewhat different accounts show that the set-up of the EU affairs scrutiny system was wrought with conflicts. Towards the end of the interview R8 argued that these were 'lost years' because the EAC pushed too hard for a mandating system.
} 
Affairs Committee, although he belonged to an opposition party, also changed his opinion. An expert (R6) confirmed that the head of the Joint EAC, despite being an influential politician "has never put his weight behind EU affairs". Another respondent from the Romanian Senate (B2c) provided the following account of the situation: "Left wing parties were willing to strengthen the position of parliament vis-à-vis the government and intended to support the adoption of the draft law on executive-legislative cooperation on EU affairs, but just before the vote was to be conducted, the representatives of left wing parties showed little willingness to support the new legislation. As a result, it was decided to postpone the vote. Even the chair of the EAC, who had previously supported the adoption of the draft law on executive-legislative cooperation on EU affairs, changed his opinion for unknown reasons. There were non-public negotiations with the government". Respondents suggested that left wing MPs changed their position and became less forceful in promoting the new law in return for 'benefits'. Allegedly, the threat of the opposition Social Democrats to push for mandating scrutiny through the chairmanship of the EAC was successively 'bought off' by the government, which wanted free reign in EU affairs. Ultimately, it seems that the change of attitude of the left wing opposition had a negative influence on the speed of adopting and developing the new law on executive-legislative cooperation.

The initiative to split the Joint EAC was also triggered by party politics and did not really come from the impact of the Lisbon Treaty. Staff members in the Chamber of Deputies and the Senate (R9, R12 and R13) refer to long-standing problems such as the non-corresponding schedules of both chambers and the challenge of developing common positions. However, the main reason seems to be the establishment of a new party, the National Union for the Progress of Romania. It did not take part in the general elections but was formed in the middle of the 2008-2012 legislative term from the former members of the Social Democratic Party (PSD) and the National Liberal Party (PNL). The new party was entitled to obtain a number of high status positions in the parliament, including a committee chairmanship. Given the fact that reshuffling committee allocations could trigger inter-party tensions, it was decided that the 'easy' way to provide the new party with a senior post in parliament would be to divide the Joint EAC and create a separate European Affairs Committee in the Senate. The Joint EAC was not considered influential, so any changes to its structure would not adversely affect the balance of power in parliament. Ultimately, the creation of the EAC in the Senate was primarily part of a power-sharing package deal between Romanian political parties that had little to do with concerns about effective scrutiny of EU affairs. The following example provides another illustration of how the debate around the Joint EAC was used by political parties as a bargaining chip with little genuine interest in EU affairs. Mircea Geoanna, the former head of the Romanian Social Democrat Party, was a vocal supporter of splitting the Joint European Affairs Committee. This led to a series of conflicts with the chair of the Joint EAC, who was also an influential member of the Social Democrat Party. According to a former staff member of the Romanian Parliament (R1a), Geoanna 
toned down his criticism of the Joint EAC in order to obtain the full backing of the Social Democratic Party for his nomination as the head of the Romanian Senate. After losing in the 2009 presidential elections and being ousted from the post of the head of the Social Democratic Party, Geoanna's key chance to continue a political career was to secure a post in the Senate. In order to do this, he needed the full support of the Social Democratic Party and as a result Geoanna made no further reference to the idea of splitting the Joint EAC. Hence, the driving force behind debates about dividing the European Affairs Committee was political bargaining and not the wish to strengthen the scrutiny process.

In general, however, discussion of EU proposals does not seem to trigger interparty conflict. "It was never the fact that the opposition contradicted the government in the EAC in a big way", a staff member at the Chamber of Deputies EAC argued (R8a). In late 2013 the same respondent (R8b) claimed that "voting in the EAC does take place but it is unanimous most of the time". This can be considered a sign of the general lack of interest in EU issues or a symbol of informal collusion and cooperation among the major parliamentary parties.

MPs made few attempts to link domestic and EU politics, according to a staff member at the Chamber of Deputies EAC (R8a): "In the European Affairs Committee I have never seen disputes over EU proposals, disputes trying to bring into local policy issues of the European Union. No parliamentary group tried to use arguments in examining a piece of legislation from the EU to create a benefit for its own position in internal politics". A member of the European Affairs Committee argued that "we need to connect EU and domestic policies and in this process the Romanian Parliament should take part" (R2). On the one hand, the current practice of 'decoupling' EU and domestic issues can be seen as an attempt to keep EU affairs in a 'safe haven' against the perennial infighting between Romanian political parties. Such an attitude makes the scrutiny system devoid of meaning, however, as one has to see the connection between EU and domestic politics to make a good assessment. As another respondent from parliamentary administration (R8a) claimed, there is such a highly developed consensus culture in the European Affairs Committee of the lower chamber that "often there is no need to take a vote". Such behaviour could be treated as a sign of the strength of "party whips' or as a sign of lack of interest in EU affairs. In the opinion of some members of parliamentary administration in the lower chamber, the exchange of views in the EAC is not very content-orientated (R9). It could be argued that MPs have tried to insulate themselves from the EU agenda. For example, parliamentary staff were able to lobby for, and eventually pass, a motion that MPs in the Romanian Parliament cannot have double membership of committees. Their hope was that by prohibiting double membership, a cadre of domestic EU experts at the political level would develop within the pool of parliamentarians. As both former and current members of the parliamentary administration confirm (R1c, R8a), however, all the parties have simply disregarded this decision as parliamentarians have few incentives to concentrate exclusively on the EU agenda. 
Talking about the way MPs assess the quality of government information memoranda on EU issues, a member of parliamentary administration argued (R9) that "if members of parliament know nothing, they are pleased with everything", adding that in general the opposition criticizes the memoranda and the ruling majority are fine with the quality of these documents. This can imply that parliamentary staff find it hard to develop an expertise-based debate on EU affairs as the MPs' attitudes are predominantly framed by the status of their party (governing or opposition) and ideological lines. Moreover, an expert on Romanian politics (R18b) argues that MPs with knowledge of the EU are either not important or have lost leverage, partially due to corruption scandals, which severely limits parliamentary involvement in defining national policy towards the EU. Moreover, the activity of parliamentary chambers on EU affairs can depend on the individual preferences of the speaker, not on a systematic assessment of a chamber's priorities. For example, when Mircea Geoanna was the speaker of the Senate, the upper chamber showed increased activity in EU affairs. After a new speaker was installed in late 2011, both EU and foreign affairs lost importance in the parliament's internal agenda.

Political parties seem to have influenced the scrutiny of EU affairs in Romania in two ways. First, as is shown above, they acted as a 'negative' agenda-setter for the development of a legal basis for executive-legislative cooperation on EU affairs. The opposition used the preparation of the law as a bargaining chip in the power-sharing game between the government and the opposition. At least some members of the opposition seem to have been willing to stall the work on the draft law in exchange for 'benefits'. Second, MPs see little electoral benefit in specializing in EU affairs. Attempts by parliamentary administrators to encourage MP involvement do not seem to have been successful.

In the case of the Romanian Parliament, the involvement of the opposition did not translate into a stronger role for the European Affairs Committee in defining national policy towards the EU, or in greater policy expertise as the functioning of the Joint EAC and the debate around the legal framework for executive-legislative cooperation on EU affairs clearly show. Political parties also tried to control the nomination of parliamentary staff and exert influence on parliamentary administrators. Inter-party conflicts in the European Affairs Committees of both parliamentary chambers seem to be more of an instrument to demonstrate dominance over political rivals than a reflection of differently articulated approaches to EU affairs.

\subsection{Evaluation of Romanian parliamentary practice}

It could be argued that the scrutiny system in the Romanian Parliament has fallen prey to inter-party infighting as well as the inability of both government and parliament to establish consensus about the legal basis for executive-legislative relations in the domain of EU affairs. Debates about the scrutiny system have been used by political parties to extort concessions, and few if any actors have a genuine interest in establishing 
effective parliamentary control over the government's EU policy. For example, although establishing the new law would have allowed the opposition to better control the government's EU policy, the unpredictability of the opposition's support greatly delayed the introduction of the new legal framework. Respondents argued that some members of the opposition were willing to adopt a different opinion in exchange for informal 'benefits'.

EU experts in the parliamentary administration have been sidelined because political parties generated little demand for EU expertise and sectoral committees were not keen on becoming involved. This created fewer opportunities for parliamentary staff to shape debates on EU affairs. The absence of a clear legal basis for executive-legislative cooperation on EU affairs also made it difficult for the parliamentary administration to manage and shape the scrutiny process as the scope of their competences remained unclear. Even though the parliamentary administration managed to address the technical problems related to the conduct of scrutiny, the question remains how the scrutiny system will evolve once longstanding staff members leave. Failure to attract 'the best and the brightest' would weaken Romanian scrutiny of EU affairs. Currently, 'material and temporal constraints' on implementing and using the Lisbon Treaty provisions are addressed by the experience and 'institutional memory' of long-serving staff members, and it remains to be seen how the system will function when they leave. In addition, attempts to politicize the parliamentary administration have not contributed to its efficiency. Parliamentary staff members occasionally seem to be affiliated with particular political parties. Moreover, parliamentary committees have failed to develop as distinct actors in the scrutiny process as political parties control both voting and nomination to the EACs, pre-empting the development of a specific 'committee identity'.

The reaction of Romanian parliamentary actors to the new opportunity structure can be best described as 'neglect'. In the first place, the scrutiny of EU affairs does not seem to have focused consistently on the content of EU proposals. MPs have shown very limited interest in EU affairs, disregarding the potentially positive synergies between EU and national policies. Second, it seems that for several years political parties have consciously postponed the adoption of the law on executive-legislative cooperation on EU affairs in exchange for other 'benefits'. Political parties acted as a veto player in drafting and negotiating the new law. The discussion of the scrutiny framework, however, served more as a bargaining tool in the power-sharing negotiations between the governing coalition and the opposition and was not focused on enhancing the role of the Romanian Parliament in formulating national policy towards the EU. It is noteworthy that according to the European Commission, ${ }^{243}$ in 2012 the Romanian Parliament has become much less active in communicating its opinions and resolutions to the EU level.

Arguably, 'voice' was also primarily used in relation to the debates around the draft law on executive-legislative cooperation on EU affairs. For example, the ruling majority and the opposition presented different drafts of the law and referred it to the

${ }^{243} \operatorname{COM}(2013) 565$ 
Constitutional Court in order to resolve the conflicts between the president and the prime minister, each supported by different partisan coalitions, over Romania's representation in the European Council. Nevertheless, 'voice' was not used to promote specific policy goals in relation to EU affairs or to reform the scrutiny system. Instead, it was used as a tool in power-sharing bargains between various ruling coalitions and opposition parties.

It does not seem that the Romanian Parliament attempted to use the "threat of issue exit' much. Moreover, the Romanian Parliament was slow to develop ties that could be used as channels for the 'threat of issue exit', such as contacts between MPs and MEPs or inter-parliamentary cooperation. In fact, the Romanian Parliament has only recently established itself on the EU stage. For example, the Chamber of Deputies opened up a representation office in Brussels in May 2007, and the Senate established one in 2010. It is important to note that until a year ago the Senate had no dedicated official in Brussels in charge of communicating its position and gathering information. This role was carried out on an ad hoc basis by the representative of the lower chamber. On the two policy cases under consideration, the Green Paper and White Paper on pensions and the Proposal for a directive on seasonal labour migrants market, there were no attempts to develop ties with the European Parliament rapporteurs or shadow rapporteurs, or with Brussels-based EU-wide organizations ${ }^{244}$. Contacts between the Romanian Parliament and the European Parliament are rather ad hoc and run along party lines, but this does not seem to work as a mechanism for policy coordination or putting pressure on the government. The administrative burden may be another reason why the Romanian Parliament has rarely used 'threat of issue exit'. On the other hand, this may also be a sign of 'neglecting' EU issues.

In conclusion, the Lisbon Treaty does not seem to have had a tangible effect on the Romanian Parliament in terms of making it a more prominent actor in EU affairs. In the words of a former staff member of the Romanian Chamber of Deputies (R1d), parliamentary scrutiny in Romania 'remains driven by civil servants ${ }^{245}$. As is noted above, the parliaments of Sweden and the Czech Republic have developed different, more proactive approaches to tackling EU issues under the 'new opportunity structure'.

\footnotetext{
${ }^{244}$ See the chapter on the Swedish Parliament for the details of respondents contacted at the EU level.

${ }^{245}$ The respondent means government officials.
} 



\section{CHAPTER 8: Analysis of the adaptation of national parliaments to the Lisbon Treaty}

According to the expectations formulated in the previous chapters, it might be expected that the behaviour of parliamentary actors in the new post-Lisbon political environment would be transformed in a number of ways. Parliamentary administrators would exert greater leverage on the outcomes of the scrutiny process due to increased demand for information and analysis of EU affairs. Parliamentary committees would experience less partisan control and develop a more independent political profile through the coordination activities of MPs and the provision of expertise. In contrast to governing parties, opposition political parties, especially in countries with minority governments, will be more interested in exploiting the political opportunities offered by the post-Lisbon environment as they acquire new instruments to redress the power imbalance. The 'party cartel' thesis and the cleavage theory offer alternative explanations of why parliamentary actors might 'neglect' the content of EU proposals during the scrutiny process in the post-Lisbon political environment. The 'party cartel' thesis focuses on the transformation of national party systems, while the cleavage theory addresses the role of EU issues in structuring political competition.

This chapter assesses the abovementioned expectations about the behaviour of parliamentary actors, drawing on the data from the parliaments of Sweden, the Czech Republic and Romania. Figure 2 shows how the opportunity structure of these parliaments looks like in the aftermath of the Lisbon Treaty. Although the formal scrutiny rules in the Swedish, Czech and Romanian parliaments have remained rather distinct, a number of common trends can be discerned.

The mode of inter-party relations has a crucial impact on the way national parliaments make use of the new opportunity structure. In contrast to the adversarial mode of inter-party relations, the consensual mode allows for a greater involvement of opposition in the scrutiny process as well as encourages more active participation of parliamentary administrators. Minority governments are conducive to the development of such consensus-seeking parliamentary practices and encourage comprehensive assessment of EU proposals. Moreover, burden-sharing and cooperation between the European Affairs Committees and sectoral committees are essential as otherwise a parliament's capacity for scrutinizing complicated technical issues becomes impaired. 


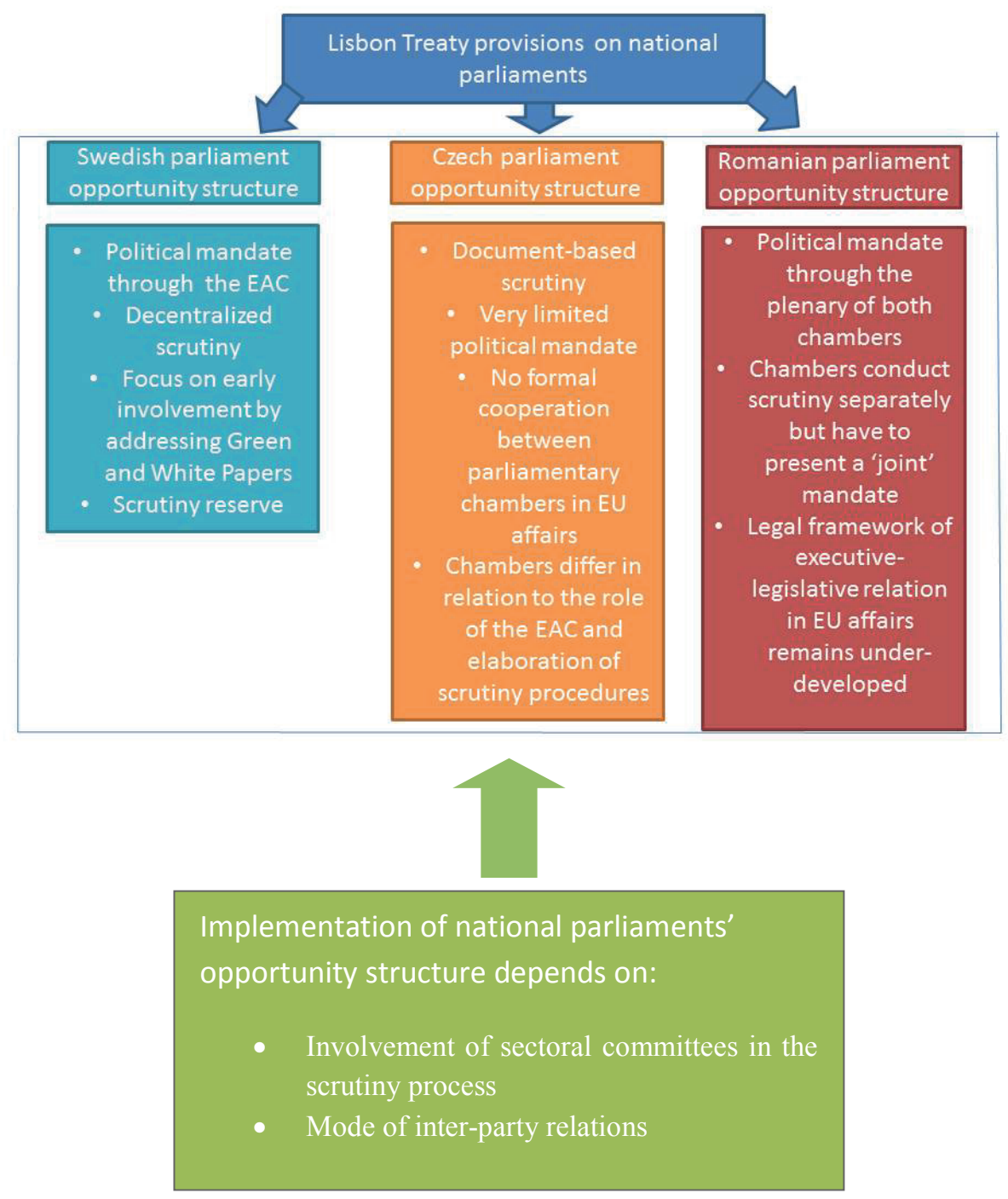

Figure 2: Opportunity structure of the Swedish, Czech and Romanian parliaments in the aftermath of the Lisbon Treaty

Political parties have a crucial impact on the way national parliaments adapt to the new 'opportunity structure', but their influence has been somewhat 'negative'. This means that instead of actively shaping parliamentary debates on EU affairs, political parties have focused on limiting the abilities of parliamentary administrators and committees to independently participate in the scrutiny process. Political parties reduced the influence of parliamentary administrators by limiting the demand for EU expertise and largely pre-empted independent committee input into the scrutiny process by nominating sec- 
ond-rate politicians as committee members. This chapter also shows that during the scrutiny process in the Czech, Swedish and Romanian parliaments, both government and opposition parties primarily focused on the division of competences between the EU and member states and largely disregarded the actual content of EU proposals. This 'neglect' of the content of EU proposals by political parties can be explained by the limited salience of EU issues in structuring political cleavages.

\subsection{Domestic rules of procedure, material and temporal constraints}

The provisions of the Lisbon Treaty provide national parliaments with new instruments for addressing EU affairs, such as controlling the compliance of EU legislative initiatives with the principle of subsidiarity or addressing the Court of Justice of the European Union. The Lisbon Treaty, however, does not prescribe any template for conducting domestic parliamentary scrutiny of EU affairs. The new Treaty provisions had to be 'interpreted' by national parliamentary actors in order to reform their rules of procedure or set up new parliamentary practices.

The parliaments of the Czech Republic, Romania and Sweden have all been engaged in the development of new scrutiny rules. The Czech Parliament acquired a right to provide a mandate to the national government in a limited number of areas. The Romanian Parliament was finally able to adopt a law on executive-legislative cooperation on EU affairs after seven years of negotiations. The Swedish Parliament also engaged in an assessment of its scrutiny procedures within the framework of the so-called EUMOT working group, although its suggestions were not adopted. None of these reforms were prescribed by the EU Treaties. National parliaments explored for themselves the options of transposing and 'interpreting' the provisions of the Lisbon Treaty.

Nonetheless, these reforms have not led to a comprehensive overhaul of scrutiny systems in any of the national parliaments considered. Sweden continues to rely on a decentralized system, focusing on integrating standing committees into the scrutiny process, although in the Riksdag only the European Affairs Committee (EAC) has the right to issue politically binding voting instructions in relation to the government's negotiation position in the Council of Ministers. However, close cooperation between the EAC and sectoral committees enables the Riksdag to pass a large number of reasoned opinions. Without systematically integrating sectoral committees into the scrutiny process the Riksdag would not have been able to achieve this. Still, the radical suggestions by the EUMOT working group to abolish the EAC and delegate mandating rights to standing committees have not been adopted. The Czech Parliament still largely relies on a document-based scrutiny system ${ }^{246}$, although both chambers are willing to use the new mandating rules whenever possible in order to set the precedent for comprehensive parliamentary involvement in defining national policy towards the EU. Although Romania has adopted a law on executive-legislative cooperation on EU affairs, the docu-

${ }^{246}$ See Chapter 1 for the distinction between mandating and document-based systems. 
ment lacks clarity, ${ }^{247}$ which leaves room for doubt about the ability of the Romanian Parliament to effectively participate in the scrutiny of EU affairs.

It could be argued that despite the adoption of new formal rules, parliamentary scrutiny systems in Sweden, the Czech Republic and Romania have remained 'lockedin' and evolved in a somewhat path-dependent manner. Convergence towards a distinct model of parliamentary scrutiny has not taken place. Although EU affairs are becoming increasingly 'mainstreamed' in the work of national parliaments (Gattermann, Högenauer and Huff 2013) ${ }^{248}$, the latter continue to conduct scrutiny largely according to their national contexts and traditions. The new 'opportunity structure' does not seem to have homogenized scrutiny rules or pushed the abovementioned parliaments to consciously emulate the 'best practices' of each other.

It is important to note that while, in theory, addressing non-legislative EU documents such as Green Papers and White Papers, exactly as the Swedish Riksdag does, can ensure the 'early involvement' of national parliaments in the EU policymaking process and secure greater leverage for them, in practice, this does not seem to happen. Respondents did acknowledge that addressing non-legislative EU documents can help acquaint MPs with EU affairs, but no respondent provided clear examples of a situation in which addressing Green Papers or White Papers had helped shape the policymaking process at the EU level according to the preferences of national parliamentary actors.

Of the three national parliaments analysed, the European Affairs Committee (EAC) in the Riksdag is arguably the strongest in terms of formal provisions as it can issue a mandate without convening a plenary session. In the bicameral parliaments of the Czech Republic and Romania, the EACs in the lower chambers do not need to have their resolutions confirmed by the plenary ${ }^{249}$. The upper chambers of the Czech and Romanian parliaments generally submit the resolutions of their respective EACs to a plenary vote. In practice, however, it is not just the formal competences of the EACs that matter but also the involvement of other sectoral committees in the scrutiny process (Raunio and Wiberg 2010). While the Riksdag scrutiny system relies on close cooperation between the EAC and sectoral committees, the parliaments of the Czech Republic and Romania find it very challenging to establish regular contacts between these fora. In fact in the Swedish Riksdag it is the sectoral committees who conduct scrutiny, while the EAC gets involved when a negotiation mandate has to be issued. In principle systematic cooperation between EACs and sectoral committees is paramount for a comprehensive assessment of EU proposals as members of a European Affairs Committee do not nec-

\footnotetext{
${ }^{247}$ For example, the status of a mandate issued to the government as well as criteria for selecting the opinion of the upper or the lower chamber as the basis for a mandate remain unclear.

248 According to Gattermann, Högenauer and Huff (2013) 'mainstreaming' implies that the scrutiny of EU affairs is increasingly treated as a normal routine element of a parliament's work in terms of internal procedures and the involvement of standing committees.

${ }^{249}$ In the Czech Chamber of Deputies the EAC decides itself if it wants to submit a resolution to a plenary vote, while in the Romanian Chamber of Deputies such a decision is made by the Standing Bureau of the lower chamber. In both cases the submission of resolutions to a plenary vote does not happen very often.
} 
essarily have enough technical knowledge and expertise to analyse EU documents on their own. In fact, even in the Riksdag closer ties between the EACs and standing committees were often resisted, but the formal obligation on sectoral committees to conduct subsidiarity control and the recent practice of regular reporting between the EAC and standing committees have made this cooperation stronger. Ultimately, the involvement of sectoral committees in the scrutiny process is one of the key factors that determine how national parliaments adapt to the new 'opportunity structure'. Without regular contacts between the European Affairs Committees and sectoral committees, national parliaments are not able to comprehensively integrate technical information and the opinions of different actors into the scrutiny process.

Taking the ability of a parliament to gather and analyse information without recourse to the government's resources as a measure of its independence, it can be said that in the new 'opportunity structure' neither strong (Sweden) nor relatively weak parliaments (the Czech Republic, Romania) have been able to obtain greater freedom of action. Parliaments have been granted access to EU information, but even the Swedish Riksdag cannot conduct analysis of EU proposals without using the government's memos. The reason for this is not a legal obligation to conduct scrutiny on the basis of these documents, but the fact that the Swedish Parliament is simply unable to analyse EU proposals without the help of government explanatory memoranda. In the Czech Parliament, initiatives to start the scrutiny process without recourse to governmental explanatory memoranda have also been dropped due to similar practical considerations. The Romanian Parliament is unable to carry out assessments of EU proposals independently, but in contrast to the Swedish and Czech parliaments it faces an additional challenge. While in Sweden and the Czech Republic the majority of government memoranda are delivered automatically to the national parliament, the new Romanian law on executive-legislative cooperation envisages that the government will send these memos only at the request of parliament. This will significantly diminish the ability of the Romanian Parliament to participate in the scrutiny process. Although there is a clear difference between the capacities of the Swedish, Czech and Romanian parliaments to gather and analyse information, those of Sweden and the Czech Republic ${ }^{250}$ being more advanced than those of Romania, none of these parliaments are able to assess EU documents without the assistance of their respective national governments.

In general, national parliaments have been able to address the 'material and temporal constraints' of adopting the Lisbon Treaty provisions and reforming domestic scrutiny rules. Nonetheless, both strong and weak parliaments face challenges, for example, in terms of managing the flow of EU documents. The majority of respondents, however, including MPs, parliamentary staff and experts, considered that administrative

\footnotetext{
${ }^{250}$ It is a matter for debate whether the Riksdag or the Czech Parliament have better analytical services. Both chambers of the Czech Parliament have access to a large number of information databases (shared with the government) and dedicated administrative units which provide expertise on EU affairs. The Riksdag, however, seems to obtain government memoranda much quicker and they seem to be of a somewhat better quality than those from the Czech Government.
} 
support for the scrutiny process in their respective parliaments is generally adequate. A number of mechanisms have been put in place to overcome 'material and temporal constraints'. The Swedish Parliament tackles this challenge by way of close cooperation between the staff of the EAC and the standing committees, which enables it to share the burden of analysing highly technical issues. The Czech Parliament takes advantage of informal social networks that cross-cut the legislative and executive branches, as well as by sharing a number of databases with the government. The Romanian Parliament relies on the presence of several key staff members who have worked on EU issues almost from the original set-up of the scrutiny system, and hence possess 'institutional memory'. It is the administrative support of the scrutiny system in Romania that faces the greatest challenges in comparison with those of the Swedish or Romanian parliaments. It remains unclear whether the Romanian Parliament will be able to attract new, highly-skilled staff to assist and eventually replace the current members of the parliamentary administration. Moreover, doubts have been raised about the transparency of the hiring procedures in the Romanian Parliament. There is also no clear division of competences in dealing with the EU agenda between different departments of Romania's parliamentary administration, which provokes turf wars and hampers coordination during the scrutiny process.

\subsection{Parliamentary administrators}

Because the new 'opportunity structure' creates more demand for information and expertise on EU affairs, it had been thought that parliamentary staff might obtain increased political leverage in terms of shaping the outcomes of the scrutiny process. In practice, however, the abilities of parliamentary administrators to influence the rules of procedure and scrutiny outcomes according to their own interests remain limited.

For example, suggestions by the Riksdag staff, enshrined in the EUMOT working group report, to reform the Swedish scrutiny system were rejected by politicians. The ideas by Romanian parliamentary administrators to develop the new law on executivelegislative cooperation on EU affairs on the basis of technical negotiations between government and parliamentary staff ${ }^{251}$ were rejected by MPs. Moreover, the proposal launched by Romanian parliamentary staff to introduce exclusive membership of the EACs is in practice ignored by Romanian MPs, even though it has been formally adopted. Even in the Czech case, where parliamentary staff initiated and created a framework for the MP-MEP dialogue, the actual meetings are more focused on networking rather than policy coordination, contrary to what the staff members envisaged.

According to the Weberian tradition, bureaucrats are considered politically neutral and their role is limited to the execution of purely technical tasks (Barberis 2011). Others (for example, Bendor and Moe 1989; Moe 2005; Gailmard and Patty 2007) have

\footnotetext{
${ }^{251}$ As opposed to 'political' negotiations, which would involve high-profile MPs and members of the political elite.
} 
argued that administrators develop their own policy preferences and cannot remain 'neutral' in the Weberian sense. Christiansen, Högenauer and Neuhold (2014) suggest that the crucial role of administrative staff in selecting EU documents for scrutiny and providing expertise grants them a measure of political influence. In practice, however, members of parliamentary staff do not seem to have used these powers to systematically influence the outcome of the scrutiny process or promote a distinct political agenda. At least during the assessment of the Green Paper on pensions and the Proposal for a directive on seasonal labour migrants, parliamentary administrators have not tried to promote a specific outcome of the scrutiny process. Parliamentary administrators do not challenge the right of MPs to make a final decision on the outcome of the scrutiny process. On the other hand, parliamentary administrators are more concerned about making sure that the position of parliament is known and taken into account by other political actors. For example, the regular dialogue on EU issues between parliamentary and government staff in the Czech Republic is meant to serve this goal. Clearly, parliamentary administrators attempt to secure the widest possible sphere of competence for their respective institutions, while the distinct outcome of a particular scrutiny process may not be of the highest priority to them. A similar pattern can be observed in the European Parliament, where, according to Dobbels and Neuhold (2013) as well as Neuhold and Dobbels (2014), the staff do not simply carry out administrative tasks but focus on promoting the position of the European Parliament in inter-institutional bargaining.

The interview data show no traces of Swedish, Romanian or Czech parliamentary staff lobbying for a specific result in a scrutiny procedure. Parliamentary staff can try to increase the awareness of MPs by highlighting controversial issues, or try to connect the content of an EU proposal with an ongoing domestic debate, as Czech parliamentary staff tried to do during the scrutiny of the Green Paper. Nonetheless, it is the MPs who have the power of veto on accepting or rejecting the suggestions of parliamentary staff. In fact, administrators from strong (Sweden) and weak (Czech Republic, Romania) parliaments have repeatedly argued that lack of interest from MPs in EU affairs creates little demand for in-depth analysis of EU proposals and constitutes one of the greatest challenges for the scrutiny process.

Parliamentary staff avoid carrying out distinctly political tasks which can affect scrutiny outcomes. For example, Riksdag staff are often tasked with 'transposing' partisan opinions on EU issues for draft resolutions before committee negotiations begin. The problem is that Swedish political parties may not necessarily have an official position on a specific technical detail related to EU affairs. In theory, this makes the parliamentary staff a powerful agenda-setter as it can frame subsequent committee discussions. In practice, however, the Riksdag staff either draft these positions in a broad, uncontroversial manner, so that they would be acceptable to all MPs, or demand additional guidance from political parties.

Occasionally, the involvement of political parties in the work of parliamentary administrators goes beyond control for the compliance of resolutions with partisan posi- 
tions. There have been several attempts to politicize parliamentary staff in the Czech and Romanian parliaments, ${ }^{252}$ either by the nomination of party affiliates to posts in the parliamentary administration or through demands to provide analysis that 'ideologically conforms' to specific partisan positions. These measures pre-empt or at least limit the independent involvement of parliamentary staff in the scrutiny process. Politicization has been promoted by political parties and serves as a vehicle to control the parliamentary administration in situations of acute inter-party rivalry.

Ultimately, parliamentary administrators have found it difficult to exert greater political leverage on scrutiny outcomes in the new 'opportunity structure'. It comes as no surprise that political parties have a power of veto over the decisions and initiatives of parliamentary staff. What is noteworthy is that MPs in the parliaments of Sweden, the Czech Republic and Romania have repeatedly used these powers against the suggestions of parliamentary administrators related either to scrutiny procedure reform or the outcomes of assessments of EU proposals.

\subsection{Parliamentary committees}

It has been suggested that the political influence of European Affairs Committees could increase in the new opportunity structure', as their role as hubs of expertise and centres of coordination between various political parties is likely to grow. It is believed that the need to coordinate the actions of various political parties in the highly technical domain of EU affairs creates conditions for cross-party dialogue and allows EACs to escape strict partisan control and acquire an independent political profile (Shepsle and Weingast 1981, Krehbiel 1991). In practice, however, information from the parliaments of Sweden, the Czech Republic and Romania shows that the behaviour of the EACs in the new 'opportunity structure' is still determined by the political parties. This can be explained by several factors.

First, nomination to EACs is controlled by the political parties. This is due to the fact that neither in the strong Riksdag, nor in the less influential parliaments of the Czech Republic and Romania does the EAC rank high in the internal parliamentary hierarchy.

For example, in 2008-2009 the Czech ruling parties did not want to renegotiate the coalition agreement in order to prevent the position of EAC chair in the lower chamber remaining empty. Clearly, chairing the EAC was considered much less prestigious than chairing the Budget or Foreign Affairs Committee. As service on an EAC does not seem to increase the chances of re-election and provides only limited media coverage, there are few MPs who want to specialize in EU affairs and thus voluntarily select service on this committee. In general, political parties nominate second-rate MPs to the European

\footnotetext{
${ }^{252}$ Drawing on the definition developed by Peters and Pierre (2004), it could be argued that politicization of parliamentary administrators means that their activities are not conducted on the basis of serving the general interests of a parliament but are focused on supporting the position of a specific parliamentary party.
} 
Affairs Committees. These MPs cannot afford to deviate from the respective party lines, as their career prospects would be at risk. As a result, cross-party cooperation between MPs remains difficult and parliamentary committees find it hard to develop a political profile that is not completely dependent on the partisan affiliation of MPs. Ultimately, by strategically placing MPs who cannot afford to deviate from partisan ideologies on to the EACs, political parties pre-empt independent committee involvement in the scrutiny process.

Second, as the example of the Swedish Riksdag shows, European Affairs Committees can simply formalize inter-party agreements that have already been reached in other standing committees, leaving little specific 'EAC input' into the scrutiny process. Moreover, the fact that in the Czech Senate resolutions of the EAC, which was chaired by a member of the opposition, were constantly controlled in the plenary for compliance with the views of the majority clearly shows that the outcomes of deliberations in the EAC are determined by the partisan composition of parliament.

As noted above, regular contacts between EACs and sectoral committees are essential for effective scrutiny. In the Czech and Romanian parliaments, however, such contacts are ad hoc. This makes information exchange more difficult and hinders the development of a distinct as in the absence of regular formal committee contacts, communication starts to run primarily along partisan lines.

Within the new 'opportunity structure' political parties have acted as 'negative' agenda-setters for parliamentary committees. MPs have not tried to directly 'control' parliamentary committees by drawing debates towards specific policy outcomes in the domain of EU affairs. Instead, political parties in Sweden, the Czech Republic and Romania have focused primarily on pre-empting independent committee participation in the scrutiny process, for example, by controlling the nomination procedure for committee membership. Nonetheless, in order to effectively adapt to the new post-Lisbon environment, close collaboration between the EACs and sectoral committees has to be established, although as Gattermann et al. (2013) argue, one has to "expect variation both within and across national parliaments" in terms of involving sectoral committees in the scrutiny of EU affairs.

\subsection{Political parties}

In relation to the behaviour of political parties in the new 'opportunity structure' the thesis addresses two expectations. The first is that although all political parties will start addressing EU issues, it is the opposition that will be most active in using the postLisbon environment to put pressure on the governing parties. The second is that the opposition will be more active in using the new 'opportunity structure' in countries with minority governments. 
The first expectation has been only partially corroborated. Political parties representing all segments of the ideological spectrum are involved in the scrutiny process, but during assessment of the Green Paper on pensions and the Proposal for a directive on seasonal migrants both governing and opposition parties focused on the division of competences between the EU and their respective national governments, defending the domestic status quo against further interference from the European Union. This happened irrespective of whether the political parties are Eurosceptic or pro-European. In fact, the argument of Batory (2009), that "soft Eurosceptic rhetoric or Eurpohilia say little or nothing about a party's willingness or ability to make use of opportunities offered by the EU level of the political game", seems to hold true at least in the abovementioned cases.

The content of both the Green Paper and the Proposal for a directive on seasonal migrants was largely ignored during the scrutiny process, although their assessment could bring both governing and opposition parties electoral benefits and help them bring national regulation in the pension and labour migration sectors closer to their preferences. For example, the Swedish Social Democrats, which are part of the opposition, have not used the Proposal for a directive on seasonal migrants to reintroduce labour market tests ${ }^{253}$ for third country workers, which would be popular among their trade union supporters. Nor did the Czech parties use the Green Paper on pensions as a reference point in the ongoing national pension system reform, although both supporters and opponents of the reform could use elements of the Green Paper on pensions to strengthen their positions.

Although the analysis of the Green Paper on pensions and the Proposal for a directive on seasonal labour migrants did not trigger any major conflicts between the governing parties and the opposition, there is evidence that allows the suggestion that opposition parties are indeed more interested in the new 'opportunity structure' than the governing parties. Their interest may relate not so much to achieving a specific policy goal but instead to developing structural mechanisms that would put pressure on the government in the future. For example, in the aftermath of the Lisbon Treaty the opposition Swedish Social Democrats launched a dialogue with Swedish Social Democrat MEPs that would help compensate for the weaker position of Social Democrats in the national arena. When the Czech Social Democrats were in opposition they complained directly to the European Commission about the alleged unwillingness of the national government to consult them on matters related to the 'European Semester'. Opposition parties have been the key actors behind demands to grant the Romanian Parliament the right to issue the national government with a politically binding mandate on negotiations at the EU level. In principle, opposition parties in Sweden, Czech Republic and Romania have used the new 'opportunity structure' to exert pressure on the government. In contrast to the opposition parties, the governing parties of these countries do not

\footnotetext{
${ }^{253}$ Tests that are meant to validate a claim that a given third country worker can be hired as the national or EU labour market cannot satisfy the demand.
} 
seem to have actively used the new 'opportunity structure', for example to reassess domestic scrutiny procedures.

In general the role of the opposition in the scrutiny process seems to be greater in countries with a minority government, like Sweden. Respondents from the Riksdag mentioned that in practice the governing centre-right coalition tries to secure the support of at least some opposition parties in informal negotiations and, as a result, obtain a majority. On the other hand, the opposition often finds it difficult to block the government's initiatives as this requires the coordination of ideologically very different parties such as the Greens, the Social Democrats, the Left Party and the Sweden Democrats (a radical right party). Practice in the Swedish Riksdag is focused on reaching consensus, which becomes increasingly important when the government is formed by a minority coalition. Although inter-party agreements may be informal and concluded outside of the parliamentary arena, this practice provides the opposition with a stable channel of influence over the government's policies. The systematic involvement of opposition and minority government in Sweden also contributes to the fact that the Riksdag is so active in using the Early Warning System. Constant negotiations between the ruling and opposition parties that are necessary for building parliamentary majorities make a wider range of opinions politically acceptable. This makes it easier to draft and adopt reasoned opinions.

In contrast to the Swedish example, the parliaments of the Czech Republic and Romania do not allow the opposition a comparable measure of influence over EU affairs. This is not only because the governments of the Czech Republic and Romania are supported by parliamentary majorities. These parliaments do not seem to have advanced mechanisms for establishing consensus, and acute conflicts between the parliamentary majority and the opposition are common. These conflicts, however, do not relate to fundamental differences in approach to the EU, but are more a reflection of a power struggle and political bargaining between various party groups. For example, in 20102013 the upper chamber of the Czech Parliament was controlled by the opposition, which often prevented the ruling centre-right parties from proposing issues for the plenary agenda, using this as a symbol of power vis-à-vis the government. The Romanian Parliament is also wrought with conflicts due to the constantly changing governing and opposition coalitions. Ultimately, the involvement of the opposition does not automatically make the scrutiny process more effective. What matters is the availability of consensus-building mechanisms within the parliamentary arena. Otherwise, the scrutiny process will reflect the 'traditional' power-sharing debates, with the opinion of the parliamentary majority prevailing, which can have a negative effect on the ability of parliament to comprehensively address EU issues.

It can be argued that in the new 'opportunity structure' political parties have been able to maintain substantial leverage over the conduct of the scrutiny process and to have limited the ability of other actors, such as parliamentary administrators and com- 
mittees, to independently shape scrutiny outcomes. This has been observed in the parliaments of Sweden, the Czech Republic and Romania.

First, political parties have repeatedly used their right to veto any proposals by parliamentary staff that do not suit their interests, regardless of whether these suggestions relate to procedural rules or to the content of EU initiatives. Moreover, in the parliaments of the Czech Republic and Romania there have been attempts to put parliamentary staff under direct partisan control either through the nomination of party affiliates to administrative posts or by pressure to provide analysis that is based on the view of the majority in a given chamber.

Second, political parties control nomination and information exchange between the European Affairs Committees and the sectoral committees. This diminishes the opportunities for cross-party cooperation and the development of a distinct 'committee input' - as opposed to 'partisan input' - into the scrutiny process. The fact that EACs are normally staffed by very few 'political heavyweights' means that most committee members would be likely to vote strictly in accordance with the party line in order to secure career advancement.

Third, political parties have controlled the debate over the reform of scrutiny rules in the aftermath of the Lisbon Treaty. For example, the report of the EUMOT working group in the Swedish Riksdag was not adopted precisely because the two largest governing and opposition parties feared that the envisaged reforms would harm their ability to control the EU agenda in the national parliament. Debates over the Romanian law on executive-legislative cooperation provide another example of how political parties control procedural scrutiny rules. Although the opposition initially favoured the adoption of the law and lobbied for it, the party has apparently not used its control over the post of EAC chair to actively promote its opinion. Some members of the opposition seem to have changed their opinion about the need to adopt this law in exchange for other 'benefits', according to Romanian respondents, which has undermined the existence of a stable parliamentary majority in support of the law. Moreover, attempts to declare the law unconstitutional have come from political parties that supported the president, in an attempt to limit control over his actions in EU affairs.

In sum, the pattern of inter-party relations, together with the involvement of sectoral committees in the scrutiny of EU affairs are crucial factors that determine the way in which national parliaments adapt to the new 'opportunity structure'. Where mechanisms for building consensus are in place, the opposition will have a stronger influence over the scrutiny process than in systems with acute inter-party rivalry. Consensusorientated inter-party dialogue is also more conducive to an expert-based assessment of EU proposals. In a situation of acute inter-party rivalry, the scrutiny of EU affairs is likely to reflect the power struggles between the majority and the opposition rather than a comprehensive assessment of EU proposals. 


\subsection{Reactions of parliamentary actors to the new opportunity structure}

Arguably, 'voice', defined as an attempt to promote the views of parliamentary actors through negotiations, is the key type of reaction by parliamentary actors to the new 'opportunity structure' in the parliaments of Sweden, the Czech Republic and Romania. 'Voice', however, is primarily linked to the behaviour of political parties as the activities of parliamentary staff are controlled by MPs and European Affairs Committees primarily function according to partisan logic. 'Voice', defined as an attempt by parliamentary actors to promote their views and shape the outcome of the scrutiny process through negotiations, relates both to cases in which the design of the scrutiny procedure is at stake, for example the report of the EUMOT working group in the Riksdag, and to the assessment of specific policy proposals initiated by the EU. In the parliaments of Sweden, Czech Republic and Romania the design of the scrutiny procedure was a result of negotiations between parliamentary administrators and political parties. The political actors were 'voicing' different ideas on how the amended procedural rules should look like and engaged in bargaining. The same observation is valid for the scrutiny of specific policy proposals: parliamentary actors engage in negotiations (sometimes informal negotiations) over EU documents or mandates that have to be issued to the domestic executives. It should be kept in mind that 'voice' often has little to do with the saliency of EU affairs. Discussion of EU affairs seems to matter primarily within the wider logic of the power struggles between parliamentary majority and opposition, not due to the inherent importance of EU issues. The details of how voice is used depend on the involvement of sectoral committees and the general pattern of inter-party relations. The involvement of sectoral committees defines the scope of information that can be used during negotiations. The pattern of inter-party relations determines whether cooperation or conflict between parties will be the main method of expressing the parties' interest.

Although the Lisbon Treaty provides conditions for greater inter-parliamentary cooperation as well as contacts between national parliaments and EU-level institutions, 'threat of issue exit' is not consistently used to exert influence on national governments. As the examples from Sweden and the Czech Republic demonstrate, opposition parties occasionally attempt to exploit contacts with EU institutions and MEPs as an instrument to put pressure on their respective governments. However, the occasions when 'threat of issue exit' is used remain limited and its ability to change governmental policies is questionable. It is noteworthy that during the scrutiny of the Green Paper on pensions and the Proposal for a directive on seasonal labour migrants neither rapporteurs and shadow rapporteurs in the European Parliament, nor representatives of the Brusselsbased stakeholders, nor the relevant DGs of the European Commission were consulted by any actors from the parliaments of Sweden, the Czech Republic or Romania. No parliamentary actors, irrespective of their attitude to the abovementioned EU proposals, deemed it important to acquire political allies at the EU level in these particular cases. Thus far, there are few signs that the 'threat of issue exit' has been used to change the 
content of EU proposals. This does not mean, however, that channels such as MP-MEP contacts or inter-parliamentary cooperation will not be used for the 'threat of issue exit' in the future. Although more research is needed, the fact that the Czech Senate attempted to establish a coalition of national parliaments against the Proposal for a directive on seasonal labour migrants could imply that inter-parliamentary cooperation is used not only by opposition parties to put pressure on the government, but also by national parliamentary actors as an instrument to limit the spread of EU competences ${ }^{254}$.

Assessment of parliamentary practice in Sweden, the Czech Republic and Romania also provides evidence that the new 'opportunity structure' can be 'neglected' to some extent in the sense that the scrutiny process largely disregards the content of EU proposals, although the new political environment provides parliamentary actors with many options to address the content of EU policy proposals and obtain political benefits ${ }^{255}$. Instead, the scrutiny process addresses primarily the division of competences between the EU and member states. This similarity between strong (Sweden) and relatively weak (Czech Republic, Romania) parliaments in terms of scrutiny focus is especially interesting due to the fact that there is little convergence among national scrutiny procedures within the new 'opportunity structure'. Although the topics of pensions policy and labour migration are salient within the domestic political debate, political parties were very reluctant to compare the policy solutions proposed by the EU with national approaches to these policy sectors. The views of different political parties on the reform of pension and labour migration systems can be articulated within the socio-economic cleavage. In theory, EU proposals in these policy domains can also be articulated within the framework of the 'traditional' left-right divide. As a result, EU issues could be integrated into the existing political cleavages and play a greater role in structuring partisan conflicts $^{256}$. In practice, irrespective of their pro-European or Eurosceptic position or majority and opposition status, during the scrutiny of the Green Paper on pensions and the Proposal for a directive on seasonal labour migrants, all political parties were primarily concerned with subsidiarity issues. This does not mean that MPs disregard the content of EU proposals in each and every scrutiny case. It does demonstrate, however, that even when electoral benefits can be drawn from in-depth assessment of the content of EU documents, political parties may wish not to use this opportunity but to limit the inter-party debate to the issue of subsidiarity. 'Neglect' can also mean a situation in which political parties consciously postpone the adoption of new procedural rules related to the scrutiny of EU affairs, as was the case in Romania, unwilling to use the new 'opportunity structure' to enhance parliamentary powers. It should be stressed, however, that 'neglect' does not mean lack of activity on EU affairs. For example, the Swedish

\footnotetext{
${ }^{254}$ National parliaments also cooperated during the scrutiny of the so-called Monti II Regulation.

${ }^{255}$ See Chapter 2 (p.40) for the definition of 'neglect'

${ }^{256}$ According to Green-Pedersen (2012) new topics, for example EU issues, can be mobilized primarily if they fit the 'traditional' cleavage structure, for example the 'left-right' divide. The EU proposals analysed in this thesis directly addressed these 'left-right' issues (pensions and labour migration), which could make it easier for national parliaments to analyse the content of EU documents during scrutiny.
} 
Parliament is one of the most active in EU affairs, but in the scrutiny process it exhibits a tendency to concentrate on the division of competences - not the content of EU proposals. Although subsidiarity control and the Early Warning System are central elements of the Lisbon Treaty, its impact on the scrutiny process cannot be reduced to control over the division of competences. Unless national parliaments address the content and policy implications of EU proposals they miss the chance to connect EU issues to the domestic political debate and neglect the instruments of policy influence that are available to them.

Ultimately, political parties are the key group of parliamentary actors to whom the notions of 'voice', 'threat of issue exit' and 'neglect' can be applied. Neither parliamentary administrators nor committees seem able to contribute 'independently' to the scrutiny process. Political parties are able to control the 'input' of both administrators and committees into the scrutiny process through exercising the veto right over any procedural changes, controlling information exchange between committees and nomination to the EACs. As a result political parties emerge as the key type of parliamentary actor that shapes the implementation of the 'opportunity structure'. The reactions of other parliamentary actors to the new 'opportunity structure' are ultimately framed by political parties. .

\subsection{Explaining the behaviour of political parties through party cartel thesis and cleavage theory ${ }^{257}$}

According to the 'party cartel' thesis (Katz and Mair 1995, 2009), neglect of the content of EU proposals by political parties occurs as a result of a specific transformation of national party systems. The 'cartel model' implies that political parties avoid mobilizing the electorate on new issues, for example EU affairs, and develop a practice of informal cooperation between governing and opposition parties. As a result, party systems with strong cartelization characteristics 'neglect' EU issues, which will be addressed only by marginal parties not included in the cartel. The 'cleavage theory' focuses instead on the role of EU issues in inter-party competition. EU topics may not be considered by political parties an important 'political cleavage', so MPs will be likely to 'neglect' the content of EU proposals in the parliamentary debate.

The evidence about the extent of cartelization in the Swedish party system is mixed. At first glance, it could be argued that the Swedish case supports the doubts of Kitschelt (2000) about the emphasis that 'party cartel' thesis puts on the autonomy of the party leadership. For example, Blyth and Katz (2005, p.52) argue that in the 1990s the leadership of both centre-right and centre-left parties in Sweden had to give way to the demands of party members during social security system reform. Increased vote switching by the traditional electorate of the Social Democrats to the Green Party and the Left Party does not support the idea of political parties cooperating closely in order

\footnotetext{
${ }^{257}$ For a detailed discussion of the party cartel thesis and 'cleavage' theory see chapters 1 and 2.
} 
to curb electoral volatility. In addition, the reliance of Swedish parties on public funding may not necessarily be a sign of greater cartelization of the party system. In the Swedish case, according to Vignaux (2008), the dependency of political parties on public funding is something of a historical heritage as this practice dates back to $1960 \mathrm{~s}$.

There are other factors which suggest a high level of collusion and informal cooperation between Swedish political parties, fully in line with the party cartel thesis. For example, the practice of 'contract parliamentarianism' (Bale and Bergman 2006; Bergman and Bolin 2011) can be considered a proxy for party system cartelization in Sweden. This practice involves a written contract that commits parties to collaboration on specific topics. Such cooperation took place in both left wing (for example, the socalled '121 Point agreement') and right wing political parties (Christiansen and Damgaard 2008, p.56-58; Isberg 2011). Indirect evidence in support of the cartelization thesis could be the fact that Swedish political parties exhibit a very high rate of internal cohesion, according to Willumsen and Öhberg (2012). They claim that MPs representing the governing coalition rarely deviate from the party line. Nonetheless, it should be acknowledged that the alleged lack of internal partisan divisions - or the willingness to downplay them - cannot be considered sufficient evidence for the party cartel thesis.

In contrast to the 'party cartel' thesis, the evidence for an 'EU cleavage' in Sweden appears to be much stronger. It should be noted, however, that most of the evidence points to the fact that EU issues play only a limited role in partisan contestation. On the presence of an 'EU cleavage', Aylott (2002) claims that political leaders have tried to isolate EU issues from intra-party discussion, providing examples from the Swedish Social Democratic Party. Evidence from the interviews also suggests that the EU agenda is somewhat marginalized in inter-party debates. As a former member of the Riksdag (S39) claimed, "you do not talk about the EU. We want to be in the EU but do not talk about it because people might have another opinion....The EU does not seem to be a big deal, it is treated as a "natural thing". Except for the Sweden Democrats, which are strongly Eurosceptic, and the Liberal party (strongly pro-European), Swedish political parties tend to be moderately pro-European, but in principle 'Europe' remains something of a taboo in the Swedish political discourse. EU issues are addressed but are not discussed in great detail.

Of all the Swedish parties, according to a Swedish academic expert (S20), it is the Social Democratic Party that has experienced the strongest internal divisions related to EU issues, so they are likely to avoid mobilizing their electorate on these topics. Johansson and Raunio (2011) as well as experts from the Swedish think tank SIEPS (S17) argue that although EU issues have become accepted and legitimized in the Swedish political discourse, these attitudes go hand in hand with a strong sense of the need to keep the European Union's influence on Swedish internal affairs to a minimum. It is important to note that the general election of 2010 was largely silent on EU issues. According to Aylott (2010), the fact that the left-wing parties and the Greens were forced to for a loose coalition in order to contest the centre-right parties in the 2010 parliamen- 
tary elections made it necessary to disregard the differences in their approaches to the EU. As a result, EU topics were marginalized.

The number of staff dealing with EU affairs in the central offices of the political parties (Poguntke et al. 2007) could be considered a proxy for the salience of the EU cleavage in inter-party competition. If EU issues were an important element of electoral competition, political parties would require a dedicated body of experts to help develop party programmes and action in relation to the EU. Although it proved difficult to establish contact with party experts on EU affairs, it can be argued that the internal administrations of the Swedish political parties do not consider EU issues to be among their priorities. A former staff member of a centre-right party noted that: "Administrative support in EU affairs among Swedish parties depends on party size. It is not the saliency of EU issues but the amount of money or resources that parties have that determines the amount of staff dealing with the EU. Hence, big parties like the Moderates or the Social Democrats have more staff but they do not prioritize EU issues more than other parties" (S40). It is noteworthy that currently, according to a staff member of the Swedish Social Democratic Party, the central party office has only four staff members dealing with EU issues, two of whom also work on the foreign affairs portfolio (S11b).

It is difficult to say whether this refusal to address EU issues is a conscious strategy of political parties or a reflection of public apathy, but it seems safe to assume that in the Swedish case the potential 'EU cleavage' has not stimulated MPs to address the content of EU proposals.

The Czech case also provides mixed evidence about the existence of a cartelized party system. For example, Hlousek and Pseja (2009) confirm the presence of strong cartel traits in the Czech party system, although the outcome of the 2010 general election, which resulted in two new parties joining the parliament, goes against the idea that a 'party cartel' is preventing the emergence of new political parties. The fact that the main centre-right (Civic Democratic Party, ODS) and centre-left (Social Democratic Party, ČSSD) parties received less than half the votes (Haughton et al. 2011) raises doubts about the ability of the 'old' parties to keep the electoral arena closed.

According to an expert from the Czech Institute of International relations (C29), public debate about the EU is still dominated by Eurosceptic politicians. Nonetheless, the European agenda does not seem to be a crucial element in structuring the domestic political debate, which is predominantly framed by the 'traditional' left-right cleavage and not attitudes to the EU. One of the key possible explanations for this could be the characteristics of the voter base of the two key political parties, the ČSSD and the ODS. Somewhat paradoxically, although the leadership of the ODS exhibits strong Eurosceptic sentiments, its electoral base is much more positive towards the EU than the party leadership. The ČSSD leadership adopted a more pro-European stance primarily to differentiate themselves from the ODS, but their own voters are predominantly Eurosceptic. Ultimately, within both major Czech parties there is little congruence between the opinions of the party leadership and voters' preferences on EU affairs. Political 
parties can get away with such a discrepancy between the views of the leadership and the electorate because, according to a Czech expert (C18), they "do not live by EU affairs, they do not debate them. Political parties are basically isolated from EU affairs". Czech political parties do not raise the public profile of EU issues because they try to avoid exacerbating this difference between the opinions of the party elite and the voters. Another important example of the Czech MPs' limited interest in EU affairs could be the fact that political parties hardly ever participate in the meetings arranged by a Czech NGO to bring together members of the expert community, the government and MPs in order to discuss the country's EU policy $(\mathrm{C} 1 \mathrm{~b})$.

The presence of strongly negative attitudes to the EU does not influence electoral competition. For example, the most recent general elections in 2010 were practically devoid of discussion of the EU. The limited number and competences of EU experts in the central offices of the Czech political parties reflect the relative weakness of the 'EU cleavage'. According to a Czech NGO expert (C1b), "there is not enough interest in foreign policy or EU affairs. Usually, political parties have one or two people who speak on behalf of the politicians". Representatives of the centre-right parties such as the Christian-Democrats (C33) and TOP 09 (C38) support this view. It is noteworthy that for a long time the key political parties, the Civic Democrats and the Social Democrats, saw little need to monitor the EU agenda or coordinate the activities on EU affairs of their respective MPs in the Czech Parliament (C34, C37).

Even large parties like the ODS assign very few people to address EU affairs or foreign policy. As of May 2013, the ODS had just one central office employee working on EU affairs, combining this task with a portfolio on transport policy (C34). The low numbers of party EU experts could be compensated for by access to information through the government's offices or MEPs, but arguably leaves the central party office lacking sufficient resources in the domain of EU affairs. NGO experts and parliamentary administrators argue that the ČSSD has a somewhat better pool of EU staff, but the party has only recently started to invest in this policy field (C1b, C35). As a respondent from ČSSD central office (C37) noted: "Previously the opinions of the Social Democrats in the Senate, the Chamber of Deputies and the central office about EU affairs were different. So we tried to prevent these differences....Generally, deputies were calling the central office ${ }^{258}$ and no one could answer them". All in all, evidence from the Czech Republic shows that EU issues are not perceived - intentionally or not - as an important political cleavage, while political parties are neither mobilizing their electorates on EU topics nor adapting their internal structures in anticipation of a higher saliency of EU affairs.

In the case of Romania, the data on the existence of a party cartel is not clear. There is indirect evidence that the Romanian party system is becoming cartelized as compared to other countries of Central and Eastern Europe, new parties find it much harder to get into parliament (van Biezen and Rashkova 2011). In fact, restrictive elec-

${ }^{258}$ In order to ask what the official party line is. 
toral laws have been introduced in order to curb electoral volatility, making it almost impossible, in the opinion of an expert from the Free University of Brussels (R18), for new parties to enter the Romanian political arena. The acute inter-party rivalry that is endemic to Romania seems to counter the cartelization thesis, although according to Mateescu (2010) high levels of inter-party conflict in Romania are not incompatible with cartelization. Nonetheless, Romanian parties put their trust in numbers as the country has one of the highest party membership levels, which again contradicts the cartelization thesis according to which cartelized parties do not need a lot of members in order to remain influential.

In practice Romanian political parties have largely disregarded the 'EU cleavage' in electoral competition and political debate. European topics played an important role during the pre-accession stage but since then have largely fallen out of the public discourse. As Soare (2012, p.149) argues, "EU membership has regularly been held up as a proof of the democratic quality of the political system... but the EU continues to be envisaged as 'an unidentified' political objective for national political life". According to expert opinion, "there is a strong pro-European consensus. Romanian politicians oppose Europe only when it criticizes Romania for mismanaging funds and problems with justice" (R18b). Party programmes remain elusive on EU topics and concentrate on domestic issues. Among the parliaments analysed, Romania can be considered an outlier as there are no clearly defined political cleavages ${ }^{259}$. The left and the right are hard to distinguish, while parties cannot always explain how and why specific provisions made it into their party manifestos (R14).

Research conducted by the Romanian Academic Community (SAR) in 2007 also stresses that the 'left-right' divide does not influence the position of Romanian political parties on Europe (Soare 2012, p.150). According to expert evaluations it is not policy solutions or distinct ideologies that structure the Romanian political space but personalities (R4, R14 and R15). The Romanian party system is driven by patron-client relationships and 'migration' between the political parties is high. Therefore, any clear ideological affiliations, be they left-right distinctions or attitudes to the EU, are more of a liability than an asset. As a representative of a Romanian think-tank argued, there is only a minimal ideological distinction between political parties, which almost never follow their self-proclaimed ideological lines. Party positions on the EU are by no means detailed (R21). In the opinion of a staff member of a German NGO working in Romania, there is hardly any partisan division on EU affairs because this issue is completely detached from the topics discussed in domestic politics (R3). Respondents were also rather sceptical about Romanian political parties having strong expert support on EU affairs.

In the cases of Sweden, the Czech Republic and Romania, there is no unequivocal support for the cartelization of party systems, while it is clear that the discussion of EU

\footnotetext{
${ }^{259}$ The dichotomy communist vs. anti-communist (pertaining to party traditions and history) as well as attitudes to the President Basescu seem to be the only distinctions that matter in the Romanian political landscape.
} 
topics is avoided by most political parties. In other words, 'Europe' is not articulated as a salient political cleavage, which could explain the widespread use of 'neglect' in reaction to the post-Lisbon 'opportunity structure'. The evidence presented above does not prove whether the weakness of the 'EU cleavage' is merely a reflection of the low public interest in EU affairs or a conscious strategy by political actors.

It is important to note that EU issues do not constitute an important element of inter-party competition not only in the parliaments of Sweden, the Czech Republic and Romania but also in other EU member states (Poguntke et al. 2007; Ladrech 2007). As Ladrech (2007, p.952) puts it, "national political parties continue to operate as if the EU is external to their goals and activities", which creates little demand for in-depth parliamentary scrutiny of EU affairs. This lack of interest in EU affairs can be translated into 'neglect' or shallow assessment of EU policy proposals during the parliamentary scrutiny process.

There is also a trend for party leaderships to become more autonomous from party members in defining a party's policy on EU issues (Ladrech 2012). This can be considered a sign of cartelization as, according to Katz and Mair (2009), the concentration of power in the hands of the party leadership as well as restraining the room for manoeuvre of party activists would be key organizational transformations within a cartel party system. This could, however, be a trait specific to national parties' policies in the EU domain and not a cross-cutting characteristic of the entire party system.

The same argument is valid for collusion between governing and opposition parties on EU matters. Such collusion is primarily a sign of the limited saliency of EU issues rather than of the cartelization of national party systems. For example, Petithomme (2010) claims that although referendums on EU affairs offer ample opportunities for mobilization, there is a clear pattern of cooperation between the key governing and opposition parties on EU matters. Even in relation to such politically divisive EU issues as the handling of the euro crisis, government and opposition parties throughout the EU cooperated extensively in order to pass the relevant legislation, and avoided politicizing the issue (Riekmann and Wydra 2013).

As Franklin (2010) puts it, a contentious issue can be considered politically salient only if the differences at stake are adequately recognized and expressed. Moreover, the new issue has to be integrated into the existing cleavage structure, for example, the 'traditional' left-right divide, ${ }^{260}$ and provide electoral benefits (Green-Pedersen 2012). This is a challenge for 'EU topics'. Parliamentary actors do not seem to recognize the value of EU issues, not only in obtaining greater electoral support but also in bringing domestic policies closer to their own partisan preferences. The Green Paper on pensions and the Proposal for a directive on seasonal migrants could have been perceived by parliamentary actors in Sweden, the Czech Republic and Romania as fitting the 'tradi-

\footnotetext{
${ }^{260}$ In fact, an influential school of thought (Hix 2004; Hooghe et al. 2002, 2004; Marks and Steenbergen 2002, 2004; Marks and Wilson 2001) would argue that the EU issue has been subsumed into the traditional left-right divide.
} 
tional' socio-economic cleavage, but they did not integrate these EU proposals into the domestic debate on the reform of pensions and labour migration.

Despite the declining role of older socio-economic cleavages due to the decoupling of social position and voting behaviour, as well as increasing electoral volatility (Eneydi 2008), it is precisely these old socio-economic divisions that are the key guidelines for channelling political competition. Thus far, attitudes to EU integration have not been strong enough to create a sense of identity within a social group or seriously affect the behaviour of political systems (Conti 2007, p.195). Political parties are unsure about the benefits of focusing on the EU agenda, as doing so might trigger processes that could get out of their control, such as factionalism or increased activism by grassroots organisations. Although in the aftermath of the Lisbon Treaty political parties have started to address EU issues more actively ${ }^{261}$, they still seem to offer only "limited choice in terms of pro- and anti-European orientations" (van der Eijk and Franklin 2004, p.33) and do not systematically integrate EU issues into electoral competition. Large parties prefer to keep EU issues off the political agenda, while small, marginal parties are keen to politicize them. Mattila and Raunio $(2006,2012)$ offer support for this idea, arguing that congruence between party and voter opinion on EU issues is lacking across the entire political spectrum in the EU member states. Political parties strategically avoid EU issues, concentrate on the domestic agenda and make little connection between the EU and the national policy levels. This idea is supported by Pennings (2006), who comes to the conclusion that although 'Europe' is increasingly present in party manifestos, its importance in the actions of political parties is consciously downplayed.

Ultimately, 'neglect' of the content of EU proposals during national parliamentary scrutiny can be explained by the limited saliency of 'Europe' as a political cleavage. Information about the cartelization of party systems in Sweden, the Czech Republic and Romania is contradictory. Political parties can participate in the parliamentary scrutiny process but will avoid mobilizing their electorates on the EU agenda, which creates fewer incentives for a comprehensive assessment of EU proposals. It is still a matter for debate whether the saliency of EU topics is consciously downplayed by political parties or related to structural issues and the characteristics of public opinion.

\footnotetext{
${ }^{261}$ It is important to note that, for example, during the 2014 EP election campaign national political parties have not just concentrated on domestic issues but increasingly started to address the wider EU agenda. On this issue see van den Berge M. (2014). De Wilde and Zürn (2012) also develop the argument that European Union issues acquire a greater political saliency.
} 



\section{Conclusion}

This dissertation has looked at the evolution of parliamentary scrutiny systems in EU affairs in the aftermath of the Lisbon Treaty. It was considered that the adoption of the Lisbon Treaty has created a new 'opportunity structure'. This implies that a new political environment has been created in which national parliaments can participate more actively in EU affairs. The analysis addressed the development of parliamentary rules of procedure and investigated how these scrutiny provisions are used in political practice in the interactions of different types of parliamentary actors, such as parliamentary administrators, committees and political parties. Although this research cannot fully predict the behaviour of all 28 parliaments in the EU member states, the findings of the research point towards several important trends in the evolution of national parliaments as the selected cases represent different levels of 'parliamentary strength': a strong parliament (Swedish Riksdag), a medium-strong parliament (Czech Parliament) and a relatively weak legislature (Romanian Parliament). Moreover, other academic contributions (Grzelak 2014, Höing 2013, Miklin 2014, Piedrafita 2014, Neuhold and Smith 2015) point to similar findings.

\section{Factors affecting the use of the new opportunity structure}

This research identifies two factors that are crucial to the adaptation by national parliaments to the new 'opportunity structure'. The first is the integration of sectoral committees into the scrutiny process. Parliaments that are able to set up a system of regular contacts between European Affairs Committees (EACs) and sectoral committees, for example the Swedish Riksdag, have better access to technical information, are better able to integrate the opinions of different stakeholders and can participate more intensively in the Early Warning System.

The second factor that determines the adaptation of national parliaments to the post-Lisbon environment is the mode of inter-party relations. In cases where inter-party relations are focused on reaching consensus, the chances of conducting comprehensive assessments of EU proposals are greater. Moreover, parliaments with established practices of consensual decision-making seem to provide the opposition with a greater measure of leverage. It is clear that opposition parties may not always be able to influence the decision-making process, but at least in parliaments where political parties are focused on reaching consensus the opposition is able to secure regular involvement in the scrutiny process. In contrast, acute inter-party rivalry means that the scrutiny process is more likely to reflect the power struggles between the majority and the opposition. In such circumstances, the opposition will rarely be able to influence the scrutiny process. 
Moreover, inter-party rivalry creates less demand for 'expertise' on EU affairs, which can have a negative impact on the quality of the scrutiny process. In a situation of an inter-party conflict, important technical details of EU proposals run a greater risk of being disregarded or not addressed in parliamentary debates, as for example in the case of Romania and the Czech Republic where the majorities in parliamentary chambers could single-handedly determine the agenda and the course of debates.

The analysis has shown that both strong (Sweden) and weak (Czech Republic, Romania) parliaments tend to focus the scrutiny of EU affairs on the division of competences between the EU and member states and not on the content of the EU proposals. One might imagine that a comprehensive assessment of the content of EU proposals could bring parliamentary parties electoral benefits and help them bring the domestic status quo closer to their partisan preferences. In reality, however, both Eurosceptic and pro-European political parties, irrespective of whether they are in government or opposition, prioritize subsidiarity issues over the content of EU proposals during the scrutiny of EU affairs, even if addressing the latter would have helped them reach their policy objectives. Sweden, Czech Republic and Romania are not the only EU member states where parliaments focus on the division of competences during the scrutiny of EU affairs. Poland, for example, exhibits a similar trend. Grzelak (2014) argues that although the proposal for a directive on data protection in cooperation in criminal matters (COM 2012 10) raised a politically sensitive topic, the deliberation in the European Affairs Committee of the Polish Sejm has largely ignored the content of the document. The Lisbon Treaty provisions could be 'interpreted' by parliamentary actors to address the content of EU proposals in the scrutiny process and reflect on the EU and domestic policy solutions. Instead, the scrutiny process was primarily used to defend the national status quo against the spread of EU competences. The fact that the Green Paper on pensions and the Proposal for a directive on seasonal labour migrants directly refer to topics that are salient to domestic political debates did not persuade political parties to address the content of these EU's proposals. Interestingly, parallels can be drawn between the findings of the dissertation and the results presented by Maatsch (2010, p.25), who argues that the debate on EU issues in the 'new' member states was not focused on policies but addressed instead the competences of the member states and the institutional architecture of the EU.

\section{Expectations about the behaviour of parliamentary actors in the new opportunity structure}

This dissertation discussed a number of expectations about the behaviour of parliamentary actors, that is, parliamentary administrators, committees and political parties, in the post-Lisbon political environment. First, it was suggested that opposition parties, especially in countries with minority governments, will be more active in exploiting the new 'opportunity structure' in order to compensate for their weaker influence in comparison 
to the governing parties. This expectation has been largely corroborated by the information from the parliaments of Sweden, the Czech Republic and Romania.

Opposition parties do seem to have been more active in using the new 'opportunity structure' than the governing parties. Some opposition parties tried to start a dialogue with MEPs from their ideological groups (for example in Sweden), others lobbied for a change in the scrutiny rules in order to acquire greater leverage or complained to EU institutions about the government's unwillingness to involve the opposition in developing policies towards the EU. Such tactics were not widely used by the ruling parties, which can rely on close connections with the government apparatus. As is mentioned above, countries with minority governments also provide for a more comprehensive involvement of the opposition in the scrutiny process. In such cases, the lack of sufficient support forces governments to accommodate the wishes of the opposition. For example, in the Swedish Riksdag the opposition has a greater input into the country's policy on the EU than the opposition in the Czech or Romanian parliaments, the opinions of which are often disregarded by the ruling parties. Although the inter-party dialogue and consultations with the opposition in the Riksdag can be conducted informally and occasionally even outside the parliamentary arena, the Swedish parliament (in contrast to the Czech and Romanian parliaments) provides for systematic involvement of the opposition in the decision-making process ${ }^{262}$.

Second, at the outset of writing this thesis I expected that parliamentary administrators would obtain greater influence over the outcomes of the scrutiny process as a result of increased demand for EU-related information and expertise in the post-Lisbon political environment. This expectation has been falsified. Drawing on examples from the Swedish, Czech and Romanian parliaments, it can be argued that one of the main challenges for both strong and weak parliaments in conducting scrutiny of EU affairs is the lack of MPs' interest in the subject. For example, during the scrutiny of the Green Paper on pensions and the Proposal for a directive on seasonal labour migrants, MPs either disregarded notifications from parliamentary staff about important technical aspects of the proposals or made no requests for comprehensive analysis of the EU documents by parliamentary administrators.

As parliamentary staff can shape the scrutiny process primarily by providing analysis, low levels of interest in EU affairs among MPs means that parliamentary administrators have few opportunities to actively influence the scrutiny process. Moreover, political parties occasionally try to control the parliamentary administration through attempts to nominate party affiliates or by way of demands for the provision of analysis that is ideologically tainted, as examples from the Czech Republic and Romania show. This situation takes place in parliaments with acute inter-party conflicts. Under such conditions MPs can mistrust the ability of parliamentary administrators to remain 'hon-

\footnotetext{
${ }^{262}$ It should be noted, however, that the opposition in the Riksdag is ideologically very diverse. The input of distinct opposition parties may vary on a case by case basis, while the opposition in general remains systematically involved in the scrutiny process.
} 
est brokers' and try to control them in order to increase their chances in power-sharing agreements.

Third, it was considered that the role of parliamentary committees in providing expertise and coordinating the work of MPs would allow them to have some 'independent' input into the scrutiny process, which would not be fully determined by the partisan affiliation of committee members. This expectation has been falsified. Within the new 'opportunity structure' parliamentary committees have not been able to independently shape scrutiny outcomes.

It is important to note, however, that political parties have not directly shaped the behaviour of parliamentary committees: political parties do not always have a clear set of policy preferences in EU affairs that can be promoted during committee debates. Instead, political parties pre-empted the independence of the European Affairs Committees by strategically nominating second-rate politicians as committee members. These MPs find it hard to deviate from the partisan line for fear of endangering their career prospects. As a result, there are few opportunities for cross-party agreement, which could serve as a basis for the independent involvement of European Affairs Committees (EACs) in the scrutiny process. Compromises within parliamentary committees can of course be reached, as the consensual practice in the Swedish EAC demonstrates, but the EAC does not seem to play a role in brokering these deals. Conflicts between the majority and the opposition in the Czech and Romanian parliaments provide even fewer opportunities for cross-party alliances. Even in the formally strong Swedish European Affairs Committee, the majority of respondents stressed that the behaviour of the committee is determined by the party affiliation of its members. The fact that the independent involvement of the EACs, the key parliamentary bodies responsible for EU affairs, is often limited means that other sectoral committees have fewer incentives or opportunities to shape the parliamentary agenda on EU issues.

The information from the Swedish, Czech and Romanian parliaments shows that both opposition and ruling political parties have resisted any changes to the scrutiny rules that could have limited their control over the EU agenda or diminished their ability to shape scrutiny outcomes. Moreover, although it was expected that parliamentary administrators and parliamentary committees would have greater opportunities to shape the scrutiny process, their input into the assessment of EU proposals has also been preempted by political parties. Political parties have been able to marginalize other parliamentary actors, such as parliamentary administrators and committees, in the post-Lisbon environment by using a number of mechanisms:

a. Control over information exchange between committees and over the selection of documents for scrutiny by administrators;

b. Control over the nomination procedure to European Affairs Committees;

c. A power of veto over the set-up and reform of the scrutiny rules of procedure. 


\section{Typology of reactions by parliamentary actors to the new opportunity structure}

The abovementioned analysis clearly shows that various parliamentary actors have behaved differently in the new 'opportunity structure'. It should be noted, however, that due to the fact that MPs have marginalized parliamentary administrators and committees in the scrutiny process, the different types of reactions to the new 'opportunity structure' - 'voice', 'threat of issue exit' and 'neglect' - are applied primarily to political parties. Drawing on Hirschman (1970) it can be said that 'voice', or promoting the views of parliamentary actors through negotiations, has been the key reaction to the new political environment. The new 'opportunity structure' triggered a reassessment of parliamentary rules of procedure and specific practices of conducting scrutiny. The outcome of this reassessment has been determined by negotiations involving political parties and parliamentary administrators, who 'voiced' different opinions about the design of scrutiny rules and practices. The inter-party negotiations in the Swedish Riksdag over the report of the EUMOT working group as well as the debates between governing and opposition parties in the Romanian Parliament over the content of the law on executivelegislative cooperation on EU affairs provide examples of 'voice'. Despite the fact that in both cases the initial suggestions were prepared by parliamentary administrators, they had little input into the subsequent debates between various groups of MPs. 'Threat of issue exit', or attempts by the opposition to directly address EU-level institutions and stakeholders in order to put pressure on the government, has been used only rarely. Contacts with MEPs, EU institutions and stakeholders provide opposition parties with channels to 'exit' (transfer) policy issues from the domestic to the EU arena, obtain support and exert pressure on domestic governments. Although there are instances of opposition parties employing such strategies, 'threat of issue exit' has not enjoyed widespread use. One of the few examples is the direct complaint by the Czech Senate (controlled by the opposition) to the European Commission about the actions of the Czech Government, which allegedly failed to involve the upper chamber in the discussion of several documents related to the 'European Semester'. It is important to note that the contacts established by national parliamentary actors with the EU institutions, stakeholders and MEPs are not widely used for policy coordination or for directly influencing the EU policymaking process. Although in the aftermath of the Lisbon Treaty national scrutiny systems show no signs of convergence, the assessment of scrutiny practice in the parliaments of Sweden, the Czech Republic and Romania has focused on subsidiarity issues and not on the content of EU proposals, even where it could have brought electoral benefits and helped move the status quo in some domestic policy areas closer to partisan preferences. As the analysis of the debates around the Green Paper on pensions and the Proposal for a directive on seasonal migrants shows, actors in both strong and weak parliaments tend to neglect the content of EU proposals. 


\section{Expectations about the causes of neglect of the content of EU proposals by political parties}

In this dissertation, I address two expectations which could explain the reasons why political parties tend to 'neglect' the content of EU proposals during parliamentary scrutiny. The first expectation relates to the alleged transformation of national party systems into a 'party cartel' (Katz and Mair 1995, 2009), which discourages the introduction of new issues into the political debate and promotes collusion between government and opposition parties. As a result it is considered that party systems with strong cartelization traits are likely to 'neglect' the content of EU proposals during parliamentary scrutiny because increased attention on EU issues may endanger the position of incumbent parties and help 'break the cartel'. The second expectation refers to the role of the 'EU political cleavage'. According to it, members of parliament neglect the content of EU proposals because they do not perceive EU issues to be an important element in structuring political competition. As a result, EU issues are not used to mobilize voters and play a limited role in inter-party debates. Hence, MPs do not have many incentives to address the content of EU proposals as in their opinion this brings very few political benefits.

The first expectation has not materialized. The evidence about the level of cartelization in the Swedish, Czech and Romanian party systems is mixed. In the Swedish case, the practice of 'contract parliamentarianism', that is, formal commitments by parties to collaborate on distinct topics, speaks in favour of cartelization, but the reliance of Swedish political parties on public funding seems to be more of a national tradition than a sign of cartelization ${ }^{263}$. The Czech party system has also been considered cartelized, but the fact that in the 2010 general elections the two main parties (the Social Democrats and the Civic Democrats) acquired less than half of all votes, allowing two new parties to enter parliament, raises doubts about the existence of a Czech "party cartel'. On the other hand, electoral laws in Romania are extremely restrictive, making it almost impossible for new parties to enter parliament. Nonetheless, the high levels of inter-party conflict are somewhat incompatible with the 'party cartel' ideal type. As a result, the 'party cartel' thesis does not find unequivocal support and cannot be considered a sufficient explanation of political parties' 'neglect' of the content of EU proposals.

By contrast, the absence of an 'EU political cleavage' offers a better explanation of the political parties' 'neglect' of the content of EU proposals. For example, expert assessments and interview data suggest that Swedish political parties have tried to isolate EU issues in the inter-party discussion for fear of undermining internal party cohesion.

\footnotetext{
${ }^{263}$ Increased reliance of political parties on public funding (as opposed to members' contributions) is considered as one of the key elements of the 'party cartel' thesis (Katz and Mair 1995; Katz and Mair 2009), although in the case of Sweden public funds have always played an important role in party financing and thus cannot be considered as a sign of transformation of the Swedish party system towards a cartel model,
} 
Swedish parties are generally in favour of EU integration but, arguably, representatives of both 'left' and 'right' political parties agree on keeping the EU's influence on the 'Swedish model' to a minimum. The Czech debate on the EU has so far been dominated by Eurosceptic politicians, but this has not translated into a higher saliency of EU issues - the 2010 general elections were devoid of EU-related topics. Both pro-European and Eurosceptic political parties in the Czech Republic downplay EU issues because they fear that doing otherwise would demonstrate the discrepancy between the attitudes to the European Union of the party leadership and those of party supporters. Drawing on Hörner (2013) it can be said that even Eurosceptic parties will be less publicly active in EU affairs out of fear of endangering internal party cohesion. In Romania, EU issues are not important in structuring inter-party competition and achieve prominence in the public debate chiefly in conjunction with the issue of cohesion funds. Indirectly, the limited role of the EU cleavage in structuring political competition in Sweden, the Czech Republic and Romania can be supported by the fact that in none of these countries do national parties have a powerful cadre of EU experts. In general, EU issues are not very important to the internal administration of the Swedish, Czech and Romanian political parties.

The information from Sweden, the Czech Republic and Romania, however, does not show whether this low saliency of EU issues is a reflection of structural problems with politicizing the EU agenda or the result of a conscious strategy by political parties to diminish the importance of EU issues. Nonetheless, the argument about the limited saliency of EU issues is consistent with the findings of Ladrech (2007), Poguntke (2007) and Petithomme (2010) on the role of EU affairs in structuring party competition. Ultimately, for the majority of political parties a pro-European or Eurosceptic stance would be more an instrument of inter-party struggle than a reflection of ideological convictions towards the EU.

In the long term, 'neglect' of the content of EU proposals may pose a challenge to parliamentary scrutiny. Disregard of the content of EU proposals means that political parties fail to grasp electoral opportunities and to bring domestic policies closer to their own preferences. This could also result in a situation in which non-mainstream, marginal Eurosceptic parliamentary parties are in charge of the debate on the EU. This lack of parliamentary interest in EU affairs may have important consequences for the evolution of parliamentary institutions in the European Union. By neglecting the EU agenda, parliaments de facto relegate the discussion of EU issues to new types of political actors, such as social movements and NGOs.

This changes the patterns of interest representation and policymaking as traditional political institutions run the risk of being replaced by new types of political actors or radical parties when discussing EU affairs. Moreover, the fact that deliberation about the EU could run through NGOs or civil society actors and not parliaments could create a situation in which the discussion is captured by sectoral interests with little room for feedback or concern for the public good (Auel 2012, p.14). In the long term, parliaments 
may lose their function of transforming voters' preferences into policies as well as the ability to establish national consensus on EU affairs. For example, Miklin (2014, p.1199) argues that although "the euro crisis has clearly increased the saliency of European issues, overall the incentive structure of mainstream parties in many member states still works against publicly visible discussions among them”. Research by Riekmann and Wydra (2013) has also shown that on many occasions the legislation on measures to tackle the euro crisis was supported by both government and opposition parties. According to the authors, this could imply an unwillingness by the opposition to exert control over the government but could also lead to deficits in representation through the collusion of political elites and privileging the interests of some member states over others. By avoiding a content-orientated debate on EU affairs, national parliaments ultimately damage their long-term credibility.

It can thus be concluded that the new 'opportunity structure' has offered national parliaments the instruments to become more active and influential in EU affairs, through the Lisbon Treaty provisions and the subsequent reforms of domestic scrutiny rules, but has not been able to make national parliaments assign greater priority to EU affairs.

\section{New definition of parliamentary strength}

It is important to note that in the new 'opportunity structure' neither the parliaments that are generally considered strong (the Swedish Riksdag), nor the weaker parliamentary chambers of the Czech Republic and Romania have come to rely less on the government for the analysis of EU proposals. No parliament seems to be able to do this on its own. This constitutes a strong challenge to national parliaments' independence in EU affairs, as their ability to comprehensively assess EU information could potentially be compromised.

This observation requires a reassessment of the definition of parliamentary strength that is used in this thesis. According to the definition, a parliament can be considered influential if it can independently obtain and analyse information and if it can force the government to adopt its point of view in cases where opinions of the executive and the legislative diverge. In practice, even the parliaments that are considered strong cannot fulfil the 'information criterion' and conduct scrutiny without recourse to the government's information and analytical services. As a result, it could be argued that it is not the ability to assess EU documents independently that is important but the fact that a parliament receives well-prepared governmental memoranda on EU proposals on time.

Moreover, an outright conflict between the executive and the legislature is rare in parliamentary systems, as it is the parliamentary majority that forms the government. Although such executive-legislative conflicts could take place in bicameral systems, where the opposition can obtain control of one of the chambers, respondents from the Swedish, Czech and Romanian parliaments did not provide any clear examples of a 
major executive-legislative conflict on EU affairs. Respondents, however, mentioned that majority-opposition relations structure the scrutiny process. In fact, what seems to make a parliament stronger is the ability to involve the opposition in the scrutiny process in a regular way.

I therefore propose a new definition of 'parliamentary strength' in relation to EU affairs. According to the new definition, a parliament can be considered strong if it meets two criteria:

1. Timely access to well-prepared government memoranda on EU proposals;

2. Established mechanisms for reaching consensus between government and opposition parties.

This definition provides a better understanding of parliamentary involvement in EU affairs. .Auel, Rozenberg and Tacea (2015b) also point out that access to information is one of the key parameters of 'parliamentary strength' in EU affairs. My argument about inter-party consensus-building mechanisms is new and has not been reflected in rankings of national parliaments, either in terms of their institutional strength or activity in the domain of EU affairs. Interestingly, even if the new definition of 'parliamentary strength' is adopted, it is still the Swedish Riksdag that ranks top with the Czech Parliament and the Romanian Parliament having less and the least influence, respectively. Hence, it can be seen that the new 'opportunity structure' does not have to make national parliaments 'independent' in order to increase their leverage on EU affairs. Arguably, what matters much more is the ability to establish a stable working relationship between parliament and government in the post-Lisbon political environment. As a result, even if parliamentary majorities change, the infrastructure for involving all parliamentary parties and providing them with the necessary technical information will be available. U1timately, it is not the ability of parliament to shape the government's policy in a particular EU-related case that matters, but the availability of mechanisms that can guarantee the stable and long-term involvement of parliament in formulating national policy on the EU.

The analysis shows that although the parliaments of Sweden, the Czech Republic and Romania have been involved in changing their scrutiny procedures, within the new 'opportunity structure' the key characteristics of the scrutiny systems have remained stable. The evolution of parliamentary scrutiny procedures has been highly pathdependent. It seems that the behaviour of national parliaments in the new 'opportunity structure' has remained much more dependent on domestic political factors than the EU. For example, Damgaard and Jensen (2005, p.394) in their analysis of the Danish Parliament, claim that "the impact of the EU on national executive-legislative relations has less to do with the EU than with the national organization of executive-legislative relations". This seems to hold true for the parliaments of Sweden, the Czech Republic and Romania. 
The post-Lisbon environment has not brought comprehensive changes to the 'strength' of the Swedish, Czech and Romanian parliaments: the former has remained strong, the other two rather weak. The claim that the impact of the Lisbon Treaty on national parliamentary scrutiny has been path-dependent can also be supported by examples from Spain and Germany. Piedrafita (2014) mentions that although Spain introduced a more systematic procedure for parliamentary scrutiny, it has rarely been used to control the executive and standing committees are involved only to a limited extent. In other words the Spanish parliament has not been able to greatly increase its leverage in the domain of EU affairs. In fact, the development of the Romanian parliament in the aftermath of the Lisbon Treaty bears strong resemblance to that of Spain. Both parliaments have introduced new institutional provisions but it remains to be seen how they are going to be used in practice. Broadly speaking 'weak' parliaments have not been able to escape this category and become 'strong' in the domain of EU affairs.

'Strong' parliaments have remained strong. The German parliament has only become more influential in EU affairs, widening the gap between 'strong' and 'weak' parliaments within the EU (Höing 2013). In fact, Sweden is now considered one of the best examples of effective scrutiny system, surpassing Denmark which has long been seen as a 'textbook model' in EU affairs (Neuhold and Smith 2015).

Nonetheless, the claim that the transformation of national scrutiny systems has remained path-dependent does not mean that the 'post-Lisbon' environment has not brought any important changes. On the contrary, it remains to be seen how some of the procedural changes prompted by the adoption of the Lisbon Treaty will affect the status of national parliaments. For example, although the Romanian law on executivelegislative cooperation on EU affairs, adopted in December 2013, has a number of weak points, it could be the first step towards improving the status of the Romanian Parliament in the field of EU policy.

\section{An agenda for further research}

The findings of this dissertation as well as the limitations of the research design help identify several aspects in the analysis of national parliaments and European integration which merit further investigation. For example, I have found that political parties are the key actors that shape the adaptation of national parliaments to the post-Lisbon political environment. Moreover, political parties have limited the leverage of parliamentary administrators on the outcomes of scrutiny by generating few demands for in-depth analysis of EU proposals. It remains unclear, however, what role party administrations and experts play in shaping the behaviour of MPs during the scrutiny process. For example, Poguntke et al. (2007) argue that party experts on EU affairs have limited political influence and never acquire an influential public profile, but it remains unclear whether this observation still holds in the post-Lisbon political environment. It is also important to understand whether parliamentary EU experts and party EU experts inter- 
act, as this could have consequences for the ability of MPs to make informed decisions as well as the role of parliamentary staff in conducting scrutiny of EU affairs.

This dissertation has also argued that in the post-Lisbon political environment opposition parties have started to establish contacts with EU institutions and stakeholders to take the opportunity to put pressure on the government. Some of these initiatives, for example, contacts between Swedish Social Democrats in the Riksdag and the European Parliament, are very recent. Hence it is important to continue analysing such activities in order to understand the implications of such contacts for policymaking and the scrutiny of EU affairs. Ultimately, analysis of inter-parliamentary cooperation within the format of MP-MEP dialogue, meetings of national parliamentary staff or contacts between the European Parliament and national parliaments would provide insights into the evolution of a 'multilevel parliamentary field' (Crum and Fossum 2009) as well as policymaking at both the national and the EU levels.

The findings of this research have been based on the analysis of parliamentary scrutiny of EU proposals in the domains of pensions and labour migration policies. An important policy field was not included in the case selection: the role of national parliaments in debating and implementing measures aimed at tackling the economic crisis. Some research has already been done on the attitudes of political parties to the bail-out programmes (Maatsch 2014; Closa and Maatsch 2014) as well as on the conduct of inter-parliamentary dialogue on the 'Fiscal Compact' (Fasone 2014). Höing (2013) notes that there is growing differentiation between national parliaments on how they address the economic crisis and whether they are able to control their government's policy measures. This topic will definitely need to be explored in more detail as it touches on the key aspects of parliamentary power: so far measures against the economic crisis "operate beyond effective parliamentary scrutiny" (Crum 2013, p.622). One of the crucial principles of parliamentary democracy is "no taxation without representation'. Hence, greater budget coordination among EU member states as well as the involvement of the European Commission in this process raise fundamental questions about the role of national parliaments.

In order to assess the involvement of different types of parliamentary actors in the scrutiny process, this dissertation has focused on parliamentary committees, paying less attention to the role of the plenary in structuring debates on EU issues. Nonetheless, according to the 'communicative turn' in the studies of national parliaments and EU integration (Auel and Raunio 2014), the role of the plenary is important for articulating and representing attitudes to the European Union as well as informing the electorate about EU issues. Taking into consideration the urgent challenge of 'bringing the EU closer to citizens', research on the role of EU issues in plenary debates and constituency service $^{264}$ as well as the use of new social media in communicating and debating about the EU agenda will be highly salient.

\footnotetext{
${ }^{264}$ See Chapter 1 for the definition of 'constituency service'.
} 
Despite the fact that a lot of work has already been done on the issue of the congruency of attitudes towards the EU between the party leadership and voters (Rohschneider and Whitefield 2012; Matilla and Raunio 2006, 2012; Walczak and de Brug 2013; Vasilopoulou and Gattermann 2013; Cassado-Asensio and Lefkofridi 2011; McEvoy 2012; Costea, Thomassen and Rosela 2012; Arnold, Sapir and de Vries 2012), a lot of these studies have concentrated on elections to the European Parliament, rather than national parliaments and domestic elections. In order to address this research agenda and develop the 'communicative turn' in the studies of national parliaments and EU integration, both qualitative and quantitative approaches will be needed, the former providing insights into the discursive practices involved in such communication, the latter helping to determine the factors responsible for cross-country variation.

This dissertation has focused on the evolution of parliaments in Central and Eastern Europe, as there is little information on the way national parliaments in this region adapted to EU integration in the aftermath of the fifth round of enlargement. This research cannot provide a comprehensive assessment of the evolution of all 28 parliaments in the EU member states under the new 'opportunity structure' but findings of Höing (2013), Piedrafita (2014), Grzelak (2014) point to similar trends in other national parliaments. This can be complemented by more in-depth analysis of other national parliaments. For example, the parliaments of South European member states have traditionally been considered rather weak. It is important to understand whether all parliaments of this regional group adapt to the Lisbon Treaty in a similar way, especially given the fact that many of them have had to approve harsh austerity measures.

The fact that Croatia joined the EU in 2013 raises questions about the role of national parliaments in accession negotiations, especially in relation to the candidate states of South-Eastern Europe. The process of Eastern enlargement has to some extent supported the dominance of the executive branch, as parliaments seem in most cases to have had little choice but to rubber-stamp the transposition of the acquis (Haughton 2007, Sedelmeier 2011), which may weaken parliamentary influence in the long term. This raises concerns about whether the same pattern will be repeated in case of the Balkan candidate states. There is limited information on how the parliaments of the Balkan countries have dealt with EU integration, whether they have had an input into accession negotiations and to what extent EU topics constitute an important part of the internal parliamentary debate (Balfour and Stratulat 2011). As with the research on parliaments in Western as well as Central and Eastern Europe, it is important to go beyond formal institutional competences to look at the practical implementation of parliamentary powers in the Balkan region.

Like the overwhelming majority of studies on national parliaments and EU integration, this dissertation has addressed the political processes in EU member states. The impact of EU integration, however, cannot be confined to the borders of the EU. The European Union is an important actor in world politics that aims to promote its own 
norms and practices in the international arena ${ }^{265}$. Bearing this in mind, it is important to investigate, for example, how the parliaments of the EU partner states within the European Neighbourhood Policy (ENP) address EU issues and assist in formulating their governments' negotiation strategies. Thus far, this topic does not seem to have attracted a lot of attention in the academic debate, Kostanyan and Vandecasteele (2013) being one of the few exceptions. A focus on the role of national parliamentary structures in the ENP could lead to a better understanding of the domestic factors that influence the relationship between the EU and its partner states.

\footnotetext{
${ }^{265}$ For a review of the state-of-the-art literature on the international impact of the EU integration process see Schimmelfennig U. (2012). Europeanization beyond Europe, in Living reviews in European governance, 7:1
} 



\section{Bibliography}

\section{Primary sources $^{266}$}

COSAC (2005) Third bi-annual report: Developments in the European Union procedures and practices relevant to parliamentary scrutiny. May 2005

COSAC (2006) Sixth bi-annual report: Developments in the European Union procedures and practices relevant to parliamentary scrutiny. November 2006

COSAC (2007a) Seventh bi-annual report: Developments in the European Union procedures and practices relevant to parliamentary scrutiny. May 2007

COSAC (2007b) Eighth bi-annual report: Developments in the European Union procedures and practices relevant to parliamentary scrutiny. October 2007

COSAC (2008a) Ninth bi-annual report: Developments in the European Union procedures and practices relevant to parliamentary scrutiny. May 2008.

COSAC (2008) Tenth bi-annual report: Developments in the European Union procedures and policies relevant to parliamentary scrutiny. November 2008

COSAC (2009) Eleventh bi-annual report: Developments in the European Union procedures and policies relevant to parliamentary scrutiny. May 2009

COSAC (2010) Thirteenth bi-annual report: Developments in the European Union procedures and practices relevant to parliamentary scrutiny. May 2010

EPC-SPC (2010). Joint report on pensions. Brussels. 31/05/2010

European Convention (2002) Final report of Working Group IV on the role of national parliaments. CONV 353/02. Brussels, 22 October 2002

European Convention (2002). Working group IV. Working document 18. "National parliaments and the EU: the Swedish experience". Brussels

European Council (2001). Laeken Council conclusions, 14-15 December 2001

EC Commission (1972) Report of the Working Party examining the problem of the enlargement of the powers of the European Parliament: Report Vedel

European Commission (2002). For the European Union. Peace, Freedom, Solidarity. Communication of the Commission on the Institutional architecture. COM (2002) 0728. Brussels, 11.12.2002

European Commission (2006) Communication from the European Commission to the European Council. A citizen's agenda. Delivering results for Europe. COM (2006) 0211 final. Brussels, 10.05.2006

European Commission (2008). Annual report 2007 on relations between the European Commission and national parliaments. COM (2008) 237 final. Brussels, 06.05.2008

European Commission (2009). Annual report 2008 on relations between the European Commission and national parliaments. COM (2009) 343 final. Brussels, 07.07.2009

European Commission (2010). Annual report 2009 on relations between the European Commission and national parliaments. COM (2010) 0291. Brussels, 02.06.2010

European Commission (2011). Annual report 2010 on relations between the European Commission and national parliaments. COM (2011) 345 final. Brussels, 10.06.2011

European Commission (2012). Annual report 2011 on relations between the European Commission and national parliaments. COM (2012) 375 final. Brussels, 10.07.2012

European Commission (2013). Annual report 2012 on relations between the European Commission and national parliaments. COM (2013) 565 final. Brussels, 30.07.2013

\footnotetext{
${ }^{266}$ See other references to primary sources in the main body of the text
} 
European Commission (2014). Annual report 2013 on relations between the European Commission and national parliaments. COM (2014) 507 final. Brussels, 05.08.2014

European Parliament (1988) Report drawn up on behalf of the Committee on Institutional Affairs on the democratic deficit in the European Community (Toussaint report). PE Doc. No. 2-0276/87

European Parliament (2014). Report on "inter-parliamentary relations between the European Parliament and national parliaments under the Lisbon Treaty” 2009-2014. Annual report 2013/2014. Brussels

\section{Literature references}

Ágh A. (1994). The emergence of East Central European parliaments: the first steps. Budapest: Hungarian centre of democracy studies foundation

Agh A. (2004). Post-accession in Central and Eastern Europe. The emergence of the EU 25. Budapest: Hungarian Center for Democracy Studies Foundation

Ágh A. (2006). The role of Central European Parliaments in EU integration, in Holzhacker R, Albaek E. (eds). Democratic governance and European Integration: Linking societal and state processes of democracy. Cheltenham: Edward Elgar Publishing

Agostini, M. (2001). The role of national parliaments in the future EU, in International Spectator, 36:4, 29-41

Alexe I. (2010). Romania, in Migration, employment and labour market integration policies in the European Union. Part II: Labour market integration policies in the European Union (2000-2009). IOM LINET. Brussels

Andersen S., Eliassen K (1996). The European Union: How democratic is it? L: Sage Publications

Andersen K., Immergut E. (2007). Sweden: after social democratic hegemony, in Immergut E., Anderson K., Schulze I. (eds) The handbook of West European pension politics. Oxford: Oxford University Press

Anderson K., Meyer T. (2003). Social democracy, unions, and pension policy in Germany and Sweden, in Journal of Public Policy, 23:1, 23-54

Armeanu O. (2010). The politics of pension reform in Central and Eastern Europe. N.Y: Palgrave Macmillan Arter D. (1999). Scandinavian politics today. Manchester: Manchester University Press

Arter D. (2006a). Introduction: Comparing the legislative performance of the legislatures, in Journal of Legislative Studies, 12:3-4, 245-257

Arter D. (2006b). Conclusion. Questioning the "Mezey question": An interrogatory framework for comparative studies of legislature, in Journal of Legislative Studies, 12:3-4, 462-482

Arts B., Verschuren P. (1999). Assessing political influence in complex decision-making: An instrument based on triangulation, in International Political Science Review, 20:4, 411-424

Auel K. (2005) Introduction: The Europeanisation of parliamentary scrutiny, in Journal of Legislative Studies, $11: 3-4,303-318$

Auel K. (2006). Europeanisation in the German Bundestag Institutional reforms and informal adaptation, in German Politics, 15:3, 249-268

Auel K. (2009). "Servants of the people” or "Masters of the government”? Explaining parliamentary behavior in EU affairs. Paper for presentation at the $11^{\text {th }}$ Bi-annual conference of the European Union Studies Association, Los Angeles, April 23-25, 2009

Auel K. (2011). Europäisierung der parlamentarischen Demokratie theoretische Perspektiven und methodologische Herausforderungen, in Abels G., Eppler A. (Hrsg.) Auf dem Weg zum Mehrebenparlamentarismus? Funktionen von Parlamenten im politischen System der EU. Baden-Baden: Nomos Verlag

Auel K., Benz A. (eds). (2005). The Europeanization of parliamentary democracy. London: Routledge

Auel K., Höing O. (2014). Parliaments in the euro crisis: can the losers of integration still fight back?, in the Journal of Common Market Studies, 52:6, 1184-1193

Auel K., Raunio T. (2011) Debating the state of the Union? A comparative analysis of national parliamentary debates on EU affairs. Paper prepared for the $6^{\text {th }}$ ECPR General conference. Reykjavik, 25-27 August

Auel K., Raunio T. (2014). Introduction: Connecting the electorate? Parliamentary communication in EU affairs, in Journal of Legislative Studies, 20:1, 1-12 
Auel K., Raunio R. (2012) Introduction: National parliaments, electorates and EU affairs, in Auel K., Raunio T. (eds.) National parliaments, electorates and EU affairs. Institute for Advanced Studies. Vienna. Political Science Series 129

Auel K., Rozenberg O., Tacea A. (2015a). To scrutinize or not to scrutinize? Explaining variation in EUrelated activities in national parliaments, in West European Politics Special issue

Auel K., Rozenberg O., Tacea A. (2015b). Fighting back? And if yes, how? Measuring parliamentary strength and activity in EU affairs in in Hefftler C., Neuhold C., Rozenberg O., Smith J., Wessels W. (eds.) Palgrave handbook of national parliaments and the European Union. L.: Palgrave

Aylott N. (2010). Europe and the Swedish election of September $19^{\text {th }} 2010$. EPERN Election Briefing №59.

Aylott N. (2002). Let's discuss this later: party responses to Euro-division in Scandinavia, in Party Politics, $8: 4,441-461$

Bach F. (2008). Parlamentarische Mitwirkung in der Angelegenheiten der Europäischen Union. Tübingen: Mohr Siebeck

Barkgaard M., Blom-Hansen J., Serritzlew S. (2014). When politics matters: the impact of politicians' and bureucrats' preferences on salient and non-salient policy areas, in Governance (Early View)

Bale T., Bergman T. (2006) Captives no longer, but servants still? Contract parliamentarism and the new minority governance in Sweden and New Zealand, in Government and Opposition, 41:3, 422-449

Barberis P. (2011). The Weberian legacy, in A. Massey (ed). International Handbook on Civil Service Systems. Cheltenham: Edward Elgar

Barrett G. (2008). National parliaments and the European Union. The Constitutional challenge for the Oireachtas and Other member State Legislatures. Dublin: Clarus Press

Bartolini S. (2005). Restructuring Europe. Oxford: Oxford University Press

Bausili A.V. (2002). Rethinking the methods of dividing and exercising powers in the EU: reforming the subsidiarity and national parliaments. Jean Monnet Working Paper 09/2002

Basilien-Gainche M.L. (2009) 'Parlements scandinaves et affaires européennes: Quand le côntrole de l'action gouvernementale deviant modèle’, in Revue du Marché commun et de l’Union européenne, №531, 527532

Batory A. (2009). The dog that did not bark? Assessing the impact of the EU on party politics in Hungary, in Journal of Communist Studies and Transition politics, 25:4, 427-446

Beach D., Pedersen R.B. (2013). Process-tracing methods. Foundations and guidelines. The University of Michigan press: Ann Arbor

Becker S. (2009). The role of national parliaments in the Open Method of Coordination. SWP Working Paper

Beichelt T. (2012) Recovering space lost? The German Bundestag's new potential in European politics, in German Politics, 21:2, 143-160

Bellamy R. (2010). Democracy without democracy? Can the EU's democratic “outputs” be separated from the democratic "inputs" provided by competitive parties and majority rule, in Journal of European Public Policy, 17:1, 2-19

Bellamy R., Kröger S. (2014). Domesticating the democratic deficit? The role of national parliaments and parties in the EU's system of governance, in Parliamentary affairs, 67:2, 437-457

Bellamy R., Kröger S. (2013). Representation deficit and surpluses in EU policy-making, in Journal of European integration, 35:5, 477-497

Bendor J., Moe T. (1989). An adaptive model of bureaucratic politics, in The American Political Science Review, 79:3, 755-774

Bengston C. (2006). National parliaments and European legislation. How scrutiny procedures have adapted and why? University of Glasgow. PhD dissertation. Unpublished manuscript

Bergman T., Bolin N. (2011). Swedish democracy. Crumbling political parties, a feeble Riksdag, and technocratic power holders?, in Bergman T., Strøm K. (eds). The Madisonian turn. Political parties and parliamentary democracy in Nordic Europe. The University of Michigan Press: Ann Arbor

Berghman J., Okma K. (2002). The method of open coordination: open procedures or closed circuits? Social policy making between science and politics, in European Journal of Social Security, 4:4, 331-341

Bergman T. (1997). National parliaments and EU affairs committees: notes on empirical variation and competing explanations, in Journal of European Public Policy, 4:3, 373-387 
Bergman T., Damgaard E. (eds) (2000) Delegation and accountability in European integration: The Nordic parliamentary democracies and the European Union. L.: Frank Cass

Berry J.M.(2002). Validity and reliability issues in elite interviewing, in PS: Political science and politics, $35: 4,679-682$

Bertozzi S. (ed). Opening Europe's doors to unskilled and low-skilled workers: A practical handbook. BEPA: Brussels. 2010

Besselink L.M., van Mourik B. (2009). The roles of the national parliament and the European Parliament in EU decision-making: The approval of the Lisbon Treaty in the Netherlands, in European Public Law, $15: 3,307-318$

Birnir J. (2010). Where are the disgruntled voters?: Voter-party relations under cartelizing conditions, in Party politics, 16:1, 29-49

Blatter J., Haverland M. (2012). Designing case studies. Explanatory approaches in small-N research. N.Y.: Palgrave

Blondel J. (1970). Comparative legislative behavior, in Government and Opposition, 5:1, 67-85

Blondel J. (1974). Comparative legislatures. Englewood Cliffs: Prentice-Hall

Blyth M., Katz R. (2005). From catch-all parties to cartelization: The political economy of a cartel party, in West European politics, 28:1, 33-60

Böcker J. (2012.) Demokratiedefizit der Sicherheits und Verteidigungspolitik der EU? Analyse der deutschen, britischen und Europäischen Parlaments, Baden-Baden: NomosVerlag

Bogner A., Menz W. (2009). The theory-generating expert interview: epistemological interest, forms of knowledge, interaction, in Bogner A., Littig B., Menz W. (eds.) Interviewing experts. N.Y.: Palgrave Macmillan

Bolleyer N. (2009). Inside the cartel party: Party organization in government and opposition, in Political Studies, 57:3, 559-579

Bono G. (2005). National Parliaments and EU External Military Operations: Is there any parliamentary control?, in European Security, 14:2, 203-229

Börzel T. A., Sprungk C. (2009). The goodness of fit and the democratic deficit in Europe, in Comparative European Politics, 7:3, 364-373

Boronska-Hryniewiecka K. (2013). Subnational parliaments in EU policy control: explaining the variations across Europe. EUI Working Papers. RSCAS 2013/38

Boswell C., Geddes A. (2011). Migration and mobility in the European Union. N.Y.: Palgrave Macmillan.

Bovenberg L., van Ewijk (2011). The future of multi-pillar pension systems. Netspar Discussion paper. DP 09/2011-079.

Brouard S., Costa O., König T. (2012). The Europeanization of domestic legislatures. The empirical implications of the Delors' myth in nine countries. N.Y.: Springer

Bucken-Knapp G. (2009). Defending the Swedish model. Social democrats, trade unions, and labour migration policy reform. Lanham, Boulder: Lexington Books

Buhr R. (2009). The purported demise of the permissive consensus and the evidence of its survival. Paper presented at the ISA $50^{\text {th }}$ annual convention. New York, 15-18 February

Buzek J. (2011). State of the Union: three cheers for the Lisbon Treaty and two warnings for political parties, in Journal of Common Market Studies, 49:s1, 7-18

Carrera S., Atger A.F., Guild E., Kostakopoulou D. (2011). Labour immigration policy in the EU: A renewed agenda for Europe 2020. CEPS Policy Brief. № 240.

Cartabia M. (2007). Prospects for national parliaments in EU affairs What should and could be saved in the case of non-ratification?, in Amato G., Bribosia H., de Witte B. (eds) Genesis and destiny of the European Constitution. Bruxelles: Bruylant

CEPS (2010). Impact of the seasonal employment of third-country nationals on local and regional authorities. Bruxelles

Cerami A. (2006). Social policy in Central and Eastern Europe. The emergence of new European welfare regime. Berlin: LIT Verlag

Cerna L. (2009). Changes in Swedish Labour immigration policy: a slight revolution? SULCIS Working Papers 
Checkel J. T. (2005). 'It's the process, stupid! Process tracing in the study of European and International Politics', ARENA Working Papers, № 26

Checkel J.T. (2006). Tracing causal mechanisms, in International Studies Review, 8:2, 362-370

Chiva C. (2007). The institutionalization of post-communist parliaments: Hungary and Romania in comparative perspective, in Parliamentary affairs, 60:2, 187-211

Chloń-Domińczak A., Mora M. (2006). The NDC reform in the Czech Republic, in Holzman R., Palmer E. (eds) Pension reform. Issues and prospects for Non-financial defined contribution (NDC) schemes. Washington: IBRD

Christiansen F.J., Damgaard E. (2008). Parliamentary opposition under minority parliamentarism: Scandinavia, in Journal of Legislative Studies, 14:1-2, 46-76

Christiansen T., Högenauer A.-L. and Neuhold C. (2014) National parliaments in the post-Lisbon European Union: Bureaucratization rather than Democratization, in Comparative European Politics, 12:2, 121140

Citi M., Rhodes M. (2007). New modes of governance in the EU: common objectives versus national preferences, in European Governance Papers. № N-07-01

Closa C., Maatsch A. (2014). In a spirit of solidarity? Justifying the European Financial Stability Facility (EFSF) in national parliamentary debates, in Journal of Common Market Studies, 52:4, 826-842

Collett E. (2009). Beyond Stockholm: overcoming the inconsistencies of immigration policy. EPC Working Paper №32. EPC: Brussels

Collett E. (2011). Future prospects for a common EU immigration policy, in Karlsson J., Pelling L. (eds) Moving beyond demographics. Stockholm: Global Utmaning

Conti N. (2007). Domestic parties and European integration: the problem of party attitudes to the EU, and the Europeanisation of parties, in European Political Science, 6:2, 192-207

Coombes D., Hrbek R. et al. (eds) (1979). European integration, regional devolution and national parliaments. L.: Policy Studies Institute

Cooper I.(2006). The Watchdogs of Subsidiarity: National Parliaments and the Logic of Arguing in the EU, in the Journal of Common Market Studies, 44:2, 281-304

Cooper I. (2012). A 'virtual third chamber' for the European Union? The national parliaments after the Treaty of Lisbon, in West European Politics, 35:3, 441-465

Cooper I. (2013a). Bicameral or Tricameral? National parliaments and representative democracy in the European Union, in Journal of European integration, 35:5, 531-546

Cooper I. (2013b). A yellow card for the striker: How national parliaments defeated EU strikes regulation. Paper presented at the meeting of the European Union Studies Association, Baltimore, May 9-11

Cooper I. (2013c). Deliberation in the multilevel parliamentary field: the seasonal workers directive as a test case, in Crum B., Fossum J. (eds) Practices of inter-parliamentary coordination in international politics. The European Union and beyond. Colchester: ECPR Press

Costa O., Kerrouche E. , Magnette P. (2004). Le temps de parlementarisme désenchanté, in O.Costa, Kerrouche E., Magnette P. (eds). Vers un renouveau du parlementarisme en Europe. Bruxelles: Université de Bruxelles

Costa O., Latek M. (2001). Paradoxes et limites de la cooperation interparlementaire dans l'Union européenne, in Journal of European Integration, 23:2, 139-164

Costa O., Rozenberg O. (2008) Parlementarismes, in Belot Céline, Magnette Paul, Saurugger Sabine (eds) Science politique de l'Union européenne. Paris: Economica

Cox G., McCubbins M. (1993). Legislative leviathan: party government in the House. Berkeley and Los Angeles: University of California Press

Crum B. (2013). Saving the euro at the cost of democracy?, in the Journal of Common Market Studies, 51:4, 614-630

Crum B., Fossum J. E. (2009). The multi-level parliamentary field: a framework for theorizing representative democracy in the EU, in European Political Science Review, 1:2, 249-271

Crum B., Miklin E. (2011). Inter-parliamentary contacts of the members of the European Parliament. Report of a survey, in RECON Online Working Paper 11/08.

Dahl R., Steinbrickner B. (2003) Modern political analysis. $6^{\text {th }}$ ed. Englewood Cliffs: Prentice Hall 
Damgaard E., Jensen H. (2005). Europeanisation of executive-legislative relations: Nordic perspectives, in Journal of Legislative Studies, 11:3-4, 394-411

Damgaard E., A.S.Nørgaard (2000). The European Union and the Danish Parliamentary Democracy. In Journal of Legislative Studies, 6:1, 32-58

Deegan-Krause K. (2007). New dimensions of political cleavage, in Dalton R., Klingemann H.-D. (eds). The Oxford Handbook of Political Behaviour. Oxford: Oxford University Press

De la Porte C., Pochet P. (2001). Pension reform at the European level: actors, discourses, outcomes. Paper prepared for the biannual meeting of the European Communities Study Association. Wisconsin

De Menil G., Sheshinski E. (2002) Romania's pension system. From crisis to reform, in Feldstein M., Siebert H. (eds). Social security pension reform in Europe. National Bureau of Economic Research: University of Chicago Press

De Ruiter R. (2010). EU soft law and the functioning of representative democracy: the use of method of open coordination by Dutch and British parliamentarians, in Journal of European Public Policy, 17:6, 874890

De Ruiter R. (2011). The national parliamentary arena and methods of open coordination: explaining the frequency of OMC related executive-legislative interactions, in Journal of Contemporary European Research, 7:1, 101-119

De Ruiter R. (2014). Under the radar? National parliaments and the ordinary legislative procedure in the European Union, in the Journal of European Public Policy, 20:8, 1196-1212.

De Vries C.E. (2007). Sleeping giant: Fact or fairytale? How European integration affects national elections, in European Union Politics, 8:3, 363-385

De Vries C.E., Tillman E.R. (2011). European Union issue voting in East and West Europe: The role of political context, in Comparative European Politics, 9:1, 1-17

Desposato S. (2012). Book review. The Handbook of National Legislatures, in Legislative Studies Quarterly, 37:3, 389-396

De Wilde P. (2007) Politicization of European integration: bringing the process into focus. ARENA Working Papers № 18 .

De Wilde P. (2008) Media coverage and national parliaments in EU policy formulation: Debates on the EU budget in the Netherlands 1992-2005, in RECON Working Paper Series, 13/3008

De Wilde P. (2011a). No effect, weapon of the week or reinforcing executive dominance? How media coverage affects national parliaments' involvement in EU policy formulation, in Comparative European Politics, 9:2, 123-144

De Wilde P. (2011b). Ex ante vs. ex post: the trade-off between partisan conflict visibility in debating EU policy-formulation in national parliaments, in Journal of European Public Policy, 18:5, 672-689

Detterbeck K. (2005). Cartel parties in Western Europe?, in Party politics, 11:2, 173-191

Dexter L. (1970). Elite and specialized interviewing. Evanston: Northwestern University Press

Dimitrakopulos D. (2001). Incrementalism and path-dependence: European Integration and Institutional Change in National Parliaments, in Journal of Common Market Studies, 39:3, 405-422

Dinan D. (2010). Institutions and governance: A new Treaty, a newly elected parliament and a new commission, in Journal of Common Market Studies, 48: s1, 95-118

Dobbels, M., Neuhold, C. (2013) “The Roles Bureaucrats Play': The Input of European Parliament (EP) Administrators into the Ordinary Legislative Procedure: A Case Study Approach', Journal of European Integration, 35:4, 375-390

Döring H. (1995) Parliaments and majority rule in Western Europe. Mannheim: Mannheim center for European Social Research

Döring H.(2001). Parliamentary agenda control and legislative outcomes in Western Europe, in Legislative Studies Quarterly, 26:1, 145-165

Dowding K., Peter J., Mergoupis T., van Vugt T. (2000). Exit, voice and loyalty: analytic and empirical developments, in European Journal of Political Research, 37:4, 469-495

Down I., Wilson C.J. (2008). From permissive consensus to constrained consensus: A polarizing Union?, in Acta Politica, 43:1, 26-49 
Duchesne S. (2010). Europe between integration and globalization: Social differences and national frames in the analysis of focus groups conducted in France, Francophone Belgium and the United Kingdom, in Politique européenne, 30:1, 67-106

Dudek C., Omtzigt P. (2001). The role of Brussels in national pension reform, in EUI Working Paper №47. Florence

Duina F., Oliver M. (2005). National parliaments in the European Union: Are there any benefits to integration? European Law Journal, 11:2, 173-195

Duina F, Raunio T. (2007). The open method of coordination and national parliaments: further marginalization or new opportunities, in European Public Policy, 14:4, 489-506

Dür A. (2008). Measuring Interest Group Influence in the EU: A Note on Methodology, European Union Politics, 9:4, 559-576

Earles K. (2009). The gender effects of the Swedish pension reform, Paper presented at the Canadian Political Science Association annual conference, May 27-29 2009, Carleton University, Canada

Ebbinghaus B., Gronwald (2010). The changing public-private pension mix in Europe: From path dependence to path departure, in Ebbinghaus B. (ed.) The varieties of pension governance. Pension privatization in Europe. Oxford: Oxford University Press

Eckardt M. (2005). The open method of coordination on pensions: an economic analysis of its effects on pension reform, in Journal of European Social Policy, 15:3, 247-267

ECPRD (2003). European Affairs Committees. The influence of National parliaments on European policies. Brussels.

EFRP (2009). Facing up to challenges. EFRP CEEC Forum. Budapest Conference Report.

Egeberg M., Gornitzka Å, Trondal J., Johannessen M. (2013). Parliamentary staff: unpacking the behaviour of officials in the European Parliament, in Journal of European Public Policy, 20:4, 495-514

Elgie R., Stapleton J. (2006). Testing the decline of parliament thesis: Ireland, 1923-2002, in Political Studies, $54: 3,465-485$

EMN (2011). Satisfying labour demand through migration. EMN Report

Eneydi Z. (2008). The social and attitudinal basis of political parties: cleavage politics revisited, in European Review, 16:3, 287-304

Enyedi Z., Deegan-Krause K. (2011). The structure of political competition in Western Europe. L.: Routledge

EPC, EGMONT, CEPS (2007). National Parliaments and the Subsidiarity Principle, in The Treaty of Lisbon: Implementing the Institutional Innovations : EPC, EGMONT, CEPS Joint Study.

Eriksen, E.O., Fossum J.E. (eds). (2000). Democracy in the European Union: Integration through deliberation. L., N.Y.: Routledge

Evans A.C. (1981). Participation of national parliaments in the European Community legislative process, in Public Law, 388-398

Fabbrini F., Granat K. (2013). "Yellow card, but no foul": The role of the national parliaments under the subsidiairty protocol and the commission proposal for an EU regulation on the right to strike, in Common Market Law Review, 50:1, 115-143

Fasone C. (2014). European economic governance and parliamentary representation. What place for the European Parliament?, in European Law Journal, 20:2, 146-185

Ferrera M. (2009). The JCMS Annual lecture: national welfare states and European Integration: in search of a "virtuous nesting", in Journal of Common Market Studies, 47:2, 219-233

Flinders M., Kelso A. (2011). Mind the gap: Political analysis, public expectations and the parliamentary decline thesis, in British Journal of Politics and International Relations, 13:2, 249-268

Fish M., Kroenig S. (2009). The handbook of national parliaments. A global survey. Cambridge: Cambridge University Press

Flyvbjerg B. (2011). Case studies, in Denzin N.K., Lincoln Y.S. (eds). The SAGE Handbook of qualitative research. L.: SAGE

Follesdal A., Hix S. (2006). Why there is a democratic deficit in the EU: A response to Majone and Moravcsik, in Journal of Common Market Studies, 44:3, 533-562

Fraga A. (2005). After the Convention: The future role of the National parliaments in the European Union (and the day after...nothing will happen, in the Journal of Legislative Studies, 11:3, 490-507 
Franklin M. (2010). Cleavage research: A critical appraisal, in West European Politics, 33:3, 648-658

Fujimura N. (2012). Electoral incentives,, party discipline and legislative organization: manipulating legislative committees to win elections and maintain party unity, in European Political Science Review, 4:2, $147-175$

Gailmard S., Patty J. (2007). Slackers and Zealots: Civil Service, Policy Discretion, and Bureaucratic Expertise, in American Journal of Political Science, 51:4, 873-889

Gattermann K., Högenauer A.-L., Huff A. (2013) A new phase of Europeanisation of national parliaments: Towards mainstreaming of EU affairs? Paper presented at the EUSA conference in Baltimore, 9-11 May 2013

George A., Bennett A. (2005). Case studies and theory development in social sciences. Massachussets: Harvard University

Gerring J. (2007). Case study research. Principles and practices. Cambridge: Cambridge University Press

Ghinea C., Dinu D., Tănăsache O. (2010). The Romanian Parliament enters the EU. The challenge of being an active actor in Europe. CRPR, Friedrich Ebert Stiftung: Bucharest

Goetz K. H., Meyer-Sahling J.-H. (2008). The Europeanisation of national and political systems: Parliaments and executives, in Living Reviews in European Governance, 3:2

Gomm R., Hammersley M., Foster P. (2000) Case study and generalization, in Gomm R., Hammersley M., Fioster P. (eds). Case study method. Key issues, Key texts. SAGE: L.

Green-Pedersen C. (2012). A giant fast asleep? Party incentives and the politicization of European integration, in Political Studies, 60:1, 115-130

Green-Pedersen C. (2010). Bringing parties into parliament: The development of parliamentary activities. in Western Europe, in Party Politics, 16:3, 347-369

Green-Pedersen C., Lindbom A. (2006). Politics with paths: trajectories of Danish and Swedish earningsrelated pensions, in Journal of European Social Policy, 16:3, 245-258

Gros D., Steinherr A. (2004). Economic transition in Central and Eastern Europe. Planting the seeds. Cambridge: Cambridge University Press

Grossman E., Sauger N. (2007). Political institutions under stress? Assessing the impact of European integration on French political institutions, in Journal of European Public Policy, 14:7, 1117-1134

Grzelak A. (2014). Scrutiny of the European Commission's legislative proposals by national parliaments example of COM (2010) 10 on data protection in cooperation in criminal matters. PADEMIA Online papers in parliamentary democracy. №1.

Guardiancich I. (2009). Pension reform in Central, Eastern and South-Eastern Europe: Legislation, implementation and sustainability. EUI PhD thesis. Department of political and social sciences. Florence

Guardiancich I. (2011). Pan-European pension funds: current situation and future prospects, in International Social Security Review, 64:1, 15-36

Guasti P. (2011). The Europeanisation of parliaments in Central and Eastern Europe, in RECON Online working papers 11

Guiraudon V. (2000). European integration and migration policy: vertical policy-shaping as venue shopping, in Journal of Common Market Studies, 38:2, 251-271

Gustavsson S. (1996). Preserve or abolish the democratic deficit?, in Smith E. (ed). National parliaments as cornerstones of European integration. L.: Kluwer Law International

Haegel F. (2008). Le "parti-cartel" de la logique interne à la validité empirique, in Aucante Y., Dézé A. (eds). Les systèmes de parties dans les démocraties occidentals. Le modèle du parti-cartel en question. Sciences Po Les Presses: Paris

Hamerly I. (2007). A matter of timing: Explaining cross-national variation in the parliamentary oversight of European Union Affairs. PhD Dissertation. University of California, San Diego. Unpublished manuscript

Hansen T.B., Scholl B. (2002) Europeanization and domestic parliamentary adaptation A comparative analysis of the Bundestag and the House of Commons, in European Integration online Papers (EIoP), 6:15

Harlow C. (2002) Accountability in the European Union. Oxford: Oxford University press

Haughton T., Novotna T., Deegan-Krause K. (2011). The 2010 Czech and Slovak parliamentary elections: Red cards to the "winners", in West European Politics, 34:2, 394-402 
Hawkins D. (2009). Case studies, in Landman T., Robinson N. (eds.) The SAGE handbook of Comparative Politics. SAGE: L.

Hegeland H. (2011). The European Union as a foreign policy or domestic policy? EU affairs in the Swedish Riksdag, in Persson T., Wiberg M. (eds). Parliamentary government in the Nordic countries at a crossroads. Coping with challenges from Europeanisation and Presidentialisation. Stockholm: Santerus Academic Press

Hegeland H. (2015). The Swedish parliament and EU affairs: from reluctant player to Europeanized actors, in Hefftler C., Neuhold C., Rozenberg O., Smith J., Wessels W. (eds.) Palgrave handbook of national parliaments and the European Union. L.: Palgrave

Hegeland H., Mattson I. (1996). To have a voice in the matter: A comparative study of the Swedish and Danish European Committees, in Journal of Legislative Studies, 2:3, 198-215

Hegeland H., Mattson I. (2000). Another link in the chain: The effects of EU membership on delegation and accountability in Sweden, in Journal of Legislative Studies, 6:1, 81-104

Hegeland H., Neuhold C. (2002) Parliamentary participation in EU affairs in Austria, Finland and Sweden: Newcomers with different approaches, European Integration online Papers, 6:10

Héritier A. (2008). Causal explanation, in della Porta D., Keating M. (eds) Approaches and methodologies in the social sciences. A pluralist perspective. N.Y.: Cambridge University Press

Herman V., van Schendelen R. (1979). The European Parliament and the national parliaments. Westmead, Saxon House

Herranz-Surrallés A. (2014). The EU's multi-level parliamentary (battle)field: inter-parliamentary cooperation and conflict in foreign and security policy, in West European Politics, 37:5, 957-975

Hirschman A. (1970). Exit, Voice, and Loyalty: Responses to decline in firms, organizations, and states. Harvard University Press

Hirschman A. (1980). Exit, voice and loyalty: further reflections and a survey of recent contributions, in The Milbank Memorial Fund Quarterly. Health and Society, 58:3, 430-453

Hix S. (1999). Dimensions and alignments in European Union politics: cognitive constraints and partisan responses, in European Journal of Political research, 35:1, 69-106

Hix S., Raunio T. (2001). Backbenchers learn to fight back: European integration and parliamentary government, in Goetz Klaus, Hix Simon (eds). Europeanised politics? European integration and national political systems. L.: Frank Cass Publishers

Hlousek V., Pseja P. (2009). Europeanization of political parties and party system in the Czech Republic, in Journal of Communist Studies and Transition Politics, 25:4, 513-539

Hörner, J. (2013). The determinants of debate on EU affairs in national parliaments: A quantitative perspective, Paper presented at the EUSA $13^{\text {th }}$ biennial conference, May 9-11, Baltimore

Högenauer A.-L, Neuhold C. (2013). National parliaments after Lisbon: administrators on the rise? OPAL Online Paper Series. № 12

Höing O. (2013). Differentiation of parliamentary powers. The German Constitutional Court and the German Bundestag within the financial crisis, in Cartabia M., Lupo N., Simoncini A. (eds) Democracy and subsidiarity in the EU. National parliaments, regions and civil society in the decision-making process. Società editrice il Mulino: Bologna

Holzhacker R. (2002). National parliamentary scrutiny over EU issues. Comparing the goals and methods of government and opposition parties , in European Union Politics, 3:4, 459-479

Holzhacker R. (2005). The power of opposition parliamentary groups in European scrutiny, in Journal of Legislative Studies, 11:3-4, 428-445

Holzhacker R. (2008). Parliamentary scrutiny, in Graziano P., Vink Maarten P. (eds). Europeanization. New research agendas. L.: Palgrave

Holzhacker R., Albaek E., (eds) (2007). Democratic governance and European Integration: Linking societal and state processes of democracy. Cheltenham: Edward Elgar Publishing

Holzman R., Guven U. (2009). Adequacy of retirement income after pension reforms in Central, Eastern and Southern Europe. N.Y: IBRD, World Bank

Holzman R., Hinz R. (2005). Old age income support in the $21^{\text {st }}$ century. An international perspective on pension systems and reform. Washington: The World Bank 
Hurrelmann A. (2007). European democracy, the "permissive consensus" and the collapse of the EU Constitution, in European Law Journal, 13:3, 343-359

Iglesias G., Blanco L. (eds) (2010). The role of national parliaments in the European Union. FIDE XXIV Congress. Madrid

Immergut E., Anderson K.M., Schulze I. (2007). The handbook of West European pension politics. Oxford: Oxford University Press

Inter - Parliamentary Union (2012). Global parliamentary report. The changing nature of parliamentary representation. IPU, UNDP.

Ionescu I. (2011). Le rôle du Parlement dans la création des politiques publiques en Roumanie postcommuniste. Bucharest: Instituttul European.

Isberg M. (2011). Is Sweden going majoritarian?, in Persson T., Wiberg M. (eds). Parliamentary government in the Nordic countries at a crossroads. Coping with challenges from Europeanisation and Presidentialisation. Stockholm: Santerus Academic Press

Jančić D. (2010). The Portuguese Assembly of the Republic: From democratic consolidation to European participation? Paper presented at the $5^{\text {th }}$ Pan-European Conference on EU politics. University of Oporto and University Fernando Pessoa. Porto, Portugal, 24-26 June 2010

Jans T., Pedrafita S. (2009). The role of national parliaments in the European Union decision-making, in EIPASCOPE, №1

Jensen J. (2008). Political accountability in Denmark, in Verhey L., Kiiver P., Loeffen S. (eds.) Political accountability in Europe: Which way forward? Groningen: Europa Law Publishing

Jensen J., Pochet P. (2002). Employment and social policy since Maastricht: Standing up to the European Monetary Union. Institut d'études européennes/ Université de Montrèal Research Paper ${ }^{1}$ 06/02

Johansson K., Tallberg J. (2010). Explaining chief executive empowerment: EU summitry and domestic institutional change, in West European Politics 33:2, 208-236

Johansson K., Raunio T. (2001). Partisan responses to Europe: Comparing Finnish and Swedish political parties, in European Journal of Political research, 39:2, 225-249

Judge David (1995). The failure of national parliaments?, in Hayward Jack (ed). The crisis of representation in Europe, L.: Frank Cass

Jungar A.-C. (2009). The choice of parliamentary EU scrutiny mechanisms in new EU member-states, in Jacobsson B. (ed.). The European Union and the Baltic states: changing forms of governance. L.: Routledge

Kamann H.-G. (1997). Die Mitwirkung der Parlamente der Mitgliedstaaten an der europäischen Gesetzgebung. Frankfurt am Mein: Peter Lang

Kangas O., Lundberg U., Ploug N. (2006). Three routes to a pension reform. Politics and institutions in reforming pensions in Denmark, Finland and Sweden. Stockholm: Institute for Future Studies

Karlas J. (2011). Parliamentary control of EU affairs in Central and Eastern Europe, in Journal of European Public Policy, 18:2, 258-273

Karlas J. (2012). National parliamentary control of EU affairs: Institutional design after enlargement, in West European politics, 35:5, 1095-1113

Katz R., Mair P. (1995). Changing models of party organization and party democracy: the emergence of the cartel party, in Party Politics, 1:1, 5-28

Katz R., Mair P. (2002). The ascendancy of the party in public office: party organizational change in twentieth century, in Gunther R., Montero J.R., Linz J.J. (eds). Political parties: Old concepts and new challenges. Oxford: Oxford University Press

Katz R., Mair P. (2009). The cartel party thesis: a restatement, in Perspectives on politics, 7:4, 753-766

Kelso A. (2007). Parliament and political disengagement: neither waving, nor drowning, in the Political Quarterly, 78:3, 364-373

Kemper E.A., Stingfield S, Teddlie C. (2003). Mixed methods sampling strategies in social science research, in Tashakkori A., Teddlie C. (eds.) Handbook of mixed methods in social and behavioural research. SAGE: Thousand Oaks

Kietz D. (2006). What accounts for national divergence: the Baltic states in EU affairs. Paper presented at the EU-Consent PhD Summer School, Budapest, May 2006 
Kiiver P. (2006a). The composite case of national parliaments in the European Union: who profits from enhanced involvement, European Constitutional Law Review, 2:2, 227-252

Kiiver P. (2006b). The national parliaments in the European Union: A critical view on the EU constitutionbuilding. Hague: Kluwer Law International

Kiiver P. (2009). German participation in the EU decision-making after the Lisbon case: A comparative view on domestic parliamentary clearance procedures, in German Law Journal, 10:8, 1287-1296

Kiiver P. (2011). The early-warning system for the principle of subsidiarity: The national parliament as a Conseil d'État for Europe, in European Law Review, 36:1, 98-108

Kiiver P. (2012). The early warning system for the principle of subsidiarity. Constitutional theory and empirical reality. L. Routledge.

King A. (1976). Modes of executive-legislative relations: Great Britain, France and West Germany, in Legislative Studies Quarterly, 1:1, 11-36

Kitschelt H. (2000). Citizens, politicians, and party cartelization: Political representation and state failure in post-industrial democracies, in European Journal of Political Research, 37:2, 149-179

Kroenig M., Fisch S. (2012). A response to Desposato, in Legislative Studies Quarterly, 37:3, 397-401

Knutelska V. (2011). Working practices winning out over formal rules: Parliamentary scrutiny of EU matters in the Czech Republic, Poland and Slovakia, in Perspectives on European Politics and Society, 12:3, 320-339

Knutsen O., Scarborough E. (1995). Cleavage politics, in van Deth J., Scarborough E. (eds.). The impact of values. Oxford: Oxford University Press

Kolarska-Bobinska L. (2003). The EU accession and strengthening of institutions in East Central Europe: The Case of Poland, in East European Politics and Societies, 17:1, 91-98

Könberg B., Palmer E., Sundén A. (2006). The NDC reform in Sweden: The 1994 legislation to the present, in Holzmann R., Palmer E. (eds). Pension reform. Issues and prospects for Non-financial defined contribution (NDC) schemes. Washington: IBRD

König T., Mäder L. (2012) Going beyond: causes of Europeanization, in Brouard S., Costa O., König T. (eds.) The Europeanization of domestic legislatures. The empirical implications of the Delors' myth in nine countries. N.Y.: Springer

Koole R. (1996). Cadre, catch-all or cartel? : A comment on the notion of the cartel party, in Party Politics, 2:4, 507-523

Kopecký P. (2001). Parliaments in the Czech and Slovak Republics. Party competition and parliamentary institutionalization. Aldershot: Ashgate

Kopecký P. (2007). Structures of representation, in White S., Batt I., Lewis G.Paul (eds.) Developments in Central and Eastern European Politic 4.L.: Palgrave

Král D., Bartovic V. (2010). The Czech and Slovak parliaments after the Lisbon Treaty. Prague: EUROPEUM Institute for European Policy

Kratz S., von Steinsdorff S. (Hrsg.) (2002). Parlamente und Systemtransformation im post-sozialistischen Europa. Opladen, Leske und Budrich

Krehbiel K. (1991). Information and legislative organisation. Ann Arbor: University of Michigan Press

Kriesi H. et al (2008). West European Politics in the age of globalization. Cambridge: Cambridge University Press.

Kriesi H. (2007). The role of European integration in national election campaigns, in European Union Politics, 8:1, 83-108

Kröger S., Friedrich S. (2013). Introduction: the representative turn in EU studies, in Journal of European Public Policy, 20:2, 155-170

Krogh S. (2011). Reform politics through the creation of inefficient political institutions: The case of the 2007 Danish administrative reform, in Scandinavian Political Studies, 34:4, 307-331

Kroenig M., Fish M. (2009). A handbook of national legislatures. A global survey. Cambridge: Cambridge University Press

Kroenig M., Fisch M.(2012). A response to Desposato, in Legislative Studies Quarterly, 37:3, 397-401 
Kropp S. (2008) Capacity building of parliamentary party groups in the German and Hungarian parliaments: Institutions and cognitions in the Europeanized policy-making process. Paper presented at $21^{\text {st }}$ IPSA World Congress "Global discontent? Dilemmas of change". Santiago, Chile, 12-16 July

Kropp S., Buche J., Buzogány A. (2011). Parlamentarisch-exekutive Steuerung in europäischen Fachpolitiken ein Blick auf die Mikroebene, in Abels G., Eppler A. (Hrsg.) Auf dem Weg zum Mehrebenparlamentarismus? Funktionen von Parlamenten im politischen System der EU. Baden-Baden: Nomos Verlag

Krunke H. (2007). Developments in national parliaments' involvement in ordinary foreign policy and European policy, in European Public Law Journal, 13:2, 335-348

Kvale S. (2007). Doing interviews. L: SAGE Publications

Ladrech R. (2002). Europeanization and political parties: Towards a framework for analysis, in Party Politics, $8: 4,389-403$

Ladrech R. (2007). National political parties and European governance: The consequences of "missing in action", in West European Politics, 30:5, 945-960

Ladrech R. (2009). Europeanisation and political parties, in Living Reviews in European Governance, 4:1

Ladrech R. (2010). Europeanization and National Politics. L.Palgrave

Ladrech R. (2012). Party change and Europeanisation: Elements of an integrated approach, in West European Politics, 35:3, 574-588

Laprat G. (1995). Réforme des Traités : Le risque du double déficit démocratique, in Revue du Marché Commun, 351, 710-721

Larhant M. (2005). La cooperation interperlementaire dans l’UE. Notre Europe Policy Paper №16.

Laprat G. (1995). Parliamentary scrutiny of Community Legislation: An evolving Idea, in Laursen F., Pappas S. (eds). The Changing Role of Parliaments in the European Union, Maastricht: EIPA

Larue T. (2011). Post-Lisbon subsidiarity scrutiny and Nordic parliamentary government: Challenges and opportunities of Europeanization, in Persson T., Wiberg M. (eds.) Parliamentary government in the Nordic countries at a crossroads. Coping with challenges from Europeanisation and Presidentialisation. Stockholm: Santerus Academic Press

Laumen A., Maurer A. (2006). Jenseits des "Permissive Consenus". Bevölkerungsorientierung gegenüber Europäischen Integration im Wandel?, SWP Diskussionspapier. Berlin

Laursen, F., Pappas S. (eds) (1995) The changing role of parliaments in the European Union. Maastricht: European Institute of Public Administration

Laursen F. (2005). The role of national parliamentary committees in European scrutiny: Reflections based on the Danish case, in Journal of Legislative Studies, 11:3-4, 412-427

Leston-Bandeira C. (2012). Studying the relationship between Parliament and citizens, in Journal of Legislative Studies, 18:3-4, 265-274

Lilleker D. (2003). Interviewing the political elite: Navigating a potential minefield, in Politics, 23:3, 207-214

Lindberg L, Scheingold S. (1970) Europe's would-be polity. Englewood Cliffs: Prentice-Hall

Lindquist G., Wadensjö E. (2010). Sweden: a viable public-private pension system, in Ebbinghaus B. (ed). The varieties of pension governance. Oxford: Oxford University Press

Lisický M. (2003). Pension reform in the Czech Republic: A gradual approach, in Focus on Transition, 1, 174-188

Littig B. (2009). Interviewing the elite - interviewing experts: is there a difference, in Bogner A., Littig B., Menz W. (eds). Interviewing experts. N.Y.: Palgrave Macmillan

Lodge M. (2007). Comparing non-hierarchical governance in action: the Open Method of Co-ordination in pensions and information society, in Journal of Common Market Studies, 45:2, 343-365

Lord C. (2007). Contested meanings, democracy assessment and the European Union, in Comparative European Politics, 5:1, 70-86

Loxbo. K. (2013). The fate of intra-party democracy: Leadership autonomy and activist influence in the mass party and the cartel party, in Party Politics, 19:4, 537-534

Maatsch A. (2010). Between an Intergovernmental and a Polycentric European Union: National Parliamentary Discourses on Democracy in the EU Ratification Process. RECON Online Papers 2010/18 
Maatsch A. (2014). Are we all austerians now? An analysis of national parliamentary parties' positioning on anti-crisis measures in the Eurozone, in Journal of European Public Policy, 21:1, 96-115

Mabbett D. (2009). Supplementary pensions between social policy and social regulation, in West European Politics, 32:4, 774-791

Mácha M. (2002). The political economy of the pension reform in the Czech republic, in Fulz E. (ed.) Restructuring the public pension schemes: case studies of the Czech republic and Slovenia. Pension reform in Central and Eastern Europe. Vol, 2

Magone J. (2011). Contemporary European Politics. A Comparative Introduction. Oxon: Routledge

Mahoney J. (2000). Path dependence in historical sociology, in Theory and Society, 29:6, 507-548

Mair P. (2005). Popular democracy and the European Union. European Governance paper № C-05-03

Mair P. (2006). Ruling the void? The hollowing of Western democracy, in New Left Review, 42, 25-51

Mair P. (2007). Political opposition and the European Union, in Government and Opposition, 42:1, 1-17

Mair P. (2008). Political parties and party systems, in Graziano P., Vink M. (eds). Europeanization. New research agendas. L.:Palgrave Macmillan

Mansfeldova Z.(2004). The politics between parliament and government the institutional framework and the reality within the Czech parliament, in Mansfeldova Z., Olson D., Rakušanova P. (eds). Central European parliaments. "The first decade of democratic experience and future perspectives. Prague: Institute of Sociology, Academy of Sciences of the Czech Republic

Mansfeldova Z. (2005). Executive-legislative relations in the budgeting process in the Czech republic, in Czech Sociological review, 41:3, 443-460

Mansfeldova Z., Olson D. M., Rakušanova P. (eds) (2004) Central European parliaments: The first decade of democratic experience and future perspectives. Prague: Institute of Sociology, Academy of Sciences of the Czech Republic

Marier P. (2008). Pension politics. Consensus and conflict in ageing societies. L.: Routledge

Marks G., Wilson C.J. (2001). The past in the present: A cleavage theory of party responses to European integration, in British Journal of Political Science, 30:3, 433-459

Martin L.W., Vanberg G. (2011). Parliaments and coalitions. The role of legislative institutions in multiparty governance. Oxford: Oxford University Press

Martino N. (2006). Balancing power: Committee system autonomy and legislative organization, in Legislative Studies Quarterly, 31:2, 205-234

Mastenbroek E., Spendzharova A., Versluis E. (2014). Clawing back lost powers? Parliamentary scrutiny of the transposition of EU social policy directives in the Netherlands, in West European Politics, 37:4, $750-768$

Mateescu S.-D. (2010) The cartelization of the Romanian party system: A case study. Paper presented at the $20^{\text {th }}$ ECPR Summer school "Political parties in modern democracies", Brussels, 13-25 September 2010

Mattila M., Raunio T. (2012). Drifting further apart: National parties and their electorates on the EU dimension, in West European Politics, 35:3, 589-606

Matilla M., Raunio T. (2006). Cautious voters-supportive parties. Opinion congruence between voters and parties on the EU dimension, in European Union Politics, 7:4, 427-449

Maurer A. (2001). National parliaments after Amsterdam: Adaptation, re-calibration and Europeanisation by process. Paper for Working Group Meeting XXIVth COSAC, April 8-9

Maurer A., Kietz D. (2004). Die neuen Rechte der nationalen Parlamente: Umsetzungsprobleme und Empfehlungen. SWP Diskussionspapier

Maurer A., Wessels W. (eds) (2001). National parliaments on their ways to Europe: Losers or latecomers? Baden-Baden: Nomos

Manzella A. (2009). The role of parliaments in the democratic life of the Union, in Micossi S., Tosato G.L. (eds) Europe in the $21^{\text {st }}$ century: Perspectives from the Lisbon Treaty. Brussels: CEPS

Marier P. (2008). Pension politics. Consensus and social conflict in ageing societies. N.Y.: Routledge

McGann A.J. (2006). Social choice and comparing legislatures: Constitutional versus institutional constraints, in Journal of Legislative Studies, 12:3-4, 443-461

McLoughin S., Münz R. (2011). Temporary and circular migration: opportunities and challenges. EPC Working Paper 
Melia T. (2010). What makes legislatures strong, in Journal of Democracy, 21:2, 166-170

Menz G. (2011). Stopping, shaping and moulding Europe: two-level games, non-state actors and the Europeanization of migration policies, in Journal of Common Market Studies, 49:2, 437-462

Meyer T., Bridgen P. (2007). Private pensions versus social inclusion? Non-state provisions for citizens at risk in Europe. Cheltenham: Edward Elgar

Mezey M. (1979) Comparative legislatures. Durham NC: Duke University Press

Miklin E. (2011). Inter-parliamentary cooperation in EU affairs and the Austrian Parliament: Empowering the opposition?, Paper presented at the $6^{\text {th }}$ ECPR General Conference, Reykjavik, 25-27

Moe T. (2005). Power and political institutions, in Perspectives on politics, 3:2, 215-233

Moe T. (1990). Political institutions: The neglected side of the story, in Journal of Law, Economics \& Organization, 6:213-253

Mood C. (2011). Lagging behind in good times: immigrants and the increased dependence on social assistance in Sweden, in International Journal of Social Welfare, 20:1, 55-65

Moravcsik A. (1994). Why the European Community strengthens the state: democratic policies and international cooperation, in Center for European Studies Working Paper Series. № 52

Müller K. (1999). The political economy of pension reform in Central-Eastern Europe. Cheltenham, Northampton: Edward Elgar.

Müller K. (2003). Pension reform in the East European accession counties, in European Journal of Social Security, 5:1, 7-37

Mudrack G. (2006). The current tax situation of occupational pensions and pan-European pension funds, in Journal of business economics and management, 7:1, 45-49

Nanou K., Dorussen H. (2013). European integration and electoral democracy: How the European Union constrains party competition in the member states, in European Journal of Political research, 52:1, 7193

Natali D. (2004). The hybridization of pension systems within the enlarged EU: recent reforms in old and new members, in Revue belge de securité social, 2, 353-377

Natali D. (2007). Pensions OMC: why did it emerge and how does it evolve. Paper for the Annual EUSA conference. Montreal

Natali D.(2008). Pensions in Europe, European pensions. The evolution of pension policy at national and supranational level. Bruxelles: Peter Lang

Natali D. (2009). The Open Method of Cooperation on pensions: Does it de-politicise pension policy?, in West European Politics, 32,4, 810-828

Nentwich M. (1996) Opportunity structures for citizen participation: The case of the European Union, in European Integration online Papers (EIoP), 1

Netjes C., Binnema H. (2007). The salience of the European integration issue: Three data sources compared, in Electoral studies, 26:1, 39-49

Neuhold C. (2003). Competitors in the same boat? Parliamentary involvement at the European Convention. Paper presented at the panel "The Convention and the future of the European Union", EUSA Conference, Nashville, Tennessee, 27-29 March

Neuhold C. (2011). Late wake-up call or early warning? Parliamentary participation and cooperation in the light of the Lisbon Treaty. Paper presented for the UACES Conference: The Lisbon Treaty evaluated: Impact and consequences. L., 31 January-1 February

Neuhold C., de Ruiter R. (2010). Out of REACH? Parliamentary control of EU affairs in the Netherlands and the UK, in Journal of Legislative Studies, 16:1, 57-72

Neuhold C., Dobbels M. (2014). Paper keepers or policy-shapers? The conditions under which EP officials impact on the EU policy process, in Comparative European Politics, advance online publication

Neuhold C., Smith J. (2015). Conclusion: From 'latecomers' to 'policy-shapers'? - The role of national parliaments in the 'post-Lisbon' Union, in Hefftler C., Neuhold C., Rozenberg O., Smith J., Wessels W. (eds.) Palgrave handbook of national parliaments and the European Union. L.: Palgrave

Neuhold C., Strelkov A. (2012). New opportunity structures for the new kids in the block? Implications of the early warning System (EWS) for the role of national parliaments within the EU system of governance. OPAL working papers №4. 
Neunreither K. (1994). The democratic deficit of the European Union: Towards closer cooperation between the European parliament and the National parliaments, in Government and Opposition, 29:3, 299-314

Neunreither K. (2005). The European Parliament and national parliaments: conflict or cooperation, in Journal of Legislative Studies, 11:3-4, 466-489

Neunreither K. (2006). Elected legislators and their unelected assistants in the European Parliament, in Journal of Legislative Studies, 8:4, 40-60

Neuvonen M. (2007). National parliaments and the EU policy-making: A comparative study of the EU, Finland, Poland and Estonia. University of Bristol. $\mathrm{PhD}$ dissertation. Unpublished manuscript

Niblock M. (1971). The EEC: National parliaments in community decision-making. L.: Chatham House

Norris P. (1997). Representation and the democratic deficit, in European Journal of Political Research, 32:2, 273-282

Norton P. (1995). Conclusion: addressing the democratic deficit, in Journal of Legislative Studies, 1:3, 177 193

Norton P. (ed). (1996). National parliaments and the European Union. L.: Frank Cass

Norton P. (1998). Parliaments and governments in Western Europe. L.: Frank Cass

Nowaczek K. (2008). Extending the equality principle to non-EU migrants: Analyzing the proposal for a directive on rights for third-country workers, in European Governance, 2:2, 6-19,

Öberg S. Jungar A.-C., (2004). Are national parliaments lagging behind? The influence of the Swedish and Finnish Parliaments over domestic EU politics, in Agh A. (ed). Post-accession in East Central Europe: The emergence of EU 25. Budapest: Hungarian Center for Democracy Studies

Öberg A.S., Jungar A.-C. (2009). The influence of national parliaments over domestic European Union policies, in Scandinavian Political Studies, 32:4, 359-381

O’Brennan J., Raunio T. (2007). National parliaments within the enlarged European Union. L.: Routldege

OECD (2011). Recruiting immigrant workers. Sweden. OECD Publishing

Olson M.D., Ilonszki G. (2011). Two decades of divergent post-communist parliamentary development, in Journal of Legislative Studies, 17:2, 234-255

Olson D.M.., Norton P. (eds) (1996). The New Parliaments of Central and Eastern Europe. L., Portland: Frank Cass

Olson D. M., Norton P. (eds) (2007) Journal of Legislative Studies. Special Issue: Post-Communist and PostSoviet Legislatures: Beyond transition. Vol.13, 1

Orenstein M. (2011). Pension privatization in crisis: Death or rebirth of a global policy trend?, in International Social Security Review, 64:3, 65-80

Ostrander S. (1993). Surely you are not in this just to be helpful, in Journal of Contemporary Ethnography, $22: 1,7-27$

Pahre R. (1997). Endogenous domestic institutions in two-level games and parliamentary oversight of the European Union, in Journal of Conflict Resolution, 41:1, 147-174

Palmer E. (2002). Swedish pension reform. How did it evolve, and what does it mean for the future?, in Feldstein M., Siebert H. (eds). Social security pension reform in Europe. Chicago, L.: University of Chicago Press

Papadimitrou D., Phinnemore D. (2008). Romania and the European Union: From marginalization to membership. L.:Palgrave, 2008

Pélassy D. (1994). Le Déclin du Parlement en Europe, in Flinterman C., Heringa A., Wadington L. (eds). The Evolving Role of Parliaments in Europe. Antwerpen, Apeldoorn: MAKLU, NOMOS

Pelizzo R. (2008). Cartel parties and cartel party systems: The rise of irresponsible government. Säarbrücken, Germany: VDM Verlag Dr Müller Aktiengessellschaft

Pennings P. (2006). An empirical analysis of the Europeanization of national party manifestos, 1960-2003, in European Union Politics, 7:2, 257-270

Peters D., Wagner W., Deitelhoff N. (eds). (2008). The parliamentary control of European security policy. ARENA report № 7.2008

Peters D., Wagner W., Glahn C. (2011). Parliamentary control of military missions. The case of the EU Navfor Atalanta. RECON Online Working Paper 2011/24 
Peters D., Wagner W. and Deitelhoff N. (2010). Parliaments and European Security Policy: Mapping the Parliamentary Field, in Vanhoonacker S., Dijkstra H. and Maurer H. (eds). Understanding the Role of Bureaucracy in the European Security and Defense Policy, European Integration online Papers (EIoP), Special Issue 1, Vol.14

Peters G. (1998). Comparative politics: theory and methods. N.Y.: MacMillan

Peters G., Pierre J. (2004). The politicization of the civil service in comparative perspective. L.: Routledge

Peters J. (2008). The role of national parliaments. Checks and balances between the EU and the member states, in Verhe L., Kiiver P., Loeffen S. (eds). Political accountability in Europe: Which way forward? Groningen: Europa Law Publishing

Petithomme M. (2011). Awakening the sleeping giant? The displacement of the partisan cleavage and the change in government-opposition dynamics in EU referendums, in Perspectives on European Politics and Society, 12:1, 89-110

Pettai V., Madise U. (2006). The Baltic parliaments: Legislative performance from independence to EU accession, in Journal of Legislative Studies, 12, 3:4, 291-310

Piedrafita S. (2014). The Spanish parliament and EU affairs in the post Lisbon Treaty era: all change?, in the Journal of Legislative Studies, 20:4, 451-472

Pierre J., Svåsand L., Widfeldt A. (2000). State subsidies to political parties: Confronting rhetoric with reality, in West European Politics, 23:3, 1-24

Pierson P. (2000). Increased returns, path dependence and the study of politics, in the American Political Science Review, 94:2, 251-267

Pochet P. (2003). Pensions: The European debate, in Clark G.L. and Whiteside N. (eds) Pension security in the $21^{\text {st }}$ century. Redrawing the public-private debate. Oxford, N.Y.: Oxford University Press

Pochet P., Natali D. (2005). Reseaux europeens relatifs aux pensions: la participation d'ínterets organizes au processus decisionnel de lÚE, in Revue belge de securité social, 2, 307-335

Poguntke et al. (2007). The Europeanisation of national party organizations, A conceptual analysis, in European Journal of Political Research, 46:6, 747-771

Pollak J., Slominski E. (2003). Influencing EU politics? The case of the Austrian parliament, in Journal of Common Market Studies, 41:4, 707-729

Polsby N. (1975). Legislatures, in Greenstein F., Polsby N. (eds). Handbook of Political Science. Reading, Mass.: Addison-Wesley

Princen S., Kerremans B. (2008). Opportunity structures in the EU multi-level system, in West European Politics, 31:6, 1129-1146

Rasch B.E., Tsebelis G. (2010). The role of governments in legislative agenda-setting. N.Y. Routledge

Raunio T. (1999). Always One Step Behind? National Legislatures and European Integration, Government and Opposition., 34:2, 180-202

Raunio T. (2002). Why European integration increases leadership autonomy within political parties, in Party politics, 8:4, 405-422

Raunio T. (2005a). Much ado about nothing? National legislatures in the EU Constitutional Treaty, in European Integration online Papers (EIoP), 9, 9

Raunio T. (2005b). Holding governments accountable in European Affairs: Explaining cross-national variation, in Journal of legislative Studies, 11:3-4, 319-342

Raunio T. (2009). National parliaments and European Integration. What we know and what we should know, in ARENA Working Paper, 2/2009

Raunio T. (2011). The gatekeepers of European integration? The functions of national parliaments in the EU political system, in Journal of European integration, 33:3, 303-321

Raunio T., Wiberg M. (2000). Does support lead to ignorance? National parliaments and the legitimacy of EU governance, in Acta Politica 35:2, 146-168

Raunio T., Wiberg M. (2010). How to measure the Europeanisation of a national legislature, in Scandinavian political studies, 33:1, 74-92

Raunio T., Wright A. (2006). Holyrood and Europe: an incremental response to deparliamentarisation, in Regional and Federal studies, 16:3, 281-296 
Ray L. (1999). Measuring party orientations towards European integration: Results from an expert survey, in European Journal of Political Research, 36:2, 283-306

Richards D. (1996). Elite interviewing: Approaches and Pitfalls, in Politics, 16:3, 199-204

Riekmann S.P., Wydra D. (2013). Representation in the European State of Emergency: parliament against governments?, in Journal of European integration, 35:5, 565-582

Ritchie J., Lewis J., Elam G. (2003). Designing and selecting samples, in Ritchie J., Lewis J.(eds). Qualitative research in practice. A guide for social science students and researchers. SAGE: Thousand oaks

Rizutto, F. (2003). National parliaments and the European Union: part of the problem or part of the solution to the democratic deficit in the European constitutional settlement, in Journal of legislative studies, 9:1, 87-109

Rizutto F. (2004). European integration and the French parliament: From ineffectual watchdog to constitutional rehabilitation and an enhanced political role, in Journal of Legislative Studies, 10:1, 123-149

Rohlfing I. (2012). Case studies and causal inference. An integrative framework. N.Y.: Palgrave

Romaniello M. (2013). Beyond the constitutional "bicameral blueprint": Europeanization and national identities in Belgium, in Cartabia M., Lupo N., Simoncini A. (eds) Democracy and subsidiarity in the EU. National parliaments, regions and civil society in the decision-making process. Società editrice il Mulino: Bologna

Rometsch, D., Wessels, W. (eds) (1996). The European Union and the member-states: Towards institutional fusion? Manchester: Manchester University Press

Rothenberger S., Vogt O. (2007). The “orange card”: a fitting response to national parliaments' marginalization in EU decision-making? Paper prepared for the Conference "Fifty years in inter-parliamentary cooperation", 13 June 2007, Bundesrat, Berlin

Rozenberg O. (2002). The involvement of national parliaments in the European Union affairs. An empirical test of two variables. Paper for the ECPR Joint Session of Workshops. Turin

Rozenberg O. (2009). Présider par plaisir. L'examen des affaires européennes à l'Assemblée nationale et à la Chambre des Communes depuis Maastricht, Revue française de science politique, 59:3, 401-427

Rubin H., Rubin J. (2005). Qualitative interviewing: the art of hearing data. L.: SAGE publications

Ruin O. (2000). The Europeanization of Swedish Politics, in Miles L. (ed). Sweden and the European Union evaluated. L., N.Y.: Contimium

Saalfeld T. (2005). Deliberate delegation or Abdication? Government backbenchers, ministers and European Union legislation, Journal of legislative studies, 11:3-4, 343-371

Sandri G., Pauwels T. (2010). Party membership role and party cartelization in Belgium and Italy: Two faces of the same medal?, in Politics and Policy, 38:6, 1237-1266

Scarrow S. (2006). Party subsidies and the freezing of party competition: Do cartel mechanisms work?, in West European Politics 29:4, 619-639

Schäfer A., Roth M., Thum C. (2007). Stärkung der Europatauglichkeit des Bundestages, in Integration, 1:7, 44-49

Scharpf F. (1999). Governing in Europe. Effective and Democratic? Oxford: Oxford University Press

Schmidt V. (2006). Democracy in Europe. The EU and national polities. Oxford, Oxford University Press

Schmidt V. (2009). Comparative institutional analysis, in Landman T., Robinson N. (eds.) The SAGE handbook of Comparative Politics. SAGE: L.

Schofield J. (2000). Increasing the generalizability of qualitative research, in Gomm R., Hammersley M., Fioster P. (eds.) Case study method. Key issues, Key texts. SAGE: L.

Schrader N. (2010). Offene Koordinierung in der EU Rentepolitik, in Aus Politik und Zeitgeschichte, $18 / 2010$

Schroth J. (2010). Czech Republic, in Migration, employment and labour market integration policies in the European Union. Part I: Migartiona nd Labour markets in the European Union (2000-2009). IOM, LINET: Brussels

Schuldi M. (2005). The reform of the Bismarckian pension systems: a comparison of pension politics in Austria, France, Germany, Italy and Sweden. Amsterdam: Amsterdam University Press

Scoffoni G. (1992). Les relations entre le Parlement européen et les parlements nationaux et le renforcement de la légitimité démocratique de la Communauté, in Cahier du Droit Européen, 1:2, 22-41 
Seawright J., Gerring J. (2008). Case selection techniques in case study research: A menu of qualitative and quantitative options, in Political Research Quarterly, 61:2, 294-308

Selen J., Ståhlberg A.-C. (2007). Why Sweden's pension reform was able to be successfully implemented, in European Journal of Political Economy, 23:4, 1175-1184

Shaw M. (1998). Parliamentary committees: a global perspective, in Journal of Legislative Studies, 4:1, 225 251

Shepsle K. (2002). Assessing comparative legislative research, in Loewenberg L., Squire P., Kiewiet D. (eds). Legislatures. Ann Arbor, MI: Michigan University Press

Shepsle K., Weingast B. (1981). Structure-induced equilibrium and legislative choice, in Public choice, 37:3, 503-519

Sieberer U. (2011). The institutional power of Western European Parliaments: A multidimensional analysis, in West European Politics, 34:4, 731-754

Slagter T. H. (2009). National parliaments and the ECJ: A view from the Bundestag, in Journal of Common Market Studies, 47:1, 175-197

Sleath W. (2007). The role of national parliaments, in Amato G., Bribosia H., de Witte B. (eds) Genesis and destiny of the European Constitution. Bruxelles: Bruylant

Smith E (ed). (1996). National parliaments as cornerstones of European integration. L.: Kluwer Law International

Soare S. (2012). The Romanian party system's Europeanisation: an open bet, in Külahci E. (ed.) Europeanisation and party politics. How the EU affects domestic actors, patterns and systems. ECPR press

Spanihelova L., Zicha B. (2012.) Party responsiveness on European Union integration in transition democracies of Central and Eastern Europe, in Journal of Common Market Studies, 50:5, 764-782

Sousa M. (2008). Learning in Denmark? The case of Danish parliamentary control over European Union policy, in Scandinavian Political Studies, 31:4, 428-447

Sprungk C. (2010). Even more or better scrutiny? Analysing the conditions of effective national parliamentary involvement in EU affairs. European Integration online Papers (EIoP), 14:2

Sprungk C. (2011). How policy-shaping might (not) affect policy-taking: the case of national parliaments in the European Union, in Journal of European Integration, 3:3, 323-340

Sprungk C. (2013). Legislative transposition of directives: Exploring the other role of national parliaments in the European Union, in the Journal of Common Market Studies, 51:2, 298-315

Stephenson P. (2009). Catching the train to Europe: executive control of policy formulation inside Spain's parliamentary European Affairs Committee, in South European Societies and Politics, 14:3, 317-336

Strøm K. (1998). Parliamentary committees in European democracies, in Journal of Legislative Studies, 4:1, 21-59

Stuchlik A., Buzogany A. (2011). Paved with good intentions: Ambiguities of empowering parliaments after Lisbon. Paper for UACES conference "Lisbon Treaty evaluated". London, 31 January

1 February

Szalay K. (2005). Scrutiny of EU affairs in the national parliaments of the new member states comparative analysis. Budapest: Hungarian National Assembly

Szczerbiak A., Taggart P. (eds). (2008). Opposing Europe? The comparative party politics of Euroscepticism. Vol.2: Comparative and Theoretical perspectives. Oxford: Oxford University Press

Taggart P., Szczerbiak A. (2013). Coming in from the cold? Euroscepticism, government participation and party positions on Europe, in Journal of Common Market Studies, 51:1, 17-37

Tanchev E., Peteva J. (2006) Bulgaria, in Kellerman A. E. et al (eds) The impact of EU accession on legal orders of new EU member states and (pre-) candidate countries. Hopes and fears. The Hague: T.M.C.Asser Institute

Tans O. (2006). The Dutch parliament and the European Constitution, in in Verhey L., Kiiver P., Loeffen S. (eds.) Political accountability in Europe: Which way forward? Groningen: Europa Law Publishing

Tans O., Zoethout C., Peters J. (eds) (2007). National parliaments and the European Union: a bottom-up approach to European constitutionalism. Groningen: Europa law Publishing

Tansy O. (2007). Process tracing an elite interviewing: a case for non-probability sampling, in Political Science and Politics, 40:4, 765-772 
Töller A. (2006). How European integration impacts on national legislatures: The Europeanization of the German Bundestag. Center for European Studies Program for the Study of Germany and Europe. Working Paper Series 06.2

Töller A. (2010). Measuring the Europeanization of public policies Journal of Common Market Studies, 48:2, 417-444

Toma C. (2004). The collection of pension contributions in Romania, in Fulz E., Stanovnik T. (eds). The collection of pension contributions: Trends, issues and problems in Central and Eastern Europe. Budapest: International Labour Organisation

Tsakatika M. (2007). A parliamentary dimension for EU soft governance, in Journal of European Integration, 29:5, 549-564

Uebelmesser S. (2004). Unfunded pension systems: Ageing and migration. Amsterdam: Elsevier

Van Biezen I., Rashkova E. (2011). Breaking the cartel: The effect of state regulation on new party entry, in Party law in modern Europe Working paper №12

Van den Berge M. (2014). The 2014 EP election campaign in the member states: national debates, European elections. TEPSA report

Van der Eijk C., Franklin M. (2004). Potential contestation on European matters at national elections in Europe, in Marks G., Steenbergen M.R. (eds) European Integration and Political conflict. Cambridge: Cambridge University Press

Van der Schyff G., Leenkneger G.-J. (2007). The case for a European Senate. A model for the representation of national parliaments in the European Union, in Zeitscheift für öffentliches Recht (ZÖR) 62

Van Meerten H., Starink B. (2011). Cross-border obstacles and solutions for Pan-European pensions, in EC Tax Review, 20:1, 30-40

Van Meurs W.(2009). Romania: New membership and old habits?, in Südosteuropa. Zeitchrift für Politik und Gesellchaft, 2:3, 284-304

Van Vliet O. (2010). Divergence and Convergence: Europeanization of Social and Labour Market Policies, in Journal of European Integration, 32:3, 269-290

Vanhercke B. (2006). Variation of institutionalization of hybrid social protection OMC's: the choice for nonconstitutionalisation and the emergence of "hard soft law". Paper presented at the 2006 EPSANET conference. Bremen, 21-23 September 2006

Vanhercke B. (2009). Against the odds. The Open Method of Coordination as a selective amplifier for reforming Belgian pension policies, in European Integration online Papers (EIoP), 13:s1

Vavrejnová M., Belabed E., Wörister K. (2004). Pension reform in the Czech Republic: present situation and future prospects (a comparison with Austria), in Prague economic papers, 3/2004

Venesson P. (2008). Case studies and process tracing: theories and practices., in della Porta D., Keating M. (eds) Approaches and Methodologies in the Social Sciences. A pluralist perspective. Cambrdidge: Cambrdige University Press

Vignaux E. (2008). Cartelisation ou hybridation? Le case de Scandinavie, in Aucante Y., Dézé A. (eds). Les systèmes de parties dans les démocraties occidentals. Le modèle du parti-cartel en question. Sciences Po Les Presses: Paris

Von dem Berge B., Poguntke T. (2013). The influence of Europarties on central and East European partner parties: a theoretical and analytical model, in European Political Science Review, 5:2, 311-334

Von Ondarza N. (2012). Legimatoren ohne Einfluss? Nationale parlamente in Entscheidungsprozessen zu militärischen EU und VN Operationen in Vergeleich. Nomos Verlag: Baden-Baden

Wallace H. (2005). An institutional anatomy and five policy modes', in Wallace P., Wallace W., Pollack M.A. (eds). Policy-making in the European Union. $5^{\text {th }}$ ed. Oxford: Oxford University Press

Weber-Panariello P. (1995). Nationale parlamente in der Europäischen Union. Baden-Baden, Nomos

Wehner A. (2006). Assessing the power of the purse: an index of legislative budget institutions, in Political studies, 54:4, 767-785

Weiss R. (1994). Learning from strangers. The art and method of qualitative interviewing. N.Y.: The Free Press

Wendler F. (2012). What drives the politicization of European affairs. Paper presented for the ECPR Standing Group on the EU conference, 13-15 September 2012, Tampere, Finland 
Wessels B. (2005). Roles and orientations of members of parliament in the EU context: Congruence or difference?, in Journal of legislative studies, 11:3-4, 446-465

Wessels W., Rozenebrg O. et al. (2013). Democratic control in the member states of the European Council and the Euro zone summits. European Parliament. Directorate General for Internal Policies. $\mathrm{IP} / \mathrm{C} / \mathrm{AFCO} / \mathrm{IC} / 2012-012$

Wessels B., Katz R. (1999). (eds). European Parliament, national parliaments and European integration. Oxford, Oxford University Press

Westlake M. (1995). The European Parliament, the national parliaments and the 1996 Inter-governmental Conference, in The Political Quarterly, 66:1, 59-73

Whitaker R.(2005). National parties in the European Parliament: An influence in the committee system?, in European Union Politics, 6:5, 5-28

Wiberg M. (1997). Trying to make democracy work. The Nordic parliaments and the European Union. Stockholm: Gidlunds Förlag

Willumsen D., Öhberg P. (2012). Explaining legislative dissent t in a parliamentary party democracy: Sweden 2002 to 2011. Paper presented for the 2012 APSA Annual Meeting, New Orleans

Winzen T. (2011). Technical or political? An exploration of the work of officials in the committees of the European Parliament, in Journal of Legislative Studies, 17:1, 27-44

Winzen T. (2012). National parliamentary control of the European Union Affairs: a cross-national and longitudinal comparison, in West European politics, 35:3, 657-672

Winzen T. (2013). European integration and national parliamentary oversight institutions, in European Union Politics, 14:2, 297-323

Winzen T., Roederer-Rynning C., Schimmelfennig F. (2014). Parliamentary co-evolution: national parliamentary reactions to the empowerment of the European Parliament, in Journal of European Public Policy, 22:1, 75-93

Woolfson C., Olsson P., Thörnqvist C. (2012). Forced labour and migrant berry-pickers in Sweden, in The international journal of comparative labour law and industrial relations, 28:2, 147-176

Wouters J., Raube K. (2012). Europe's common security and defense policy: The case for inter-parliamentary scrutiny. Leuven Center for Global Governance Studies. Working Paper №.90

Zaidi A., Greech A.G., Fuchs M. (2006). Pension policy in EU 25 and its possible impact on elderly poverty. LSE Center for Analysis of Social Exclusion (CASE). Working Paper № 116

Zajc D. (2007). Slovenia's National Assembly, 1990-2004, in Journal of Legislative Studies, 13:1, 83-98

Zanon F. (2010). EU foreign policy cooperation: A challenge for national parliaments?, in European Foreign Affairs Review, 15:1, 19-38

Zehnpfund O., Rhombeerg A. (2009). Parlamentarische Mitwirkung in Angelegenheiten der Europäischen Union in Dänemark, Frankreich, Österreich, Polen, Tschechien und im Vereinigten Königreich. Deutscher Bundestag. Wissenschaftliche Dienst

Zier M. (2005). Nationale Parlamente in der EU. Göttingen: V \& R unipress GmbH

Zimmerling R. (2005). Influence and power. Variations on a messy theme. Dodrecht: Springer

Zubek R. (2011). Negative agenda control and executive-legislative relations in East Central Europe, 19972008, in Journal of Legislative Studies, 17:2, 172-192

Zuckerman H. (1972). Interviewing an ultra-elite, in The Public Opinion Quarterly, 36:2, 159-175 


\section{ANNEX 1: List of respondents ${ }^{267}$}

\section{Brussels}

B1a Representative of the Romanian Chamber of Deputies, 10.11.2010

B1b Representative of the Romanian Chamber of Deputies, 27.09.2011

B2a Representative of the Romanian Senate, 12.11.2010

B2b Representative of the Romanian Senate, 07.10.2011

B2c Representative of the Romanian Senate, 10.04.2012

B3 Representative of the Danish Parliament, 18.11.2010

B4 Representative of the Latvian Seimas, 10.11.2010

B5 Representative of the French National Assembly, 02.12.2010

B6a Representative of the Czech Chamber of Deputies, 02.12.2010

B6b Representative of the Czech Chamber of Deputies, 13.10.2011

B6c Representative of the Czech Chamber of Deputies, 20.06.2012

B7 Representative of the Dutch Tweede and Eerste Kamer, 12.11.2010

B8 Interview with an expert of the European Social Observatory, 06.10.2011

B9 member of DG EMPL, 12.10.2012

B10 member of DG ECFIN, 12.10.2012

B11 member of DG MARKT, 12.10.2012

B12 member of the Migration Policy Institute, short telephone interview, 28.09.2011

B13 member of DG Home Affairs, 06.10.2011

B14 member of the European Trade Union Confederation (ETUC), 23.09.2011

B15 shadow rapporteur on the Proposal for directive on seasonal labour migrants, Greens/EFA, 30.09.2011

B16a Representative of the Czech Senate, 16.11.2010

B16b same respondent, after moving to another position, 26.06.2012

B17 assistant to a Swedish MEP, 17.10.2011

B18 member of the EP Secretariat-General, 16.09.2011

B19a assistant of an MEP rapporteur (EPP) on the Green Paper on pensions, 23.09.2011

B19b assistant of an MEP (EPP) rapporteur on the White Paper on pensions, short telephone interview, 05.04.2012

B20 assistant of an S \& D shadow rapporteur on the Green Paper on pensions, short telephone interview, 14.10.2011

B21 assistant to a Greens/EFA shadow rapporteur on the Green Paper on pensions, short telephone interview, 23.09.2011

B22 assistant of ALDE group shadow rapporteur on the seasonal labour migrant directive, 07.10.2011

B23 assistant of the GUE/NGL shadow rapporteur on seasonal labour migration directive in the LIBE committee, 26.09.2011

B24 assistant of the S \& D rapporteur on the seasonal labour migrant directive in LIBE committee, 29.09.2011

B25 assistant of the S \& D rapporteur on the seasonal labour migrant directive in the EMPL committee, 14.10.2011

B26 member of ETUC, 07.10.2011

B27 representative of BusinessEurope, short telephone interview, 26.09.2011

${ }^{267}$ Reference is made to the position of a respondent at the time of the interview 
B28 representative of the Czech Senate, 31.05.2012

B29 representative of the Czech confederation of industry, 22.09.2011

B30 staff member of the Permanent Representation office of Sweden, 06.10.2011

R31 staff member of the Permanent Representation office of Romania, 28.11.2012

B32 staff member of the European Commission Secretariat-General, 02.07.2012

B33 staff member of the Permanent Representation of the Czech Republic, 19.10.2011

B34 staff member of a migration NGO, PICUM, 26.06..2012

B35 Romanian MEP, EPP party group, 23.11.2011

B36 Czech MEP, ECR party group, EMPL committee, Response to electronic questionnaire, 25.11.2011

B37 assistant to the GUE/NGL shadow rapporteur on seasonal labour migrants in the EMPL committee, 28.11.2011

B38 Czech MEP, EPP party group, IMCO committee, Response to electronic questionnaire, 10.10.2011

B39a Representative of the Swedish Riksdag, 06.11.2012

B39b Representative of the Swedish Riksdag (short phone interview), 11.10.2013

\section{Sweden}

S1 Left Party, member of the Social Insurance committee, 14.03.2012

S2a two members of the Social Insurance committee staff (joint interview), 06.03.2012

$\mathrm{S} 2 \mathrm{~b} \quad \mathrm{staff}$ member of the Social Insurance committee (response to a questionnaire), 30.09.2013

S3 staff member of the Riksdag, 13.03.2012

S4 staff member of the Riksdag, 13.03.2012

S5 political secretary, Green party in the Riksdag, 13.03.2012

S6a staff member of the Riksdag, 27.02.2012

S6b staff member of the Riksdag, second interview, 15.03.2012

S6c staff member of the Riksdag, third interview, 08.10.2013

S7 Centre party, member of the European Affair Committee, 29.02.2012

S8 Christian-Democratic party, member of the European Affairs Committee, 29.02.2012

S9 Liberal party, member of the European Affairs Committee, 12.03.2012

S10 Moderate party, member of the European Affairs Committee, 08.03.2012

S11a political advisor, Social-Democratic party, Riksdag, 02.03.2012

S11b same respondent, different position within the Social-Democratic party (phone interview), 25.11.2013

S12 senior staff member of the Riksdag, formerly involved with the EU issues, 07.03.2012

S13 political advisor, Moderate party, Riksdag, 06.03.2012

S14 representative of the SACO trade union, 08.03.2012

S15 representative of the Swedish pension agency, 14.03.2012

S16 expert on Swedish pension system, Stockholm University, 07.03.2012

S17 two experts on Swedish domestic politics, SIEPS, joint interview, 07.03.2012

S18 representative of the Swedish Migration Board, 09.03.2012

S19 journalist of the Svenska Dageblat, national newspaper, 28.02.2012

S20 expert on Swedish domestic politics, Uppsala University, 01.03.2012

S21 interviews with two representatives of the Swedish Confederation of Enterprise, 06.03.2012

S22 member of the EU coordination unit, Riksdag administration, 29.02.2012

S23 expert on the Swedish domestic politics, Stockholm University, 13.03.2012

S24 member of the Committee on Environment and agriculture, Left Party, 07.03.2012

S25 two members of the Swedish Ministry of Justice, joint interviews, 07.03.2012

S26 former staff member of the European Affairs Committee, 12.03.2012

S27 representative of the TCO trade union, 09.03.2012

S28a staff member of the European Affairs Committee, 13.03.2012

$\mathrm{S} 28 \mathrm{~b}$ responses of the European Affairs Committee staff member to a short questionnaire, 11.09.2012 
S29 Social-Democratic party, member of the European Affairs Committee, 06.03.2012

S30 pension journalist, Dagens Nyheter, national newspaper, 08.03.2012

S31 expert on Swedish domestic politics, Södertörn University, 05.03.20`12

S32 Social-Democratic party, member of the European Affairs Committee, 02.03.2012

S33 representative of the TCO trade-union, 28.02.2012

S34 former head of the European Affairs Committee, 12.03.2012

S35 staff member of the Committee on the Constitution, 27.02.2012

S36 Liberal party, member of the Social Insurance committee and of the Pension group

S37 member of the Dagens Industri editorial board, national newspaper, 27.02.2012

S38 former staff member of the European Affairs Committee, 02.10.2012

S39 former member of the Riksdag, 16.11.2012

S40 former staff member of one of Alliance coalition parties, 12.11.2013

\section{Czech Republic}

C1a expert on Czech domestic politics, Czech NGO, 10.05.2012

C1b expert on Czech domestic politics, Czech NGO, 17.05.2013

C2 staff member of the EU Unit, Czech Senate, 27.04.2012

C3 expert on Czech domestic politics, Charles University, 10.05.2012

C4 staff member of the Parliamentary Institute, Chamber of Deputies, 11.05.2012

C5 staff member of the Parliamentary Institute, Chamber of Deputies, 09.05.2012

C6 former member of the EU Unit, Czech Senate, 30.04.2012

C7a former member of the EU unit, Czech Senate, Brussels, 08.09.2011

C7b former member of the EU unit, Czech Senate, Brussels, 22.09.2011

C8a staff member of the EAC secretariat, Czech Senate, 07.05.2012

C8b staff member of the EAC secretariat, Czech Senate, 15.05.2013

C9 VV, member of the Chamber of Deputies European Affairs Committee, 04.05.2012

C10 former member of the EU Unit, Czech Senate, 25.04.2012

C11 ODS senator, member of the European Affairs Committee, 26.04.2012

C12 TOP09, member of the Chamber of Deputies, response to a questionnaire, 16.05.2012

C13 expert on Czech pension system, CERGE-EI think tank, 03.05.2012

C14 journalist, Praguepost, 11.05.2012

C15 IPEX correspondent of the Chamber of Deputies, 02.05.2012

C16a staff member of the Parliamentary Institute, Chamber of Deputies, 02.05.2012

C16b staff member of the Parliamentary Institute, Chamber of Deputies, 15.05.2013

C17 former staff member of the EU Unit, Czech Senate, 21.06.2012

C18 expert on Czech domestic politics, Charles University, 26.04.2012

C19 expert on migration issues, International Organization for Migration, 03.05.2012

C20 former member of the Senate European Affairs Committee secretariat, 03.05.2012

C21 representative of the Confederation of Industry of the Czech Republic, 10.05.2012

C22 former member of the Chamber of Deputies European Affairs Committee, Greens, 24.04.2012

C23 former member of the Parliamentary Institute, Chamber of Deputies, 09.05.2012

C24 pensions journalist, Lidove Noviny, national newspaper, 24.04.2012

C25 ODS party, member of the Senate European Affairs Committee, 03.05.2012

C26 expert on migration issues, Association for Integration and Migration, 30.04.2012

C27 staff member of the EU Unit, Czech Senate, 23.04.2012

C28 expert on Czech pension systems/social affairs, Charles University, 09.05.2012

C29 expert on Czech politics, Institute of International Politics, 23.04.2012

C30a expert on Czech politics, Institute of International Relations, 11.06.2012

C30b expert on Czech politics, Institute of International Relations, 15.05.2013

C31a staff member of the Parliamentary Institute, Chamber of Deputies, 25.04.2012 
C31b staff member of the Parliamentary Institute, Chamber of Deputies, 13.05.2013

C32 representative of the Czech-Moravian Confederation of trade unions (CMKOS), 24.04.2012

C33 representative of the KDU-ČSL party (Christian-Democratic party), 13.05.2013

C34 representative of the ODS party (Civic Democratic party), 16.05.2013

C35 staff member of the Chamber of Deputies' administration, 14.05.2013

C36 staff member of the EU Unit, EU Senate, 15.05.2013

C37 representative of the ČSSD (Czech Social-Democratic party), 16.05.2013

C38 representative of the TOP 09 party, digital response to the questionnaire, 21.05.2013

C39 staff member of the EU Unit, Czech Senate, 14.05.2013

\section{Romania}

R1a former staff member of the Chamber of Deputies, 17.11.2011

R1b former staff member of the Chamber of Deputies, 14.02.2012

R1c former staff member of the Chamber of Deputies, 24.05.2012

R1d former staff member of the Chamber of Deputies, 28.11.2013

R2 member of the European Affairs Committee, Romanian Chamber of Deputies, 02.04.2012

R3a expert on Romanian domestic politics, Friedrich Ebert Stiftung, 03.04.2012

R3b expert on Romanian domestic politics, Friedrich Ebert Stiftung, 14.10.2013

R4 expert on Romanian politics, European Institute of Romania, 09.04.2012

R5 former member of the presidential administration in charge of monitoring the activity of the Romanian parliament, 11.04.2012

R6 expert on Romanian politics, European Institute of Romania, 09.04.2012

R7 expert on Romanian politics, National School of political studies and public administration, 04.04.2012

R8a staff member of the Chamber of Deputies' European Affairs Committee, 06.04.2012

R8b staff member of the Chamber of Deputies' European Affairs Committee, 04.10.2013

R9 two staff member of the Directorate for Community law (Chamber of Deputies; joint interview), 09.04.2012

R10 expert on Romanian domestic politics, Bucharest University, 11.04.2012

R11 expert on Romanian domestic politics, Romanian Centre for European Policies, 05.04.2012

R12 staff member of the European Affairs Committee secretariat in the Senate, 05.04.2012

R13 two staff members of the "EU division" in the Senate administration (joint interview), 12.04.2012

R14 expert on Romanian politics, Essex University/CEU, 07.04.2012

R15 expert on Romanian politics, National School of political studies and public administration, 09.04.2012

R16 representative of a migration NGO, ADO SAH ROM, 11.04.2012

R17 representative of a migration NGO, ADO SAH ROM, 11.04.2012

R18a expert on Romanian politics, Free University of Brussels, 06.04.2012

R18b expert on Romanian politics (respondent moved to another academic job), 04.10.2013

R19 PNL, member of the Chamber of Deputies European Affairs Committee, 06.04.2012

R20 expert on Romanian social policy, Friedrich Ebert Stiftung, 13.04.2012

R21 representative of the Institute of Public Policy, Bucharest, 10.04.2012

R22 academic expert on Romanian politics, 05.10.2013 


\section{ANNEX 2: Questionnaire templates ${ }^{268}$}

\section{Questionnaire template 1: Members of European Affairs Committees (and sectoral committees)}

1. The Lisbon Treaty has introduced a number of new provisions dealing with national parliaments. In your opinion, how has the (specific parliament/chamber) adapted to them?

2. Do you see the support you receive from parliamentary staff/administration during the scrutiny of EU affairs as sufficient?

3. What has been the role of sectoral committees in scrutinizing the Green Paper on pensions and the Proposal for directive on seasonal labour migrants?

4. Did your party see the Green Paper / Proposal for a directive on seasonal labour migrants as an opportunity to change the national pension / labour migration regime?

5. Is the appointment of rapporteurs on EU affairs generally contested among political parties?

6. (For majority MP). Is your opinion on EU policies/Green Paper on pensions and Proposal for a directive on seasonal labour $\mathrm{m}$ Seasonal migrants directive in line with the one held by the government or not?

7. (For opposition MP). Do you think that the Lisbon Treaty has provided you with more opportunities to influence your respective government's EU policies?

Questionnaire template 2a: Parliamentary staff (secretariats of the European Affairs committee and sectoral committees, parliamentary experts and other members of parliamentary administrations)

1. Which tasks do you fulfil as a member of (respective secretariat)?

2. Have the tasks and working routine of the committee secretariat changed with the coming into force of the Lisbon Treaty?

3. How have you been involved in the scrutiny of the Green Paper on pensions/Proposal for directive on seasonal labour migrants?

Questionnaire template 2b: Parliamentary party secretariats

1. Now, more than 2 years since the entry into force of the Lisbon Treaty, can you say what kind of influence the Treaty has had on the inter-party relations in the (respective parliament)

2. To what extent are party secretariats engaged in the process of the EU affairs scrutiny?

${ }^{268}$ Probes and additional country-specific questions are not included. 
3. How often does it happen that the party you represent finds it hard to deliver a united opinion about an EU affairs issue?

4. How do you cooperate with the staff of sectoral/European affairs committees?

5. What are the main objectives of your party in terms of pension policy and labour migration?

Questionnaire template 3: Governmental officials

1. (Variant A) The European Commission has organized consultations on Proposal for directive on seasonal labour migrants. The directive was received with mixed feelings while the discussion at the EU level focused at the amount of social benefits and potential introduction of labour-market tests. What is the government's assessment of the EU proposal?

(Variant B) The European Commission has organized consultations on the Green Paper on pensions, which received very diverse views. It suggests increasing retirement age, developing occupational and private pension schemes, making pension assets increasingly more transferable in between countries. What is the view of the government towards this EU document?

2. Has this position been changed somehow during the process of scrutiny of these documents in the parliament?

3. Do the opinions of the government and opposition on these policy proposals align or diverge?

4. To what extent are the suggestions made by the EU compatible with the national pension policy and labour migration regime?

6. Would you agree that for some parties/key stakeholders these new EU proposals provide an incentive to reassess the respective national policies?

Questionnaire template 4a: Experts (national political systems)

1. What are the main current cleavages in (respective country) within domestic politics? Just for me as an outsider to get an idea.

2. How would you describe the relations between the parliament and the government since the last general elections?

3. In general, to what extent has the opposition been able to shape the content of domestic politics?

4. (for bicameral) How can you describe the relations between the upper and the lower chamber?

5. How can you describe the party system of (respective country) 
1. Being a member of academia is it sometimes hard to evaluate the day-to-day practical development of a policy. Hence, could you please elucidate what are the interests of key actors in field)? (specific policy

2. In your opinion, to what extent is the policy content of the Green/White Paper on pensions compatible with the current structure of (respective country) pension system?

3. Would you agree that potentially the EU pension policy suggestions can be used to reassess the national pension policy by some political parties or key stakeholders?

Questionnaire template 5: NGOs and stakeholders

1. (Variant A) The European Commission has organized consultations with stakeholders and civil society actors about the Proposal for directive on seasonal labour migrants. It was received with mixed feelings, while its assessment at the EU level focused at the amount of social benefits and potential introduction of labour-market tests. How do you evaluate the proposal for directive?

(Variant B) The European Commission has organized consultations with stakeholders and civil society actors about the Green Paper on pensions. It suggests increasing retirement age, developing occupational and private pension schemes, making pension assets increasingly more transferable in between countries. What is the view of your organization towards this EU document?

2. To what extent, in your opinion, are these proposals compatible with the national welfare and labour migration regimes?

3. Can the documents proposed by the European Union be used by some political parties and/or stakeholders to redress national policies in respective areas?

4. Have you had consultations with your national parliament or political parties about these two documents?

5. A number of stakeholders, for example PICUM \& SOLIDAR (migration) or AEIP (social security) have been active in developing contacts with the European Commission and the European Parliament. Has your organization done the same? 



\section{Samenvatting}

De Europese Unie heeft een grote invloed gehad op de nationale structuren van beleidsvorming. In feite heeft de Europese integratie de nationale regeringen versterkt ten koste van de nationale parlementen. Toch heeft het Verdrag van Lissabon de rol van nationale parlementen in het Europees besluitvormingsproces versterkt, bijvoorbeeld door hen een controlefunctie te geven inzake de overeenstemming van Europese wetgeving met het subsidiariteitsprincipe. Mijn onderzoek gaat ervan uit dat het Verdrag van Lissabon een nieuwe 'opportunity structure' voor de nationale parlementen heeft geschapen: Met hun nieuwe competenties krijgen nationale parlementen betere kansen om invloed op het Europese politieke beleid te oefenen. Het Verdrag van Lissabon heeft ook een impact op de verhoudingen tussen de (verschillende typen van) parlementaire actoren, omdat de nieuwe competenties tot herverdeling van middelen en machtposities kunnen leiden.

De centrale onderzoeksvraag is welke factoren het gedrag van de nationale parlementen in de post-Lissabon politieke omgeving bepalen.

Dit onderzoek analyseert het gedrag van de parlementen van Zweden, Tsjechje en Roemenië die respectievelijk sterke, middelsterke en zwakke parlementen vertegenwoordigen. Onderzocht wordt hoe de bovengenoemde parlementen met twee dossiers omgaan, namelijk het 'Groene Boek' over pensioenen (COM 2010 365) en het 'Voorstel voor een Gemeenschappelijke Procedure voor Toegang en Verblijf van Seizoenenarbeiders' (COM 2010 379).

Om effectief gebruik maken van de nieuwe competenties moeten nationale parlementen aan twee voorwaarden voldoen. Ten eerste moeten de commissies voor Europese zaken samenwerken met de commissies voor andere beleidsgebieden om zo de taken effectief te verdelen en toegang tot technische/specialistische informatie te krijgen. Ten tweede moeten de parlementaire partijen georiënteerd zijn op het vinden van overeenstemming, of in ieder geval de bereidheid tonen om compromissen te willen sluiten. Anders verwordt de inhoudelijke discussie over Europese zaken tot een ideologische strijd die weinig heeft te maken met de EU.

In tegenstelling tot de verwachtingen heeft de parlementaire staf in werkelijkheid weinig politieke invloed. Omdat parlementsleden in Zweden, Tsjechje en Roemenië relatief weinig belangstelling hebben voor Europese vragen is er ook weinig vraag naar inhoudelijke analyses van Europese wetsvoorstellen, hetgeen de parlementaire staf de mogelijkheid ontneemt om het besluitvormingsproces stelselmatig te beïnvloeden. In parlementen met sterke partijconflicten, bij voorbeeld in Tsjechje en Roemenië, politieke partijen proberen ook het werk van parlementaire staf te beïnvloeden.

Het gedrag van parlementaire commissies blijkt meestal door de politieke partijen te worden bepaald. Politieke partijen probeerden de autonomie van parlementaire commissies voor Europese zaken in te dammen door 'tweederangs' politici tot commissiele- 
den te benoemen. Deze politici moeten in het ideologische kader van hun partij blijven om kans te houden op een stijging binnen de partijhiërarchie. Dat betekent dat ze weinig aanleiding hebben om akkoorden te sluiten met politici van een andere ideologische afkomst. Deze tendens is duidelijk zichtbaar in parlementen van Zweden, Tsjechje en Roemenië.

In tegenstelling tot de een van de oorspronkelijke verwachtingen die aan het onderzoek ten grondslag lagen, konden politieke partijen in de post-Lissabon omgeving andere parlementaire actoren marginaliseren en hun invloed op het besluitvormingsproces in Europese zaken belemmeren. Politieke partijen deden door gebruik te maken van een of meer van de volgende mechanismen:

- Controle over de selectie door de parlementaire staf van documenten voor nader onderzoek en over de manier van informatie uitwisseling tussen parlementaire commissies;

- Controle over de nominatie van de leden van de commissie voor Europese zaken;

- Controle over de procedure voor de behandeling van Europese kwesties.

De houding tegenover de Europese Unie speelt geen grote rol in de nationale politiek van Zweden, Tsjechje en Roemenië. Dat kan de oorzaak zijn voor het 'neglect' van de inhoud van Europese wetvoorslagen. Niettegenstaande het feit dat parlementsleden hun verkiezingskansen kunnen vergroten door inhoudelijke discussies over Europese wetsvoorstellen te voeren, concentreren zij zich liever op subsidiariteitskwesties. Dit gaat zowel op voor Eurosceptische als voor pro-EU partijen. Bovendien vertonen regeringspartijen en oppositie hetzelfde gedragspatroon: ze concentreren zich op de competentie verdeling tussen de EU en lidstaten en gebruiken niet de parlementaire discussie over EU zaken om het nationale pensioenen- of migratiebeleid in de richting van hun eigen preferenties te dirigeren.

Deze tendens kan op de lange termijn problemen veroorzaken omdat de inhoudelijke politieke discussie over Europese zaken door maatschappelijke organisaties en bewegingen kunnen worden overgenomen. Als nationale parlementen niet méér waarde hechten aan de inhoudelijke discussie over Europese zaken, lopen ze het gevaar hun centrale positie in het nationale debat over de Europese Unie te verliezen. Dat kan zijn weerslag hebben op de ons vertrouwde modellen van een representatieve democratie. 


\section{Valorization addendum}

The insights of this thesis do not only contribute to academic research on European integration but are of high relevance for practitioners and society at large.

In the first place, the research helps practitioners identify and raise awareness about the challenges of parliamentary scrutiny of EU affairs.

\section{Implications of the research for Members of Parliament and administrative staff}

The research points us into the direction that it is very often it is the lack of interest in European affairs amongst MPs that constitutes the main challenge in improving effectiveness of the scrutiny process. Input from MPs is essential for assessing EU proposals; otherwise a parliament's response to EU initiatives can remain a formality. MPs from different ideological groups and from both strong and weak parliaments require more education and training in EU issues in order to fully grasp the interconnection between EU and domestic politics. Members of parliament do not only need technical knowledge about the EU in order make a contribution to the scrutiny process but must be in command of a foreign language. This seems to be problematic for a rather large number of MPs in Central and Eastern Europe. Obviously, offering language courses may be impractical due to financial reasons but hiring assistants with advanced language skills or establishing an extended corps of translators may help overcome this problem.

Secondly, the results of the thesis allow practitioners to consider different approaches to providing administrative support to the scrutiny process. Although parliamentary administrators are crucial for filtering incoming EU documentation, parliamentary chambers often do not have enough resources to conduct the analysis of EU proposals independently of domestic executives. This does not necessarily constitute a problem, yet this practice may raise concerns of the wider public about independence or bias of parliament's judgments. Better training, intensive networking with NGOs and academia, establishment of dedicated analytical units, - all these measures can help national parliaments be less dependent on governments for the assessment of EU proposals. This observation is especially relevant in light of the economic crisis, as parliaments are faced with a challenge of legitimizing harsh economic measures which may not be fully or adequately understood. Obviously, national parliaments do not need to provide alternatives to domestic or EU policy solutions just for the sake of presenting a different opinion. However, parliaments should have the ability to discuss technical and complex issues on equal terms with national governments as at the very end this helps ensure the adequacy of the decisions taken.

Thirdly, practitioners can find the dissertation useful as it provides information on 'best practices' of organizing parliamentary scrutiny of EU affairs. Academic analysis provides additional arguments for considering the applicability of specific 'best practic- 
es' in domestic contexts. For example, the practice established in the Swedish Riksdag, namely regular formalized contacts between the EAC and other sectoral committees could be used as a role model for parliaments in the Czech Republic and Romania, where such contacts have traditionally been much more ad hoc. The thesis provides additional supportive arguments for domestic parliamentary actors which lobby for more regular cooperation between EACs and sectoral committees. Moreover, the thesis highlights the benefits of a regular dialogue between MPs and members of the European Parliament. So far, such contacts remain rather ad hoc but the thesis shows the benefits of such a dialogue not only for networking but also for policy coordination and lobbying at the EU level. This academic assessment can serve as an additional argument for practitioners to synchronize MP-MEP activities and enhance collaboration with the European Parliament.

\section{Implications of the research for stakeholders and citizens}

Stakeholders at both domestic and EU levels will find the research results important for the set-up and conduct of their lobbying activities. Although at this moment national parliaments do not seem to be the focus of domestic or EU stakeholders aiming at promoting specific policy solutions in the domain of EU affairs, in the recent future this may well change due to more intensive inter-parliamentary dialogue and greater cooperation between domestic legislatures and the European Parliament. The two 'yellow cards' passed within the framework of the Early Warning System and an increasing number of sectoral policy dialogues between national parliaments and the EP mean that inter-parliamentary cooperation is likely to play an ever greater role in the EU political system. This offers new opportunities for various stakeholders to promote their policy preferences and develop new strategies of lobbying or interest representation.

Moreover, the research is of immediate interest not only for MPs and parliamentary staff, it addresses a highly salient topic which has direct impact upon all EU citizens. Parliaments are essential for representative democracy, one of the key founding values of the EU, and help ensure accountability of the decisions taken by politicians and their focus on the public good. However, accountability of decisions taken within the EU political system can be achieved only if parliamentary debates address the content of EU proposals and formal scrutiny rules are fully implemented in practice. The thesis shows that both of these conditions are often not met. Consequently, there is a greater risk that the decisions reached within the EU do not fully reflect voters' positions. In other words, the thesis highlights that the application of parliamentary scrutiny procedures in a number of EU member-states may not be fully in line with the principles of representative democracy.

This has a number of important implications for the citizens. On the one hand, they may stop considering national parliaments as an adequate arena for representing their attitudes towards the EU. On the other hand, citizens can increasingly rely on NGOs, social movements and other non-parliamentarian forms of political organization to ex- 
press their views towards the EU. Although these new forms of political activity can help distinct actors achieve their political goals, there may not be a specific arena where these sectoral interests can be reconciled as parliaments play an increasingly weaker role in steering public debates on EU topics.

This dialogue between politicians and citizens cannot be reduced to the abovementioned suggestions for practitioners, as they relate primarily to the set-up, support and conduct of the parliamentary scrutiny process. One requires an overhaul of relationship between MPs and voters in the domain of EU affairs, what cannot be addressed just by changing institutional design. Better communication between MPs and their electorates, reference to the EU in constituency service, educational programmes, - these can be the measures to help sustain parliaments as centers of national public debates on EU topics.

The practical relevance of research on national parliaments and European integration is clearly demonstrated by the event organized by the Observatory of Parliaments after the Lisbon Treaty (OPAL) at the Europe House in London in March 2014. The event was attended by a large number of prominent British MPs, members of the European Parliament as well as staffers from several national parliaments. This clearly shows that this type of research is considered relevant and important by political actors.

The results of the research have also been presented at a number of conferences and academic events: THESEUS doctoral seminar (Paris, 2012), OPAL conferences (Maastricht 2012; Berlin 2013), UACES student forum $13^{\text {th }}$ annual research conference (Brussels, 2012), $4^{\text {th }}$ ECPR Graduate student conference (Bremen, 2012), UACES $42^{\text {nd }}$ Annual conference (Passau, 2012), $6^{\text {th }}$ SGEU Pan-European conference on EU politics (Tampere, 2012). These events have been used not only to present and disseminate the results of the thesis in the academic audience but also to obtain feedback from practitioners, as, for example, delegates from the EP and the Czech Parliament were present at several of the abovementioned events. 



\section{Acknowledgments}

Writing a $\mathrm{PhD}$ has been an adventurous experience akin to a journey with no map. I knew where I started and I knew where I wanted to go but the distance between these two points remained terra incognita. I am very thankful to my supervisors, Tannelie Blom and Christine Neuhold, for their help along the way. I have learnt a lot from you. Dear Christine, thank you for giving me a chance to embark on this journey. Without you saying 'yes' in early 2010 it would not have happened. I am forever indebted. Dear Tannelie, thank you for commenting, reading and re-reading my work. Towards the end of my project you gave me your best advice. You suggested "falling in love with my text". This was exactly what I needed to motivate myself for yet another round of corrections. I would also like to express my deep gratitude to Sophie Vanhoonacker, who has always been very supportive and understanding.

I would like to thank all members of the OPAL (Observatory of Parliaments after the Lisbon Treaty) project, especially the Maastricht team, for a chance to be part of an international research community and receive valuable feedback. Anna-Lena, thanks for brainstorming and coffees at 'Banditos'.

A special 'thank you' goes to my interviewees, although they have to stay anonymous. Whether you had only 15 minutes or spared two hours, it was all appreciated. Without your collaboration and willingness to help this work would have not been possible. Andreea Nastase and Viorelia Gasca, thanks a lot for your help in translating Romanian documents where 'Google Translate' failed me.

My colleagues and office-mates made the $\mathrm{PhD}$ adventure more enjoyable. Thank you for putting up with me constantly drawing on the whiteboard, walking in circles and mumbling something about parliamentary scrutiny of EU affairs. Bart, Nataliia and Dirk had the most of it. I hope it was a pleasure for them as much as it was for me to share the same 'cave'. Maarten, thank you for explaining me what 'indie' and 'fandom' are as well as suggesting going to Efteling, an offer I keep refusing. Tjorven, thank you for proving me that cars can be exciting. Aneta, Heidi, Patrick, Ludek and all of the FASOS staff members - thank you for making these 4 years in Maastricht such a great enriching experience.

Moving to another country is always a challenge. I would like to thank Roeland and Marianne Tilly for helping me to find my way in the new environment. Yvonne, Sanne and Joost, thank you for introducing me to the Dutch language, I could not have wished for better teachers. Peter, thanks a lot for enlightening me about Dutch politics and correcting my sollicitatiebrieven.

My sister in all but name, Victoria, as well as Simon have been great friends. Without their moral support the first year in Maastricht would have been much more difficult. 
Ksenia and Leonid, although it has been years since you have left for a better world, you are still with me. I thank you for giving me courage and watching over me.

My parents, Tatyana and Alexander, words do not suffice to describe how grateful I am to have you. I am extremely lucky to have such parents. You believed in me and supported me when no one did. I would not have been able to go so far without you.

This thesis is not just my achievement; it is your success as well.

Yeliz, benim sevgilim, meeting you was a miracle. You brought so much colour and laughter into my world. Benim kısmetim, thank you for giving me strength, joy and happiness which helped me during writing and re-writing. I look forward to more ochos, cortados and media lunas in the years to come. 


\title{
Curriculum vitae
}

\begin{abstract}
Alexander Strelkov (1985) has studied politics at the Russian State University for the Humanities, Moscow, Freie Universität Berlin and Essex University. Since late 2006 he has been affiliated to the Institute of Europe, Russian Academy of Sciences, becoming a research fellow in 2008. His work focused on the EU's political conditionality, European Neighbourhood Policy and EU-Russia relations in the post-Soviet region. He has contributed to the Russian peer-reviewed journal World Economy and International Relations. In May-June 2010 he has been a visiting research fellow at KU Leuven, benefiting from the Chair InBev Baillet-Latour grant. Alexander's work addressed the instruments of Russian and EU 'soft power' in Belarus and Ukraine. Between October 2010 and late September 2014 he has been a PhD candidate at the Maastricht University, working on the issue of parliamentary scrutiny of EU affairs. Alexander has also been an associate member of the OPAL (Observatory of Parliaments after the Lisbon Treaty) project dedicated to national parliaments and European integration. The results of his $\mathrm{PhD}$ project are published in West European Politics as well as in the Palgrave Handbook of National Parliaments and the European Union.
\end{abstract}




$$
\begin{aligned}
& \text { tareat of tomae exts } \\
& \text { party cartel wotes } \\
& \text { ectegt follticel clearese } \\
& \text { edacts commorectaife } \\
& \text { Bareat } \\
& \text { opportaeity otraetare } \\
& \text { atreat of } 1 \text { tes } \\
& \text { tited clearete } \\
& \text { reties } \\
& \text { epportastiz }
\end{aligned}
$$

Aes:

ectes

e equts

golttigel aleavese

Garees of tesa 